VILNIAUS GEDIMINO TECHNIKOS UNIVERSITETAS

Loreta KELPŠIENE

\title{
STATYBOS MODELIAVIMAS \\ EKONOMINIO NUOSMUKIO APLINKOJE
}

DAKTARO DISERTACIJA

TECHNOLOGIJOS MOKSLAI, STATYBOS INŽINERIJA (02T) 
Disertacija rengta 2007-2011 metais Vilniaus Gedimino technikos universitete.

\section{Mokslinis vadovas}

prof. habil. dr. Artūras KAKLAUSKAS (Vilniaus Gedimino technikos universitetas, technologijos mokslai, statybos inžinerija - 02T).

http://leidykla.vgtu.lt

VGTU leidyklos TECHNIKA 1884-M mokslo literatūros knyga

ISBN 978-9955-28-867-1

(C) VGTU leidykla TECHNIKA, 2011

(C) Loreta Kelpšienè, 2011

l.kelpsiene@tf.su.lt 
VILNIUS GEDIMINAS TECHNICAL UNIVERSITY

Loreta KELPŠIENÉ

\section{CONSTRUCTION MODELLING IN ENVIRONMENT OF ECONOMIC RECESSION}

DOCTORAL DISSERTATION

TECHNOLOGICAL SCIENCES, CIVIL ENGINEERING (02T) 
Doctoral dissertation was prepared at Vilnius Gediminas Technical University in 2007-2011.

\section{Scientific Supervisor}

Prof Dr Habil Artūras KAKLAUSKAS (Vilnius Gediminas Technical University, Technological Sciences, Civil Engineering - 02T). 


\section{Reziumè}

Pirmajame disertacijos skyriuje analizuojama statybos kaip ūkio šakos ir statybos kaip verslo srities sampratos. Apibendrinami atlikti patirties statybos versle bendro ekonominio nuosmukio aplinkoje moksliniai tyrinèjimai, nagrinèjami reagavimo į sudètingą ekonominę aplinką būdai.

Antrajame skyriuje nagrinejama statybos projekto igyvendinimo ekonominio nuosmukio aplinkoje modelio koncepcija. Aptariamas valstybès politikos vaidmuo statybos ekonomikai Lietuvoje ir užsienyje. Pateikiamas ir detaliai analizuojamas statybos, esant bendriems ekonomikos sunkumams, koncepcinis modelis, nagrinejjami modeli sudarantys elementai, nagrinejjami statybos projektą itakojantys veiksniai, mikro-, mezo- ir makroaplinka, jos itaka, rinkos charakteristikos, praktinès modelio realizavimo galimybès.

Trečiajame skyriuje atliekamas statybos projekto ekonominio nuosmukio aplinkoje variantinis projektavimas ir daugiakriterinė analizè. Sprendžiami praktiniai uždaviniai naudojant pasiūlytą modeli.

Ketvirtajame skyriuje pateikiama rekomendacinè statybos ekonominio nuosmukio aplinkoje sistema. Siame skyriuje detaliai aprašytos sistemos sudedamosios dalys: vartotojo sąsaja, duomenų bazès moduli sudarančios duomenų bazės ir modelių bazę sudarantys modeliai. Aiškinamas sistemos veikimo principas, pateikiami išspręsti praktiniai uždaviniai.

Pagrindiniai disertacinio darbo teiginiai buvo paskelbti 5 mokslinèse publikacijose ir aptarti tarptautiniame koliokviume (The 12th German-LithuanianPolish Colloquium „Sustainable Development in Civil Engineering and MultiAttribute Decision Making“ May 20-24, 2009 Vilnius, Lithuania) bei tarptautinejje konferencijoje (International Young Scientists Conference, 29-30 April 2010, Siauliai, Lithuania). 


\section{Abstract}

The thesis is divided into four chapters including the conclusion's chapter.

Chapter 1 of the dissertation analyses the concepts of construction as an industry and construction as business. It also summarises scientific research of construction business practices in times of general economic recession and looks into ways to react to complex economic settings.

Chapter 2 analyses the concept of the model of construction projects in environment of economic recession. It also discusses the impact of national policies on the construction sector in Lithuania and abroad. The model of construction in environment of general economic distress is presented and analysed in detail, also the model's components, factors affecting a construction project, micro, meso and macro-environment, its influence, market features, and possibilities to implement the model in practice.

Chapter 3 involves multi-variant design and multiple criteria analysis of a construction project in environment of economic recession. The suggested model is used to solve practical problems.

Chapter 4 describes the recommendable system for construction projects in environment of economic recession. The chapter details the system's components: the user interface, the databases in the database module and the models in the model base. The chapter also explains the system's principle of operation and describes practical problems that were solved.

The main propositions of the dissertation were published in 5 scientific articles and discussed in an international colloquium (The 12th German-LithuanianPolish Colloquium „Sustainable Development in Civil Engineering and MultiAttribute Decision Making“. May 20-24, 2009 Vilnius, Lithuania) and an international conference (International Young Scientists Conference, 29-30 April 2010, Šiauliai, Lithuania). 


\section{Žymèjimai}

\section{Simboliai}

$D$ - pradinè sprendimų prièmimo matrica;

$d_{i j}$ - bedimensès įvertintos kriterijų reikšmès;

$m$ - kriteriju skaičius;

$N_{j}$ - naudingumo laipsnis;

$n$ - lyginamų variantų skaičius;

$S_{+j}-$ maksimizuojančiu ivertintų normalizuotų rodiklių suma;

$S_{-j}$ - minimizuojančių i̇vertintų normalizuotų rodiklių suma;

$Q_{j}$ - santykinis alternatyvos reikšmingumas;

$q_{i}-i$ kriterijaus reikšmingumas;

$x_{i}-i$ kriterijus;

$x_{i j}-i$ kriterijaus reikšmè $j$ sprendimo variantu. 


\section{Santrumpos}

$\mathrm{AB}$ - akcinè bendrove;

$\mathrm{A} \$$ - Australijos doleris;

BPNN (angl. back-propagation neural networks) - atgalinio ryšio neuroniniai tinklai;

BVAR (angl. Bayesian vector autoregressive) - Bajeso vektorinė autoregresija;

BVP - bendrasis vidaus produktas;

CEER (angl. Construction in environment of economic recession) - statyba ekonominio nuosmukio aplinkoje;

DA - diskriminantinè analizé;

DNM - daugiabučių namų modernizacija;

ES - Europos Sajunga;

EWS (angl. Early warning systems) - išankstinio perspejjimo sistemos;

IEWS (angl. Integrated early warning system) - integruota ankstyvojo įspejimo sistema;

I/O (angl. Input output) - iejjimo / išèjimo sąsaja;

JAV - Jungtinès Amerikos Valstijos;

JK - Jungtinè Karalysté;

LR - Lietuvos Respublika;

NN (angl. Neural networks) - neuroniniai tinklai;

PVM - pridètinès vertès mokestis;

SENA - statybos ekonominio nuosmukio aplinka;

SVM (angl. Support vector machine) - pagrindinių komponenčiu mechanizmas;

VPSR - vilos ir parko statinių rekonstrukcija. 


\section{Turinys}

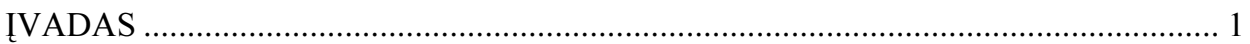

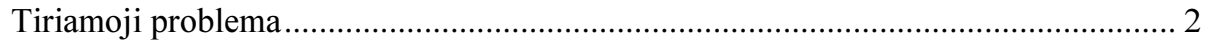

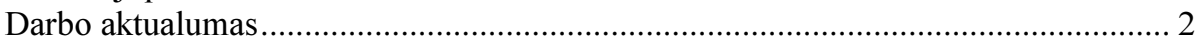

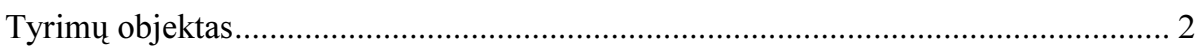

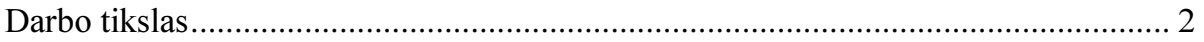

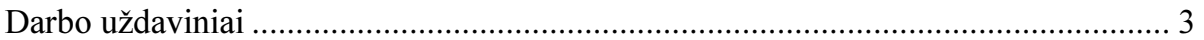

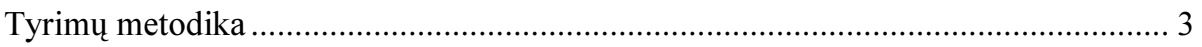

Darbo mokslinis naujumas ir jo reikšmè .............................................................. 3

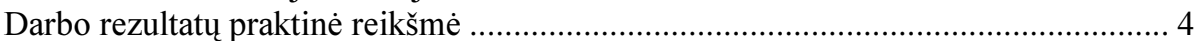

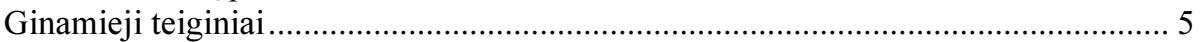

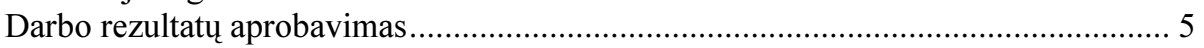

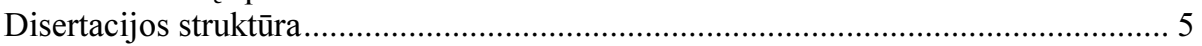

1. STATYBOS ŠAKA EKONOMINIO NUOSMUKIO SĄLYGOMIS LIETUVOJE IR

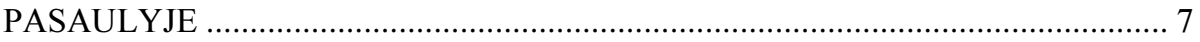

1.1. Išskirtiniai statybos kaip ūkio šakos bruožai ...................................................... 7

1.2. Statybos valdymo modeliai, metodai ir sistemos ............................................... 16

1.3. Imonès, dirbančios statybos srityje, veiklos elementai....................................... 22

1.4. Galimi reagavimo ị bendrą ekonominị nuosmukị būdai (patirtis) ...................... 25

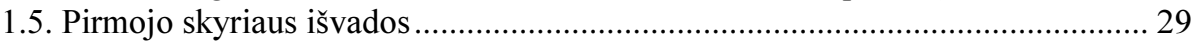

2. STATYBOS EKONOMINIO NUOSMUKIO APLINKOJE KONCEPCINIS

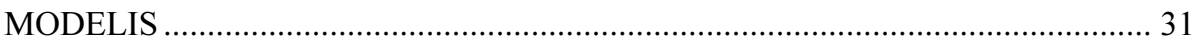

2.1. Statybos ekonominio nuosmukio aplinkoje modelio koncepcija......................... 31

2.2. Statybos ekonominio nuosmukio aplinkoje modelio elementų aprašymas ........ 33 
2.2.1. Makroveiksniai, darantys itaką statybai................................................. 33

2.2.2. Mezoveiksniai, darantys ịtaką statybai ................................................ 42

2.2.3. Mikroveiksniai, darantys ittaką statybai .................................................. 45

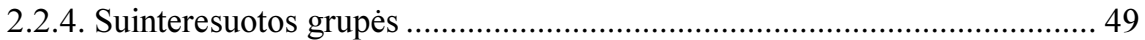

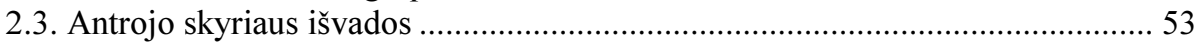

3. STATYBOS EKONOMINIO NUOSMUKIO APLINKOJE VARIANTINIS

PROJEKTAVIMAS IR DAUGIAKRITERINE ANALIZĖ .................................. 55

3.1. Daugiakriterinei analizei reikalingų pradinių duomenų rengimas ...................... 55

3.1.1. Daugiabučių namų modernizavimo projektų duomenys............................ 70

3.1.2. Nekilnojamojo kultūros paveldo objekto tęstinio projekto duomenys...... 72

3.2. Statybos ekonominio nuosmukio aplinkoje vertinimo kriterijų reikšmingumo nustatymas kompleksiniu metodu................................................................... 75

3.3. Statybos alternatyvų ekonominio nuosmukio aplinkoje vertinimas daugiakriterinio kompleksinio proporcingo ịvertinimo metodu .......................... 77

3.4. Skaičiavimo rezultatų palyginimas su atliktais TOPSIS metodu ......................... 82

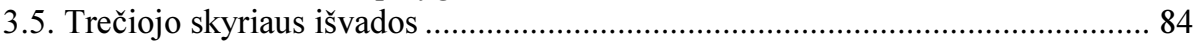

4. REKOMENDACINÉ STATYBOS EKONOMINIO NUOSMUKIO APLINKOJE

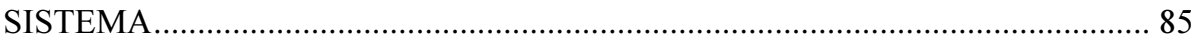

4.1. Rekomendacinės statybos ekonominio nuosmukio aplinkoje sistemos

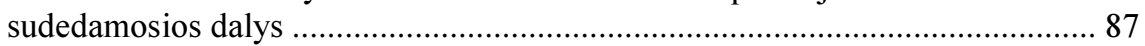

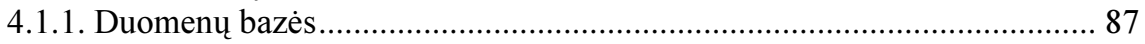

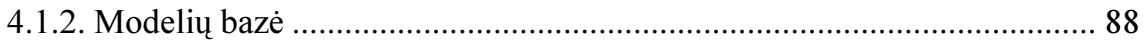

4.2. Statybos ekonominio nuosmukio aplinkoje daugiakriteriné analizè ir variantinis

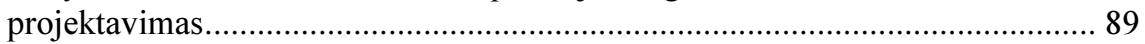

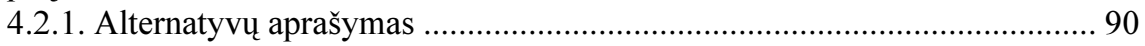

4.2.2. Statybos ekonominio nuosmukio aplinkoje sudètinių dalių daugiakriterinè

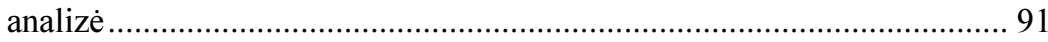

4.2.3. Statybos ekonominio nuosmukio aplinkoje variantinis projektavimas..... 93

4.2.4. Statybos ekonominio nuosmukio aplinkoje rekomendacijų pateikimas ... 95

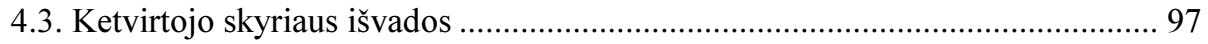

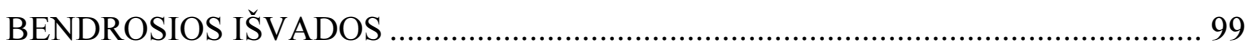

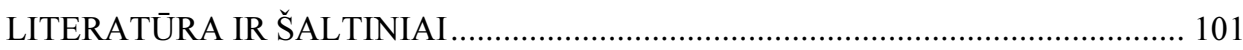

AUTORĖS PUBLIKACIJOS DISERTACIJOS TEMA........................................... 110

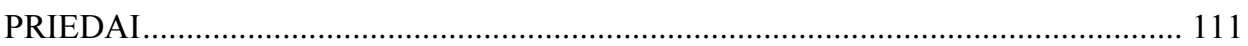

A priedas. Daugiabučių namų modernizavimo projektų igyvendinimo variantų kompleksinis kriterijų reikšmingumų nustatymas ............................................ 113

B priedas. Vilos parko ir statinių rekonstrukcijos igyvendinimo kompleksinis kriterijų reikšmingumų nustatymas ................................................................ 116

$\mathrm{C}$ priedas. Daugiabučių namų modernizavimo projektu igyvendinimo variantų daugiakriterinès analizès rezultatai .................................................................. 120

D priedas. Vilos parko ir statinių rekonstrukcijos igyvendinimo daugiakriterinès

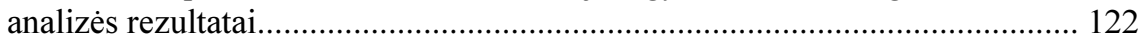

E priedas. Pakruojo dvaro sodybos restauravimo projekto duomenys .................... 125

F priedas. Devynaukščiu namų modernizavimo projektų duomenys ........................ 129 


\section{Contents}

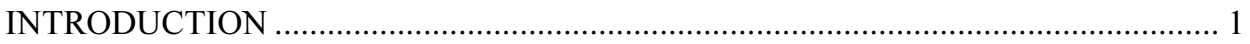

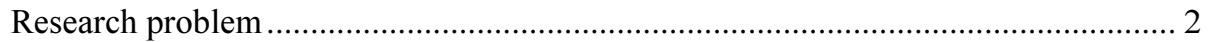

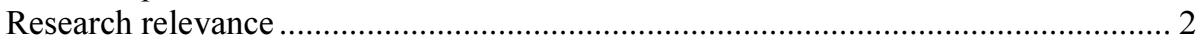

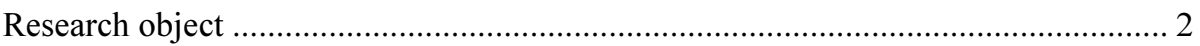

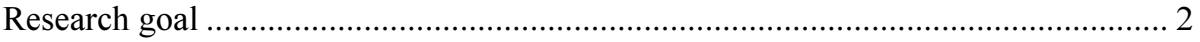

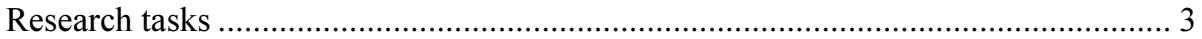

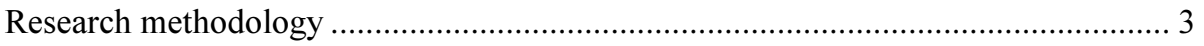

Original scientific contribution and significance of the research ................................. 4

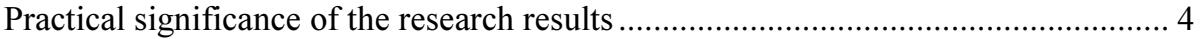

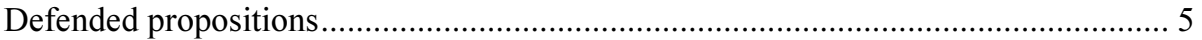

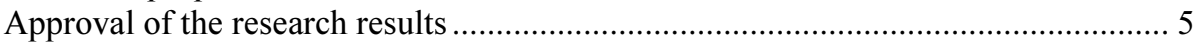

Structure of the dissertation.................................................................................. 5

1. CONSTRUCTION INDUSTRY IN TIMES OF ECONOMIC RECESSION IN

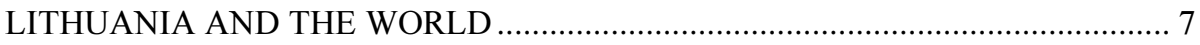

1.1. General features of construction as an industry ................................................ 7

1.2. Construction management models, methods and systems ................................. 16

1.3. Activities in a company operating in the construction industry ......................... 22

1.4. Possible ways (practices) to respond to a general economic recession .............. 25

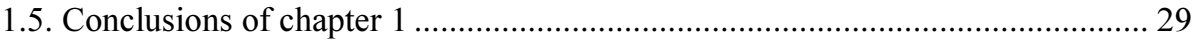

2. THE CONCEPTUAL MODEL OF CONSTRUCTION IN ENVIRONMENTAL OF

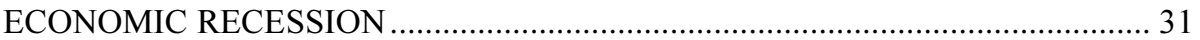

2.1. The concept of the model of construction in environment of economic recession 31

2.2. Components of the model of construction in environment of economic recession 33 2.2.1. Macrofactors affecting construction ..................................................... 33

2.2.2. Mesofactors affecting construction ......................................................... 42

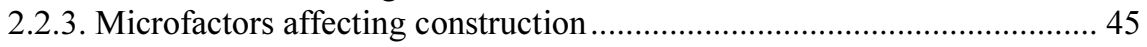


2.2.4. Interest groups 49

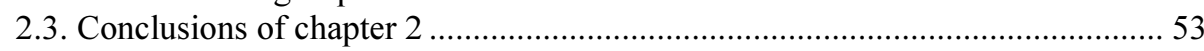

3. MULTI-VARIANT DESIGN AND MULTIPLE CRITERIA ANALYSIS OF CONSTRUCTION IN ENVIRONMENT OF ECONOMIC RECESSION................. 55

3.1. Preparing initial data for multiple criteria analysis........................................... 55

3.1.1. Data about the projects for refurbishment of apartmetn buildings ........... 70

3.1.2. Data about the long-term project for restoration of real estate heritage.... 73

3.2. Establishing weights of the evaluation criteria of construction in environment of economic recession using the integrated method

3.3. Multiple criteria complex proportional evaluation method for construction

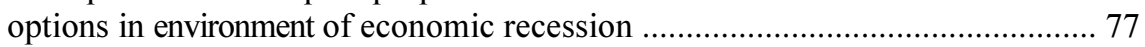

3.4. Comparison result of calculating with the TOPSIS method............................... 82

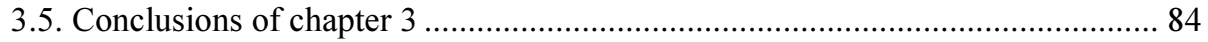

4. RECOMMENDABLE SYSTEM FOR CONSTRUCTION IN ENVIRONMENT OF

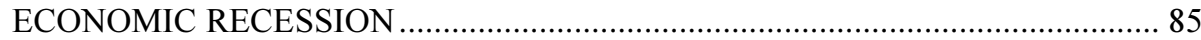

4.1. Components of the recommendable system for construction in environment of

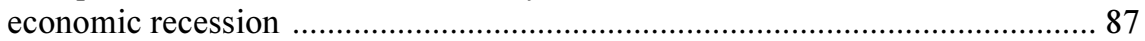

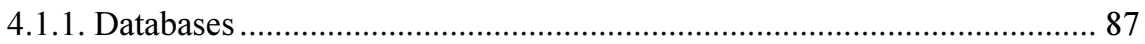

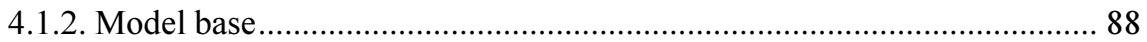

4.2. Multiple criteria analysis and multi-variant design of a construction project in

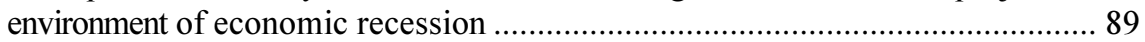

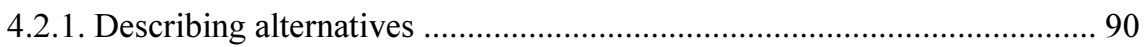

4.2.2. Multiple criteria analysis of components of a construction project in environment of economic recession ....................................................... 91

4.2.3. Multi-variant design of a construction project in environment of economic

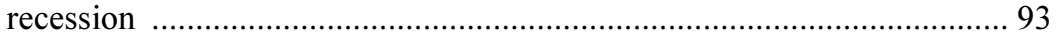

4.2.4. Recommendations for construction in environment of economic recession 95

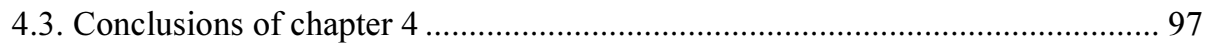

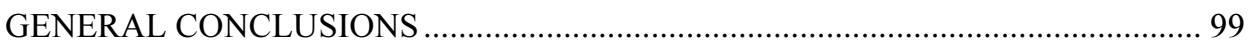

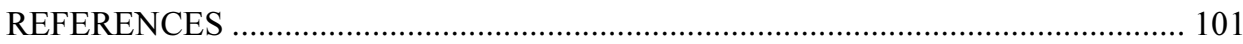

AUTHOR'S PUBLICATIONS RELATED TO THE DISSERTATION .................... 110

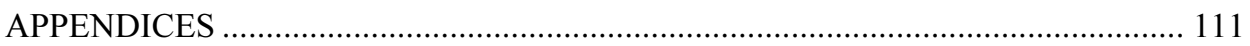

Appendix A. Determining the weights of the criteria defining refurbishment

project variants for apartment buildings in an integrated manner..................... 113

Appendix B. Determining the weights of the criteria defining restoration of the

manor (park and buildings) in an integrated manner ....................................... 116

Appendix C. Results of the multiple criteria analysis of refurbishment project

variants for apartment buildings .................................................................. 120

Appendix D. Results of the multiple criteria analysis of restoration of the manor

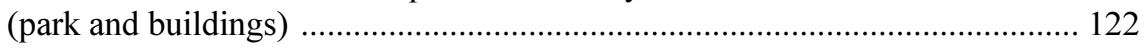

Appendix E. Data from the restoration project of pakruojis manor ........................ 125

Appendix F. Data from the refurbishment projects of 9-floor apartment buildings 129 


\section{Ivadas}

Statybos šaka visame pasaulyje keičiasi ir modernejja - iš ,gamybinio, i gamybą orientuoto" verslo transformuojasi i „paslaugu teikimo, klientu aptarnavimo“. Klientas tikisi gauti ne tik konstruktyvą - pastata, bet palankios gyventi ar dirbti aplinkos produktą ir paslaugų kompleksą. Pagal Lisabonos strategiją (Common Actions for Growth and Employment 2005), ,siekiant visiško užimtumo, darbo kokybès ir našumo gerinimo bei sustiprinti socialinę ir teritorinę sanglauda, reikia pritraukti ir išlaikyti daugiau žmonių, padidinti darbo pasiūla, modernizuoti socialinès apsaugos sistemas, pagerinti darbuotojų ir imonių galimybes prisitaikyti bei didinti investicijas į žmogiškaji kapitalą gerinant švietimą ir igūdžius“. Ankstesnis požiūris, kad kvalifikuoti darbuotojai pritraukiami tik pasiūlius aukštą atlyginima, nebetinkamas.

Bet kuri komercinè struktūra rinkos sąlygomis orientuota gauti pelno. Šio tikslo kelyje subjektai nuolatos rizikuoja ir konkuruoja konkrečioje teisineje ir politinejje aplinkoje. Rizika yra neatskiriamas ūkinès veiklos elementas: tai, kas rinkoje šiandien yra stabilu, rytoj gali pasikeisti. Paklausos ir pasiūlos svyravimas, konkurencija ir infliacija, daugelis kitų veiksnių nuolat keičia verslo aplinką. Dèl šios kintančios aplinkos verslui būdingas neapibrěžtumas, prognozuojamų rezultatų neužtikrintumas, rizikingi sprendimai. Rizikingi sprendimai gali slypèti tiek organizuojant verslą, tiek formuojant firmos strategiją, tiek pačiu vadovų veikloje, tiek konkurentų, tiekèjų veiksmuose, tiek vyriausybės sprendimuose, visuomenès kaitoje. Statybos dalyvis vieniems veiksniams gali daryti 
itaką, kitiems - tik iš dalies arba likti neutralus. Pastarajai veiksnių grupei priklauso makroaplinka. Geriau susipažistant su visomis itakomis atsiranda galimybė prognozuoti rezultatus, sumažinti neigiamas pasekmes arba pasiekti geresnių rezultatų.

\section{Tiriamoji problema}

Tiriamają problemą sudaro statybos projektu igyvendinimo ekonominio nuosmukio sąlygomis vertinimas, geriausių metodu ir priemonių kuriuos statybos imonès turetų naudoti, tikintis išlikti ir parduoti savo produkciją ar paslaugas, nustatymas taikant informacines ir intelektines technologijas.

\section{Darbo aktualumas}

Statybą veikia skirtingo lygio veiksniai, kurie gali būti įvairiai grupuojami. Statybos ekonominio nuosmukio aplinkoje modelio kūrimas ir inovacijos:

- suinteresuotoms grupèms (investuotojams, statybos įmonèms, projektuotojams, tiekejjams, valstybinėms institucijoms, naudotojams ir kt.) suteikia galimybę ivardinti ir aprašyti statybą veikiančią aplinka,

- padeda ịvertinti projektu igyvendinimo galimybes ir priimti sprendimus,

- nustato rizikingiausius veiksnius, darančius neigiamą itaką statybos rezultatui, leidžia laiku imtis prevencijos priemonių; ivertina perspektyviausias ar rizikingiausiai i̇monès veiklos ar pletros sritis,

- mažina darbo santykių stresa, didina darbo ir investicijų efektyvumą.

\section{Tyrimų objektas}

Tyrimų objektą sudaro veiksniai darantys įtaką statybai valstybės, visuomenės ir imonès lygiu, šiame procese dalyvaujančios suinteresuotos grupès bei ju siekiamybès.

\section{Darbo tikslas}

Darbo tikslas - sukurti statybos šakos ekonominio nuosmukio sąlygomis modeli ir jo pagrindu intelektinę sistemą, ivertinčią ir apibūdinančią statybos tendencijas, taikant sukurtą statybos esant bendriems ekonomikos sunkumams modeli. 


\section{Darbo uždaviniai}

Tikslui pasiekti reikia išspręsti tokius uždavinius:

1. Atlikti pasaulyje sukurtų metodų, modelių ir intelektinių sistemų analizę. Išanalizuoti Lietuvos ir užsienio patirti priimant statybos sprendimus ekonominio nuosmukio aplinkoje, taikant naujausias internetines, intelektines ir kitas technologijas bei inovacijas (1 skyrius).

2. Sukurti statybos esant bendram ekonomikos nuosmukiui koncepcini modeli (2 skyrius).

3. Sukurti kriterijų sistemą, išsamiai apibūdinančią statybos esant bendriems ekonomikos sunkumams aplinką (2 skyrius).

4. Statybos ekonominio nuosmukio sąlygomis modeli pritaikyti praktiškai (3 skyrius).

5. Atlikti statybos esant bendriems ekonomikos sunkumams aplinkos variantini projektavimą ir daugiakriterinę analizę (3 skyrius).

6. Modelio pagrindu sukurti rekomendacinę statybos ekonominio nuosmukio aplinkoje intelektinę sistemą (4 skyrius).

7. Rekomenduoti geriausius veiklos tobulinimo metodus ir priemones, kuriuos statybos imonès, veikiančios bendro ekonominio nuosmukio aplinkoje, turètų naudoti, tikintis išlikti ir parduoti savo produkciją ar paslaugas (4 skyrius).

\section{Tyrimų metodika}

Tyrimo metodikos paremtos Lietuvos ir užsienio šalių mokslininkų šioje srityje atliktų darbų analize. Atliktiems tyrimams pritaikyti ir papildyti daugiakriterinès analizès metodai, informacinès technologijos, analogijos principai, lyginamosios analizès, logikos ir sintezès metodai.

Rengiant darbą remtasi Lietuvos ir užsienio autorių mokslinèmis publikacijomis, statistiniais leidiniais, ivvairių šalių statistiniais duomenimis internete, kitais Lietuvos ir užsienio mokslo institucijų moksliniais bei informaciniais leidiniais.

\section{Darbo mokslinis naujumas ir jo reikšmè}

1. Sukurtas originalus statybos, kaip ūkio šakos, ekonominio nuosmukio aplinkoje daugiakriterinis modelis, išsamiai aptarti jo elementai. 
2. Sukurtam statybos ekonominio nuosmukio aplinkoje (SENA) modeliui buvo pritaikyti jau sukurti projektu variantinio projektavimo ir daugiakriterinès analizès metodai, kuriuos patobulinus buvo kompleksiškai įvertinti jo ekonominiai, techniniai, kokybiniai ir kiti aspektai.

3. Detaliai aprašyti makro-, meso- ir mikroaplinkos veiksniai, veikiantys SENA. Pateikta šių veiksnių įtaka SENA.

4. Atliktas statybos ekonominio nuosmukio aplinkoje modelio praktinis realizavimas.

5. Sukurta kriterijų sistema, išsamiai apibūdinanti statybos aplinką esant ekonominiam nuosmukiui.

6. Sukurta duomenų bazè, išsamiai apibūdinanti statybos projekto aplinką ekonominio nuosmukio sąlygomis.

7. Sukurta rekomendacinè statybos ekonominio nuosmukio sąlygomis supančios aplinkos intelektinè sistema.

8. Praktiškai realizuota sukurta intelektinès statybos ekonominio nuosmukio sąlygomis supančios aplinkos daugiavariantinè sprendimų paramos sistema.

\section{Darbo rezultatų praktinė reikšmė}

Sukurta originali rekomendacinè statybos ekonominio nuosmukio aplinkoje sistema, kuri gali būti taikoma priimant efektyvius statybos projektu valdymo sprendimus. Sistemos teikiamomis galimybemis gali naudotis ịvairios suinteresuotos grupès - investuotojai, rangovai, statybinių medžiagu gamintojai, tiekejjai, projektuotojai, naudotojai ir kt.

Tyrimų rezultatai buvo panaudoti Šiaulių universiteto mokymo procese rengiant paskaitas (Statybos verslas) vadybos specialybės su statybos specializacija magistrantams. 


\section{Ginamieji teiginiai}

1. Sukurtas statybos ekonominio nuosmukio aplinkoje modelis leidžia adekvačiai aprašyti suinteresuotų statybos dalyvių lūkesčius bei rinką juos veikiančią išorinę makro, meso ir mikro aplinką kaip vieną visumą ir padèti priimant efektyvų sprendimą.

2. Sukurta statybos apsunkintomis ekonominėmis sąlygomis duomenų bazè leidžia išsamiai apibūdinti statybos projekto veiksnius.

3. Sukurtam statybos ekonominio nuosmukio aplinkoje modeliui pritaikyti ir patobulinti projektų variantinio projektavimo bei daugiakriterinès analizès metodai leidžia automatizuotu būdu sudaryti daugybę alternatyvų, kompleksiškai ịvertinti jų ekonominius, techninius, kokybinius ir kitus aspektus bei padèti priimant sprendimą.

\section{Darbo rezultatų aprobavimas}

Disertacijos tema išdèstyta medžiaga skelbta 5 mokslo publikacijose.

Disertacijoje atliktų tyrimų rezultatai buvo paskelbti viename tarptautiniame koliokviume ir vienoje tarptautinèje mokslinejje konferencijoje:

- The 12th German-Lithuanian-Polish Colloquium "Sustainable Development in Civil Engineering and Multi-Attribute Decision Making": abstracts, May 20-24, 2009 Vilnius, Lithuania;

- International Young Scientists Conference, 29-30 April 2010, Šiauliai, Lithuania.

\section{Disertacijos struktūra}

Disertacija sudaro įvadas, keturi skyriai ir išvados (1 pav.). Taip pat yra 6 priedai.

Darbo apimtis - 112 puslapių (be priedu), tekste panauda 17 numeruotuc formulių, 36 paveikslai ir 15 lentelių. Naudotasi 106 literatūros šaltiniais. 


\section{IVADAS}

Tiriamojo problema; darbo aktualumas, tyrimo objektas, tikslas ir uždaviniai; tyrimų metodika; darbo mokslinis naujumas ir jo reikšmé; ginamieji teiginiai

\begin{tabular}{|c|c|}
\hline \multicolumn{2}{|c|}{ I SKYRIUS } \\
\hline \multicolumn{2}{|c|}{$\begin{array}{l}\text { Išskirtiniai statybos kaip ūkio šakos bruožai; statybos valdymo modeliai, me- } \\
\text { todai ir sistemos; imonès, dirbančios statybos srityje, veiklos elementai; galimi } \\
\text { reagavimo į bendrą ekonominį nuosmukị būdai (patirtis); pirmojo skyriaus } \\
\text { išvados. }\end{array}$} \\
\hline$\downarrow$ & $\checkmark$ \\
\hline II SKYRIUS & III SKYRIUS \\
\hline $\begin{array}{l}\text { Statybos ekonominio nuosmukio } \\
\text { aplinkoje modelio koncepcija; } \\
\text { statybos ekonominio nuosmukio } \\
\text { aplinkoje modelio elementų apra- } \\
\text { šymas; antrojo skyriaus išvados. }\end{array}$ & $\begin{array}{l}\text { Daugiakriterinei analizei reikalingu } \\
\text { pradiniu duomenu rengimas; staty- } \\
\text { bos ekonominio nuosmukio aplin- } \\
\text { koje vertinimo kriterijų reikšmin- } \\
\text { gumo nustatymas kompleksiniu } \\
\text { metodu; statybos alternatyvų eko- } \\
\text { nominio nuosmukio aplinkoje ver- } \\
\text { tinimas daugiakriterinio komplek- } \\
\text { sinio proporcingo ivertinimo meto- } \\
\text { du; trečiojo skyriaus išvados. }\end{array}$ \\
\hline \multicolumn{2}{|c|}{ IV SKYRIUS } \\
\hline \multicolumn{2}{|c|}{$\begin{array}{l}\text { Rekomendacinès statybos ekonominio nuosmukio aplinkoje sistemos sudeda- } \\
\text { mosios dalys; statybos ekonominio nuosmukio aplinkoje daugiakriterinè analizè } \\
\text { ir variantinis projektavimas; ketvirtojo skyriaus išvados. }\end{array}$} \\
\hline \\
\hline BENDRC & IŠVADOS \\
\hline
\end{tabular}

1 pav. Disertacijos struktūra

Fig. 1. Structure of the dissertation 


\section{1}

\section{Statybos šakos ekonominio nuosmukio sąlygomis Lietuvoje ir pasaulyje}

Šiame skyriuje analizuojama statybos kaip ūkio šakos koncepcijos samprata, apibrežimai, ir atliekama statybos ekonomikos bei proceso valdymo modeliu apžvalga. Pateikiami pasaulyje taikomų sistemų aprašymai, aptariamos statybos ekonominio nuosmukio aplinkos vertinimo sistemų taikymo galimybès užsiimant statyba.

Skyriaus tematika paskelbti trys autorès straipsniai (Kaklauskas et al. 2009, Kelpšienè, Matusevičienè 2009, Petrošius, Kelpšienè 2010).

\subsection{Išskirtiniai statybos kaip ūkio šakos bruožai}

Lietuvos ūkio struktūra per pastaraji dvidešimtmeti patyrè radikalių pokyčių. Joje gerokai padaugèjo didmeninès ir mažmeninès prekybos bei kitu paslaugų, gerokai sumažejjo pramonès dalis. Lietuvos ūkio raidą ir jos struktūros pertvarką lèmé: perejimas i rinkos ekonomiką ir atviros ekonomikos principų pritaikymas; susiklosčiusi būtinybè atlikti šakinę šalies ūkio restruktūrizacija; spartus tarptautinio bendradarbiavimo procesas ir galimybès dalyvauti pasaulinejje prekių rin- 
koje ir panašūs veiksniai. Lietuvos ūkyje 1991-1995 m. pasireiškusi gili ekonominè krizė padarè tiesioginę įtaką struktūrinès politikos formavimui.

Statybos sektoriaus tikslas - sukurti žmogaus veiklai urbanizuotą ir humanizuotą aplinką. Dabartinei vartotojiškai visuomenei būdinga ne tik auganti pragyvenimo kokybè, bet ir senkantys gamtos ištekliai bei didejjanti aplinkos tarša. Visa tai lemia poreiki subalansuoti pagrindinio statybos sektoriaus produkto pastato - gyvavimo procesą (aprépiant visas stadijas: vizijos formulavimo, projektavimo, statybinių medžiagų ir gaminių gamybos, statybos, eksploatavimo, pastatų ūkio valdymo, nugriovimo, utilizavimo ir antrinio medžiagų bei gaminių naudojimo).

Statyba yra viena svarbiausių ūkio šakų. Statybos pletotę charakterizuojantys rodikliai nusako ir bendrą šalies ekonomikos lygi. Natūralu, kad statant pastatus, tiltus ir kitokius objektus pletojasi ir kitos ūkio šakos, gerejja visos šalies ekonomika (Zavadskas 2000).

Vienos pramonès i̇monès skiria visą savo produkciją statybai (statybinès medžiagos ir gaminiai), kitos - tik dali produkcijos (chemijos, tekstilès gaminiai). Kai sukuriama viena darbo vieta tiesiogiai statybos sektoriuje, automatiškai sukuriamos dvi darbo vietos kitose su statyba susijusiose pramonès šakose.

$2008 \mathrm{~m}$. daugelio statybinių medžiagų gamyba Lietuvoje mažejo. Portlandcemenčio gamyba sumažejo $0,54 \%$, gamyklinio statybinio skiedinio gamyba $0,9 \%$, silikatiniu plytu ir blokeliu gamyba smuko 34,6\%, statybinių blokų ir plytu $-37,8 \%$, šlako vatos ir akmens vatos $-30 \%$. $2009 \mathrm{~m}$. duomenys rodo dar didesni smukimą: 38,8 \% sumažejo statybinio smèlio gamyba, 61 \% sumažèjo dolomito skaldos, naudojamos betono užpildui, gamyba, $46 \%$ sumažèjo portlandcemenčio gamyba, 67,6 \% sumažèjo silikatinių plytų ir blokelių gamyba, 30,7 \% sumažejo ugniai atsparaus cemento, statybinių skiedinių, betono ir panašių mišinių gamyba, 83 \% sumažejo statybinių blokų ir plytų iš cemento gamyba, 42 \% sumažèjo šlako vatos, akmens vatos gamyba, 56 \% sumažèjo gamykloje pagaminto statybinio skiedinio gamyba (Statistikos departamentas).

Statyba kaip ūkio šaka turi svarbią reikšmę tiek nacionalinei ekonomikai, tiek viso Europos Sajungos ūkio integracijai:

- dalyvauja materialinių vertybių kūrimo procese (statomos ir modernizuojamos pramonès imonès, gyvenamieji ir visuomeniniai pastatai, infrastruktūros, aplinkos apsaugos ir kt. statiniai);

- yra valstybès ịrankis vykdant konjunktūros, regionų plètros, sveikatos apsaugos politiką ir sprendžiant kitus klausimus;

- yra pagrindinis darbdavys nacionalinejje ekonomikoje.

Vienas iš rodikliu, charakterizuojančių statybos sektorių, yra statybos apimtys. Statybai, kaip ir daugeliui kitų sričių, ypač būdingas sezoniškumas. pateikiant statistinius duomenis lyginami ne gretimi ketvirčiai, o atitinkami skirtingų metų ketvirčiai. 
$2008 \mathrm{~m}$. išduoti 2293 statybos leidimai statyti 3088 negyvenamuosius pastatus, o tai yra 81 leidimu mažiau negu 2007 m. (Statistikos departamentas). Bendrasis leistų statyti negyvenamuju pastatų plotas - apie 1991 tūkst. $\mathrm{m}^{2}$, t. y. 255 tūkst. $\mathrm{m}^{2}$ mažiau negu $2007 \mathrm{~m}$. Daugiausia (28\%) pagal bendraji plotą leista statyti prekybos, viešbučių ir maitinimo imonių pramoninių ir sandèlių pastatų $(27 \%)$ ir kt. Visų išduotų statyti negyvenamuosius pastatus leidimų statyti skaičius 2008 m. mažesnis, lyginant su 2007 m., išskyrus negyvenamujų ūkinių pastatu kategoriją (1.1 lentelè), o tam įtaką darè isibègejjusi Europos Sajungos parama Lietuvos ūkininkams.

1.1 lentelè. Išduotų leidimų naujų negyvenamujų pastatų statybai skaičiaus kitimas

Table 1.1. Variation in numbers of permits for new non-residential construction

\begin{tabular}{|c|c|c|c|c|c|c|c|c|c|}
\hline & 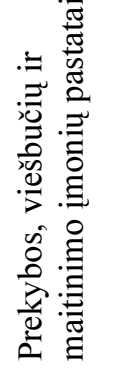 & 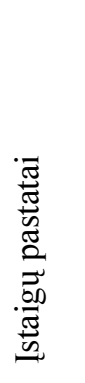 & 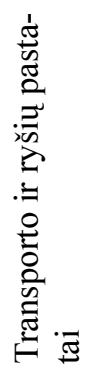 & 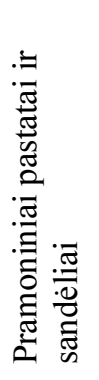 & 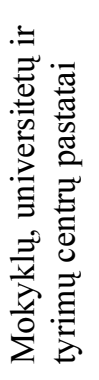 & 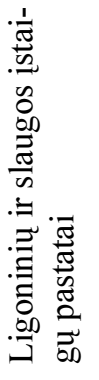 & 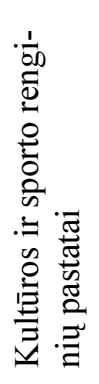 & 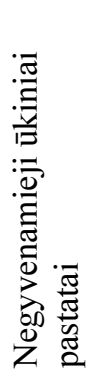 & 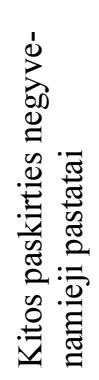 \\
\hline 2000 & 193 & 33 & 117 & 156 & 5 & 4 & 7 & 172 & 147 \\
\hline 2001 & 202 & 30 & 78 & 159 & 9 & 6 & 9 & 183 & 108 \\
\hline 2002 & 193 & 35 & 95 & 163 & 4 & 13 & 16 & 251 & 173 \\
\hline 2003 & 189 & 42 & 95 & 214 & 10 & 10 & 13 & 319 & 245 \\
\hline 2004 & 236 & 50 & 110 & 214 & 7 & 7 & 18 & 442 & 789 \\
\hline 2005 & 269 & 64 & 95 & 233 & 7 & 8 & 7 & 526 & 466 \\
\hline 2006 & 228 & 75 & 68 & 218 & 14 & 8 & 19 & 712 & 587 \\
\hline 2007 & 344 & 83 & 105 & 228 & 10 & 11 & 16 & 888 & 689 \\
\hline 2008 & 286 & 93 & 87 & 225 & 6 & 8 & 14 & 963 & 611 \\
\hline 2009 & 286 & 47 & 64 & 193 & 15 & 8 & 18 & 924 & 536 \\
\hline 2010 & 168 & 44 & 57 & 163 & 21 & 18 & 18 & 658 & 432 \\
\hline
\end{tabular}

Statybos leidimas galioja dešimt metų, tad dažnai tais pačiais metais būna realizuojami ne visi išduoti leidimai. Tad tikroji statybos apimčių augimo ar lètèjimo tendencija išaiškejja vèliau (1.1 pav. (Statistikos departamentas)).

Visų pastatomų pastatų naudingojo ploto kvadratiniais metrais didesnę dali (vidutiniškai apie $60 \%$ ) sudaro būtent negyvenamosios statybos produkcija. Ekonomiškai sudètingu periodu ši dalis labiausiai smunka. 


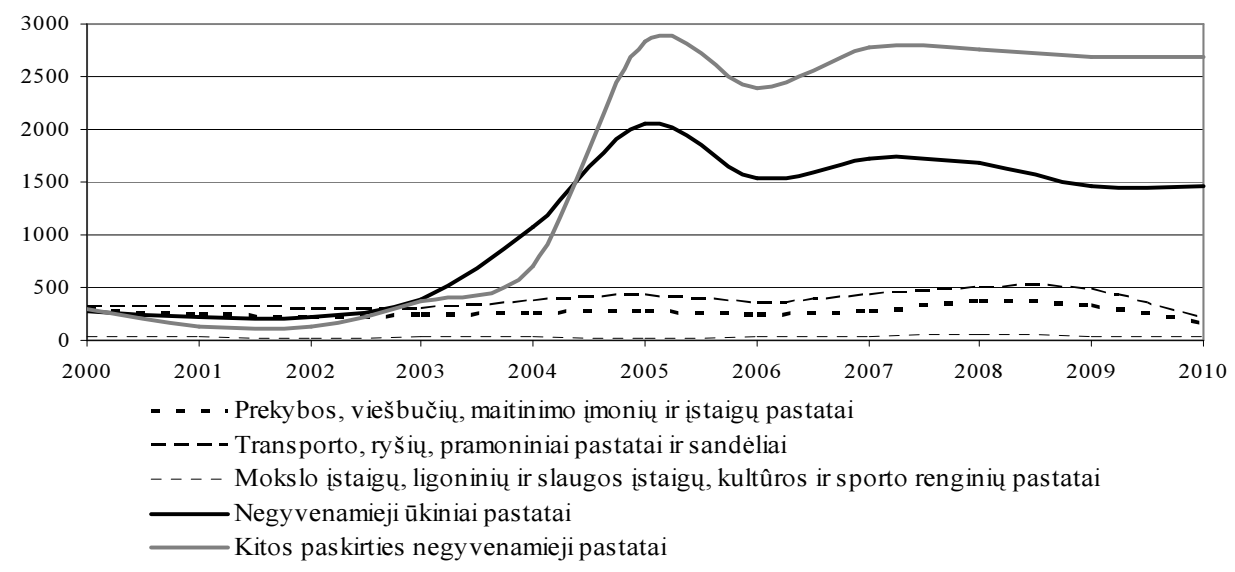

1.1 pav. Pastatyta naujų negyvenamujų pastatų

Fig. 1.1. Number of new non-residential buildings

2000 metu duomenys rodo, kad smukimas dèl Rusijos krizès buvo toks didelis, kad antraji tų metų ketvirti negyvenamujų patalpų statyba tiek sumažejo, jog gyvenamuju patalpų statybos apimtys sudare apie $63 \%$ viso naudingojo ploto. Panašūs rezultatai yra 2009 metu pirmaisiais ketvirčiais - gyvenamoji statyba, palyginti su negyvenamaja, ryškiai nesmunka (1.2 pav. (Statistikos departamentas)). $2010 \mathrm{~m}$. pradžios duomenų lygis artimas 2000-2002 m. lygiui.

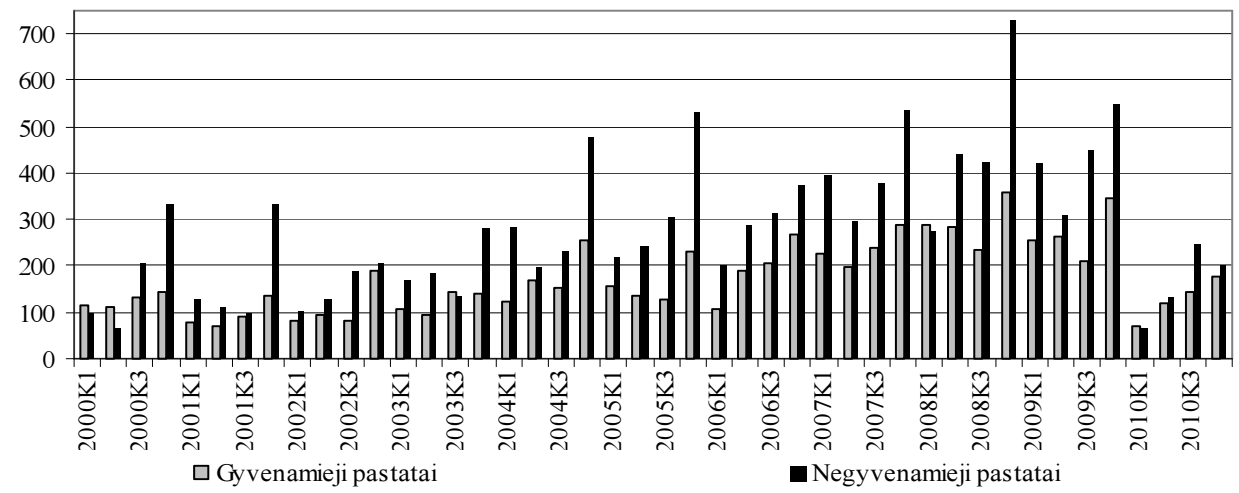

1.2 pav. Pastatytų naujų gyvenamujų ir negyvenamuju pastatų naudingasis plotas tūkstančiais kvadratinių metrų

Fig. 1.2. Basic floor area of new residential and non-residential buildings, ' 000 sq. $m$

Būstą (arba gyvenamąsias patalpas) nekilnojamojo turto įstatymas apibūdina kaip vienbuti gyvenamaji namą jo dali, butą ar kitas gyvenamąsias patalpas, tinkamas asmeniui arba šeimai gyventi. Butas suvokiamas kaip gyvenamojo 
namo dalis iš vieno ar kelių gyvenamujų kambarių, virtuvès bei kitu patalpų, atskirta nuo bendrojo naudojimo patalpų, kitų butu ar negyvenamuju patalpų atitvarinemis konstrukcijomis. Gyvenamasis namas - tai gyventi pritaikytas pastatas, kurio daugiau kaip puse naudingojo ploto yra gyvenamosios patalpos (STR 1.01.09:2003). Taigi svarbiausias bruožas, išskiriantis būstą iš kitų nekilnojamo turto rūšių, yra tas, kad jo naudingasis plotas turi būti tinkamas gyventi žmogui.

Lietuvos Vyriausybè numato siekti, kad gyvenamojo fondo struktūra ir jo kokybė geriau atitiktu i̇vairių gyventojų sluoksnių poreikius, remti senų būstų atnaujinima, kompleksiškai modernizuoti namus, statytus anksčiau nei prieš 20 metų, teikti finansinę paramą apleistiems ir bešeimininkiams statiniams sutvarkyti, plèsti socialinio būsto statybą mažas pajamas turintiems gyventojams. Pritraukti tarptautinius finansinius išteklius būstui finansuoti, socialiniam būstui, nebaigtai statybai, pastatams modernizuoti, ieškoti ir taikyti veiksmingesnes kreditavimo priemones, kurios plètotų būsto kreditavimo rinką (Lietuvos ūkio (ekonomikos) plètros iki 2015 metų ilgalaikè strategija 2002).

Mažejjantys butų pirkimo mastai ir stingstanti nekilnojamojo turto rinka verčia nerimauti statybos ir nekilnojamojo turto verslo atstovus, mažinti butų statybos planus (1.2 lentelè (Statistikos departamentas)). Planuojant statyti mažiau naujų butu̧, atsigręžiama i galimybes renovuoti senus daugiabučius namus.

1.2 lentelè. Išduota leidimų naujų gyvenamuju pastatų statybai

Table 1.2. Number of permits for new residential construction

\begin{tabular}{|l|c|c|c|c|c|c|c|c|c|c|c|}
\hline & 2000 & 2001 & 2002 & 2003 & 2004 & 2005 & 2006 & 2007 & 2008 & 2009 & 2010 \\
\hline $\begin{array}{l}\text { Vieno ir } \\
\text { dviejų } \\
\text { būstu } \\
\text { pastatai }\end{array}$ & 1797 & 1881 & 2256 & 2802 & 3930 & 5407 & 7370 & 8574 & 8053 & 5938 & 5764 \\
\hline $\begin{array}{l}\text { Trijų ar } \\
\text { daugiau } \\
\text { būstu } \\
\text { pastatai }\end{array}$ & 56 & 61 & 36 & 56 & 71 & 78 & 115 & 226 & 134 & 56 & 106 \\
\hline $\begin{array}{l}\text { Bendra- } \\
\text { bučiai }\end{array}$ & 0 & 0 & 0 & 1 & 0 & 3 & 1 & 0 & 2 & & 6 \\
\hline
\end{tabular}

2007 m. pabaigoje Lietuvoje gyvenamaji fondą sudare 1305100 butų. Iš jų dviejų kambarių butu $-39,0 \%$, triju $-29,2 \%$, vieno $-14,2 \%$, keturių $-10,1 \%$, penkių ir daugiau kambarių - 7,5\%. 1000 gyventojų teko 388 butai. Vidutinis vieno buto naudingasis plotas buvo $62,1 \mathrm{~m}^{2}$, mieste $-58,2 \mathrm{~m}^{2}$, kaime $-70,1 \mathrm{~m}^{2}$ (Lietuvos Respublikos statistikos departamento metraštis 2008). 2008 m. daugiabučiu namų statyba išaugo $30 \%$. Daugiabučiuose namuose įrengti $66 \%$ visų pastatytų butu (1.3 pav.). 


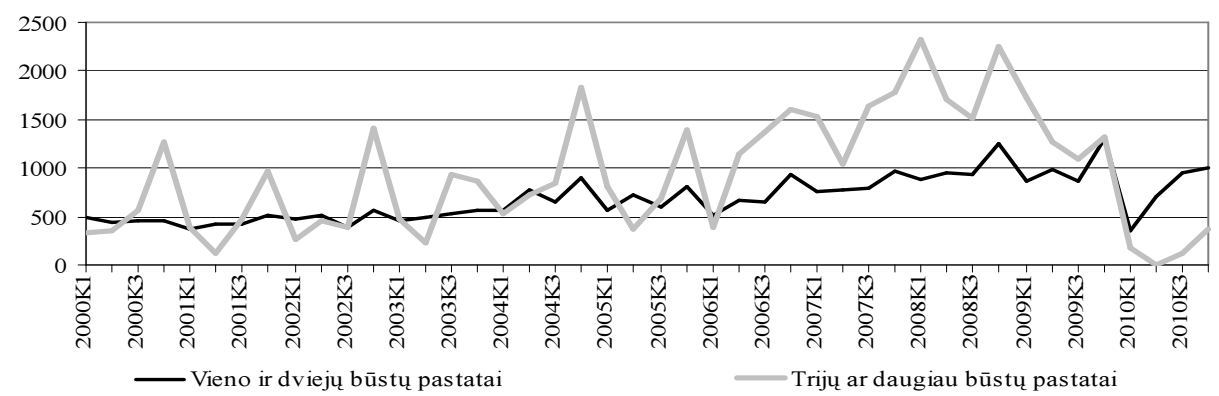

1.3 pav. Pastatyta naujų butu

Fig. 1.3. Number of new constructed flats

Kita charakteristika - statybos sektorius lyginamoji dalis bendrajame vidaus produkte. Nagrinejant Europos Sajungos senbuves procentinè statybos sektoriaus dalis BVP svyruoja nuo 8,3 iki 15 (1.3 lentelè).

1.3 lentelè. Statybos apimties lyginamoji dalis Europos Sajungos šaliu bendrajame vidaus produkte

Table 1.3. Comparative share of construction output in the Gross Domestic Product of EU countries

\begin{tabular}{|c|c|}
\hline Valstybė & $\begin{array}{c}\text { Statybos apimties lyginamoji dalis } \\
\text { bendrajame vidaus produkte, } \%\end{array}$ \\
\hline Vokietija & 13,3 \\
\hline Prancūzija & 11,3 \\
\hline Italija & 10,1 \\
\hline Didžioji Britanija & 8,4 \\
\hline Ispanija & 15,0 \\
\hline Nyderlandai & 10,7 \\
\hline Austrija & 13,6 \\
\hline Belgija & 10,6 \\
\hline Švedija & 10,8 \\
\hline Portugalija & 13,8 \\
\hline Danija & 8,3 \\
\hline Suomija & 11,6 \\
\hline Graikija & 10,1 \\
\hline Airija & 10,3 \\
\hline Liuksemburgas & 10,6 \\
\hline
\end{tabular}

Lietuvai pradèjus tvarkytis savarankiškai, statybos sektorius ėmè sparčiau augti 1997-1998 m. (1.4 pav.). Kitas šuolis susijęs su Lietuvos įstojimu i Europos Sajungą (Eurostat). Užgriuvus krizei, statybos sektoriaus smukimas daug ryškesnis už 27 Europos Sajungos šalių vidurkị. 


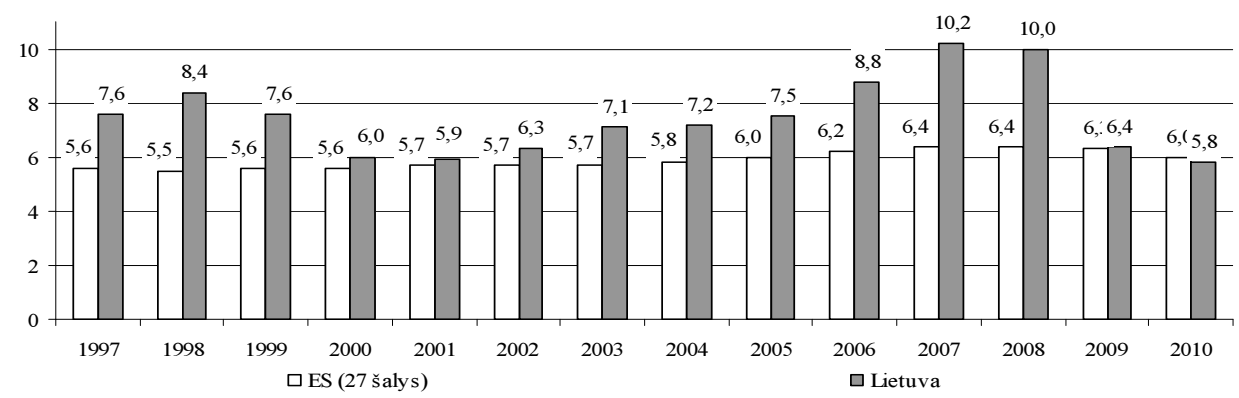

1.4 pav. Statybos sektoriaus sukuriamos pridètinès vertès kitimas, procentais nuo bendrosios vertès

Fig. 1.4. Added value variations in construction, $\%$ of the gross value added

Skaidant Lietuvos vidaus bendraji produktą $i$ smulkesnes sudedamąsias dalis pagal ūkio sritis, ryškèja, kad statybos sektoriaus procentinè dalis pakilimo laikotarpiu buvo pasiekusi 9,2 proc. lygi (Statistikos departamentas), tačiau per $2009 \mathrm{~m}$. smuko beveik perpus (1.4 lentelè).

1.4 lentelè. Bendrasis vidaus produktas to meto kainomis, mln. litų ir procentais

Table 1.4. Gross Domestic Product, LTL $m$ and \%, at then prices

\begin{tabular}{|l|r|r|r|r|r|r|r|r|r|r|}
\hline & \multicolumn{2}{|c|}{2006} & \multicolumn{2}{|c|}{2007} & \multicolumn{2}{|c|}{2008} & \multicolumn{2}{|c|}{2009} & \multicolumn{2}{|c|}{2010} \\
\cline { 2 - 13 } & mln. Lt & \% & mln. Lt & \% & mln. Lt & \% & mln. Lt & \% & mln. Lt & \% \\
\hline A+B & 3212 & 3,9 & 3484 & 3,5 & 3713 & 3,9 & 2770 & 3,0 & 2967 & 3,1 \\
\hline C-E & 17986 & 21,7 & 19772 & 20,0 & 21568 & 19,2 & 16934 & 18,5 & 18898 & 20,0 \\
\hline F & $\mathbf{6 5 5 4}$ & $\mathbf{7 , 9}$ & $\mathbf{9 0 4 8}$ & $\mathbf{9 , 2}$ & $\mathbf{9 9 8 8}$ & $\mathbf{9 , 0}$ & $\mathbf{5 2 8 0}$ & $\mathbf{5 , 8}$ & $\mathbf{4 9 2 6}$ & $\mathbf{5 , 2}$ \\
\hline G-I & 23025 & 27,8 & 27188 & 27,6 & 30562 & 26,9 & 26424 & 28,9 & 28193 & 29,8 \\
\hline J+K & 11187 & 13,5 & 14449 & 14,6 & 16648 & 14,9 & 13618 & 14,9 & 13539 & 14,3 \\
\hline L-P & 12714 & 15,4 & 14470 & 14,7 & 17424 & 15,7 & 17402 & 19,0 & 16087 & 17,0 \\
\hline D21 & 9038 & 10,9 & 11298 & 11,5 & 12801 & 11,5 & 10372 & 11,3 & 11056 & 11,7 \\
\hline D31 & 922 & 1,1 & 1040 & 1,1 & 1223 & 1,1 & 1273 & 1,4 & 1040 & 1,1 \\
\hline BVP & $\mathbf{8 2 7 9 3}$ & 100 & 98669 & 100 & 111483 & 100 & 91526 & 100 & 94625 & 100 \\
\hline
\end{tabular}

\section{Reikšmès:}

A - Žemès ūkis, medžioklè ir miškininkystè

B - Žuvininkystè

C - Kasyba ir karjerų eksploatavimas

D - Apdirbamoji gamyba

E - Elektros, dujų ir vandens tiekimas

F - Statyba

$\mathrm{G}$ - Didmeninè ir mažmeninè prekyba

$\mathrm{H}$ - Viešbučiai ir restoranai

I - Transportas, sandeliavimas ir ryšiai

\author{
$\mathrm{J}$ - Finansinis tarpininkavimas \\ $\mathrm{K}$ - Nekilnojamasis turtas, nuoma ir kita verslo veikla \\ $\mathrm{L}$ - Viešasis valdymas ir gynyba \\ M - Švietimas \\ $\mathrm{N}$ - Sveikatos priežiūra ir socialinis darbas \\ $\mathrm{O}$ - Komunalinè, socialinè ir asm. aptarnavimo veikla \\ $\mathrm{P}$ - Privačių namų ūkių veikla \\ D21 - Mokesčiai gaminiams (+) \\ D31 - Subsidijos gaminiams (-)
}

Nemenką BVP dalį vis dèlto sudaro aptarnavimo, paslaugų teikimo sferos nuo didmeninès ir mažmeninès prekybos iki komunalinio ir socialinio aptarnavimo - visos kartu jos sudaro apie $60 \%$ viso bendrojo vidaus produkto (1.5 pav. 
(Statistikos departamentas)). Statybos sektoriaus produkcijos viena dalis traktuojama kaip gamybinè, o kita - kaip paslaugos. Tad ir BVP sandaroje ši šaka užima ribos (,pasienio“) vietą tarp paslaugu teikimo ir gamybinių sektorių - nuo žemès ūkio iki elektros, dujų ir vandens tiekimo.

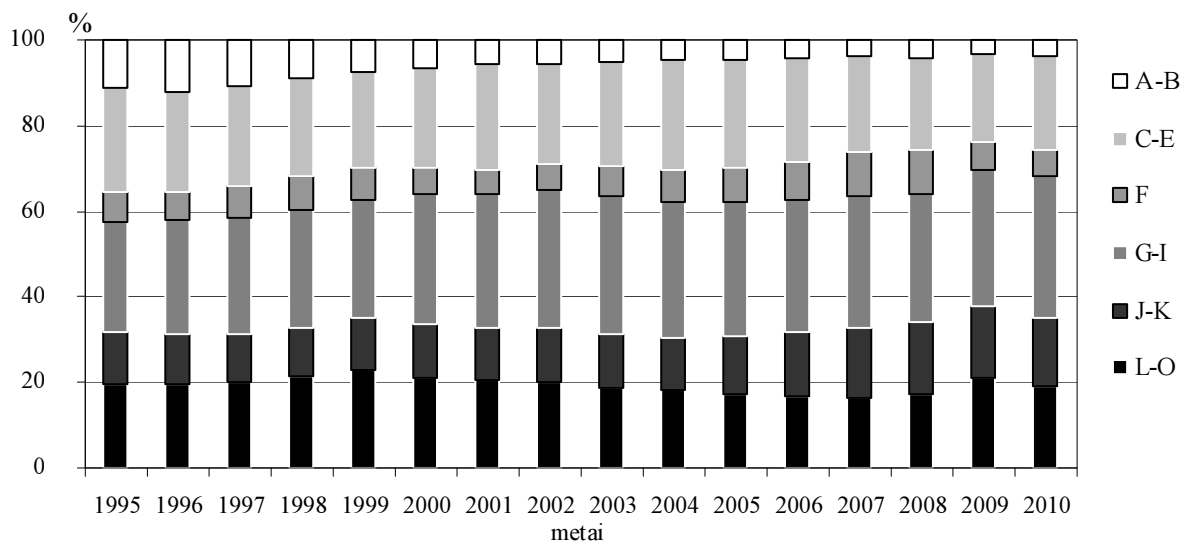

1.5 pav. Lietuvos bendrojo produkto procentinè sandara

Fig. 1.5. Percentages in Lithuania's gross product

Ir visose ekonominio gyvenimo srityse, ir statyboje paskutiniu metu tendencijos blogejja. Atlikus apklausą (Statistikos departamentas) aiškejja, kad, palyginti su praejjusiais ménesiais, darbų sumažejo. Net $92 \%$ visų apklaustu i̇monių vadovų teigè, kad statybos darbu paklausa nepakankama. Kad finansinè imonių padètis pablogejo, pripažino $77 \%$ apklaustuju ir tik $3 \%$ teigè, kad pagerèjo. Darbuotojų skaičių žada mažinti $74 \%$ apklaustų i̇monès vadovų didinti - tik $1 \%$. Statybos darbų kainų mažèjimą prognozuoja $71 \%$ imonių vadovų. Kaip svarbiausią statybos i̇monių veiklos trikdị $77 \%$ vadovų nurode mažèjančią paklausa, o finansinius sunkumus $-46 \%$, tik $2 \%$ imonių vadovų teigè, kad jų veiklai netrukdo niekas.

Nuo $2002 \mathrm{~m}$. sparčiausiai iš visų statybos kainos sudedamujų dalių augo darbo užmokestis ir pridètinès išlaidos (1.6 pav.). Šis augimas ypač suintensyvėjo Lietuvai isstojus i Europos Sajunga 2004-aisiais. Prasidejus ekonominiams sunkumams mažiausiai keitèsi medžiagų ir gaminių sąnaudos, o darbo užmokestis ir pridètinès išlaidos smuko nuo 23,9 \% 2008-ujų sausį iki - 23,7 \% 2009-ujų kovą (Statistikos departamentas). 


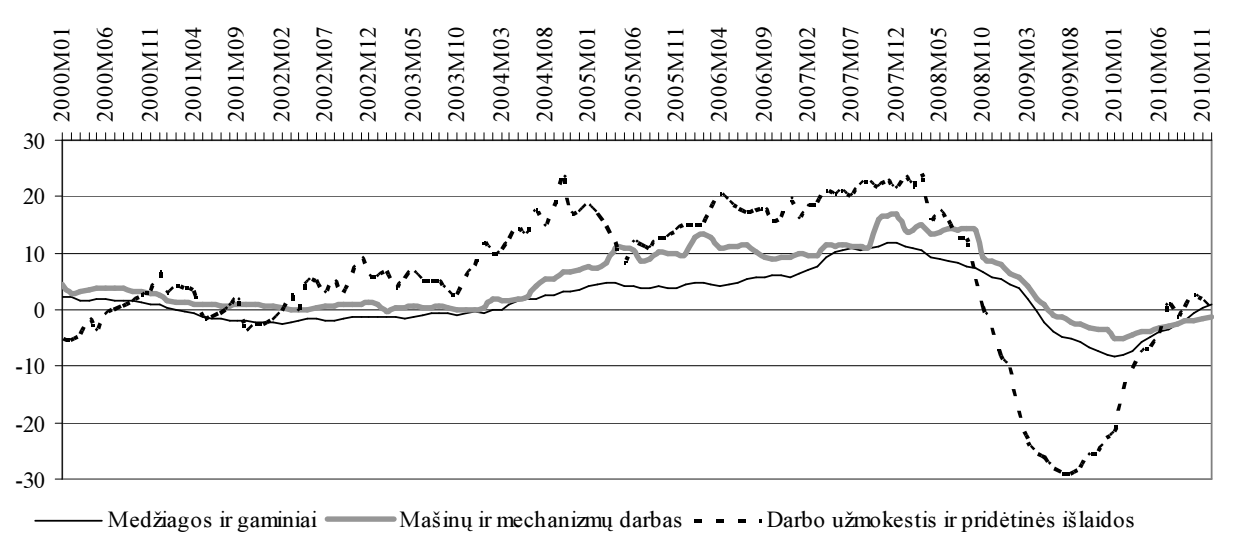

1.6 pav. Pagrindinių sąnaudų grupių statyboje kitimas, palyginti su ankstesnių metų atitinkamu mènesiu

Fig. 1.6. Variation of the main cost groups in construction, compared to the same month previous year

Mažejjant domejjimuisi nekilnojamuoju turtu ir bankams griežtinant paskolų teikimo sąlygas statybos imonių prašoma pateikti preliminarias butų pirkimo sutartis, taip pat reikalaujama, kad ir patys statytojai būsimoms statyboms skirtu daugiau lèšų. Dèl lèšų trūkumo mažèja galimybès atsiskaityti su tiekejjais ir darbuotojais. Negavusios paskolų i̇monès priverstos stabdyti statybas ir užšaldyti pradètus projektus.

Bet kokios statybos idejja prasideda nuo statytojo (užsakovo). Statytoju Lietuvos teritorijoje gali būti fiziniai ar juridiniai asmenys turintys ar valdantys nuosavybès teise žemès sklypa, turintys patvirtintą statinio projektą ir galiojantị leidimą statyti. Lietuvos Respublikos Konstitucija ilgą laiką ribojo užsienio piliečiams ir juridiniams asmenims galimybes issigyti žemès sklypus privačion nuosavybėn. 1996 m., derinant mūsų teisinę bazę prie Europos Sajungos normų, buvo pirmą kartą pakeistas 47 straipsnis, kuriuo užsieniečiams suteikiama teisė isigyti ne žemès ūkio paskirties žemès sklypus. Dabartinèje pagrindinio įstatymo redakcijoje yra tokia nuostata: žemę, vidaus vandenis ir miškus issigyti nuosavybèn Lietuvos Respublikoje užsienio subjektai gali pagal konstitucini istatymą (Lietuvos Respublikos konstitucija 1992).

Iš Statybos įstatymo nuostatu galima daryti išvadą, kad bet kokios statybos atveju susiduriama su teisiniais žemès santykiais - visi statiniai susiję su žeme, statybos teisès igyvendinimas susijęs su teisiniu žemès statusu ir t.t. Žemès teisè - teisès šaka, kuri reguliuoja žemès nuosavybès, naudojimo ir valdymo bei apsaugos teisinius santykius, nustato šių teisinių santykių subjektų teises, pareigas, atsakomybę ir žemès ginčų sprendimo tvarką. Pagrindiniai žemės teisės 
šaltiniai yra Konstitucija, Žemès įstatymas, Žemès nuomos įstatymas, Žemès mokesčių istatymas, Žemès reformos įstatymas.

Verslui reikalingos infrastruktūros vystymui, o ir socialinèms programoms valstybei būtinos lèšos statybos i̇monei, kaip ir kitoms pelno siekiančioms organizacijoms, tenka tam tikra mokesčiu našta. Ekonomikos mechanizme mokesčių vaidmuo dvejopas. Iš jų valstybė ne tik formuoja savo pajamas (tai yra istoriškai susiklosčiusi jos fiskalinė funkcija), bet ir netiesiogiai skatina ekonomiką. Mokesčių tarifais (mokejjimų už ką nors normomis arba normų sąrašais), sankcijomis (valstybinio poveikio priemonemis, taikomomis nustatytų normų ir taisyklių pažeidejjams), lengvatomis realizuoti ekonominę politiką yra daug veiksmingiau, negu tiesiogiai kištis į ūkinę veiklą.

\subsection{Statybos valdymo modeliai, metodai ir sistemos}

Kai kurių statybos pramonès sričių produkcijos realizavimo svyravimai $20 \%$ lygmeniu yra iprasti. Pastebèta, kad statybos pramonès vystimuisi būdingi pakilimo ir nuosmukio ciklai kartojasi apytikriai kas dešimt metų (Yisa et al. 1996; Loosemore 1997). Statybos i̇monès, priimančios ši cikliškumą kaip nenuginčijamą faktą ir realybès dali, pakilimo laikotarpiu sugeba pasiruošti būsimam nuosmukiui. Jos dažniausiai renkasi ilgalaikes vadybos strategijas, kurios leidžia lengviau pergyventi sunkmeti (Lovelock 1997; Sheridan 1997).

Didžiojoje Britanijoje vykdyti statybos sektoriaus imonių tyrimai (Bennett 2005) buvo skirti tam, kad nustatytu geriausius metodus, kuriuos kompanijos, veikiančios ciklinès ekonominès aplinkos sąlygomis, renkasi pardavinėdamos savo produkciją. Vienos imonès stengèsi išlaikyti kainas ankstesnio lygmens, kitos bandè derintis prie pakitusių salygų, bet tai nelèmè veiklos rezultatų. Autoriaus nuomone, imonès turi panaudoti smukima, kad užkariautų rinkos dalị ir praplèstų ilgalaikius santykius su klientais. Nepatartina mažinti rinkodaros biudžeto ir siaurinti pradètas igyvendinti programas. Efektyviau dirbo įmonès, taikančios ilgalaikes rinkodaros strategijas.

Tradicinè statybos ir nekilnojamojo turto sektoriaus krizès analizė grindžiama ekonominiais, teisiniais, instituciniais ir politiniais aspektais (Loosemore, Teo 2000; Lim et al. 2011). Pavyzdžiui, Lu ir So (2005) nuomone, staigus Azijos ūkių žlugimas per $1997 \mathrm{~m}$. finansinę krizę buvo daugelio tyrimų tema, tačiau didžioji dalis studijų susitelkiama i pagrindinius ekonomikos principus. Krizei iveikti buvo pasitelktos Franklino Roosevelto naudotos paklausos stimuliavimo priemonès taikytos per JAV Didžiają depresiją. Tačiau jų efektyvumas, autorių nuomone, abejotinas, nes iš tiesu iveikti depresija padejo karas. Kadangi nekilnojamojo turto rinka yra glaudžiai susijusi su bet kurio ūkio finansiniu stabilumu, tikima- 
si, kad Azijos patirtis gali parodyti kaip tobulinti nekilnojamojo turto paskolų skyrimo procesa.

Rezultatai (Ocal et al. 2006) parodè, kad vyriausybès politika ir nestabili rinka lèmé 2001 metų krizę Turkijos statybos kompanijose. Panikos ir bejègiškumo pojūtis užvalde pramonę. Efektyvumo koeficiento reikšmès papildomai patvirtino fakta, kad kompanijos be krizinių vadybos priemonių patyre didesni chaosa. Vadybininkų paklausus apie jų prioritetus 2001 metų ekonominès krizès pabaigoje, beveik visi respondentai išdèstè, kad jie norejo pakeisti savo organizacinę struktūrą ir skverbtis i naujas rinkas. $76 \%$ respondentų išdèstè, kad jie nagrinejo savo kompanijos jègas ir silpnybę po krizès, tik $58 \%$ teigè, kad jie turèjo grị̌ztamaji ryší, kad pagerintų kompanijos sistemas.

Sèkmingos statybos krizès valdymo strategijos turi būti suderintos su konkrečios šalies ekonominemis, politinemis, teisinemis, technologinèmis, techninèmis, organizacinèmis, vadybos, institucinèmis, socialinèmis, kultūrinèmis, etinèmis, psichologinėmis, švietimo, aplinkosaugos, pasitikejjimo ir kitomis situacijomis (Lam et al. 2011). Ivairūs strategijų spektrai gali būti sujungti, nes susiję. Tačiau ir geriausios krizès valdymo strategijos, taikytos kitoje šalyje, negalima nukopijuoti, ją reikia modeliuoti įvertinus vietos situaciją. Pasaulyje taikomi ivairūs statybos ir nekilnojamojo turto sektoriaus ir jų atskirų segmentų krizės analizės, prognozavimo, modeliavimo ir valdymo metodai bei modeliai. Statybos verslo varomoji galia tiesiogiai priklauso nuo bankų kreditavimo, nes bet koks šios srities projektas yra ilgalaikis ir išaldo nemažai lěšų. Todèl dažnai, norint apibūdinti rinka, analizuojami finansai, paskolų politika, įmonių mokumo lygis ir pan. (Regan et al. 2011; Sriraj, Khisty 1999).

Demyanyk ir Hasan (2009a) atliko keleto statistinių modeliu, taikomų finansų krizei ir bankų veiklai prognozuoti, apžvalgą. Daugumoje centrinių bankų veikia ivvairios išankstinio perspejjimo sistemos (Early Warning Systems EWS) kontroliuojančios bankų riziką. Tačiau per pastaruosius du dešimtmečius pasikartojusios bankų krizès - tokios kaip Azijos krizé, Rusijos bankų krizè ir Brazilijos bankų krizé - parodè, kad bankininkystès apsauga nèra lengva užduotis.

Šiai užduočiai spręsti gali būti taikomas operacijų tyrimas. Tai sudètinga tarpdisciplininè priemoné, kuris sieja modeliavima, statistinius duomenis ir algoritmus. Ja grindžiami metodai, kuriais siekiama rasti optimalius arba artimus optimaliems sudètingų problemų ir situacijų sprendimus. Daugelis operacijų tyrimo metodų turi funkcijų, panašių i tas, kurios būdingos žmogaus smegenims. Pavyzdžiui, neuroniniai tinklai (Neural Networks NN) yra plačiausiai naudojamas metodas. Jis turi matematini algoritma, ir elementus, kurie imituoja žmogaus nervų sistemos biologinius neuroninius tinklus. Modelyje naudojamos netiesinès funkcijos aproksimacijos priemonès, tikrinančios ryši tarp nepriklausomų (aiškinamuju) ir priklausomų (kuriuos reikia paaiškinti) veiksnių. Metode imama susijusi dirbtinių neuronų grupe ir apdorojama su jais susijusi informaci- 
ja, taikant vadinamaji ryšių metodą (Connectionist Approach), kai tinklo vienetus sujungia informacijos srautas. Modelio struktūra keičiasi priklausomai nuo išorinès arba vidinès informacijos, kuri pereina per tinklą mokymosi etapo metu.

Siekiant geriau numatyti ir analizuoti nemokumą ir krizes, statistiniai metodai dažnai taikomi kartu su intelektiniais metodais, idant modelis duotų geresnių rezultatų. Daugeliu apžvelgtų atvejų modeliai, kuriuose naudojami operacijų tyrimo metodai atskirai arba kartu su statistiniais metodais, padeda geriau numatyti krizę nei vien statistiniai modeliai. Pastaruoju metu itin išpopuliarejo hibridinès intelektinès sistemos, kuriose derinami keli atskiri metodai.

Empiriškai nagrinejjant antrinių (Subprime) paskolų krizę (Demyanyk, Van Hemert 2009b) naudotas trukmès (laiko) statistinis modelis, kuris leidžia ivvertinti vadinamają nekilnojamojo turto paskolų išgyvenimo trukmę, t. y. kiek laiko, kaip tikimasi, paskola liks einamoji iki pirmojo nusižengimo (praleisto mokejjimo) arba nemokumo, su sąlyga, kad anksčiau nusižengimo arba nemokumo nèra buvę. Be to, modelis leidžia ịvertinti atskiras paskolos ir skolininko charakteristikas bei makroekonomines sąlygas. Atsižvelgiant i apskaičiuotus rezultatus, kredito taškų, kaupiamojo paskolos ir vertès santykio, nekilnojamojo turto paskolos normos ir namo kainos augimo ribiniai poveikiai yra didžiausi, ir šie veiksniai yra svarbiausi aiškinant antrarūšių paskolų rezultatų skerspjūvio skirtumus. Tačiau tas pats modelis rodo, kad antrarūšių nekilnojamojo turto paskolų rinkos krizę lèmè ne būsto kainos JAV kritimas. Krizè, prieš pasirodant jos ženklams, brendo bent šešerius metus iš eilès. Antrarūšių nekilnojamojo turto paskolų kokybẻ bent jau nuo $2001 \mathrm{~m}$. kasmet monotoniškai prastejjo; tačiau tokią eigą slèpé namų kainos augimas. Kitaip tariant, nebuvo taip, kad paskolų kokybė gerokai suprastejjo staiga, prieš pat finansinių nemokumų bangą - kokybe buvo bloga ir kasmet blogejjo. Tą prastesnę kokybę galima buvo pastebėti tik èmus lètèti procesams būsto rinkoje - kai blogos paskolos negalèjo pasislèpti už didžiulio namų vertès augimo ir kai blogų paskolų nebuvo įmanoma refinansuoti.

Intelektinio modeliavimo metodus, taikomus atliekant operacijų tyrimus, galima taikyti numatant krizes ir bankų žlugimus. Dirbtinių neuroninių tinklų modelius galima naudoti prognozuojant neveiksnių paskolų dali visų paskolų portfelyje (Celik, Karatepe 2007), kapitalo dali turte, pelno dali turte ir nuosavo kapitalo (equity) dali turte. Kitu atveju (Alam et al. 2000) apytikslio grupavimo ir savitvarkiai (Fuzzy Clustering and Self-Organizing) neuroniniai tinklai - tai klasifikavimo priemonès, leidžiančios nustatyti galinčius žlugti bankus.

Analizuojant bankų krizes logistinès regresijos (Logistic Regression-Logit) ir signalo išskleidimo (Signal Extraction) metodais (Davis, Karim 2008), galima palyginti statistinius ir intelektinius metodus. Nustatyta, kad ịvertinimo modeliu pasirinkimas turi reikšmés rodiklių charakteristikoms ir krizès numatymui. Logit modelio rezultatai geresni, kai jis naudojamas kaip visuotine EWS, o signalų išrinkimas yra tinkamesnis kaip šalies poreikiams pritaikyta EWS. Išnagrinèję 
12 makroekonominių, finansinių ir institucinių kintamujų, autoriai nustatè, kad Logit rezultatai yra geriausi tarp visu visuotinių EWS, skirtu JAV ir Jungtinei Karalystei. Tačiau šio modelio, kaip ir daugelio kitų, galimybės numatyti krizes labai mažos.

Tarp statistinių metodų, analizuojančių ir numatančių bankų žlugimus, diskriminantinè analizè (DA) daugelị metų buvo pagrindinis metodas (pvz., Haslem et al. 1992). DA sudaro trys pogrupiai: linijinis, daugiavariantis ir kvadratinis. Vienas DA trūkumas, kad jai reikia normalaus regresorių pasiskirstymo, kai regresoriai nèra normaliai pasiskirstę, galima taikyti didžiausios tikimybès metodus, tokius kaip Logit. DA - tai priemonè, leidžianti analizuoti skerspjūvio duomenis. Jei reikia analizuoti laiko eilučių duomenis apie banko, firmos arba paskolos nemokumą, vietoj DA modeliu galima taikyti pavojaus arba trukmès analizès modelius.

Yra mėginimų kurti integruoto ankstyvojo ispejjimo sistemas (Integrated Early Warning System IEWS) (Canbas et al. 2005), kurios gali būti naudojamos kaip pagalbinès sprendimų prièmimo priemonès bankų patikrinimo ir priežiūros procese, nustatant bankus, patiriančius rimtų problemų. Tyrime naudoti imties ir kintamujjų rinkiniai iš 40 privačių Turkijos komercinių bankų (1997-2003 m. 21 bankas patyré nesėkmę). Daugiamate statistinė technika (pagrindinių komponenčių analizè), kuri buvo naudojama ieškant pagrindinių finansinių bankų rodikliu, ir DA, Logit ir Probit modeliai buvo sujungti kuriant IEWS. Tyrimo rezultatai rodo, kad sèkmingai taikant IEWS bankų priežiūrai ilgalaikèje perspektyvoje įmanoma išvengti didelių banko restruktūrizavimo sąnaudų.

Atgalinio ryšio neuroninių tinklų (Back-Propagation Neural Netrowks BPNN) modelis yra daugiasluoksnis. Pirmaji sluoksni sudaro ivesties sekcijos, vidurini sluoksni - paslëptosios sekcijos, o paskutini - išvesties sekcijos. Kiekvienas aukštesnis sluoksnis gauna ịvesties duomenis iš žemesnio lygio sekcijų, o išvesties duomenis perduoda virš jo esančio sluoksnio sekcijoms. Svarbus BPNN bruožas - paslèptojo sluoksnio sekcijų sugeneruotos klaidos apskaičiuojamos grąžinant klaidas, esančias išvesties duomenyse, kuriuos perdavė atitinkamo jo sluoksnio lygiai. BPNN ịveikia vienasluoksniam tinklui būdingus klasifikacijos apribojimus, ir tai yra vienas dažniausiai taikomų metodų nagrinejjant klasifikavimo bei numatymo problemas.

Pavyzdžiui, BPNN modelis buvo pritaikytas tiriant Teksaso bankų žlugimo tikimybes (Tam 1991), nagrinejjant jų padèti prieš metus ir prieš porą metų iki žlugimo. Naudodamas CAMELS kriterijais (kapitalo adekvatumas, turto kokybe, vadovu patirtis, uždarbio patikimumas, likvidumas ir jautrumas rinkos rizikai) pagristus įvesties kintamuosius, autorius nustatè, kad pagal numatymo tikslumą BPNN nurungia kitus metodus, tokius kaip DA ir Logit.

Tirdami galimą kreditavimo rizika, Taivanio mokslininkai Chen ir Shih (2006) akcentavo šios rizikos reitingavimo svarbą visiems dalyviams - emiten- 
tams (pinigų ir vertybinių popierių leidejjams), investuotojams, rinkos priežiūros institucijoms ir tarpininkams. Jie susitelke i emitento kredito reitinga, kuris nusako bendrą emitento pajègumą vykdyti savo finansinius i̇sipareigojimus visa apimtimi ir laiku, tyrimu taikant pagrindinių komponenčių (Support Vector Machine SVM) metodą. Tirti beveik visu (išskyrus tris) Taivanio bankų duomenys. Bandyta praplèsti vertinamų duomenų kiekị ir prailginti iki trejų metų vertinamaji laikotarpi (iprastai modeliuojant vertinami vieneri metai). Autoriai pažymi, kad naudojant papildomus kintamuosius, tokius kaip akcijų rinkos informacija ir pagrindinių akcininkų, valdančių daugiau kaip $10 \%$ išleistu akcijų, finansinę parama, bendras modelio tikslumas gali padideti iki 84,62 \%. Informacija apie Vyriausybès turimas akcijas kredito reitingų tikslumą padidinta iki 80,77\%. Praplèstas finansinių rodiklių duomenų laikotarpis nuo vienerių iki trejų metu sumažino tikslumo normą. Tai reiškia, kad būtent paskutinių metų finansiniai duomenys yra labai svarbūs priimant sprendimus.

Australijos mokslininkai McKibbin ir Stoeckel (2009), taikydami dinamiškų atsitiktinumų bendrosios pusiausvyros (Dynamic Stochastic General Equilibrium DSGE) modeli, tyre kaip vienos ar kitos šalies vyriausybès pasirinktos makroekonominès priemonès gali padèti greičiau ar ne taip greitai ịveikti globalinès finansų krizès padarinius atskirose šakose. Buvo pasirinkti šeši ūkio sektoriai (energetika, kasyba, žemės ūkis, ilgalaikio vartojimo prekių gamyba, trumpalaikio vartojimo prekių gamyba ir paslaugos) bei 15 šalių/regionų (JAV, Japonija, JK, Vokietija, ES, Kanada, Australija, OECD šalys, Kinija, Indija, likusi Azija, Lotynų Amerika, likusios lotynakalbès šalys, Rytų Europa ir buvusi Sovietu Sajunga, OPEC). Sprogęs nekilnojamojo turto burbulas Jungtinèse Amerikos Valstijose pakeite tiek namų ūkių, tiek verslo požiūrị i r riziką. Finansinio aktyvumo nuosmukis lèmé staigų nedarbo augimą ir sukèlè politini atsaką. Norint apsaugoti vidaus pramonę naudojamos ịvairios priemonès nuo subsidijų iki sienos apsaugos. Tyrimo rezultatai parodè, kad krizès efektas pasaulinèje rinkoje nebūtų toks dramatiškas, jei kilusi rizika kitoms šalims nebūtų buvusi pervertinta. Tai lèmé dideli produkcijos ir prekybos susitraukimą. Namų ūkiai nerimaudami dèl ateities pajamų, riboja vartojimo mastą. Dèl lūkesčiu pasikeitimo investicijos susitraukia iki ketveriu ankstesnių metų lygio, o grį̌imas gali trukti net dešimtmetị. Fiskalinès priemonès turi tik laikiną teigiamą poveikị.

Iacoviello ir Neri (2008), taikydami Bajeso metodus, modeliavo JAV duomenis nuo $1965 \mathrm{~m}$. I ketvirčio iki $2006 \mathrm{~m}$. IV ketvirčio, norèdami nustatyti kiekybinę būsto rinkos svyravimų priklausomybę nuo verslo svyravimų. Modelis išryškino rinkos nelankstumo požymius, kuriuos daugiausia lemia: pirma, didelę kainos augimo dalị sudaro lèta technologinè būsto sektoriaus pažanga; antra, gyvenamujų namų investicijos labai jautrios pinigu politikai; trečia, nekilnojamaji turtą veikia išaugęs vartojimo mastas, kuris laikui bėgant tapo reikšmingas. 
JAV Komercijos departamento vertinimu, $2007 \mathrm{~m}$. visas viešasis ilgalaikis turtas sieke apie 8,2 trilijono dolerių. Privatus negyvenamasis ilgalaikis turtas 15,5 trilijono dolerių. Viešujų investicijų i infrastruktūrą apimtis $1965 \mathrm{~m}$. sieké net $5,5 \%$ per metus, o nuo $1980 \mathrm{iki} 2007 \mathrm{~m}$. šis augimas vidutiniškai sudare tik 2,3 proc. per metus. Heintz et al. (2009) modeliavo tikètiną ekonomini poveiki nuo viešujų investicijų padidinimo tokiose infrastruktūros srityse kaip transportas, vandens sistemos, energetika ir valstybinių mokyklų pastatai. Komercijos departamento modelis parodè, kad, skyrus milijardą dolerių infrastruktūrai vystyti, būtų gauta 18000 darbo vietų, o parèmus ta pačia suma namų ūkius mokesčių mažinimu, būtų sukurta daugiausia 14000 darbo vietų, nes dalis lèšų nukeliautų importui pirkti. Autoriai apskaičiavo būtinų (bazinių) investicijų i bendro naudojimosi infrastruktūrą poreiki penkeriems metams - $87 \mathrm{mlrd}$. dolerių kasmet, iš kurių apie $54 \mathrm{mlrd}$. turètų ateiti iš valstybès ir $33 \mathrm{mlrd}$. būtų privačios investicijos. Palyginimui jie sudare aukščiausių investicijų poreikio penkerių metu programą, kurioje numate $148 \mathrm{mlrd}$. doleriu per metus. Šioje programoje 93 mlrd. turètu ateiti iš viešojo sektoriaus, o $55 \mathrm{mlrd}$. - investicijos iš privataus sektoriaus. Bazinės infrastruktūros programa sukurs maždaug 1,6 mln. naujų darbo vietų Jungtinèse Amerikos Valstijose, o aukščiausių investicijų programa sukurs maždaug 2,6 mln. darbo vietų. Didžiausia jų dalis, apie 40 proc., tenka statybos sektoriui. Tai reikštų, kad apie 640000 darbo vietų pagal bazini scenarijų ir 1 milijonas - pagal aukščiausių investicijų programą.

Jungtinè mokslininkų grupè: Gupta (Pretorijaus universitetas), Kabundi (Johanesburgo universitetas) ir Miller (Konektikuto universitetas) (2009) nagrinèjo, kaip nagrinejjami dideli duomenų kiekiai prognozuojant būsto kainų dinamiką dvidešimtyje JAV valstijų. Jie taike standartini vektorinès autoregresijos (Vector Autoregressive VAR) ir Bajeso vektorinès autoregresijos (Bayesian Vector Autoregressive BVAR) modelius, padidindami juose kriterijų skaičių arba praplèsdami laikotarpius. Iš 308 makroekonominių rodikliu, 172 kintamieji nusako nekilnojamojo turto rinkos gyvybinguma, 80 susiję su kainomis bei infliacija, o 56 skirti apibūdinti pinigu sektorių. Patikrinimui buvo pasirinkti du laikotarpiai: pirmasis nuo $1976 \mathrm{~m}$. pirmojo ketvirčio iki $1994 \mathrm{~m}$. ketvirtojo, o antrasis - nuo 1995 m. pirmojo ketvirčio iki 2003 m. ketvirtojo. Autoriai pažymi, kad geografinis artumas kaimyninių valstijų būsto rinkos beveik neveikia, o didmiesčių gretimų rajonų rinkų svyravimai pastebimai susiję. Mokslininkai teigia, kad regionų būstų rinkos veikia viena kitą: namų pirkejjai arba statytojai reaguoja i kainų lengvatas. Pirkejo apsisprendimą gali lemti skirtinga motyvacija, tokia kaip: 1) migracija tarp valstijų dèl darbo vietų arba išejjimo i pensija; 2) nuosavo kapitalo perskaičiavimas, vyresni gyventojai pensijoje gali sau leisti parduoti turimą nekilnojamaji turtą ir pirkti kitoje valstijoje dèl mažesnès jo kainos; 3) investuotojai būsto investicijų fondų lèšas stengiasi paskirstyti erdvèje, kad jas apsaugotu. 
Ivairių autorių moksliniuose straipsniuose tiriamas ekonominès krizès poveikis statybos procesui bei ieškomi būdai jos poveikiui mažinti (Gibson et al. 2003; Wang et al. 2000; Nafday 2011; Nehdi 2002; Rojas 2000; Gilbert, DeVilbiss, 2010; Green, 2009; Arciszewski, 2006).

Kanados internetineje erdveje (Construction Sector Council 2010) veikia statybos prognozavimo sistema, kaupianti statybos organizaciju gyvenamosios ir negyvenamosios statybos investicinès veiklos, darbo jègos pasiūlos bei paklausos duomenis nacionaliniu, provincijų ir regionų lygiu. Labour Market Information (LMI) programa skirta pateikti ir prognozuoti statybos amatu bei profesijų atstovams darbo pasiūlos ir paklausos tendenciją. Ši programa naudojama nuo $2004 \mathrm{~m}$. ir grindžiama išsamiu pramonès prognozavimo modeliu. Naudojant duomenis surinktus iš 14 Kanados regioninių rinkų, atsižvelgiant ị tokius veiksnius, kaip ekonominė statybos verslo aplinka, investavimo perspektyvos, sistema prognozuoja darbu apimtis statybos pramonejje; darbo jègos prisitaikymą prie paklausos pokyčių; itampą darbo rinkoje ir naujai kylantị darbo jègos poreiki.

\subsection{Imonès, dirbančios statybos srityje, veiklos elementai}

Vadyba - strategijos rinkoje pasirinkimas ir planavimas. Visame pasaulyje statybos verslas kinta, iš gamybos vis labiau panašèdamas i klientu aptarnavima, paslaugu teikimą. Smulkiojo ir vidutinio verslo veikloje svarbi vieta tenka amatui. Ši sąvoka buvo tarsi primiršta. Tačiau amatas kaip specialių žinių ir igūdžių ivaldymas kurioje nors srityje yra verslo pagrindas. Vidutinio masto verslininkas gali ir nežinoti visų savo amato ypatybių, tačiau smulkusis verslininkas privalo būti geru savo srities amatininku. Be to, jis turi gebèti dirbti su nedideliu kolektyvu, turèti teisinių, apskaitos, finansinių ir komercinių žinių.

Gaminti tik tam, kad būtu gaminama visiškai neprasminga. Bet kokia gamyba atsiranda dèl visuomenès poreikio vienam ar kitam produktui. Poreikis, paklausa yra impulsas imonei susikurti ir egzistuoti. Paklausa lemia rinka. Kadangi statybos produkcija: pastatai, statiniai, infrastruktūros objektai ir pan., ši produkcija yra brangi, ilgai gaminama ir visada unikali (net tokio paties plano gyvenamojo namo statyba skirsis nuo greta stovinčio, nes bus skirtingos grunto salygos). Tad statiniai labai retai (išskyrus butus) statomi laisvam pardavimui. Dažniau jie statomi tik tuomet, kai su konkrečiu statytoju (užsakovu) sudaroma rangos sutartis. Tokių sutarčių visuma sudaro įmonès gamybos programą: ką, už kiek ir kada reikia pastatyti.

Imonè gali imtis igyvendinti sutartis tik tuomet, kai turi tam visas galimybes. Galimybès - tai gamybos ištekliai, kuriuos sudaro žmonès, finansai ir gamybos priemonès. Gamybos ištekliai turi atitikti gamybinę programą, todèl įmo- 
nès, atsižvelgdamos i paklausa, turi turèti gamybos programą: kaip bus statoma ir kokių priemonių reikès.

Rinkos segmentavimas sukonkretina tolesnes rinkodaros priemones, pirmiausia paklausos tyrimo objektą. Geras segmentavimo pagal užsakovų kategoriją pavyzdys gali būti statybų bendrovès „ŽIA valda real estate“ patirtis: prieš rengiant gyvenamojo namo projekta, buvo gerai išanalizuoti vartotojų poreikiai, ir atkreiptas dèmesys $\mathfrak{i}$ tai, kad prie statomų daugiabučių labai trūksta erdvès. Todèl nuspręsta įrengti parką ant stogo. Taip pat numatomos prabangios apdailos medžiagos: panoraminiai liftai, padidintos garso izoliacijos fasadinès stiklo sistemos su saulès energijos kontrolès paviršiumi. Remiantis Info.lt informacija, paskelbus apie galimybę pirkti butus „Kabančiuose soduose“, per labai trumpą laiką - vieną dieną - buvo rezervuota 90 iš 120 butų (AB ,ŽIA valda“ 2008).

Taigi gamyba priklauso nuo paklausos. Todèl svarbiausia turèti užsakymų, turèti rinką. Žinios apie tai, kada, kur ir kokių užsakymų realiai galima tikètis, sudaro i̇monès išlikimo pagrindą. Norint apsirūpinti pakankamu užsakymų kiekiu, reikia turèti plačią klientūrą. Plati klientūra - tai dar ir pasirinkimo teisè. Plačią klientūra garantuoja geras i̇monès vardas. Ji galima pelnyti tik geru darbu, dèmesiu vartotojui. Statybos klientūra ypač jautri neigiamiems atsiliepimams, gandams. Statybinę produkciją - statini - nusako trys jos svarbiausi požymiai: kaina, kokybè ir statybos laikas. Kad statiniai (ar atliekami darbai) galètų išlaikyti konkurenciją, būtina nuolat tobulinti jų architektūrinius-konstrukcinius sprendinius ir statybos technologinius procesus.

Lietuvos Respublikos ūkio juridiniai ir fiziniai asmenys turi teisę savo iniciatyva bei savo lěšomis steigti susivienijimus, bendrijas, asociacijas ir kitus imonių bei organizacijų derinius. Valstybè nereguliuoja jokio ekonominio proceso, kurio savireguliavimas yra efektyvesnis. Lietuvos Respublikos valstybinès valdžios ir valdymo organai valdo Respublikos ūki naudodami ekonomines priemones: mokesčius, bankų palūkanas, valstybines investicijas bei kontraktus, socialines, ekologines-ekonomines ir kitas priemones. Svarbiausias kapitalinès statybos uždavinys - kurti ir sparčiai atnaujinti pagrindinius fondus, skirtus visuomeninei gamybai plètoti ir socialiniams uždaviniams spręsti, kardinaliai didinti statybos efektyvumą. Numatoma padidinti kapitalinių įdejjimų i ūkị efektyvuma, tobulinti reprodukciją ir technologinę struktūrą. Koncentruoti materialinius, finansinius ir darbo išteklius pirmiausia veikiančioms įmonèms techniškai modernizuoti ir rekonstruoti, taip pat statyti objektams, lemiantiems mokslo ir technikos pažangą bei sprendžiantiems socialinius uždavinius. Garantuoti, kad objektai būtų statomi ir atiduodami naudoti atsižvelgiant į norminius terminus, mažinamas vienu metu statomų objektų skaičius ir statybos kaina, iš esmès bus pagerinta statybos kokybè.

Vadybą galima apibūdinti kaip įmonès derinimąsi prie aplinkos sąlygų. Ši išorinė aplinka skiriama ị tris lygius: 
- bet kokio imonès igyvendinamo projekto lygis (vidinių išteklių valdymas ir perskirstymas);

- konkrečios įmonès lygis (lokalizacija, rinka, konkurencija);

- makroekonominis lygis (ekonominè valstybès politika).

Turintis savo verslą klientas nori bendrauti su vienu partneriu. Todèl statybų rinkoje isigali pagrindinio rangovo ir subrangovo sąvokos. Pagrindinio rangovo paslaugas teikianti imoné teikia savo klientams visą statybos paslaugu paketą. Klientas, rinkdamasis statybos įmonę, kelia ne tik kokybès ir kainos reikalavimus, bet vertina ir jo verslo keliamų tikslų suvokimą. Statybos paslaugų paketas suvokiamas kaip visuma nuo kliento turimo verslo tikslų sampratos, projektavimo, statybos vietos paruošimo iki statybos vykdymo ir statinių eksploatavimo. Tai nereiškia, kad pagrindinis rangovas pats vykdo projektavimo darbus. Tiesiog, kuo anksčiau jis įsitraukia i ši procesa, tuo tiksliau gali būti padaryti pakeitimai, parinktos geriausios alternatyvos, patenkinti kliento poreikiai.

Kokybès vadyba - tai koordinuoti veiksmai, kreipiantys ir valdantys organizacijos veiklą, susijusią su kokybe. Ji apima kokybès politiką ir tikslus, kokybès planavima, valdymą (kontrolę), užtikrinimą ir jos gerinimą. Sudètinè kokybės gerinimo dalis yra nuolatinis gerinimas (Yasamis et al. 2002).

Atlikus Švedijos statybos sektoriaus tyrimą (Josephson et al. 2002) nustatyta, kad projektuojant padarytos klaidos ir juc taisymas pabrangina statybą 4,4 \%, o igyvendinant atsirandantys trūkumai ir vèlavimas $-7,1 \%$. Autoriai siūlo: visoje šakoje padidinti investicijas i profesijos mokymą gerinant darbo jègos meistriškuma; igyvendinti kokybès garantijų sistemą; pagerinti komunikaciją tarp rangovų ir tiekejjų; tobulinti sutarčių sudarymo mechanizmą, siekiant sumažinti būsimų pakeitimų kiekị; diegti lygiagretaus projektavimo sąvoką mažinant projektavimo laiką ir projekto kainą; nesėkmių analize siekiant pagerinti sprendimų prièmimą ir pakeitimu būsimuose projektuose mažinima; igytą patirtị diegti vadybos ir kontrolès etapuose.

Australijos statybos šakos vystymo agentūros tyrimais (1995). statybos klaidos padidina galutinę statybų kainą iki $10 \%$. Tad ịvertinus metinę statybos apyvarta, kuri $1994 \mathrm{~m}$. sieke 43,5 mlrd. Australijos doleriu, tai kainos korekcija gali sudaryti 4,3 mlrd. Australijos doleriu per metus. Neskiriant pakankamo dèmesio statybos kokybei, projektų koregavimas arba trūkumų šalinimas tapo vietinès statybos šakos ypatybe. Tyrimai (Cnuddle 1991) parodè, kad galutinè statybos kaina gali pabrangti nuo 10 iki $20 \%$ visos projekto kainos. Be to, buvo nustatyta, kad $46 \%$ nukrypimų nuo kainos jau užprogramuota projektuojant, o apie $22 \%$ - statybos metu.

Suomijos mokslininkai (Naaranoja, Uden 2007), tyrinèję viešų statybos projektų igyvendinimą, išskyrè didžiausias problemas ir nuostolius, susijusius su projektų užbaigimu. Jie išskyre trūkumus, būdingus: sprendimų prièmimo procesui; laiko planavimui; statybos reguliavimo atnaujinimui; vartotojų suvokimui, 
ko jiems reikia; projekto dalyvių pasitikejjimui vieni kitais; rizikos vertinimui; IT naudojimui ir vadybos persitvarkymui.

Faktas, kad vienas trečdalis iš 500 sèkmingų kompanijų iš 1970-ųų sąrašo neatsirado analogiškame 1983-ujų sąraše, rodo kaip nesugebejjimas prisitaikyti prie kintančių sąlygų, neryžtingumas ir blaškymasis sukelia organizacijos žlugimą. Kaip aktyvumas prailgina žmonių gyvenimus, taip $66 \%$ organizacijų, kurioms grèsè išnykimas, išliko daugiau kaip po dešimtmečio, nes keitèsi ir mokèsi (Montuori 2000).

\subsection{Galimi reagavimo ị bendrą ekonominị nuosmuki būdai (patirtis)}

Europos statybos rinka tikrai nėra homogeniška. Kiekvienos valstybės narès dabartinè situacija ir perspektyvos priklauso nuo jos pradinès padèties (atsižvelgiant i poreikius, demografines tendencijas, pagrindinius ekonomikos principus ir pan.), nuo to, ar neseniai buvo nekilnojamojo turto rinkos korekcijuc nuo konkretaus šalies ūkio atvirumo finansinès ir ekonominès krizès poveikiui, o galiausiai nuo to, kokios ilgalaikio gaivinimo priemonès bus sékmingos ir sékmingai veiks statybos sektorių (Detemmerman 2009).

Švedijos statybos bendrovès, susidūrusios su 1990-ujų ekonomikos krize, nuejjo imonių stambinimo (stipresniosios supirko bankrutuojančias) bei išèjimo ị užsienio rinkas keliu (Economic sectors: Construction 2008). Didžiulès statybos bendrovès iki trečdalio savo gamybos iškeelè ị kitas šalis (daugiausia į JAV).

Belgijos vyriausybè, norėdama paremti statybos pramonę krizès akivaizdoje, laikinai (vieneriems - 2009-tiems - metams) leido taikyti lengvatini PVM mokesti, sumažindama ji statybos sektoriuje nuo $21 \%$ iki $6 \%$. Šis tarifas gali būti taikomas tiek statomiems, tiek jau pastatytiems būstams. Tačiau keliama ir apribojimų: tai turi būti pirmas ịsigyjamas gyvenamasis būstas ir naudojamas kaip pagrindinè savininko gyvenamoji vieta mažiausiai penkeriems metams. Mažesnis mokestis iki 2010 metu gali būti taikomas renovacijai, kuri taip pat turi atitikti tam tikras sąlygas. Sumažintas PVM netaikomas darbams, tiesiogiai nesusijusiems su gyvenamų pastatų statyba, pavyzdžiui, baseinai, pirtys, teniso kortai ir panašiai (Die Wirtschaftskammern Österreichs 2009).

Tiek statybos praktikoje, tiek atliekant tyrinejjimus paskutiniu metu skiriamas ribotas dèmesys logistikos temai statybos aikštelèje, nepaisant to, kad gali būti sutaupyta daug lèšų optimizuojant tokius su statyba susietus procesus, kaip svorio vieneto ar urminis transportavimas. Vykdydamas mokslinio tyrimo projektą AiF (Arbeitsgemeinschaft industrieller Forschungsvereinigungen „Ottovon-Guericke“ e.V. - AiF) Miuncheno technikos universitetas, bendradarbiaudamas su gamybos partneriais ir atsižvelgiant ị specifines sąlygas, kūrẻ nuotoli- 
nę informacinę sistema, taikomą statybos pramonei, bei atliko ilgalaikius bandymus. Pagrindinis sistemos modulis - ryšys su biuro sistema (SAP), kuriuo perduodami visi realūs duomenys ir naudojami apibendrinimui bei statistiniams skaičiavimams. Vokietijos banko tyrimai aiškiai rodo, kad ateityje statybos srityje nereikia tikètis užsakymų daugejjimo, nes dabartiniai kapitalo įdejjimai keletą metu yra labai žemo lygmens ir jiems būdinga mažejimo tendencija. Vidutinio laikotarpio investicijos i pramoninę daugiaaukštę statybą yra ypač žemo lygmens. Vokietijos gyvenamojoje statyboje papildomai išskiriami pastatų, senesnių nei 50 metų, sanavimo darbai. Dèl to firmos turi ivvertinti kintamus gamybos poreikius organizuojant statybą ir statybos aikštelès logistika, optimizuoti gamybos procesus. Kadangi ilgą laiką statybos šakoje logistika buvo nesureikšminta, yra didelis gerinimo ir taupymo potencialas. Neieinančios i kompetencijos branduoli kai kurios gamybos dalys, pavyzdžiui, statybos mašinos ir transportas, yra tinkami objektai projektų lěšoms taupyti. Transportavimas ị statybos aikštelę yra būtina proceso dalis, sudaranti nemažą visos statybos išlaidų dalį, tačiau ši paslauga visam statiniui (paprastai ir užsakovui) nèra apčiuopiama, nes galutiniame etape nèra matoma. Todèl šią veikla, viena vertus, reikia atlikti su minimaliomis išlaidomis, kita vertus, kokybiškai. Transporto parko išlaidų taupymo galimybe - tai transporto priemoniu ir visos administracijos nuoma. Ji gali būti ir nuostolinga dèl mažo lankstumo ir priklausomybès nuo paslaugos teikèjo, be to, daro mažą i taką kokybei. Alternatyvi sistema leidžia optimizuoti transporto priemonių valdymą savame parke, elektroniniu būdu kaupti duomenis, reikalingus planavimui ir transportavimui. Bet, noredama apdoroti duomenis, firma turi adaptuoti programinę irangą savo poreikiams (Günthner et al. 2007).

Charkove (Ukraina) dirbanti didžiulè investicinè statybos kompanija „Avantaž“ jungia statybinių medžiagų ir gaminių gamybos, statybos, nekilnojamojo turto vystymo, priežiūros ir valdymo įmones. Joje dirba apie 2850 darbuotojų. Stengdamasi išvengti finansinès krizès padarinių, kompanija èmèsi plèsti nekilnojamojo turto eksploatavimo ir valdymo paslaugas. Be to, užsibrėžè tikslą iki $2009 \mathrm{~m}$. pabaigos parduoti savo dali septyniuose objektuose (pvz., prekybos centre „Žukovskij“, kuris projektuojamas; statomuose verslo centruose „Kapitalis“ ir „Brilijantovyi“ bei nuo $2008 \mathrm{~m}$ eksploatuojamame prekybos centre ,Vizit“"), pasilikdama sau rangovo teises. Tuo būdu tikimasi apsirūpinti apyvartinèmis lèšomis ir maksimaliai išsaugoti darbo vietas (UGMK.info 2009).

Ekonomikai spirale smunkant žemyn, statybos įmonèms visiškai natūralu susikoncentruoti i neigiamus dalykus. Pramonès ekspertai sutaria, kad kai kurios imonès ši sunkų laiką naudoja tyrinejjimams, reorganizacijai, prioritetų revizijai (By D. Brown 2008). Siūlomos penkios elgesio sunkmečio laikotarpiu strategijos:

1) apkarpymas: pradedama nuo viso kompanijos biudžeto peržiūrèjimo, tai gali padèti sumažinti išlaidas. Vèliau peržiūrimos skaičiuoklès ir pasirengiama 
apkarpymams. Tai sunkus sprendimas, bet lengviau atleisti vieną darbuotoją, negu pasakyti visai įmonei, kad ji traukiasi iš verslo.

2) rinkodaros parama: sunkiu laikotarpiu kompanijos dažnai ima riboti išlaidas vadybai ir skatinimui. Tai priešingybè to, ką vis dèlto reikètų daryti. Ši priemonè suteiks galimybę sutaupyti tam tikrą pinigu kieki artimiausiu laiku, tačiau tolimesneje perspektyvoje lems rinkos dalies praradimą ir apribos galimybes issigyti naują verslą. Kompanijos vardo išsaugojimas rodo priklausymą statybos pramonei ir įmonès stiprybę bei patikimuma, nepaisant ekonomikos nuosmukio.

3) sutarčių peržiūrèjimas: sulètėjus verslui būtina atidžiai peržiūrèti visas galiojančias sutartis. Iš sutarčių apskaičiuoti draudimo, aptarnavimo automatų buitinèse patalpose išlaidas, peržiūrèti terminus. Paslaugu pardavejjai tokiu metu gali pasiūlyti mažesnes kainas ir palankesnius terminus arba finansavimo būdus, kad išsaugotų verslą.

4) bendravimo su dabartiniais ir buvusiais klientais atnaujinimas: dabartiniai ir buvę klientai gali taip pat blogai jaustis dèl ekonominio nestabilumo. Reikia pasinaudoti tuo ir priminti jiems apie savo pasiūlymus - naudoti savo rinkodaros medžiaga, kreiptis telefonu, suorganizuoti pietus ar golfo diena, skirtą svarbiems žmonėms. Bendravimo atnaujinimas gali suteikti impulsą naujam įmonés verslui.

5) eksperto samdymas: daugelis šių strategijų gali apsieiti be išorinès pagalbos. Ekspertas, galintis įvertinti verslo planą ir pasiūlymus technologiniams procesams tobulinti, gali padèti pakreipti ịvykius naudinga linkme. Firmos dažnai dirba ,things to do" strategija ir nemato bendro proceso vaizdo. Jei neskubama teisingai projektuoti procesus, teigiami rezultatai bus kaip pašalinis produktas.

Didžiojoje Britanijoje vykdyti statybos sektoriaus imonių tyrimai (Bennett 2005) skirti nustatyti geriausiems metodams, kuriuos kompanijos, veikiančios ciklinès ekonominès aplinkos sąlygomis, renkasi pardavinèdamos jų produktus. Autoriaus teigimu, nebuvo jokių reikšmingų ryšių tarp investicijų i oficialias prognozès sistemas. Vienos įmonès stengèsi išlaikyti aukštesnes kainas, kitos bandè derintis prie pakitusių sąlygų, bet tai nelèmé veiklos rezultatų. Jis mano, kad i̇monès turi pasinaudoti smukimu, kad užkariautų rinkos dali ir praplèstų ilgalaikius santykius su klientais. Nepatartina mažinti rinkodaros biudžeto ir siaurinti pradetas igyvendinti programas (1.7 pav.). Tyrimų rezultatai parodé ypač stiprią rezultato priklausomybę nuo strategijos paremtos cikline patirtimi. 


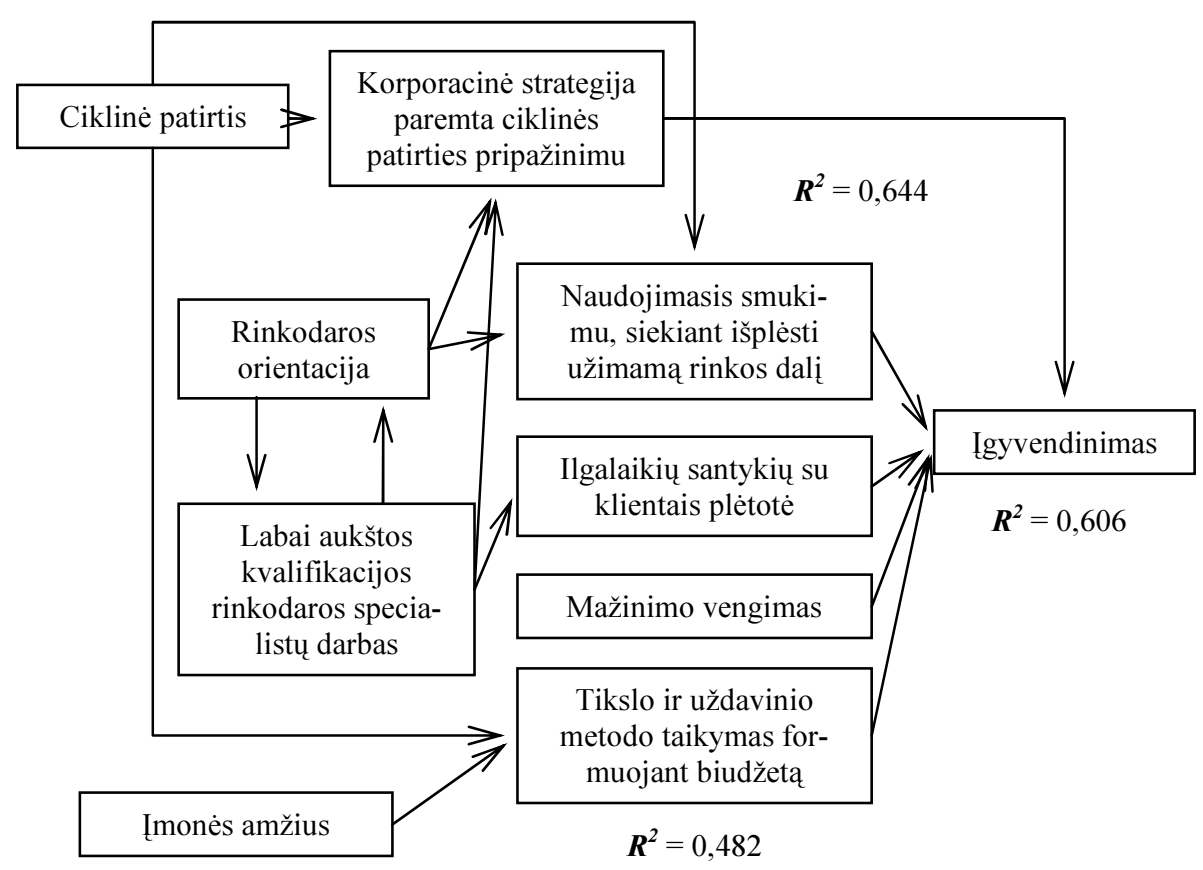

1.7 pav. Imonių rinkodaros modelis smukimo sąlygomis (Bennett 2005) Fig. 1.7. Model of corporate marketing in times of decline (Bennett 2005)

News.World-Estate.com ekspertai pataria potencialiems investuotojams:

1. Apsiginkluoti kantrybe, o investavimui atsiras stulbinamų nuolaidų.

2. Nekilnojamojo turto fondai greičiausiai sureaguos i ekonomikos atsigavimą, todèl geriausia rinktis juos savo investicijoms.

3. Norint atskirti gerą investiciją nuo blogos, reikètų konsultuoti su labai gerais specialistais.

4. Ekonomiškumą ir ekologiškumą remiantys projektai turètų tapti prioritetiniai.

5. Pasiryžus pirkti daugiabučių namų, biurų, viešbučių ir gyvenamujjų namų žemès sklypus, teks juos kurị laiką laikyti.

6. Reikètų rinktis ne pačios geriausios būklès daugiabučius, jei tik yra geras susisiekimas, yra arti prekybos centrų ir vaistinių.

7. Komercinès paskirties rinka turètų atsigauti daug greičiau nei gyvenamosios. Statybos imonès, siekdamos išvengti bankroto, turètų pradèti pardavinèti nebaigtus projektus ypač žemomis kainomis. 


\subsection{Pirmojo skyriaus išvados}

1. Pasaulyje taikomi ịvairūs statybos ir nekilnojamojo turto sektoriaus bei jų atskirų segmentų krizès analizès, prognozavimo, modeliavimo ir valdymo metodai bei modeliai (ankstyvojo perspejimo sistemos, neuroniniai tinklai, laiko eilučių analizè, laike kintančių parametrų modeliai, logistinès regresijos (Logit), signalų sklidimo metodas, diskriminantinè analizė (DA), Probit regresijos modelis, atgalinio ryšio neuroninių tinklų modelis, pagrindinių komponenčiu metodas, dinaminis stochastinis bendrosios pusiausvyros modelis, vektorinès autoregresijos modelis, Bajeso vektorinès autoregresijos modelis ir t. t.). Sèkmingiausi tyrimo metodai, kuriais analizuojamos ir numatomos krizès, yra kompleksiniai, jungiantys tiek statistinius, tiek intelektinius metodus. Statybos ekonominius tyrimo metodus būtina taikyti kainodarai, finansavimo (kreditavimo), i̇sipareigojimų vykdymui užtikrinti.

2. Nagrinejjamam sektoriui itin didelę itaką daro bankų skolinimo politika. Akivaizdus šio faktoriaus pasikeitimas dažnai yra esminè sąlyga krizei atsirasti. Daugumoje šalių paskolų krizès pamatinè priežastis - ydinga ir rizikinga paskolų išdavimo politika. Naudojant aprašomus kompleksinius statybos krizès prognozavimo modelius, atsiranda galimybe įvertinti atskirų paskolų ir skolininkų charakteristikas bei kintančias makroekonomines sąlygas.

3. Net ir geriausi krizių valdymo sprendimai, taikyti kitose šalyse, negali būti aklai nukopijuoti. Jie turi būti parenkami tik pagal konkrečią ekonominę, politinę, teisinę, technologinę, organizacinę, institucinę, socialinę, kultūrinę, psichologinę, švietimo ir aplinkosauginę būklę. Nèra tokio dalyko, kaip bendras krizių valdymo sprendimas, kuris galètų būti taikomas visoms šalims.

4. Pasaulyje taikomi modeliai dažniau taikomi siaurai statybos proceso sričiai (finansams, darbo jègos poreikiui ir pan.). Nèra sukurto statybos projekto ekonominio nuosmukio aplinkoje modelio, kuris kompleksiškai analizuotu visą statybos projekto igyvendinimo cikla, statybos projekte dalyvaujančių bei savo tikslus norinčių igyvendinti suinteresuotu grupių poreikius, ir aplinką veikiančius išorinius mikro-, mezo- ir makroaplinkos veiksnius. Tai reiškia, kad ginamojoje disertacijoje reikia sukurti statybos ekonominio nuosmukio sąlygomis modeli, veiksnių sistemas, išsamiai apibūdinančias statybos projekto igyvendinimą bei rekomendacinę sistemą ir ją pritaikyti praktiniams statybos uždaviniams spręsti. 



\section{2}

\section{Statybos ekonominio nuosmukio aplinkoje koncepcinis modelis}

Skyriuje pateikiamas autorès sukurtas statybos ekonominio nuosmukio aplinkoje koncepcinis modelis. Detaliai aprašomi modelio elementai.

Skyriaus tematika paskelbti du autorès straipsniai (Kaklauskas et al. 2010, 2011).

\subsection{Statybos ekonominio nuosmukio aplinkoje modelio koncepcija}

Esant bendram ekonominiam nuosmukiui, statyba besiverčiantis rinkos dalyvis gali rinktis - reaguoti ar nereaguoti i pokyčius. Statybos verslo ekonominio nuosmukio aplinkoje koncepcinio modelio (2.1 pav.) tikslai yra šie:

- identifikuoti verslo aplinkos salygas;

- konstatuoti aplinkos pasikeitimus;

- nustatyti pokyčių itaką statybos projekto rezultatams;

- ivertinti galimybes reaguoti i kilusias problemas. 


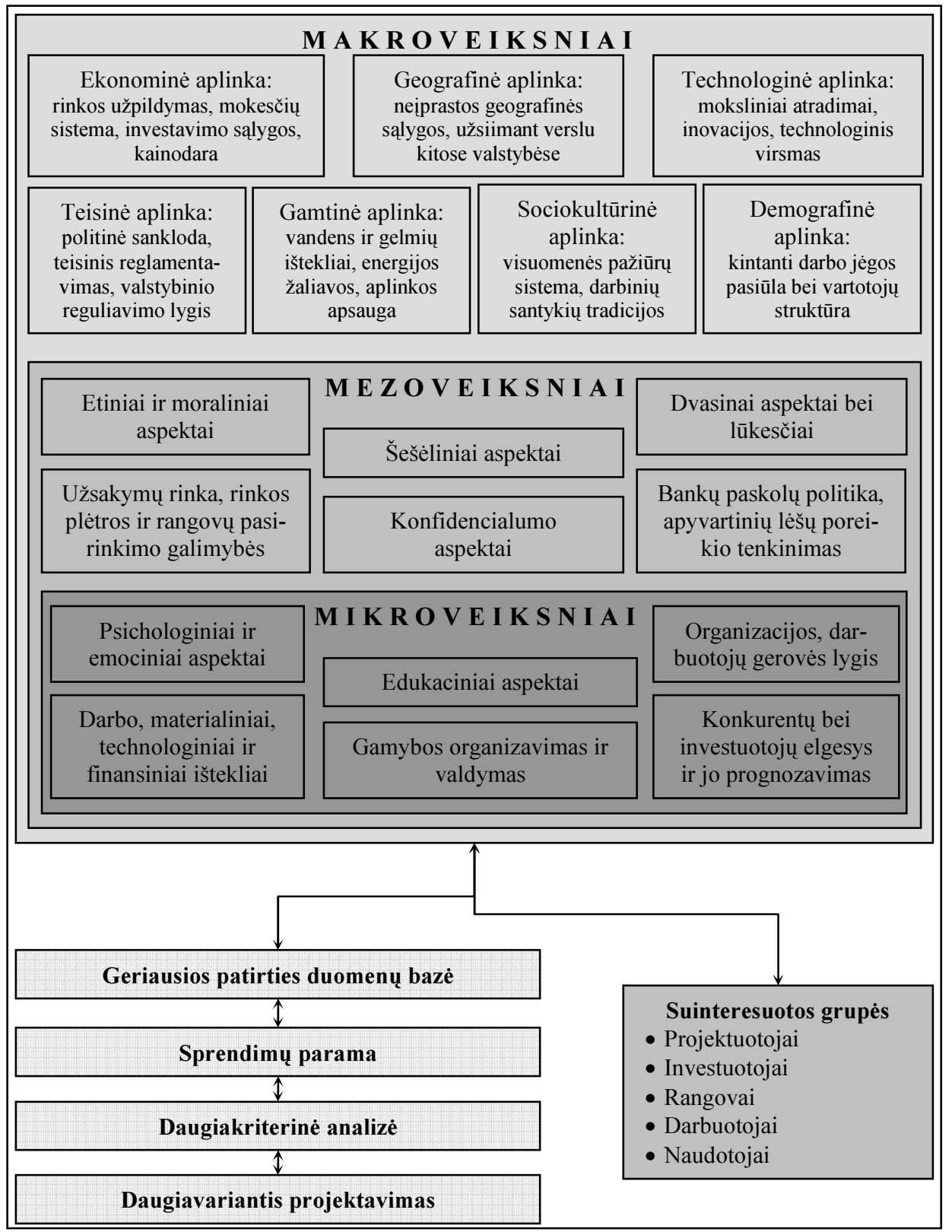

2.1 pav. Siūloma statybos ekonominio nuosmukio aplinkoje modelio koncepcija Fig. 2.1. The suggested model of construction in environment of economic recession 


\subsection{Statybos ekonominio nuosmukio aplinkoje modelio elementų aprašymas}

Valstybė ne tik reguliuoja statybos procesą tiesiogiai nustatydama „žaidimo“ taisykles, bet ir gali daryti įtaką savo finansinès politikos kryptimis. Pavyzdžiui, Švedijoje lengvai gaunamas kreditas, valstybinès subsidijos ir stipri ekonomika antroje 1980-ųų pusejje sukèlé investicijų i statybos sektorių buma, kuris pasieké savo piką 1990 m., kai nauja gyvenamoji statyba siekė 69600 . 1990-uju pradžios krizès metu statyba smuko, ir tai daugiausia lèmé 1990-1991-ujų reforma, kuri buvo nukreipta i valstybinių subsidijų panaikinimą. Ekonomika normalizavosi, tačiau gyvenamoji statyba taip ir liko žemo lygmens - per $1999 \mathrm{~m}$. buvo pastatyta 13000 vienetų. Vèlesnis augimas irgi buvo nežymus: 2000-2001 m. gyvenamosios statybos naujų priimamų objektų skaičius nesieke 20000 . Po 2002-uju stabilizacijos naujos gyvenamosios statybos apimtys augo, ir $2006 \mathrm{~m}$. jau siekè 45300 vienetuc, daugiausia tai lèmè auganti paklausa ir kainos (Economic sectors: Construction 2008).

Imonių ar bendrovių žlugimas - mūsų tikrovès dalis. Jis lemia tiek finansų, tiek kitokio pobūdžio itampą visuomenèje, vyriausybejje, gali paliesti tarptautinę bendruomenę. Nors yra mėginimu prognozuoti ir rekomenduoti veiksmų planą kilus bankroto grèsmei, organizacijǔ žlugimai stichiškai plinta iš vieno sektoriaus i kita, iš vienos šalies i kita. Mokslininkai (Marwa, Zairi 2008) tyre 120 ivairių sričių imonių, žlugusių 2000-2007 m. laikotarpiu, dokumentaciją ir ieškojo vadovų veiklos panašumų ar skirtumų. Iš to skaičiaus buvo šešios dirbusios statybos šakoje. Nurodomas jų žlugimo priežastis galima bandyti išrūšiuoti:

- pirma grupé priežasčiu galètų būti apibūdintai kaip vidinès: buhalterinès klaidos, kalkuliacijos neatitikimas, prasta statybos kokybè, vidinès polemikos, kontraktų kainų išpūtimas, nesąžiningumas projektų vadyboje;

- antra grupé - artimos aplinkos (mezoaplinkos) itaka: nesékmingas susiliejimas, staigi plètra, didelès debitorių sąskaitos, terminų nesilaikymas, didelès eksploatacijos išlaidos;

- trečia grupe - makroaplinkos poveikiai: pardavimo apimties smukimas, konkurencija, finansiniai kliuviniai.

\subsubsection{Makroveiksniai, darantys itaką statybai}

Ekonominę aplinka šalyje tiesiogiai lemia valstybės valdymo organų vykdoma mokesčių ir pinigų, kapitalo judejjimo, investicinès aplinkos, paskolų teikimo ir palūkanų normos politika. Ekonominę aplinką taip pat lemia ir paklausos, pasiūlos, konkurencijos, kainodaros bei kiti ekonominiai veiksniai (Zavadskas et al. 2004). Pagrindiniai ekonominès terpès rodikliai - tai: plètros cikliškumas, infliacija ir nedarbas. Jie daro įtaką kitų rodiklių (tokių kaip BVP kitimas, realios pir- 
kejų pajamos, kaupimo galimybės, mažmeninès prekių kainos, kreditavimo sąlygos) pokyčiams.

Prekių ir paslaugų importas Lietuvoje viršija eksportą (2.3 pav.). Šie rodikliai kinta vienu metu. Pavyzdžiui, 1998 m. dèl Rusijos krizès smuko tiek eksportas, tiek importas (Statistikos departamentas). Tad nenuostabu, kad abi kreivès pradejjo leistis ir 2008 metu pabaigoje, kai užgriuvo bendra ekonominè krizè.

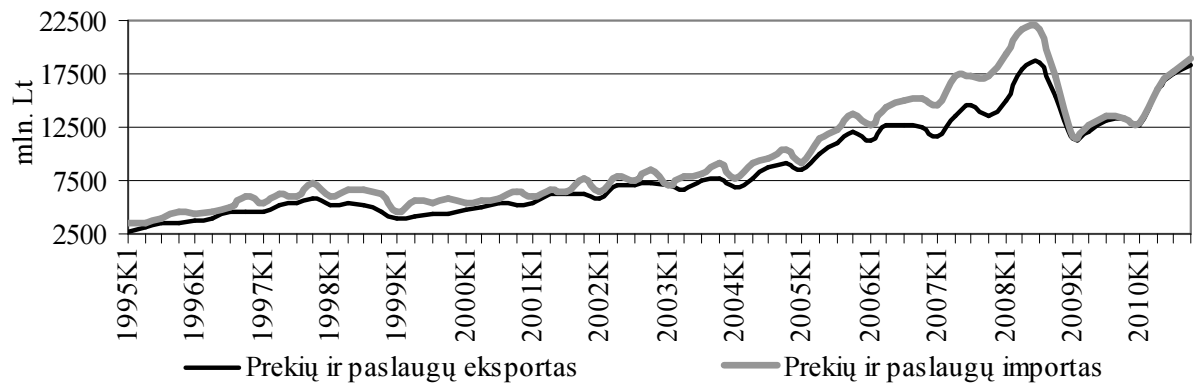

2.2 pav. Lietuvos prekių ir paslaugų importas ir eksportas, milijonais litų to meto kainomis

Fig. 2.2. Lithuanian imports and exports of goods and services, LTL m, at then prices

$2008 \mathrm{~m}$. ketvirtaji ketvirti paskolų prieaugio sumažèjimas, palyginti su prieš metus buvusiu, sudare $15,2 \%$ BVP, o vartojimo ir būsto paskolos iš skolintų léšų nutrūko, sumažèjo verslo investicijų. Paskolų stygius jau sausị 15,9\% sumažino mažmeninę prekybą išskyrus prekybą transporto priemonėmis, apie 60,9 \% smuko investicinių prekių importas bei 14,6 \% sumažejo prekių eksportas (Valstietis.lt).

Finansų ministerija prognozavo, kad $2009 \mathrm{~m}$. Lietuvos bendrasis vidaus produktas (BVP) gali smukti 10,5\% - labiausiai nuo $1993 \mathrm{~m}$. Ministerija $2009 \mathrm{~m}$. gruodi prognozavo, kad $2010 \mathrm{~m}$. šalies ūkis susitrauks 4,8 \%. Pesimistiškesnè prognozė skelbiama, atsižvelgiant ị susiformavusias tendencijas ir pasikeitusią išorès aplinką (Valstietis.lt). Iš tiesų BVP $2009 \mathrm{~m}$. smuko 14,7\%, o 2010 m. pakilo $1,3 \%$.

Tiriant visuomeninių (biurų) patalpų nuomos tendencijas, matoma, kad kainos krito 15-12 \% visose Baltijos šaliu sostinèse. Didžiausias tokių patalpų poreikis ir rinkos plètra buvo prieš 3-5 metus, nuomos sutarčių terminai dažniausiai irgi tokios trukmès. Dèl krizès visame ūkyje nuomininkai nelinkę pratęsti sutarčių arba ieško pigesnių variantų. Šiuo metu aukščiausios klasės biurų patalpas Vilniuje ir Rygoje galima išsinuomoti už 16 eurų ( $\mathrm{m}^{2} / \mathrm{mejn}$.), Taline patalpos šiek tiek brangesnès - 18 eurų (Baltic property market report 2009). Būsto pirkimo/pardavimo sandorių skaičius $2008 \mathrm{~m}$. krito trečdaliu. Naujų butų kainos priklausomai nuo miesto sumažèjo 8-20\%. 
$2008 \mathrm{~m}$. ketvirtaji ketvirti (Statistikos departamentas), palyginti su $2007 \mathrm{~m}$. atitinkamu laikotarpiu, bendrai materialinès vidaus investicijos sumažèjo 2,1\% (2.3 pav.). Dalyje sektorių investicijos išaugo, pavyzdžiui, sveikatos priežiūros ir socialinio darbo istaigose - 46,2\%, kasybos ir karjerų eksploatavimo organizacijose $-28,5 \%$, o investicijos i statybos verslą sumažejo 51,4 \%.

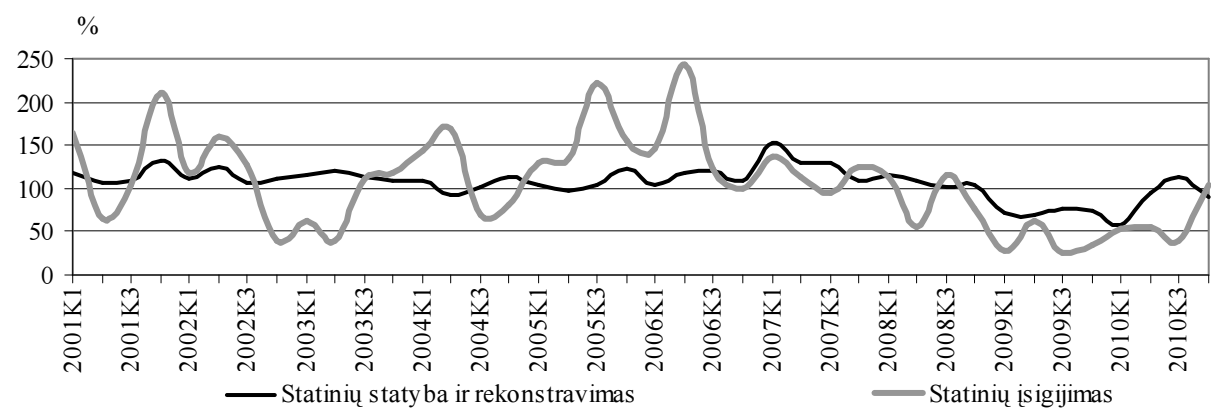

2.3 pav. Materialinės investicijos, palyginti su praejusių metų atitinkamu laikotarpiu

Fig. 2.3. Material investments, compared to the same period previous year

2004-2008 m. Lietuvoje ypač suaktyvejjo bankų paskolų išdavimas. Jas labai lengvai gaudavo ne tik statybos firmos, užsimojusios statyti daugiabučius ar vieno-dviejų butų gyvenamuosius namus, tiek gyventojai, panorę ịsigyti nuosavą gyvenamaji būstą (2.4 pav.). $2009 \mathrm{~m}$. Lietuvos banko duomenimis, paskolas būstui ịsigyti yra paèmę 11,2 \% Lietuvos namų ūkių. Vidutinis paskolos grąžinimo terminas - 26 metai. Paèmusių paskolas būstui namų ūkių pajamos buvo beveik dvigubai didesnès už vidutini Lietuvos namų ūkių pajamų lygị. Jų šeimos mènesio pajamų vidurkis yra 4540 litų, o Lietuvoje šeimos pajamų vidurkis yra 2422 litų (Lietuvos bankas 2010).

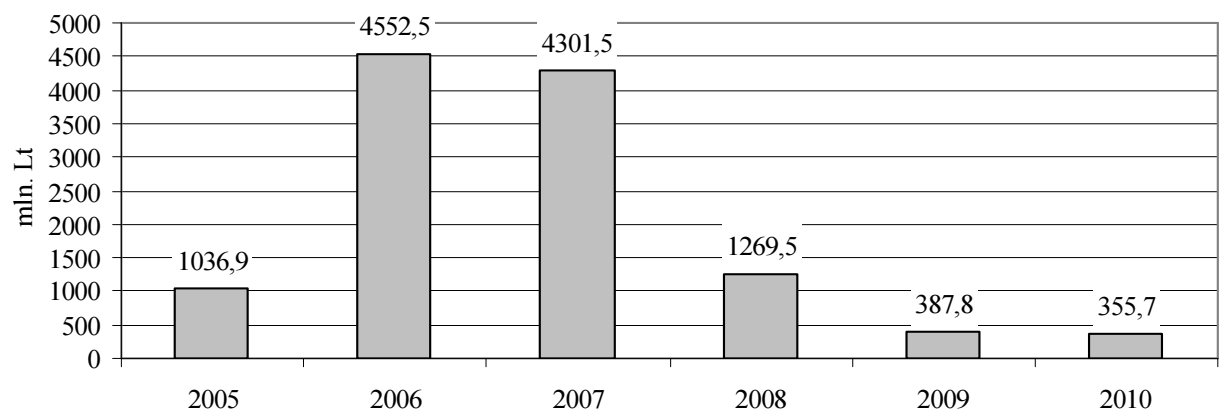

2.4 pav. Paskolos būstui ịsigyti

Fig. 2.4. Mortgage loans 
Toki norą skolintis lèmè tiek aktyvi reklama (gyvenimo skolon idejja buvo mažai būdinga pokomunistinèje visuomenejje), tiek žemos paskolų palūkanų normos (kurios sudaro brangiausią kredito dalị). 2005 m. rugpjūtị būsto paskolų palūkanos nukrito iki rekordiškai žemo lygmens - sudaré apie 3,5\% (2.5 pav. (Lietuvos bankas)). Šią tendenciją sustiprino palankios būsto kreditavimo sąlygos. Bankai pradèjo išduoti būsto paskolas iki $100 \%$ jų vertès, maksimali būsto kredito trukmè pasiekè net 40 metų. Prie būsto rinkos plètros prisidèjo tokios mokestinès lengvatos, kaip:

- gyventojų pajamų mokestis sumažintas nuo $33 \%$ iki $24 \%$;

- galimybé iš apmokestinamujų pajamų išskaityti palūkanas už būsto kredita.

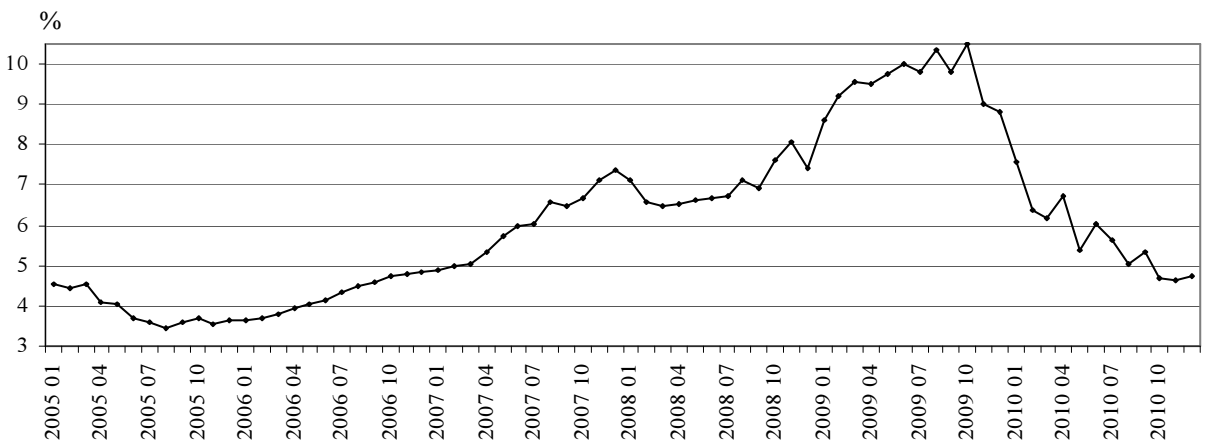

2.5 pav. Paskolų būstui ịsigyti palūkanų normos

Fig. 2.5. Interest rates on mortgage loans

Augimas itin jautèsi Vilniuje ir Klaipèdoje. Statybos įmonès, siekdamos kuo didesnio pelno, skubejjo kuo greičiau vykdyti tokias statybas, neskirdamos reikiamo dèmesio nei atliekamų darbų, nei naudojamų medžiagų kokybei.

Teisinè aplinka - tai politinè sistema, teisès aktai, nuosavybès teisès. Politinei ir teisinei aplinkai įtaką daro valstybinès ir visuomeninès įstaigos bei organizacijos, kitos interesu grupès. Dirbdama konkrečioje šalyje statybos imonè turi paisyti šalyje veikiančios politinès jègos, kuri formuoja valdžios ir valdymo struktūras (parlamentą, vyriausybę).

Verslas ypač priklausomas nuo veikiančios sistemos biurokratiškumo lygio. Tinkamas pavyzdys gali būti sudètinga statybos leidimų gavimo sistema.

Išsivysčiusiose šalyse verslą kontroliuojantys ịstatymai priimami:

- siekiant apsaugoti vienus verslininkus nuo kitu (pvz., smulkiuosius verslininkus nuo stambiujju). Antimonopolinès agentūros, konkurencijos priežiūros organizacijos, monopolijų ir susijungimų komisijos stengiasi užtikrinti, kad konkurencijos ịstatymai būtų vykdomi;

- bandant apsaugoti vartotojus nuo verslininkų neteisètų veiksmų. Jeigu niekas nekontroliuotų, kai kurie verslininkai imtųsi gaminti menkaverčius 
produktus, meluotų savo reklamose ir apgaudinètų vartotojus. Dalis šalių yra prièmusios griežtus įstatymus, ginančius vartotojų teises. Pavyzdžiui, Norvegijoje uždraustos kai kurios pardavimo skatinimo formos (konkursai, premijos) kaip netinkami ar neteisingi produktų rẻmimo būdai.

"Gallup International Association“ duomenimis (2007), statyba yra labiausiai korumpuota verslo sritis: pagal korupcijos lygi po viešuju darbų ir statybos sandorių eina ginklų ir gynybos bei naftos pramonè ir energetika.

Dèl viešai finansuojamų projektų Vidurio ir Rytų Europos statybos sektoriui iki 2008 m. vidurio buvo būdingas augimas. Ši šaka užèmè didesnę šalies BVP dali, lyginant su Vakaru Europos šalimis: Čekijos Respublikoje statybos sektorius siekia $15 \%$ šalies BVP, o Didžiosios Britanijos ekonomikoje ji sudaro tik $6,6 \%$. Čekų statybininkai gauna užsakymų sukurti būtinos infrastruktūros ir viešuju pastatų (ligoninių ir teismo rūmų). Augant pragyvenimo lygiui, auga ir gyventojų galimybės imti paskolas būstui i̇sigyti. Austrijos grupé „Strabag“ jau seniai issisąmonino Rytų augimą dè šių priežasčių. Trečdalis jos 9,43 mln. eurų metiniu pajamų yra iš šio regiono (Spink 2008). Hans Peter Haselsteiner sako: „Augantis BVP ir asmeninès pajamos turi teigiamą poveiki investicijoms i infrastruktūrą ir privačią statybos veiklą." Jis tikisi, kad nuolatinis pinigų srautas finansuojant projektus šalyse, kurios neseniai įstojo į ES, nenutruks per ateinančius penkerius metus.

Išsivysčiusiose šalyse siekiama tiesiogiai sumažinti valstybines išlaidas būstui. Siekiama mažinti netiesiogines subsidijas, ribojant lengvatinių kreditų rèmimą. Lietuvoje valstybinių lèšų būstui mažinimo priežastys ir tendencijos yra nulemtos nacionalinių makroekonominių ir socialinių pokyčių, tokių kaip privatizacija, decentralizacija, valstybès vaidmens mažèjimas, energijos išteklių brangimas.

Gamtiné aplinka - tai terpé, kurioje egzistuoja apstatyta ir humanizuota aplinka. Gamtinè aplinka veikia ir yra pati veikiama šios žmogaus perkuriamos sistemos. Gamtinè aplinka tiekia žaliavų ir išteklių visai statybos veiklai. Ji vertinama pirmiausia pagal gamtinių išteklių pobūdi, kiekị ir prieinamumą, o antroje eilèje - pagal klimatą, būdingą konkrečiai vietovei.

Lietuvos statybos medžiagų ir gaminių pramonè (neiskaitant energetikos pramonès) suvartoja daugiausia elektros ir kitų rūšių energijos. Dẻl pasenusių gamybos technologijų naudojimo Lietuvoje statybos medžiagoms ir gaminiams pagaminti reikia daugiau energijos negu ekvivalentiškiems Vakarų Europoje gaminamiems produktams. Pastaruoju metu vis daugiau užsienio statybinių medžiagų gamintojų ateina ị Lietuvos rinką su savo naujomis gamybos technologijomis.

Daugelio Vakarų Europos šaliu ir JAV vyriausybè tobulina įvairias priemones energijai pastatuose taupyti. Šios priemonès yra brangios ir negreitai atsiper- 
ka (pagyvenusiam žmogui gali visiškai neduoti ekonominio efekto). Todèl gyventojai dažnai yra mažiau suinteresuoti igyvendinti energijos taupymo pastatuose priemones negu valstybè. Skatinant taupyti energiją būtina valstybès parama. Apie 40 \% Lietuvos energijos išteklių iššvaistoma tiekiant energiją gyvenamiesiems ir visuomeniniams pastatams. Šiuo metu renovacija ir energijos taupymas yra vienos pagrindinių problemų išsivysčiusiose šalyse ir Lietuvoje.

Statybos industrija turi būti organizuojama taip, kad per visą statinio gyvavimo laikotarpi (t. y. nuo tikslų nustatymo ir projektavimo, statybos produktu gamybos (apimant ir perdirbamas medžiagas ir gaminius), statybos iki eksploatavimo, pastatų ūkio valdymo ir griovimo) būtų minimizuotas neigiamas poveikis aplinkai ir energijos sąnaudos. Mažai energijos vartojančios technologijos statyboje turi ne tik mažinti šiltnamio efektą sukeliančių i aplinką išmetamų teršalų kieki, bet ir bendrąsias statinio gyvavimo išlaidas (iddiegus saulès energiją vartojančias technologijas, galima tikètis pasiekti šiuos tikslus). Statybos atliekoms gabenti ir utilizuoti reikia papildomų išlaidų. Statinio gyvavimo proceso metu mažinant atliekų apimtis, sutaupoma valstybės ir statybos bendrovių lëšų.

ES kelia didelių aplinkosaugos reikalavimų pramonès šakų gamybos atliekoms (EU Directive 96/61/EC 2007). Aplinkosaugos politika verčia ieškoti, kaip kuo geriau naudoti gamybos atliekas. Dali statybinių atliekų (pvz., betono, skiedinio) galima perdirbti ir vèl panaudoti. Plytos ar metalas gali būti naudojami ir neperdirbti. Statyba yra pagrindinis biriujų medžiagų vartotojas ir pramonès šaka, kuri gali naudoti kitų pramonès šakų gamybos atliekas.

Technologiné aplinka. Imonès turi visą laiką analizuoti naujų technologijų atsiradimo galimybę ir kaip tai gali jas paveikti. Konkurencija taip pat priklausoma nuo to, kokia technologija vienoje ar kitoje ūkio šakoje yra prieinama. Būtent kūrybingas naujausių technologijų taikymas įmonèms užtikrina konkurencini pranašumą. Ir tai liečia ne vien tik informacinių technologijų naudojima, kuris pastaruoju metu susilaukè ypatingo dèmesio. Technologinis i̇monė pažangumas didina gamybos našumą.

Naujos technologijos atveria naujų rinkų ir naujų galimybių. Technologinè aplinka kinta labai greitai. Imonès, kurios nespejja žengti su technologiju kaita, būna priverstos palikti rinką. Trumpejja pats technologijos gyvavimo ciklas. Moksliniams tyrimams atlikti ir naujoms technologijoms kurti reikalingos didžiulès investicijos. Pavyzdžiui, naujam vaistui sukurti farmacijos bendrovès išleidžia apie 350-450 mln. eurų. Dèl naujų technologijų kūrimo ir diegimo brangumo daugelis imonių nerizikuoja investuoti i naujų technologijų tyrimus, o apsiriboja esamų savo produktų tobulinimu. Kitos i̇monès, vengdamos rizikos, susijusios su naujų technologijų kūrimu, tiesiog kopijuoja konkurentų produktus. Todèl dauguma naujų technologijų tyrimų užima veikiau ginamają nei puolamają poziciją.

Technologijoms sudètingejjant siaurèja specializacija. Dažnai ne tik imonès specializuojasi siauroje technologinejje srityje, bet ir pačioje imonejje tik dalis 
personalo gali atlikti vienas ar kitas operacijas. Tai, kad dingsta galimybė pasikeisti ar pavaduoti, brangina darbo jègą ir produkciją ar paslaugas.

Sprogus gyvenamosios statybos burbului, statybos šakoje jaučiamos labai neigiamos tendencijos, nes pakilimo laikotarpiu susikūrè daug naujų statybos firmų, kurios bet kokiais keliais siekia patekti i statybų sektorių, nors neturi nei reikiamos kvalifikacijos, nei darbo ir materialinių išteklių. Jos dalyvauja rangos darbų konkursuose atlikti tokius darbus, kuriems neturi reikiamų atestatų bei pajègumų. Dèl nepakankamos konkursų organizatorių kontrolès dažnai gyvenamujų namų rekonstrukciją vykdo statybos bendrové, kurios atestatas leidžia atlikti tik žemès kasimo ir vidaus apdailos darbus. Restauruoti bažnyčią veržiasi imonè, kuri iki šiol vykdè elektros perdavimo i̇monių statybą ir montažą.

Tiek pasaulio mokslininkai, tiek plačioji visuomenè vis dažniau svarsto, kad vien teisiniai ar politiniai ekonomikos bei verslo reguliavimo svertai yra nepakankami. Kyla būtinybė atsižvelgti į etinius, psichologinius, edukacinius verslo valdymo aspektus.

Sociokultūrine aplinka - tai institucijos, tradicijos ir kiti veiksniai, padedantys formuoti ir suvokti pagrindines visuomenès vertybes, pažiūras ir elgesio normas. Žmogaus asmenybè bręsta tam tikroje visuomeneje, kuri lemia pagrindines jo vertybes ir ỉsitikinimus. Susiformavusi žmogaus pasaulèžiūra vèliau veikia jo santykị su kitais žmonèmis (Kaklauskas et al. 1998). Kiekvienas individas ar socialinè grupé veikia tam tikroje kultūrinèje aplinkoje, kurią sudaro konkrečios tradicijos, papročiai ir jų besilaikantys žmonès. Svarbiausios tradicijos perduodamos iš kartos i kartą, o jas stiprina visuomeniniai institutai: istatymai, bažnyčia ir pan.

Darbinis bendravimas yra viena reikšmingesnių socialinès ir kultūrinès sąveikos rūšių. Darbo santykių lygmuo, darbuotojų karjeros galimybės, naujausių technologijų naudojimas padeda organizacijoms, dirbančioms statybos ir nekilnojamojo turto verslo srityje, geriau naudoti savo potencialą ir didinti gamybos efektyvuma.

Pokario metais Vokietija atsidūre katastrofiškoje padètyje: sugriauti miestai ir fabrikai, daugiau nei trijų milijonų darbingų vyrų, žuvusių kare, netektis, beveik 20 milijonų pabėgèliu ir ištremtujų. Svarbiausios ekonominio stebuklo Vakarų Vokietijoje priežastys buvo: JAV finansinè parama pagal vadinamaji „Maršalo planą" (iš visos 13 mlrd. dolerių paramos 1,7 mlrd. buvo skirta Vakarų Vokietijai, kuri vèliau $1 \mathrm{mlrd}$. doleriu grąžino), liberalios ir socialiai orientuotos rinkos ekonomikos sistemos ịvedimas, vokiečiu tuometinès kartos darbštumas, disciplinuotumas ir racionalumas, naryste Europos Sajungoje. Siekdamos rinkèjų palankumo, visos politinès partijos nèrèsi iš kailio, žadèdamos ne tik didinti atlyginimus, gerinti sveikatos apsaugą ir socialinį aprūpinima, mažinti mokesčius bei trumpinti darbo laiką. Skirtingai nei Lietuvos ir kai kurių kitų šalių politikai, vokiškasis pedantiškumas ir piliečių reiklumas vertè valdžios partijas lai- 
kytis prisiimtų i̇sipareigojimų, kurie dažnai viršijo ekonominę logiką. Nors ironiškai skamba, tačiau duotų pažadų nesilaikymas būtų ekonomikai naudingesnis. Šalies suvienijimas ekonominiu atžvilgiu reiške $16 \mathrm{mln}$. vartotojų vidaus rinkai laimejjimą. Suvienijimas pateisinamas politiniu, moraliniu bei socialiniu atžvilgiu. Tačiau biudžetui tai reiške didelę naštą. Vokietija pasiekè vieną brangiausių darbo valandų pasaulyje - 27,80 euro $(95,91 \mathrm{Lt})$. Lietuvoje analogiškas rodiklis yra vienas žemiausių visoje Europos Sajungoje - 5,09 euro (17,56 Lt). Brangią darbo valandą nulemia tai, kad Vokietijos darbdaviams prie išmokèto atlyginimo prisideda dar apie 92 proc. sąnaudų už atostogas, mokamas šventines dienas, ligos atvejus, privalomas socialines įmokas (Penkaitis 2008).

Demografinè aplinka. Demografiniai pokyčiai veikia darbo jègos pasiūlą, vartotojų sudèti. Reikšmingiausi šios aplinkos pokyčiai:

- spartus pasaulio gyventojų skaičiaus didejjimas, sukeltas didelio gimstamumo lygio ekonomiškai silpnose šalyse;

- gimstamumo mažejjimas ir gyventojų senèjimas išsivysčiusiose šalyse;

- pokyčiai šeimos struktūroje ir ne šeimos pobūdžio namų ūkio plitimas (santuokinius ryšius vis plačiau keičia partnerystè);

- migracija;

- išsilavinimo lygio kilimas ir tarnautojų skaičiaus didejjimas;

- etniniai gyventojų struktūros pokyčiai.

Nagrinejjant tvariają statybos raidą (Black 2004) skiriamos trys lygiavertès ir glaudžiai susietos jos sudedamosios dalys: ekologinè dimensija, ekonominis aspektas bei socialine dimensija. Nuo pastarosios tvarumo priklauso, kokiu mastu ateičiai bus išsaugotos socialinès vertybès, socialinis tapatumas, socialiniai santykiai ir socialinès institucijos. Ši socialinį aspektą iliustruoja:

- plačiai pripažistamos ir ilgalaikès normos ar vertybès, pavyzdžiui, abipusis bendravimas, procesinis teisingumas ir teisiu gerbimas;

- asmens tapatumo ir kultūrinès įvairovès tausojimas (tai būtų socialinis biologinès îvairovès atitikmuo);

- socialinių instituciju gebejjimas tenkinti žmonių poreikius;

- socialinių i̊staigu gebejjimas reaguoti i netikètus pokyčius, pavyzdžiui, aplinkos sąlygų, ekonomikos ar technologinius pokyčius.

Nors dažnai teigiama, kad įmonès socialinès atsakomybės koncepcija yra stambiujų imonių varomoji jèga (Bernatonytè et al. 2009), socialinès atsakomybès praktika egzistuoja ir smulkiojo bei vidutinio verslo praktikoje. Nuolat didèjantis investuotojų ir verslo lyderiu paramos smulkiujų verslo įmonių iniciatyvų skaičius signalizuoja apie savotišką smulkiojo bei vidutinio verslo vaidmens tvariojo vystymosi procesuose pripažinimą. Labiausiai ekonominè krizė sukelia nekvalifikuotų darbininkų darbo vietų išsaugojimo problema, nes smulkusis verslas pirmiausia privalès rūpintis išlikimu. Tai leidžia daryti apibendrinamają 
išvada, kad ekonominè krizė i̇monès socialinès atsakomybės diegimą Lietuvos smulkiojo verslo įmonèse paveiks neigiamai.

Kultūra - tai žmogaus visuomeniškumo apraiška. Ji apima tikejjimo, moralès, teisès, papročių esmę, kuri nusistovi kaip savaime suprantama ir natūrali perteikiant iš kartos i kartą esmines sąvokas kas yra gerai ar blogai. Visai ekonomikai globalizuojantis, statybos ir nekilnojamojo turto verslas besiplèsdamas apima ịvairių kultūrų aljansus. Bandant primesti svetimas kultūrines nuostatas versle, galima sulaukti neigiamos reakcijos - ir atviros (atsisakymas laikytis tam tikros tvarkos), ir užslèptos (našumo sumažèjimas). Todèl kultūriniai aspektai būtinai tampa aktualūs kai bendruose projektuose susiduria skirtingų tautybių bei kultūrinių sampratų atstovai. Igyvendinant sudètingą tarptautini statybos projekta, svarbios profesinès dalyvių žinios bei gebejjimai. Tačiau tampa aktualu, kad jie būtų jautrūs ir lankstūs kultūriniams skirtumams, kurie gali prieštarauti jų vidinėms nuostatoms (Fellows, Liu 2008). Kilus nenumatytų sunkumų ar būtinybei daryti projekto pakeitimus, dalyviai turi būti pasirengę ne tik informuoti partnerius apie savo sprendimus, bet ir iš bendradarbiavimo perspektyvos dinamiškai juos koreguoti.

Bet kuri imone, nusprendusi investuoti kitoje šalyje, turi įvertinti sociokultūrinius skirtumus ir nepadaryti klaidų panašių i tas, kuria Bulgarijoje 1990aisiais padare „Roverio“ kompanija. Imonès vadybininkai neskyrè pakankamai dèmesio tam, kad Bulgarijos visuomenès ir valdininkų sąmonèje gilų pédsaką paliko keli komunistinès ideologijos dešimtmečiai (Elenkov, Fileva 2006).

Krizès metu organizacinè imonès kultūra veikia įmonès efektyvumą. Organizacinès kultūros vertybès daro ittaką korporacijoje naudojamiems etiniams standartams ir vadovų elgsenai (Montana, Charnov 2008). Nauji ị organizaciją atvykę darbuotojai gali paveikti organizacinę kultūra. Pavyzdžiui, i darbo kolektyvą i̇siliejęs naujas projektų vadovas (turintis specifinių žinių ir elgsenos bruožu, būtinų su krize susijusioms statybos problemoms spręsti) gali paveikti bendrą organizacijos kultūrą.

Geografine aplinka. Geografinès sąlygos veikia verslo vystymo kryptis: ežeringas, gražus gamtovaizdis gali suformuoti norą statyti gyvenamuosius namus, tačiau atokumas nuo pagrindinių kelių ir didžiujų miestų taptų rimta kliūtimi. Geras geografinis išsidestymas ir patogios komunikacijos gali būti pageidautini pramonès ar logistikos imonès statybai, bet prastas gruntas arba potvynių grèsmé gali vèlgi paneigti projekto igyvendinimo galimybes.

Rinkos, kurioje užsiimama statybos verslu, sąlygos diktuoja pasirinkimo galimybes. Pavyzdžiui, jeigu mokesčių lygis yra gana aukštas, tai nacionalinès firmos dèl didelès mokesčių naštos gali arba bankrutuoti, arba sumažinti savo efektyvumą (padidejjus mokesčiams, sumažès tarptautinių kompanijų, norinčių ieiti i vietinę rinką, konkurencija). Ir priešingai, sumažinus mokesčius, tarptautinès kompanijos, įeidamos i vietinę rinka, gali arba išstumti nacionalines firmas 
iš jų rinkos dalies, arba nacionalinès firmos, susidūrusios su tokia konkurencija, bus priverstos padidinti savo efektyvumą. Vykstant šiam procesui pasekmès gali būti jaučiamos įvairiose srityse (nedarbas, mokesčių surinkimo lygio svyravimas ir pan.).

Pokomunistiniame Vidurio Europos regione planuodami sveikatingumo kompleksą (Tijhuis 2008) tarptautinio projekto dalyviai susidūrè su įvairiomis problemomis. Šis regionas buvo intensyviai pletojamas 2000-2005 m., prieš jo prièmimą i Europos Sajungą. Dèl gamtos grožio ir terminių šaltinių vieta atrodė labai tinkama tokiai veiklai vystyti. Tačiau dèl valstybinès nuosavybès vyravimo jau pirmuose projekto etapuose buvo susidurta su dideliais finansavimo sunkumais. Vèliau tarp projektuotojų ir klientų kilo konfliktas dèl galutinio produkto suvokimo, dèl skirtingo kultūrinio požiūrio, o tai lèmè, kad projektas nebuvo igyvendintas.

\subsubsection{Mezoveiksniai, darantys itaką statybai}

Etinius ir moralinius globalinès ekonominès krizès vertinimo aspektus $2008 \mathrm{~m}$. lapkriti Niujorke vykusioje JT Generalinès Asamblejos sesijoje aptare arkivyskupas Č. Miljore (Buika 2008). Kai nèra tvirtos atskaitomybès taisyklių ir reikiamo skaidrumo, neišvengiamas piktnaudžiavimas bei aplaidumas. Dažnai ịvairiose verslo srityse veikiantys asmenys užmiršta pamatines verslo etikos nuostatas. İ eilinio kliento kreditavimą ar nemokumą žiūrima labai griežtai ir imamasi sankcijų o finansų ,rykliams“ neretai daromos didelès nuolaidos, jiems pataikaujama nekreipiant demesio i pažeidimus. Nevienodą požiūrị atspindi ir tarpvalstybiniai finansų santykiai: Tarptautinès valiutos fondas kelia griežtas sąlygas neturtingu šalių paskoloms, o ị didžiųu industrinių valstybių finansinị ir biudžetini piktnaudžiavimą paprastai nereaguojama. Tokia padètis reikalauja didesnio globalinio solidarumo ieškant išeities iš finansinès krizès. Pagalba ir faktinès skriaudos atitaisymas (besivystančių šalių atžvilgiu) neturi apsiriboti tik formaliais užuojautos pareiškimais, bet ir konkrečiu dalies atsakomybès prisièmimu. Dabartinès finansų krizės akivaizdoje yra svarbi atsakomybè tụ, kurie dirba bankininkystès sektoriuje. Skolinimas yra tradicinè ir būtina socialinès veiklos dalis, tačiau finansų institucijos ir jų atstovai turi stengtis užtikrinti, kad skolinimas ir kreditų išdavimas atliktų savo privalomą funkciją - susietų santaupas su verslo vystymu, su gamyba. Bet kai skolinimas tampa prekyba finansiniais ištekliais, ju perpardavinejjimu siekiant gryno pelno be pateisinamo naudojimo, tokia veikla jau negali padidinti visuomenès gerovès. Finansų institucijų veikèjai ir skolintojai tampa faktiškosios vagystès bendrininkais.

Nors kokybès sąvoka pradèta giliau tyrinèti nelabai seniai, šio tyrimo autoriai įsitikinę, kad vis delto yra ryšys tarp požiūrio į kokybę ir korporacijų žlugimo, nors iš šio konkretaus tyrimo ryšys sunkiai matomas. Kokybès nepaisymas 
neišvengiamai sukelia korporacijos žlugimą. Kokybės problemos/nesėkmès negali būti ignoruojamos be galo, anksčiau ar vèliau nesprogdamos ir nesukeldamos organizacijai baisių pasekmių. Be abejonès skirtingai nuo žmogaus mirties, korporacijos baigtis yra išvengiama. Idiegus tinkamą kokybès valdymo sistemą, galima efektyviai užčiuopti visus gresiančio bankroto simptomus ir pagrindines priežastis (Marwa, Zairi 2008).

Didelè dalis rekonstrukcijos darbų atliekama naudojant ịvairių fondų lešas. Jei rangos konkursus laimi tos firmos, kuriu pasiūlyta kaina siekia vos $50 \%$ projekto ekonominèje dalyje apskaičiuotos kainos, aišku, kad atlikti rekonstrukcijos darbai tiek savo apimtimi, tiek kokybe visiškai neatitiks projektavimo dokumentuose keltų reikalavimų. Patikrinus, kaip naudotos rekonstrukcijai skirtos lěšos, daugelis darbų bus pripažinti nekokybiškais. Analizuojant tokias nerealiai mažas konkursų pasiūlymų kainas, paaiškèja, kad:

- nerealiai mažą kainą siūlo statybos įmonès, kurios yra ant bankroto ribos. Joms svarbu išsilaikyti dar kelis mènesius, susirinkti tam tikrą dalị pinigų, vèliau, neužbaigus darbų, bankrutuoti;

- dalis statybos imonių dalyvauja visuose Lietuvoje skelbiamuose rangos darbų konkursuose, kuriuos laimi, nes siūlo labai mažą kainą. Tačiau tokia ¿monė neturi nei reikiamo darbuotojų skaičiaus, nei kitokių galimybių vystyti veiklą visoje Lietuvoje. Tokia imonè perduoda darbus subrangovams, kuriems vèliau neapmoka už dalį atliktų darbų. Taip nukenčia visiškai nekaltos, dorai norejusios dirbti imonès, kurioms dèl tokių nesąžiningų veiksmų kyla bankroto grèsmé;

- atsiranda dar viena rangos konkursų dalyvių grupé, kuri, labai maža kaina laimèjusi pasiūlymą, darbus už tam tikrą kainą siūlo perleisti kitoms įmonèms;

- pastebima tendencija parengti konkurso sąlygas kokiai nors konkrečiai imonei. Pavyzdžiui, konkursų sąlygose nurodyta dalyviams pateikti Profesinés sveikatos ir saugos vadybos sistemos OHSAS 18001 ir Socialinio atsakingumo SA 8000 standartus, nors pastaraji Lietuvoje turi tik dvi statybos įmonès. Todèl aišku, kam iš dalyvių pritaikyti konkretūs reikalavimai.

Gilejjant bendrai ekonomikos krizei statybos verslas tampa mažiau moralus. Vienas iš pavyzdžių - tyčinis bankrotas. Yra įmonių, kurios teisindamosi dèl krizès patiriamais dideliais sunkumais viešai pareiškia negalinčios atsiskaityti su bankais, subrangovais, tiekejjais. Tačiau pačios tuo pat metu didžiają dali turimų lěšų perveda į naujai sukurtą imonę. Tai nèra vien tiktai Lietuvos problema. Visoje Europoje kovojama ir su vadinamuoju Fenikso sindromu. Pavyzdžiui, Airijos mokesčiu administratoriai pastebejo, kad per pastaruosius šešerius metus septynis kartus padaugèjo atvejų, kai sukaupę didelį skolų bagažą verslininkai tęsia veiklą pervadinę savo imones. Irodyti pavyksta tik ketvirtadali šių atvejų (Phoenix syndrome 2009). 
Vis dažniau bandoma vertinti valstybių šešèlinius aspektus: šešèlinę ekonomiką, šešèlinę vyriausybę ir pan. Pastaruoju metu dalis pasaulio politikų pripažista, kad didelès korporacijos ir bankai valstybèse vis dažniau imasi šešèlinès vyriausybès vaidmens. Tai pastebima bankų sektoriuje. Tiek Vokietija, tiek Prancūzija siekia reguliuoti bankų sektorių. Didelès korporacijos siekia finansuoti pagrindines politines partijas, kurios, patekusios i valdžia, stengiasi priimti istatymus, palankius rèmejjams. Ekonomistai yra ịrodę tiesiogini ryši tarp mokesčiu didinimo ir šešèlinès ekonomikos augimo. Ne išimtis ir Lietuva: 2009 m. pradžioje pakèlus mokesčius, išaugo ir šešèlinè ekonomika.

Prastejjanti ekonominè situacija ir mokesčių naštos kèlimas padidins šešèlinès ekonomikos mastus. Dalyvavusieji tyrime mano, kad 2008 m. šešèlinès ekonomikos dalis nuo BVP išliko beveik tokia pati kaip ir prieš tai buvusiais metais ir siekè $18 \%$. $2009 \mathrm{~m}$. buvo prognozuojamas didelis šešèlinès ekonomikos padidejimas. Tyrimo duomenimis, šešèlinè ekonomika turejo išaugti $5 \%$ punktais ir siekti 22,7 \% BVP. Taigi kone kas ketvirtas litas - šešèlyje. Didesnis šešèlis Lietuvos ekonomikos tyrime paskutini karta prognozuotas tik 1998 m. Paklausti, kiek ekonomine veikla užsiimančių ūkio vienetų bent dalị savo veiklos vykdè ir vykdys šešèlyje, tyrimo dalyviai teigè, kad $2008 \mathrm{~m}$. šešèline veikla užsièmé $28 \%$ ūkinių subjektų, o 2009 - net $40 \%$. Šešèlis - vokeliai, pajamų nuslèpimas, nelegali gamyba ar paslaugu teikimas, kita veikla bandant nuslëpti mokesčius (Lietuvos laisvosios rinkos institutas 2009).

Verslo pasaulyje informacija turi savo vertę ir neretai tampa paklausia preke. Dèl to tarp verslininkų iprasta konfidencialumo isipareigojima numatyti kiekvienoje sudaromoje sutartyje (Pilipaite 2009):

- dažnai konfidencialumas sutarties šalims nèra esminė sąlyga, be kurios sutartis apskritai nebūtų sudaryta;

- praktiškai konfidencialumo įsipareigojimas paprastai suformuluojamas lakoniškai, bet ganètinai griežtai nurodant, kad sutarties sudarymo turinys ir (arba) sutarties sudarymo faktas negali būti atskleistas tretiesiems, t. y. sutarties šalimis nesantiems, asmenims;

- konfidencialumo issipareigojimo nenumatyti sutartyje (jei jis nenumatytas istatymuose) tam tikrais atvejais gali būti net labai naudingas, ypač kai daugiau negu du verslininkus sieja sutarčiu grandinè, pavyzdžiui, statybos rangovui naudinga oficialiai supažindinti subrangovus su rangos sutarties, sudarytos tarp rangovo ir užsakovo, turiniu. Tokiu atveju subrangovai, aiškiai žinodami pirminejje rangos sutartyje numatytų netesybų (delspinigių, baudų) dydi, siekdami sumažinti savo atsakomybę rangovui už subrangos sutarties terminų ar kitų sąlygų pažeidimus, negalètų gintis galimų rangovo nuostolių nenumatymu;

- istatymuose gali būti numatyti privalomi informacijos atskleidimo atvejai tačiau verslininkai gali issipareigoti privalomais informacijos atskleidimo 
atvejais neatskleisti informacijos daugiau negu yra privaloma ir (arba) apie informacijos atskleidimą nedelsiant informuoti kitą sutarties šali;

- tais atvejais, kai konfidencialumas yra esmine šalių derybu pradžios, sutarties sudarymo arba bendradarbiavimo apskritai sąlyga, patogu sudaryti atskirą teisiškai ịpareigojantị susitarimą dẻl konfidencialumo;

- siekiant konfidencialumo efektyvumo būtina užtikrinti atitinkamų isipareigojimų laikymąsi.

\subsubsection{Mikroveiksniai, darantys itaką statybai}

Pati artimiausia statybos įmonei aplinka apibūdinama kaip mikroaplinka. Šios aplinkos veiksnių pokytis greičiausiai pajuntamas, bet ir labiau valdomas.

Mikroaplinkai priskiriami elementai daugiausia tiesiogiai susieti su pačiu užsakovu, projektą vykdančia i̇mone, naudotojais. Reikia pabrèžti, kad mikrolygmens veiksniai priklauso nuo makrolygmens veiksnių. Pavyzdžiui, visą veikla, susijusią su pastato gyvavimo procesu, reglamentuoja ịvairūs įstatymai, norminiai dokumentai, kurie yra priimami makrolygmeniu.

Kol paklausa viršija pasiūlą, pardavejjas kels kainą tiek, kiek pirkejjai išgalès mokèti. Paklausą lemia tiek ekonominè (pinigu kiekis pas galimą pirkejja), tiek psichologinè sudedamosios dalys. Dažnai psichologinis aspektas gali stipriau paveikti paklausą. Psichologinę vertę sudaro dvi dalys: daikto naudingumas tenkinant pirkejjo poreikius ir pirkejjo ateities lūkesčiai. Siekis išsiskirti iš kitų ir igyti prestižą verčia žmogų ieškoti ne bet kokio būsto, o būtinai didžiulio namo. Kita vertus, jei aš manau, kad ateityje savo poreikiams tenkinti reikalingus daiktus bus sunkiau ỉsigyti nei šiuo momentu, psichologinè jų verte smarkiai išauga ir labai padidina kaina, kurią žmogus yra pasiryžęs sumokèti. Jei tokius lūkesčius pavyksta suformuoti dideliam skaičiui žmonių, galima dirbtinai sukurti paklausa, viršijančią ekonominę paklausą. Šie psichologiniai veiksniai labai paveikè ekonomikos pūtimąsi (Legkauskas 2009).

Nekilnojamojo turto pirkimo bumą daugiausia lèmè pervertintos pirkèjų kredito išsimokejjimo galimybės bei pasidavimas visuotiniam gyvenimo sąlygų gerinimui. Dažnai būstas buvo keičiamas pasiduodant aplinkinių itakai, norui pasirodyti ne blogesniems už kaimynus. Panašūs psichologiniai aspektai neleidžia krizès metu atsigauti normaliems rinkos santykiams. Apsisprendęs pirkti būsta gyventojas persigalvoja vien pasklidus kalboms apie galimas jo darbovietès reorganizacijas ar net žinioms apie ekonomikos rodiklių pablogejjimą kaimyninejje valstybejje. Bijantis dèl savo ateities, atsisakoma planuotų investicijų.

Bene pagrindinè paskolų ekonomikos yda ta, kad ilgainiui paskolų ekonomika nutrina ribą tarp darbo ir verslo ir eilinius žmones pradeda versti verslininkais. Riziką verslininkas prisiima todèl, kad turi specialiujų ekonomikos, vadybos, finansų ir kitų žinių, kurios leidžia jam riziką suvaldyti. Neturinčiam būtinų 
specialių žinių eiliniam investuotojui paskolų ekonomikoje nelieka nieko kita, kaip tik dalyvauti piramideje. Piramidès formavimasis prasideda tuo metu, kai investuotojai pradeda investuoti todèl, jog toje srityje investuoja ir uždirba kiti. Tokia piramide yra išskirtinai psichologinis fenomenas. Kuo daugiau žmonių tai daro ir uždirba, tuo daugiau kitų žmonių i ją ịsitraukia. Pabaiga visuomet vienoda: pirmieji, patekę i piramidę ir iš jos laiku išèję, gerai uždirba, o pagrindinè masè investuotoju praranda pinigus. Piramide - psichologinis, o ne kriminalinis fenomenas (Legkauskas 2009).

Emocijos ne tik daugiausia lèmé Amerikos kelią i dabartinę ekonominę krizę, bet taip pat gali užlaikyti ją ten. Pastaruoju metu įvardinus „Pasitikejjimo krizę: nuosmukio ir baimès ekonomiką", i̇vairių sričių mokslininkai pripažista lemiamą psichologijos itaką šiandienei ekonomikai (Knowledge@Wharton 2009).

Dirbančiam žmogui ir i̇monei, kurioje jis dirba, svarbus emocinis aspektas. Prie teigiamų emocijų priskiriami: malonumo pojūtis, susižavejjimas, džiugesys, išdidumas, pasitikejjimas savimi, pagarba, rami sąžinè, saugumas ir panašiai. Neigiamomis emocijomis laikomi: liūdesys, nuobodulys, baimé, nusivylimas, nerimas, nuoskauda, pavydas ir kita. Jei profesinejje veikloje lydi sèkmé, emocijos virsta euforija (padideja aktyvumas, kalbumas), užvaldo teigiamos emocijos. Ir priešingai, ištikus nesèkmei, atsiranda neužtikrintumas, baimè, nerimas. Tiriant galimo nerimo priežastis (Dobryninas, Gaidys 2004) išryškèja tendencija nerimauti dèl grèsmès prarasti darbą (stiprų nerimą jaučia $28 \%$ darbuotojų) ar nebeužtekti pakankamai pajamų pragyvenimui (stipriai nerimauja 34 \% gyventojų, o tai vèlgi siejasi su darbiniais santykiais). Šias grèsmes žmonès akcentuoja labiau nei baimes dèl santykių pablogejjimo šeimoje (tik $4 \%$ ) ar grèsmes tapti nusikaltimo auka (11\%).

2003-2008 m. Lietuvoje ypač suaktyvejjo bankų paskolų išdavimas. Jas labai lengvai gaudavo tiek statybos firmos, užsimojusios statyti daugiabučius ar vieno-dviejų butu gyvenamuosius namus, tiek gyventojai, panorę issigyti nuosavą gyvenamaji būstą. Tai itin jautėsi Vilniuje ir Klaipedoje. Statybos įmonès, siekdamos kuo didesnių pelnu̧, skubejjo kuo greičiau vykdyti tokias statybas, nekreipdamos reikiamo dèmesio nei atliekamų darbų kokybei, nei naudojamoms medžiagoms. Pagrindinis tikslas - kuo greičiau ir brangiau bei kuo mažesnèmis sąnaudomis parduoti savo pagamintą produkciją. Statybų piginimas vyko naudojant prastesnès kokybès, todèl pigesnes medžiagas, nesilaikant visų būtinų technologinių procesų reikalavimų. Tik darbo užmokesčiui lèšų buvo negailèta. Tokiems statybų mastams Lietuvoje èmé stigti kvalifikuotos darbo jègos. Buvo pasitelkti darbininkai iš kitų šalių bei viliojant į Vilnių ir Klaipedą darbininkus iš visos Lietuvos, mokant keleriopai didesnius atlyginimus nei priklausytu pagal atliktą darba. Vilniuje kranininkams, mūrininkams, kitų paklausių profesijų darbininkams buvo mokama po 10 tūkst. Lt ir didesnius mènesio atlyginimus. Tai 
kelis kartus viršijo tiek sąmatinius ịkainius, tiek kitų profesijų atstovų gaunamus atlyginimus. Supratę, kad Vilniaus ir kitų didžiujų miestų statybose visada susiras darbo, kai kurie darbininkai darbdaviams kèlè nepagristus reikalavimus, nesilaikė darbo drausmès. Tokiam nepagrisstam darbininkų reikalavimų augimui turejo ir mokesčių administratoriaus veiksmai. Iš statybos imonių vadovų buvo reikalaujama, kad darbininkams būtų mokamas ne mažesnis nei vidutinis visoje Lietuvoje atitinkamos šakos atlyginimas. I jokius paaiškinimus, kad tokị nerealų atlyginimų šuoli sukèlè staigus gyvenamosios statybos augimas, ypač Vilniuje ir Klaipėdoje, kad tai visiškai neatitinka pagrịstų normų darbininkų darbo našumo, atliekamų darbų kokybès, mokesčių surinkimą kontroliuojančios institucijos visiškai nekreipe dèmesio. Statybos vadovui liko du keliai - pasiduoti reikalavimui nepagristai kelti atlyginimus ir stebèti, kaip mažejja darbo našumas, arba būti nuolatos tikrinamam ir kviečiamam i pokalbius. Daugelis pasirinko pirmaji varianta, todèl taip smarkiai buvo išbalansuota visa statybos šaka. Tik sulèteję gyvenamosios statybos mastai statybos šakai leis sugrį̌żi i normalias vèžes, kai atliekamų darbų kokybei, darbuotojų sąžiningumui, darbo našumui skiriama reikiamai dèmesio.

Atlikus i̇vairių Artimujų Rytų imonių vadovų apklausą (Blackman 2009), paaiškejjo, kad tik $20 \%$ apklaustujų mano, jog regiono darbuotojų kvalifikacija yra pakankamo lygio. Buvo apklausta daugiau nei 600 vadovų, tarp jų 75 iš statybos ir nekilnojamojo turto sektoriaus. Edukaciniai aspektai apklausos dalyvių buvo išskirti kaip viena iš priemonių įveikiant nuosmukio sunkumus. Tinkamas profesinis ir inžinerinis darbuotojų (ypač jaunų) parengimas stipriai pakelia darbo našumą.

Vokietijos statybos pramonė visada išsiskyrè aukšta darbuotojų kvalifikacija ir darbų kokybe (Bosch 2007). Tiek imonių, dirbančių Vokietijos teritorijoje, tiek už jos ribų darbų kokybès krizę lèmé pigesnès darbo jègos iš kitų šalių samdymas. Statybos šakos vystymo koncepcijoje numatoma būtinybė skirti pakankamą dèmesį visų lygių darbuotojų (architektų, inžinierių, sekretorių, brigadininku̧, darbininkų) nenutrūkstamam mokymui ir karjerai visą gyvenimą. Užtikrinant galimybę mokytis ir garantuojant užimtumą, norima išlaikyti specialistus būtent statybos sektoriuje.

Konkurentai - tai rinkos dalyviai, kurie siūlo galimiems vartotojams tuos pačius ar panašius produktus. Statybos sektoriuje įmonès siūlo įvairiausios paskirties statinius: komercinius, gyvenamuosius, skirtus viešiesiems reikalams. Konkurentų itakos negalima ignoruoti. Konkurentai varžosi rinkoje, pasitelkdami įvairiausias priemones, dažniausiai taikomas ịvairus kainos ir kokybės santykis. Neatsilaikiusi konkurencinèje kovoje imonè bankrutuoja, todèl svarbu užsitarnauti visuomenès pasitikejjimą. Statinius norès įsigyti ir jais naudotis tik tada, kai juos pastačius, pardavusi ar išnuomojusi ̨̨monè bus pranašesnè už kitas, tokios pat paskirties statinius statančias, parduodančias ar nuomojančias imones. 
Pranašumas gali būti: mažesnè kaina, kokybiškesnès medžiagos, suteikiamos papildomos paslaugos, mandagesnis aptarnavimas, rekomendacijos ir pan.

Kreditoriais statybų rinkoje dažniausiai tampa bankai ar kitos kredito imonès, suteikiančios statybos verslui paskolas su atitinkamomis palūkanomis ir sąlygomis. Ne kiekviena įmoné gali tokią paskolą gauti. Reikalingas pakankamas turtas, kuriuo būtų užtikrinti imamas paskolos grąžinimą. İmonè turi turèti pasitikejjimą - kreditoriai vengia tokių, kurios atsiduria vienų ar kitu partnerių juoduosiuose skolininkų sąrašuose. Statinio statytojai, pasirinkdami ịstaiga paskolai gauti, turi būti užtikrinti finansiniu tos ịstaigos stabilumu, nes jų nesèkmès tiesiogiai paveiktų statinio statybą arba vystomo projekto baigti.

Galimybe rinktis subrangovus leidžia optimizuoti visą statybos ar statinių priežiūros procesą. Imonei dažnai per brangu turèti visų sričių specialistus ir irangą (darbams, kurie vykdomi tik trumpa laikotarpi lyginant su viso projekto igyvendinimo trukme, pavyzdžiui, žemès darbai). Todèl geriau samdyti specializuotas imones.

Sèkmingas tiekëju pasirikimas - tai ne tik tinkamo projekto igyvendinimo prielaida, bet ir tam tikra rizika. Norint užtikrinti sklandų darba, tiekejjai turi aprūpinti medžiagomis, žaliavomis, iranga ir kitais reikalingais statybos ištekliais laiku ir reikiamais kiekiais, nes dèl sustojusios statybos projektas vèluoja ir atsiranda nuostoliu.

Statybos medžiagų ir gaminių aprūpinimo proceso efektyvumo didinimas naudojant internetines technologijas. Galimybè užsakyti statybines medžiagas bei gaminius ir koreguoti užsakymų terminus bei apimtis internetu sutaupo statytojui daug laiko ir išteklių.

Tarpininkai reikalingi, kai statinys statomas savo lèšomis. Būtent tarpininkai ieško būsimų statinio naudotojų. Pardavus ar išnuomojus pastatytus statinius grižta investicijos.

Dèl aukšto vietovès infrastruktūros išvystymo lygio sumažeja bendra statybos darbų savikaina ir kartu statinio kaip galutinio produkto patrauklumas vartotojams. Lietuvos Respublikos Vyriausybè, peržiūrèjusi nekilnojamojo turto verčių skaičiavimo tvarka, ivvertino daugiau rinkos veiksnių ir skyrė daugiau dèmesio inžinerinei infrastruktūrai. Ši tvarka patvirtinta Lietuvos Respublikos Vyriausybės 19990224 nutarimu Nr. 205. NT mokesti šiuo metu moka juridiniai asmenys ir gyventojai, kurie savo turtą naudoja komercinei veiklai. Mokesčio dydi (nuo 0,3 iki $1 \%$ turto vertès) nustato savivaldybès.

Informacinès sistemos diegiamos visuose statybos valdymo etapuose. Elektroninès valdžios portaluose sudaromos galimybès: pateikti prašymą gauti projektavimo sąlygų sąvadą, statybos leidimą ar leidimą tęsti sustabdytą statybą: užpildyti prašymą gauti statinio pripažinimo tinkamu naudoti aktą ir pateikti prašymą gauti pažymą apie nebaigtas statybas; pratęsti statybos leidimą ar perrašyti ji kito vardu; pateikti pranešimą apie galimas savavališkas statybas kartu su 
jų nuotraukomis; užregistravus prašymus peržiūrèti jų būsenas; sužinoti, kokius dokumentus reikia pateikti su prašymu (Infostatyba 2009). Tiesa, bandant pasižiūrèti elektroniniu būdu projektavimo sąlygas teikiančių institucijų sąrašą jis pasirodè besąs tuščias.

Iprasta manyti, kad pastato gyvavimo proceso kompiuterinio projektavimo technologijos padeda automatizuoti ir paspartinti ne tik brèžinių sukūrimą, bet ir lydimujų dokumentų generavima, gaminio ruošimą gaminti ir montuoti. Tačiau šiandien brěžiniams braižyti ir kitokiems projektavimo dokumentams rengti dažnai naudojamos bendrosios paskirties grafinès sistemos (CAD) ir visiškai mažai inžineriniams skaičiavimams naudojama konstrukcijų skaičiavimo ir analizès sistema (CAE). Esant tokiai technologijai kiekvienas brěžinys saugomas atskiroje byloje, o vieninteliu informacijos generavimo ir kontrolès šaltiniu lieka žmogus, kuris iš pradžių kuria atskirus brèžinius, paskui juos koreguoja ir atnaujina, seka ir taiso klaidas. Be jokios abejonès, tokia projektavimo dokumentų sukūrimo technologija turi savo privalumų, tačiau neišsprendžia nei standartinės projektavimo dokumentų rinkinio sukūrimo problemos, nei suderinto tarp visų projektavimo proceso dalyvių informacijos atnaujinimo visose projektavimo proceso stadijose (Popov, Grigorjeva 2010).

\subsubsection{Suinteresuotos grupès}

Investuotojai - tai dalyviai, kurie savo lèšas investavo į konkretaus statinio statybą ar projekto igyvendinima, tikèdamiesi, kad jų investicijos atsipirks. Tik gera reputacija, rekomendacijos ir konkretūs jau sẻkmingai ịvykdyti projektai gali sèkmingai pritraukti potencialius investuotojus. Šie savo ruožtu prižiūri visą statinio statybos ar projekto igyvendinimo eigą ir turi teisę priimti ar atšaukti sprendimus, siūlyti pakeitimus. Nuo jų pasitikejjimo priklauso projekto efektyvumas ir sklandumas.

Darbuotojai - tai vienas svarbiausių veiksnių, darančių itaką statybos verslui. Tinkamas darbuotojų parinkimas sudaro daugiau nei pusę realiu galimybių sẻkmingai užbaigti statinio statybą ar nekilnojamojo turto sandori. Tinkami darbuotojai - tai asmenys, turintys reikiamą išsilavinima, kvalifikaciją bei patirti. Jie yra atsidavę, ištikimi savo darbui, lojalūs įmonei, naudoja visas turimas žinias Vadovas turi būti užtikrintas, kad darbuotojai laiku, są̌̌iningai ir tinkamai atliks jiems pavestus darbus, nekels streikų, nepiktnaudžiaus savo padètimi. Darbdavys turi pelnyti darbuotojų pasitikejjima, sukurti tinkamą darbo aplinką. Kolektyvas, kuriame tvyro šilti, draugiški santykiai ir pasitikejimas, dirba našiau, o tai užtikrina sklandžią statinio statybos ar projekto igyvendinimo eigą ir nuostolių išvengimą.

Pagrindinis tikslas - kuo brangiau ir kuo mažesnèmis sąnaudomis parduoti savo pagamintą produkciją. Statybos buvo piginamos naudojant prastesnès ko- 
kybès, todèl pigesnes medžiagas, nesilaikant visų būtinų technologinių procesų reikalavimų. Tik darbo užmokesčiui lèšų buvo negailèta (2.6 pav. (Statistikos departamentas)).

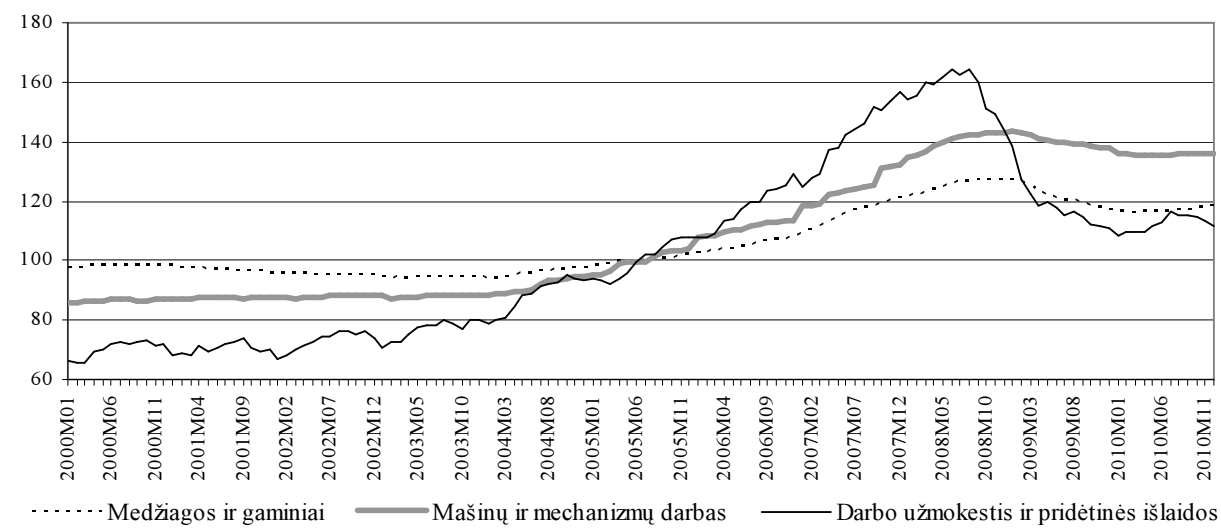

2.6 pav. Mènesiniai statybos sąnaudų kainų indeksai, palyginti su baziniu laikotarpiu, kai $2005 \mathrm{~m} .=100$

Fig. 2.6. Monthly price indices of construction costs, compared to a base period, $2005=100$

Tik sulèteję gyvenamosios statybos mastai statybos šakai leis sugrižti i normalias vėžes, kai atliekamų darbų kokybei, darbuotojų sąžiningumui, darbo našumui skiriamas reikiamas dėmesys. Darbo sąnaudų smukimas labai ryškiai žymi tiek 2000 metų, tiek šio laikotarpio ekonomikos smukimą (2.7 pav. (Eurostat)).

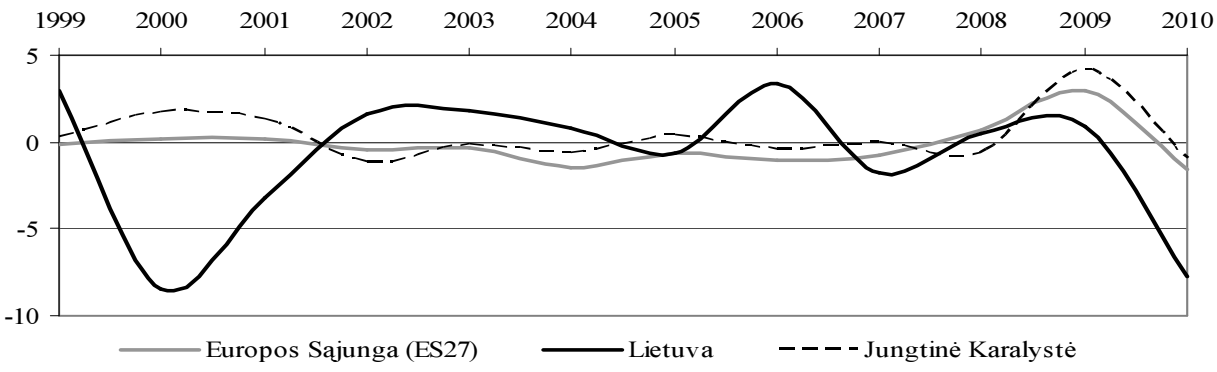

2.7 pav. Vienetinio darbo atlygio kitimas vienam darbuotojui pagal BVP to meto kainomis

Fig. 2.7. Variation of piece wages per one worker, by GDP, at then prices

Naudotojai - tai galutiniai statinio savininkai, kurie ji isigijo ir naudoja, iki kol jis pripažistamas avarinès būklès ir nugriaunamas. Vartotojas privalo užtikrinti statinio naudojimą pagal paskirti, prižiūrèti, remontuoti pagal poreikị. Ne- 
tinkama priežiūra trumpina statinio gyvavimo trukmę. Investuotojai, imdamiesi konkretaus projekto, pirmiausia atsižvelgia i vartotojų poreikius, nes būtent jie lemia objektų paklausą ir situaciją rinkoje bei užtikrina investicijų grąžą ir pelną.

$2008 \mathrm{~m}$. Lietuvos nekilnojamojo turto rinkoje ìvykęs lūžis sudaromų sandorių skaičių nubloškè trejiems metams atgal (2.8 pav.). Bendras metinis sandorių skaičius palyginti su 2007 m. buvo mažesnis trečdaliu (Registrų centras 2009).

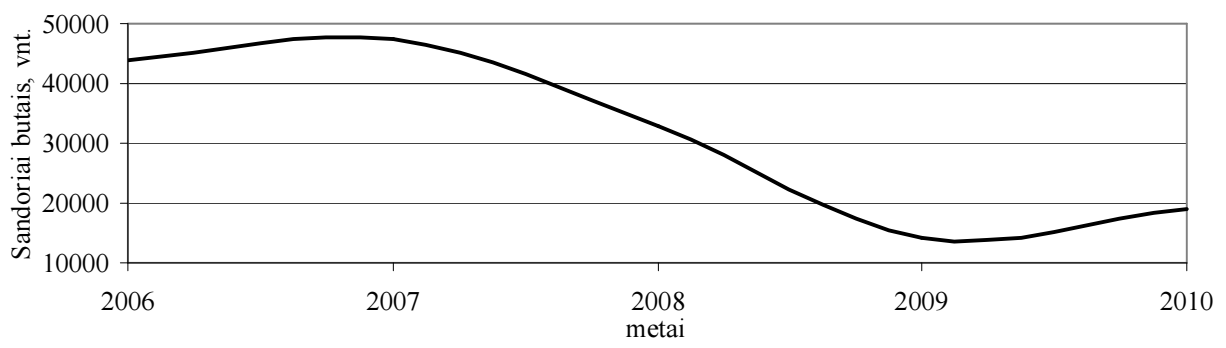

2.8 pav. Butų pirkimo/pardavimo sandorių sudarymo skaičiaus kitimas Lietuvoje $2007-2010 \mathrm{~m}$.

Fig. 2.8. Variation in the number of deals on apartment sales in Lithuania in 2007-2010

Žemès sklypų ir nekilnojamojo turto kainos suformuoja rinkos klimatą. Bet kokios statybos atveju susiduriama su teisiniais žemès santykiais - visi statiniai susiję su žeme (Lietuvos Respublikos statybos įstatymas 1996), statybos teisès igyvendinimas susijęs su teisiniu žemès statusu. Kuo žemès statusas artimesnis statybos sklypo statusui, tuo jos vertè rinkoje didesnè (2.9 pav.).

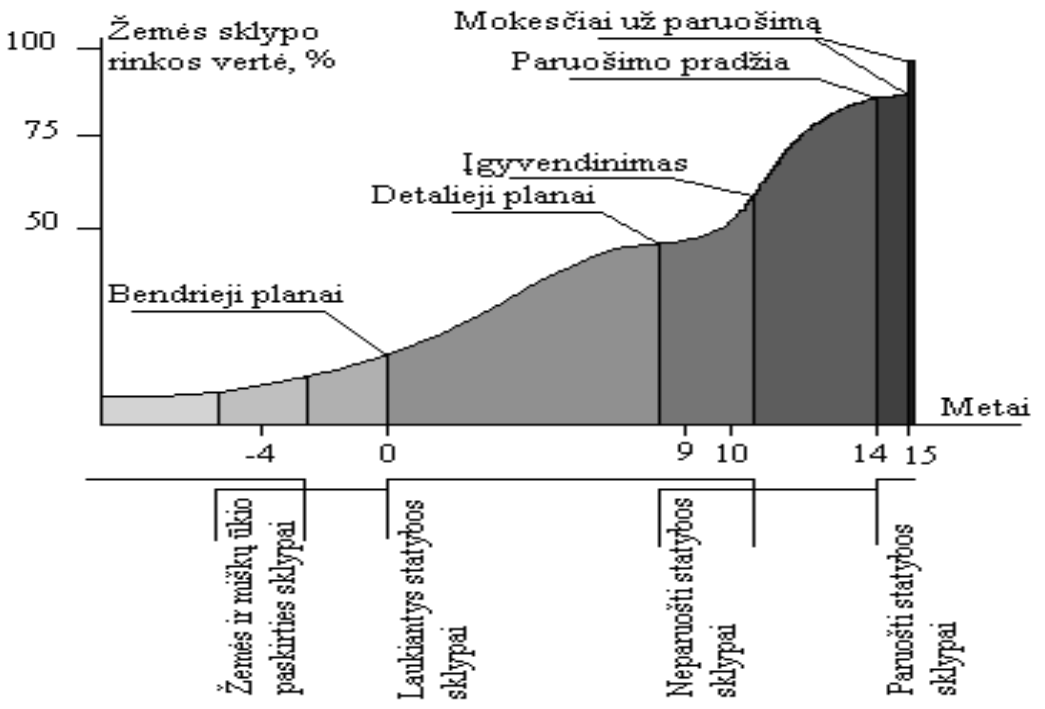

2.9 pav. Statybos sklypų kainų pokyčiai (Raslanas 2001) 
Fig. 2.9. Variation in the prices of property parcels (Raslanas 2001)

Didžiausią rinkos smukimą patyrè Šiaulių miestas, kur sandorių skaičius sumažèjo net $38 \%$. Klaipédoje sudaromų sandorių sumažejo $37 \%$, Kauno mieste $-32 \%$ (2.10 pav.), o Vilniuje - $30 \%$ (Registrų centras, 2009).

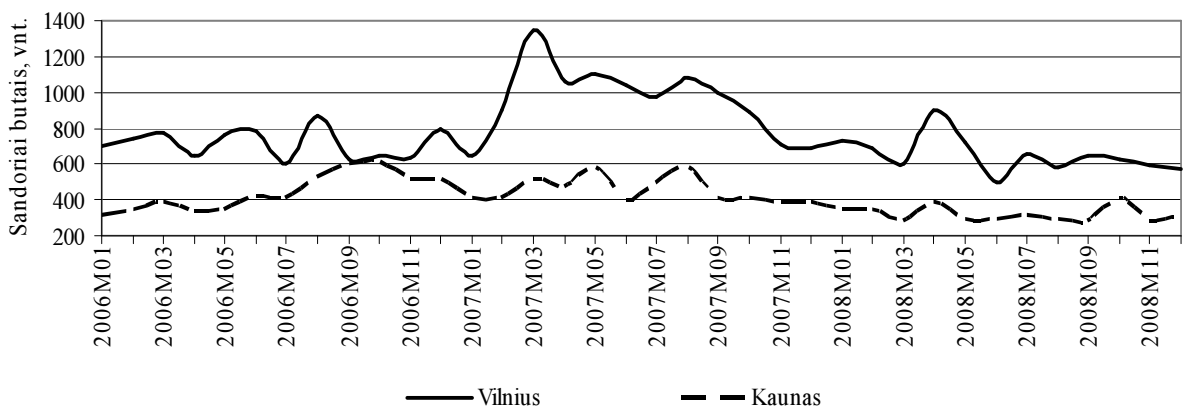

2.10 pav. Būsto pirkimo/pardavimo sandorių sudarymo skaičiaus kitimas didžiuosiuose Lietuvos miestuose 2006-2008 m.

Fig. 2.10. Variation in the number of deals on housing sales in the largest cities of Lithuania in 2006-2008

Panaši situacija susidare ir individualių namų bei žemės sklypų rinkoje (Registrų centras 2009): sandorių skaičius sumažejo Kauno mieste - $47 \%$, Vilniuje $-44 \%$ (2.11 pav.).

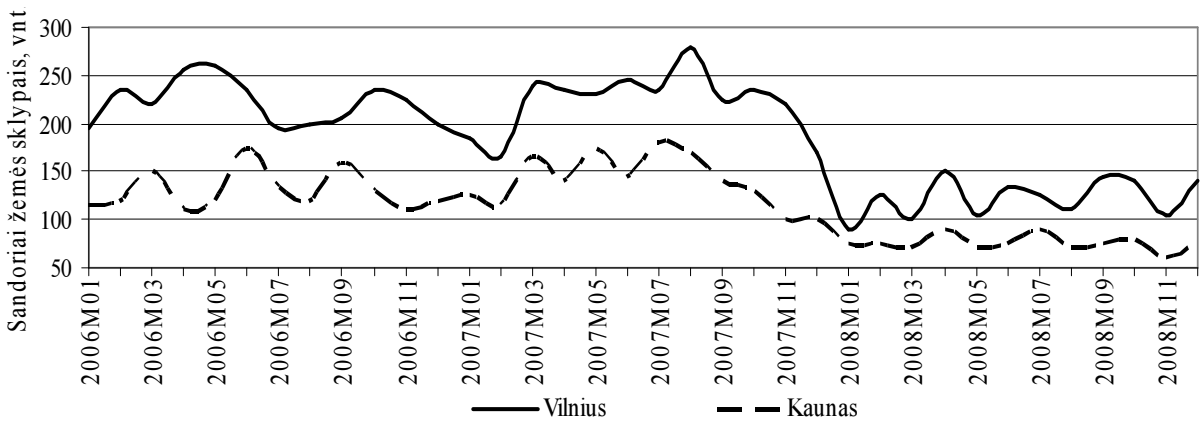

2.11 pav. Žemès sklypų pirkimo/pardavimo sandorių sudarymo skaičiaus kitimas didžiuosiuose Lietuvos miestuose 2006-2008 m.

Fig. 2.11. Variation in the number of deals on parcel sales in the largest cities of Lithuania in 2006-2008

Sumažejusios pardavimo apimtys lemia naujos statybos butų kainos kritimą ir galimą rinkos perpildymą. Nekilnojamo turto agentai pastebi pavasarinį domėjimąsi būsto pasiūla, bet pirkimo sandorių skaičius kol kas nekyla. 


\subsection{Antrojo skyriaus išvados}

1. Sukurtas koncepcinis statybos ekonominio nuosmukio aplinkoje (SENA) daugiakriterinis modelis. Išsamiai aptartos ekonominio nuosmukio aplinkos veiksnių analizès modelị sudarančios sudètinès dalys. Apibūdinta šių veiksnių itaka priklausomai nuo vartotojo poreikių.

2. Sukurta plati mikro-, mezo- ir makroveiksnių sistema, kuri apibūdina statybos projekto igyvendinimo aplinką bendro ekonominio pakilimo ir nuosmukio laikotarpiais.

3. Sukurta modelio koncepcija leidžia analizuoti statybos efektyvumo vertinimą ir didinima, taikant informacines ir intelektines technologijas, visame procese dalyvaujančias suinteresuotas grupes su savais tikslais ir aplinką veikiamą išorinių mikro-, mezo- ir makroveiksnių. 



\section{Statybos ekonominio nuosmukio aplinkoje variantinis projektavimas ir daugiakriterinè analizè}

Atliekant statybos ekonominio nuosmukio aplinkoje alternatyvų variantini projektavimą ir daugiakriterinę analizę, aprépiama gausybe informacijos, kurią reikia kompleksiškai įvertinti. Galimų alternatyvų skaičius gali siekti dešimtis tūkstančių (Zavadskas et al. 2001). Kiekviena alternatyva apibūdinama kiekybine ir kokybine informacija. Esant tokiam dideliam informacijos kiekiui alternatyvius variantus galima sudaryti automatizuotu būdu taikant alternatyvų daugiakriterinio variantinio projektavimo metodą (Kaklauskas 1999; Kaklauskas et al. 2002b; Zavadskas et al. 2003; Zavadskas et al. 2005; Banaitienè et al. 2008).

\subsection{Daugiakriterinei analizei reikalingu pradinių duomenų rengimas}

Nagrinejjant statybos galimybes įvairių suinteresuotu grupių (vyriausybès, savivaldos, i̇monès savininko, imonès darbuotojo, investuotojo) požiūriu, aiškèja ivairiopas krizès poveikis. Pavyzdžiui, susiaurejja galimybès skolintis lèšas, bet, atpigus darbams statyboje, sumažeja jų poreikis. 
Siekiant palyginti statybos galimybes ir priimamų sprendimų variantus, būtina palyginti alternatyvas. Kiekvieno sprendimo alternatyvą aprašo rodiklių visuma. Analizuojant svarbu nustatyti šių kriterijų reikšmes ir reikšmingumus.

Naudojantis rekomendacijomis, kainynais, normatyvais, žinynais, nagrinèjamais projektais, kitais informacijos šaltiniais apskaičiuojamos kiekybinių kriterijų reikšmès. Kokybinių kriterijų reikšmès dažniausiai nustatomos remiantis ekspertiniais metodais (Zavadskas et al. 2001).

Norint palyginti statybos galimybes ekonominio pakilimo ir nuosmukio sąlygomis, nagrinejjamas dviejų lygiaverčių projektų igyvendinimas 2007 ir 2009 m. (3.1 lentelè), tai yra daugiabučių namų modernizavimas (kiekvieno iš lyginamų pastatų bendrasis plotas - po $2016 \mathrm{~m}^{2}$ ).

3.1 lentelè. Daugiabučių namų modernizavimo projektų igyvendinimas, Lt

Table 3.1. Implementation of refurbishment projects for apartment buildings, LTL

\begin{tabular}{|l|c|c|}
\hline & Vytauto g. 138 2007 m. & Vytauto g. 154 2009 m. \\
\hline Darbo užmokestis & 68363,62 & 53434,41 \\
\hline Medžiagos & 297066,22 & 259681,72 \\
\hline Mechanizmai & 4206,99 & 2993,44 \\
\hline Papildomas darbo užmokestis & 5258,74 & 1602,73 \\
\hline Socialinis draudimas & 22822,93 & 17061,6 \\
\hline Statybvietės išlaidos & 14724,47 & 13390,96 \\
\hline Pridètinès išlaidos & 15795,23 & 8255,62 \\
\hline Pelnas & 13672,72 & 3564,21 \\
\hline PVM & 83963,08 & 68397,15 \\
\hline Iš viso & 525874,00 & 428381,84 \\
\hline
\end{tabular}

Atliekant statybos skirtingomis ekonominemis sąlygomis daugiakriterinę analizę tenka aprèpti didelius informacijos kiekius, todèl informacija grupuojama tam tikra tvarka - paruošiama daugiabučių namų modernizavimo projektų igyvendinimo daugiakriterinès analizès sugrupuota sprendimų prièmimų matrica (Kaklauskas et al. 2001; Kaklauskas et al. 2002a; Kaklauskas et al. 2002b; Kaklauskas et al. 2007). Jos (3.2 lentelè) stulpeliuose išreiškiamas pokytis laiko atžvilgiu, o eilutèse apibūdinama trejopa projektų igyvendinimo aplinka: makro(valstybės), mezo- (visuomenès) ar mikrolygiu (imonès, kliento). 
3.2 lentelè. Daugiabučių namų modernizavimo projektų igyvendinimo daugiakriterinès analizès sugrupuota sprendimų prièmimų matrica

Table 3.2. Grouped decision-making matrix for the multiple criteria analysis of refurbishment projects for apartment buildings

\begin{tabular}{|c|c|c|c|c|c|}
\hline \multirow{2}{*}{$\begin{array}{c}\text { Nagrinejami } \\
\text { kriterijai }\end{array}$} & $\begin{array}{c}\text { Min ar } \\
\text { max }\end{array}$ & $\begin{array}{c}\text { Mato } \\
\text { vienetai }\end{array}$ & $\begin{array}{c}\text { Reikšmingu- } \\
\text { mas }\end{array}$ & \multicolumn{2}{|c|}{ Nagrinejami projektai } \\
\cline { 4 - 6 } & $\check{z}_{1}$ & $m_{1}$ & $q_{1}$ & $x_{11}$ & $x_{12}$ \\
& $\check{z}_{2}$ & $m_{2}$ & $q_{2}$ & $x_{21}$ & $x_{22}$ \\
Makroaplinkos & $\ldots$ & $\ldots$ & $\ldots$ & $\ldots$ & $\ldots$ \\
kriterijai & $\check{z}_{i}$ & $m_{i}$ & $q_{i}$ & $x_{i 1}$ & $x_{i 2}$ \\
& $\ldots$ & $\ldots$ & $\ldots$ & $\ldots$ & $\ldots$ \\
& $\check{z}_{k}$ & $m_{k}$ & $q_{k}$ & $x_{k 1}$ & $x_{k 2}$ \\
\hline \multirow{3}{*}{ Mezoaplinkos } & $\check{z}_{k+1}$ & $m_{k+1}$ & $q_{k+1}$ & $x_{k+1}$ & $x_{k+12}$ \\
kriterijai & $\check{z}_{k+2}$ & $m_{k+2}$ & $q_{k+2}$ & $x_{k+2}$ & $x_{k+22}$ \\
& $\ldots$ & $\ldots$ & $\ldots$ & $\ldots$ & $\ldots$ \\
& $\check{z}_{i}$ & $m_{i}$ & $q_{i}$ & $x_{i 1}$ & $x_{i 2}$ \\
& $\ldots$ & $\ldots$ & $\ldots$ & $\ldots$ & $\ldots$ \\
& $\check{z}_{t}$ & $m_{t}$ & $q_{t}$ & $x_{t 1}$ & $x_{t 2}$ \\
\hline \multirow{3}{*}{ Mikroaplinkos } & $\check{z}_{t+1}$ & $m_{t+1}$ & $q_{t+1}$ & $x_{t+1}$ & $x_{t+12}$ \\
kriterijai & $\check{z}_{t+2}$ & $m_{t+2}$ & $q_{t+2}$ & $x_{t+2}$ & $x_{t+22}$ \\
& $\ldots$ & $\ldots$ & $\ldots$ & $\ldots$ & $\ldots$ \\
& $\check{z}_{i}$ & $m_{i}$ & $q_{i}$ & $x_{i 1}$ & $x_{i 2}$ \\
& $\ldots$ & $\ldots$ & $\ldots$ & $\ldots$ & $\ldots$ \\
& $\check{z}_{m}$ & $m_{m}$ & $q_{m}$ & $x_{m 1}$ & $x_{m 2}$ \\
\hline
\end{tabular}

Visais trimis lygiais kriterijai yra dvieju grupių: kiekybiniai ir kokybiniai (3.3 lentelè). Kiekybiniai kriterijai turi piniginę išraišką, o kokybiniai gali būti išreikšti procentiniais pokyčiais laike, vieta kitų lyginamujų atžvilgiu, balų, skiriamų i̇vairių sričių ekspertų kiekiu, ir panašiai. Kriterijų reikšmès, mato vienetai ir vertinimo skalès priklauso nuo informacijos rinkimo šaltinio:

LSD - Lietuvos statistikos departamentas;

ESt - Europos statistikos departamentas;

VMI - Valstybinè mokesčių inspekcija;

LB - Lietuvos bankas;

E - eksperto nuomone;

PB - Pasaulio bankas;

TI - Transparency International (Pasaulinè koalicija kovai su korupcija);

VDI - Valstybinè darbo inspekcija;

I - statybos imonès pateikti duomenys. 
3.3 lentelè. Daugiabučiu namų modernizavimo projektų vertinimo kriterijai

Table 3.3. Evaluation criteria of refurbishment projects for apartment buildings

\begin{tabular}{|c|c|c|c|}
\hline $\begin{array}{l}\text { Nagrinèjami } \\
\text { kriterijai }\end{array}$ & $\begin{array}{l}\text { Mato } \\
\text { vnt. }\end{array}$ & Apibūdinimas & $\begin{array}{c}\text { Šalti- } \\
\text { nis }\end{array}$ \\
\hline 1 & 2 & 3 & 4 \\
\hline \multicolumn{4}{|c|}{ Makroaplinkos kriterijai } \\
\hline $\begin{array}{l}\text { 1. BVP } \\
\text { augimas / } \\
\text { smukimas }\end{array}$ & $\%$ & $\begin{array}{l}\text { Valstybės bendrojo vidaus produkto augimas ar } \\
\text { smukimas turi lemiamą itaką visos ekonomikos } \\
\text { „sveikatai““. Augimas leidžia tikètis didesnès valsty- } \\
\text { bès paramos finansuojant modernizavimo darbus } \\
\text { (tuo labiau, kad valstybè deklaruoja tokią parama). }\end{array}$ & LSD \\
\hline $\begin{array}{l}\text { 2. PVM } \\
\text { standartinis } \\
\text { tarifas }\end{array}$ & $\%$ & $\begin{array}{l}\text { Iš pridètinès vertès mokesčio procento dauginama } \\
\text { bet kokių statybos darbų sąmata, todèl standartinio } \\
\text { PVM tarifo svyravimas gerokai brangina arba pigina } \\
\text { projekto vertę. }\end{array}$ & VMI \\
\hline $\begin{array}{l}\text { 3. Palūkanų } \\
\text { normos }\end{array}$ & $\%$ & $\begin{array}{l}\text { Vykdydama modernizavimo darbus įmonè ǐšaldo } \\
\text { dalį savo apyvartinių lěšu, o kai jų nepakanka tenka } \\
\text { skolintis. Modernizuojamo daugiabučio butų savi- } \\
\text { ninkai paramą gauna tik Všİ „Būsto agentūra“ patik- } \\
\text { rinus ar atlikti projekte numatyti darbai. }\end{array}$ & LB \\
\hline $\begin{array}{l}\text { 4. Mokesti- } \\
\text { nès lengvatos } \\
\text { mokant kredi- } \\
\text { tą }\end{array}$ & $\begin{array}{c}\text { balai } \\
(0 / 10)\end{array}$ & $\begin{array}{l}\text { Galimybės dalį paskolos palūkanų dengti iš sumokè- } \\
\text { to pajamų mokesčio yra finansinès naštos palengvi- } \\
\text { nimas gyventojams, tačiau savivalda praranda paja- } \\
\text { mas, kurios būtų panaudotos teritorijai vystyti / pri- } \\
\text { žiūrèti. }\end{array}$ & $\mathrm{E}$ \\
\hline $\begin{array}{l}\text { 5. Pasaulinis } \\
\text { konkurencin- } \\
\text { gumo indeksas }\end{array}$ & vieta & $\begin{array}{l}\text { Pasaulio konkurencingumo indeksas kiekvienos ša- } \\
\text { lies konkurencinguma vertina pagal dvylika veiks- } \\
\text { nių: šalies institucijos, infrastruktūra, makroekono- } \\
\text { mikos stabilumas, sveikata ir pirminis ugdymas, } \\
\text { aukštojo mokslo sistema ir profesinis ugdymas, pre- } \\
\text { kių bei darbo rinkos efektyvumas, finansų rinkos } \\
\text { išsivystymas, technologinis šalies išsivystymas, rin- } \\
\text { kos dydis, verslo pažanga bei naujovių diegimas. Šis } \\
\text { kriterijus lemia verslo galimybes. }\end{array}$ & PB \\
\hline $\begin{array}{l}\text { 6. Vartotojų } \\
\text { pasitikejjimo } \\
\text { rodiklis }\end{array}$ & $\%$ & $\begin{array}{l}\text { Tai visame pasaulyje vienoda metodologija skaičiuo- } \\
\text { jamas rodiklis, kuris parodo, kiek vartotojai yra op- } \\
\text { timistiškai arba pesimistiškai nusiteikę savo finansi- } \\
\text { nès padèties ir bendros ekonominès situacijos atžvil- } \\
\text { giu. Imonè, stabèdama ši rodikli, gali greičiau rea- } \\
\text { guoti į rinkos pokyčius, nes vartotoju pasitikejjimas } \\
\text { pradeda kristi arba kilti anksčiau negu kiti rodikliai. }\end{array}$ & LSD \\
\hline
\end{tabular}


3.3 lentelès tęsinys

\begin{tabular}{|c|c|c|c|}
\hline 1 & 2 & 3 & 4 \\
\hline $\begin{array}{l}\text { 7. Vidutinis } \\
\text { mėnesinis } \\
\text { bruto darbo } \\
\text { užmokestis }\end{array}$ & $\mathrm{Lt}$ & $\begin{array}{l}\text { Vidutinis atlyginimas apima tiesiogiai darbdavio } \\
\text { darbuotojui mokamą pagrindinị darbo užmokestį ir } \\
\text { papildomą uždarbị, įskaitant darbuotojo mokamas } \\
\text { socialinio draudimo įmokas bei gyventojų pajamų } \\
\text { mokestị. Darbuotojas suinteresuotas uždirbti dau- } \\
\text { giau, o klientas - modernizuoti savo būstą pigiau. }\end{array}$ & LSD \\
\hline $\begin{array}{l}\text { 8. Realaus } \\
\text { darbo užmo- } \\
\text { kesčio indek- } \\
\text { sas }\end{array}$ & $\%$ & $\begin{array}{l}\text { Realusis darbo užmokestis lemia vartotoju perkamają } \\
\text { galia. Darbo užmokesčio indeksas - tai santykinis } \\
\text { dydis, rodantis, kaip kinta realus darbo užmokestis, } \\
\text { lyginant su praejjusių metų atitinkamu ketvirčiu: } \\
\text { reikšmė, viršijanti } 100 \text { \%, rodo augimą laikui bėgant, } \\
\text { o nesiekianti } 100 \% \text { - sumažèjimą. }\end{array}$ & LSD \\
\hline $\begin{array}{l}\text { 9. Nedarbo } \\
\text { lygis }\end{array}$ & $\%$ & $\begin{array}{l}\text { Nedidelį nedarbo lygi ekonomikos pakilimo laiku } \\
\text { gali lemti tiesiog darbuotojų kaita ir didesnio atlygi- } \\
\text { nimo paieška. Tačiau labai didelis nedarbas, nors ir } \\
\text { pigina darbo jègą, verčia iniciatyvesnius darbingus } \\
\text { žmones migruoti i kitas šalis, darbdaviai ima jausti } \\
\text { kvalifikuotų darbuotojų trūkumą. }\end{array}$ & $\mathrm{ESt}$ \\
\hline $\begin{array}{l}\text { 10. Korupci- } \\
\text { jos suvokimo } \\
\text { indeksas }\end{array}$ & $\begin{array}{l}\text { balai } \\
(0 / 10)\end{array}$ & $\begin{array}{l}\text { Tai kompleksinis indikatorius, kuris nustatomas vers- } \\
\text { lo atstovų apklausomis ir kitais ekspertiniais tyrimais } \\
\text { (kiek korupcija yra paplitusi tarp viešojo sektoriaus } \\
\text { tarnautojų ir politiku). Statybos sektorius kartu su } \\
\text { ginklų pramone laikomi labiausiai korumpuotomis } \\
\text { ekonomikos sritimis, todèl šis rodiklis aktualus nag- } \\
\text { rinejjant daugiabučių modernizavimo projektų igy- } \\
\text { vendinimą. }\end{array}$ & TI \\
\hline $\begin{array}{l}\text { 11. Logistikos } \\
\text { paslaugų lygis }\end{array}$ & $\begin{array}{l}\text { balai } \\
(1 / 5)\end{array}$ & $\begin{array}{l}\text { Verslui siekiant pelno kokybės ir apyvartos sąskaita, } \\
\text { tikslinga specializuotis ir, pavyzdžiui, statybos įmo- } \\
\text { nei transporto paslaugas pirkti iš įmonės, kuri specia- } \\
\text { lizuojasi logistikoje. Tad galima neturèti didelio } \\
\text { transporto ūkio, o lěšas skirti statybos mechaniz- } \\
\text { mams įsigyti. }\end{array}$ & PB \\
\hline $\begin{array}{l}\text { 12. Bendra- } \\
\text { darbiavimas } \\
\text { su mokslo } \\
\text { istaigomis }\end{array}$ & balai & $\begin{array}{l}\text { Vis greitėjantys naujų konstrukcinių sprendimų, } \\
\text { technologijų ar medžiagų vystymosi tempai verčia } \\
\text { verslą sekti naujoves, diegti jas savo veikloje. Pradi- } \\
\text { nis naujovių diegimas gali būti perbrangus smulkiai } \\
\text { imonei, todėl reikalinga valstybės parama. }\end{array}$ & LSD \\
\hline $\begin{array}{l}\text { 13. Socialinès } \\
\text { rūpybos inf- } \\
\text { rastruktūra }\end{array}$ & $\begin{array}{l}\text { balai } \\
(0 / 10)\end{array}$ & $\begin{array}{l}\text { Tolydus socialinių paslaugu infrastruktūros (laikino } \\
\text { gyvenimo istaigos, dienos globos centrai, pensiona- } \\
\text { tai, socialinės reabilitacijos tarnybos) objektų išdès- } \\
\text { tymas ir veikla suteikia visuomenei galimybes laiku } \\
\text { gauti kokybiškas socialines paslaugas. }\end{array}$ & $\mathrm{E}$ \\
\hline
\end{tabular}


3.3 lentelès tęsinys

\begin{tabular}{|c|c|c|c|}
\hline 1 & 2 & 3 & 4 \\
\hline $\begin{array}{l}\text { 14. Sveikatos } \\
\text { apsaugos } \\
\text { infrastruktūra }\end{array}$ & $\begin{array}{c}\text { balai } \\
(0 / 10)\end{array}$ & $\begin{array}{l}\text { Racionalus sveikatos priežiūros infrastruktūros (ligo- } \\
\text { ninių, polikliniku, laboratoriju) plètotè leidžia vals- } \\
\text { tybei maksimaliai pigiau ir kokybiškiau suteikti gy- } \\
\text { ventojams medicinos pagalbą. }\end{array}$ & E \\
\hline $\begin{array}{l}\text { 15. Gyventojų } \\
\text { amžiaus vi- } \\
\text { durkis }\end{array}$ & metai & $\begin{array}{l}\text { Šis kriterijus gali būti traktuojamas dviprasmiškai: } \\
\text { viena vertus didelis gyventojų amžiaus vidurkis gali } \\
\text { reikšti aukšta gyvenimo kokybę, kita vertus (labiau } \\
\text { tikètina) senstančią visuomenę ir darbingo amžiaus } \\
\text { gyventojų skaičiaus mažèjimą. }\end{array}$ & LSD \\
\hline $\begin{array}{l}\text { 16. Vidutinè } \\
\text { gyvenimo } \\
\text { trukme }\end{array}$ & metai & $\begin{array}{l}\text { Kuo ilgesnè tikètina gyvenimo trukmè, tuo mažesnè } \\
\text { tikimybè, kad modernizuoti paimtas kreditas užguls } \\
\text { palikuoniu pečius. }\end{array}$ & LSD \\
\hline $\begin{array}{l}\text { 17. Gimsta- } \\
\text { mumo lygis }\end{array}$ & $\begin{array}{c}\text { vnt./ } \\
1000 \\
\text { gy- } \\
\text { vent. }\end{array}$ & $\begin{array}{l}\text { Mažas gimstamumo rodiklis neužtikrina kartų kaitos. } \\
\text { Mažejjant darbingo amžiaus gyventojų ir didejant } \\
\text { pensininku skaičiui, kyla itampa sveikatos ir sociali- } \\
\text { nio aprūpinimo sferose. }\end{array}$ & LSD \\
\hline \multicolumn{4}{|c|}{ Mezoaplinkos kriterijai } \\
\hline $\begin{array}{l}\text { 18. Statyboje } \\
\text { sukuriama } \\
\text { pridètinè vertè }\end{array}$ & $\%$ & $\begin{array}{l}\text { Viso ūkio sukuriamos pridètinès vertės dalis, tenkan- } \\
\text { ti statybos produkcijai. Vidutiniškai Europos Sajun- } \\
\text { gos šalims būdinga } 10 \% \text { statybos sektoriaus dalis } \\
\text { bendrosios pridètinès vertess sandaroje. }\end{array}$ & LSD \\
\hline $\begin{array}{l}\text { 19. Statybos } \\
\text { pasitikejjimo } \\
\text { rodiklis }\end{array}$ & $\%$ & $\begin{array}{l}\text { Visame pasaulyje vienoda metodologija skaičiuoja- } \\
\text { mas rodiklis, kuris parodo, kiek vartotojai optimistiš- } \\
\text { kai arba pesimistiškai nusiteikę konkrečiai statybos } \\
\text { sektoriaus atžvilgiu. }\end{array}$ & LSD \\
\hline $\begin{array}{l}\text { 20. Statybos } \\
\text { sąnaudų kainu } \\
\text { indeksai }\end{array}$ & $\%$ & $\begin{array}{l}\text { Statybos sąnaudų kainų indeksas - tai santykinis } \\
\text { dydis, rodantis kaip kinta bendrų sąnaudų kainos } \\
\text { lyginant su praejusių metų atitinkamu ketvirčiu: } \\
\text { reikšmei viršijus } 100 \% \text { matomas brangimas laikui } \\
\text { begant, o nesiekiant } 100 \% \text { - pigimas. }\end{array}$ & LSD \\
\hline $\begin{array}{l}\text { 21. Vidutiniš- } \\
\text { kai išduota } \\
\text { leidimų gyv. } \\
\text { pastatų staty- } \\
\text { bai } \\
\end{array}$ & vnt. & $\begin{array}{l}\text { Kadangi statybos leidimo galiojimas siekia } 10 \text { metu, } \\
\text { šis kriterijus rodo ne tik gyvenamosios statybos gy- } \\
\text { vybinguma, bet ir statytojų ateities vizijas bei poten- } \\
\text { cialą. }\end{array}$ & LSD \\
\hline $\begin{array}{l}\text { 22. Paskolos } \\
\text { būstui palūka- } \\
\text { nų normos }\end{array}$ & $\%$ & $\begin{array}{l}\text { Namų ūkiui sunku sutaupyti reikiamą sumą būstui } \\
\text { pirkti, todèl didžioji dalis sandorių ívyksta tik pasi- } \\
\text { skolinus lěšu iš banko. } 2005 \text { m. palūkanos nukrito iki } \\
\text { rekordiškai žemo lygmens, o tai lemė ir nepamatuotą } \\
\text { skolinimąsi. }\end{array}$ & LB \\
\hline
\end{tabular}


3.3 lentelès tęsinys

\begin{tabular}{|c|c|c|c|}
\hline 1 & 2 & 3 & 4 \\
\hline $\begin{array}{l}\text { 23. Vidutinis } \\
\text { ménesinis } \\
\text { bruto darbo } \\
\text { užmokestis } \\
\text { statyboje }\end{array}$ & $\mathrm{Lt}$ & $\begin{array}{l}\text { Statybų bumas (dèl atsiradusio darbo jègos trūkumo) } \\
\text { labiausiai pabrandino darbo užmokesčio sudedamają } \\
\text { dalị visoje statybos kainoje. Dėl ekonomikos sulètè- } \\
\text { jimo atlyginimai mažèjo: statybos darbai atpigo, } \\
\text { tačiau sektoriaus darbuotojai taip pat dažnai turi fi- } \\
\text { nansinių įsipareigojimų. Išaugo emigracija. }\end{array}$ & LSD \\
\hline $\begin{array}{l}\text { 24. Ateities } \\
\text { lūkesčių ten- } \\
\text { kinimas }\end{array}$ & $\begin{array}{c}\text { balai } \\
(0 / 10)\end{array}$ & $\begin{array}{l}\text { Stebint augančias kainas, žmogui kyla baimė, kad } \\
\text { ateityje bus sunkiau ísigyti norimą daiktą ar būstą. } \\
\text { Todèl jis perka čia, dabar ir su atsarga (gal reikès } \\
\text { didesnio buto), taip sukurdamas papildomą paklausa, } \\
\text { kuri atitinkamai pakelia kainą dar vienu laipteliu. }\end{array}$ & $\mathrm{E}$ \\
\hline $\begin{array}{l}\text { 25. Nerimas } \\
\text { prarasti darbą }\end{array}$ & $\begin{array}{c}\text { balai } \\
(0 / 10)\end{array}$ & $\begin{array}{l}\text { Nerimas natūraliai būdingas veikliam žmogui. Jis } \\
\text { padeda mobilizuotis siekiant tikslų. Tačiau nerimo } \\
\text { perteklius sutrikdo nuotaika, darbingumą, atsiradusi } \\
\text { didelè įtampa gali sukelti sveikatos sutrikimų. }\end{array}$ & $\mathrm{E}$ \\
\hline $\begin{array}{l}\text { 26. Nerimas } \\
\text { neužtekti } \\
\text { pajamų pragy- } \\
\text { venimui }\end{array}$ & $\begin{array}{c}\text { balai } \\
(0 / 10)\end{array}$ & $\begin{array}{l}\text { Dèl galimo pajamų trūkumo dažniau nerimauja namų } \\
\text { ùkiai auginantys vaikus. Esant ekonomikos sąstingiui } \\
\text { apie trečdalis Lietuvos gyventojų jaučia nuolatinị } \\
\text { nerimą dèl būtiniausių prekių isigijimo, mokesčių bei } \\
\text { paskolų mokejjimo. }\end{array}$ & $\mathrm{E}$ \\
\hline $\begin{array}{l}\text { 27. Saugumo } \\
\text { jausmas }\end{array}$ & $\begin{array}{c}\text { balai } \\
(0 / 10)\end{array}$ & $\begin{array}{l}\text { Saugumo jausmas apima kelias sudedamąsias dalis: } \\
\text { fizini, emocini, ekonomini saugumą ir pan. Jis svar- } \\
\text { bus tiek individui, tiek visuomenei. }\end{array}$ & $\mathrm{E}$ \\
\hline $\begin{array}{l}\text { 28. Nelegalūs } \\
\text { darbiniai } \\
\text { santykiai }\end{array}$ & $\begin{array}{l}\text { rezul- } \\
\text { taty- } \\
\text { vių } \\
\text { patik- } \\
\text { rini- } \\
\text { mų } \%\end{array}$ & $\begin{array}{l}\text { Pereinamosios ekonomikos sąlygomis visuomenė } \\
\text { dažnai nelegalų darbą vertina geriau negu nedarbą. } \\
\text { Tačiau nelegalūs darbiniai santykiai pirmiausia ma- } \\
\text { žina darbuotojo socialinį saugumą bei valstybės ga- } \\
\text { limybes surinkti mokesčius (ịvairiais skaičiavimais } \\
\text { „šešėlis“ siekia penktadalį Lietuvos BVP). }\end{array}$ & VDI \\
\hline $\begin{array}{l}\text { 29. Kvalifika- } \\
\text { cijos kėlimo } \\
\text { galimybės }\end{array}$ & $\begin{array}{c}\text { balai } \\
(0 / 10)\end{array}$ & $\begin{array}{l}\text { Kintant ir tobulëjant medžiagoms bei technologijoms } \\
\text { darbuotojas turi taip pat tobulèti. Visų pirma tuo } \\
\text { suinteresuotas darbdavys, bet svarbus ir visuomenès } \\
\text { teigiamas požiūris. }\end{array}$ & $\mathrm{E}$ \\
\hline $\begin{array}{l}\text { 30. Konkuren- } \\
\text { tų kiekis rin- } \\
\text { koje }\end{array}$ & vnt. & $\begin{array}{l}\text { Rinkos ekonomikai būdingas konkuravimas. Varto- } \\
\text { tojas gali rinktis, ieškodamas pigesnès ir kokybiškes- } \\
\text { nės paslaugos ar prekès, o paslaugu ar prekių teikejjas } \\
\text { suinteresuotas mažinti sąnaudas ir kelti kokybę, tikè- } \\
\text { damasis parduoti savo produkciją. }\end{array}$ & LSD \\
\hline $\begin{array}{l}\text { 31. Konkuren- } \\
\text { tų aktyvumas }\end{array}$ & $\begin{array}{c}\text { balai } \\
(0 / 10)\end{array}$ & $\begin{array}{l}\text { Konkurentų buvimas tame pačiame rinkos segmente } \\
\text { gali stipriai nesijausti, jei jie nėra labai aktyvūs. Ta- } \\
\text { čiau jei konkurentai taiko agresyvią rinkodaros poli- } \\
\text { tika, tai gali priversti aktyvinti veikla ar net iškreipti } \\
\text { rinkos santykius. }\end{array}$ & $\mathrm{E}$ \\
\hline
\end{tabular}


3.3 lentelès tęsinys

\begin{tabular}{|c|c|c|c|}
\hline 1 & 2 & 3 & 4 \\
\hline $\begin{array}{l}\text { 32. Potencia- } \\
\text { lių kreditorių } \\
\text { skaičius }\end{array}$ & vnt. & $\begin{array}{l}\text { Tiek gamybininkui, tiek vartotojui svarbios galimy- } \\
\text { bės gauti lèšu suplanuotai veiklai, kai nepakanka } \\
\text { nuosavų. Didesnis kreditorių skaičius rinkoje lemia } \\
\text { skolinimosi galimybes ir mažina tikètinas palūkanų } \\
\text { normas. }\end{array}$ & LSD \\
\hline $\begin{array}{l}\text { 33. Kreditorių } \\
\text { galimybės }\end{array}$ & $\begin{array}{c}\text { balai } \\
(0 / 10)\end{array}$ & $\begin{array}{l}\text { Kreditoriu pajègumas daro poveiki galimos skolini- } \\
\text { muisi sumos dydžiui bei skolos grąžinimo terminui. }\end{array}$ & $\mathrm{E}$ \\
\hline \multicolumn{4}{|c|}{ Mikroaplinkos kriterijai } \\
\hline $\begin{array}{l}\text { 34. Darbuoto- } \\
\text { jų etikos ko- } \\
\text { dekso laiky- } \\
\text { masis }\end{array}$ & $\begin{array}{c}\text { balai } \\
(0 / 10)\end{array}$ & $\begin{array}{l}\text { Pagarba ir taktas (arba jų nebuvimas) bendraujant su } \\
\text { visų grandžių imonės darbuotojais formuoja kliento } \\
\text { nuomonę apie imonę. Dažnai statybos paslaugų tei- } \\
\text { kejjų ieškoma teiraujantis aplinkoje, todèl prasta re- } \\
\text { putaciją pelnyti yra nesunku, o ją pagerinti reikia } \\
\text { daug pastangų. }\end{array}$ & $\mathrm{E}$ \\
\hline $\begin{array}{l}\text { 35. Darbuoto- } \\
\text { jų kompeten- } \\
\text { cija }\end{array}$ & $\begin{array}{l}\text { balai } \\
(0 / 10)\end{array}$ & $\begin{array}{l}\text { Kompetencija - tai darbuotojų žinios, igūdžiai, gebè- } \\
\text { jimas juos taikyti. Tai ịmonès turtas. Ir kaip bet kuris } \\
\text { turtas, jis turi būti kuo geriau naudojamas. }\end{array}$ & $\mathrm{E}$ \\
\hline $\begin{array}{l}\text { 36. Darbuoto- } \\
\text { jų patirtis }\end{array}$ & $\begin{array}{l}\text { balai } \\
(0 / 10)\end{array}$ & $\begin{array}{l}\text { İmonès patirtį sudaro jos darbuotojų patirtis, kuri } \\
\text { leidžia išvengti klaidų ar taikyti naujus sprendinius, } \\
\text { piginančius darbus arba tiesiog pagerinančius koky- } \\
\text { bę. }\end{array}$ & $\mathrm{E}$ \\
\hline $\begin{array}{l}\text { 37. Darbuoto- } \\
\text { jų lojalumas }\end{array}$ & $\begin{array}{c}\text { balai } \\
(0 / 10)\end{array}$ & $\begin{array}{l}\text { Lojalumas - tai charakteristika svarbi konkurencinè- } \\
\text { je kovoje, ypač kai įmonè dalyvauja viešuosiuose } \\
\text { konkursuose. }\end{array}$ & $\mathrm{E}$ \\
\hline $\begin{array}{l}\text { 38. Darbuoto- } \\
\text { jų iniciatyvu- } \\
\text { mas }\end{array}$ & $\begin{array}{l}\text { balai } \\
(0 / 10)\end{array}$ & $\begin{array}{l}\text { Iniciatyvumas - savanoriškas veikimas, kuris remiasi } \\
\text { kūrybingu mąstymu. Protingas iniciatyvus darbuoto- } \\
\text { jas naudingas įmonei, nes jis nelaukia nurodymų ,iš } \\
\text { viršaus“ kiekvienai savo darbo operacijai. }\end{array}$ & $\mathrm{E}$ \\
\hline $\begin{array}{l}\text { 39. Terminų } \\
\text { paisymas }\end{array}$ & $\begin{array}{l}\text { balai } \\
(0 / 10)\end{array}$ & $\begin{array}{l}\text { Kiekvieno projekto svarbi sėkmės sudedamoji dalis } \\
\text { yra igyvendinimo terminų laikymasis. Investicijos } \\
\text { nepradeda grižti, kol objektas neeksploatuojamas. Be } \\
\text { to, dažnoje sutartyje už vėlavimą būna numatytos } \\
\text { baudos. }\end{array}$ & $\mathrm{E}$ \\
\hline $\begin{array}{l}\text { 40. Tiekimų } \\
\text { kokybės ga- } \\
\text { rantijos }\end{array}$ & $\begin{array}{l}\text { balai } \\
(0 / 10)\end{array}$ & $\begin{array}{l}\text { Kokybiškas medžiagu ir gaminiu pristatymas i staty- } \\
\text { bos aikštelę lemia sklandų, nenutrūkstamą procesa, } \\
\text { leidžia tikètis kokybiško rezultato. }\end{array}$ & $\mathrm{E}$ \\
\hline $\begin{array}{l}\text { 41. Šalių } \\
\text { interesų deri- } \\
\text { nimas }\end{array}$ & $\begin{array}{c}\text { balai } \\
(0 / 10)\end{array}$ & $\begin{array}{l}\text { Projekto dalyvių tikslai gali skirtis (klientas nori } \\
\text { gauti kokybišką produktą ar paslaugą pigiau, versli- } \\
\text { ninkas - padengti išlaidas ir gauti pelno, valstybè - } \\
\text { surinkti daugiau mokesčiu), tad būtinas kompromisas } \\
\text { ir protingas interesų derinimas. }\end{array}$ & $\mathrm{E}$ \\
\hline
\end{tabular}


3.3 lentelès pabaiga

\begin{tabular}{|c|c|c|c|}
\hline 1 & 2 & 3 & \\
\hline $\begin{array}{l}\text { 42. Gyventoju } \\
\text { bendrijos } \\
\text { veikla }\end{array}$ & $\begin{array}{c}\text { balai } \\
(0 / 10)\end{array}$ & $\begin{array}{l}\text { Dažname daugiabutyje gyvena ịvairių pažiūrų ir fi- } \\
\text { nansinių galimybių žmonès. Tik apie } 20 \% \text { daugiabu- } \\
\text { čių turi bendrijas. Aktyvi bendrijos veikla leidžia } \\
\text { modernizuoti daugiabutį. }\end{array}$ & $\mathrm{E}$ \\
\hline $\begin{array}{l}\text { 43. Darbo } \\
\text { užmokestis } \\
\text { projekte }\end{array}$ & $\mathrm{Lt}$ & $\begin{array}{l}\text { Darbuotojas parduoda savo jègą ir gebejjimus darbda- } \\
\text { viui bei tikisi kuo didesnio atlygio, o darbdavys tikisi } \\
\text { kuo pigiau pagaminti produkciją ir suinteresuotas } \\
\text { mažinti darbo užmokesčio sudedamają dalị. }\end{array}$ & I \\
\hline $\begin{array}{l}\text { 44. Medžia- } \\
\text { gos projekte }\end{array}$ & $\mathrm{Lt}$ & $\begin{array}{l}\text { Projekte naudojamų medžiagu kokybė turi atitikti } \\
\text { estetinius, patvarumo bei ilgaamžiškumo reikalavi- } \\
\text { mus, o kaina pageidautina kuo mažesnè. }\end{array}$ & I \\
\hline $\begin{array}{l}\text { 45. Mecha- } \\
\text { nizmai projek- } \\
\text { te }\end{array}$ & $\mathrm{Lt}$ & $\begin{array}{l}\text { Tinkamai mechanizuojant darbo procesus taupomas } \\
\text { laikas ir keliama darbų kokybè, tačiau mechanizmai } \\
\text { kainuoja, dèvisi, jų atsipirkimas didina darbų kainą. }\end{array}$ & I \\
\hline $\begin{array}{l}\text { 46. Pridètinès } \\
\text { išlaidos pro- } \\
\text { jekte }\end{array}$ & $\mathrm{Lt}$ & $\begin{array}{l}\text { Rangovo patiriamos administracinės išlaidos (patalpų } \\
\text { išlaikymas, transportas ir pan.) ir darbo užmokestis } \\
\text { administracijos bei ūkio darbuotojams. }\end{array}$ & I \\
\hline $\begin{array}{l}\text { 47. Pelnas } \\
\text { projekte }\end{array}$ & $\mathrm{Lt}$ & $\begin{array}{l}\text { Rangovo pelno ir rizikos suma apskaičiuojama pro- } \\
\text { centiniu normatyviniu dydžiu nuo tiesioginių ir pridè- } \\
\text { tinių išlaidų. }\end{array}$ & I \\
\hline $\begin{array}{l}\text { 48. PVM } \\
\text { projekte }\end{array}$ & $\mathrm{Lt}$ & $\begin{array}{l}\text { Valstybės nustatyta pridėtinè vertė nuo bendros staty- } \\
\text { bos darbų vertès. Gali būti darbams ar paslaugoms } \\
\text { taikoma mokestinè lengvata, kuri šiame sąmatos } \\
\text { punkte neatsispindi. }\end{array}$ & I \\
\hline
\end{tabular}

Kitas nagrinejamas uždavinys: nekilnojamojo kultūros paveldo objekto parko ir statinių rekonstrukcija per ketverius metus (3.4 lentelè). Ilgalaikèje sutartyje numatytų darbų vertè siekia beveik $9,5 \mathrm{mln}$. litų.

3.4 lentelè. Kultūros paveldo Vilos parko ir statinių rekonstrukcijos igyvendinimas, Lt

Table 3.4. Restoration of the cultural heritage (Manor Park and buildings), LTL

\begin{tabular}{|l|c|c|c|c|}
\hline & $2007 \mathrm{~m}$. & $2008 \mathrm{~m}$. & $2009 \mathrm{~m}$. & $2010 \mathrm{~m}$. \\
\hline Darbo užmokestis & 441269 & 360004 & 110225 & 568160 \\
\hline Papildomas darbo užmokestis & 32339 & 28800 & 8818 & 45453 \\
\hline Medžiagos & 622958 & 505652 & 125125 & 765709 \\
\hline Mechanizmai & 50363 & 41088 & 9990 & 10852 \\
\hline Statybvietės išlaidos & 129564 & 105703 & 29348 & 134945 \\
\hline Pridètinės išlaidos & 214479 & 174981 & 48583 & 223380 \\
\hline Socialinis draudimas & 147924 & 120529 & 36903 & 204310 \\
\hline Pelnas & 128729 & 105022 & 28150 & - \\
\hline PVM & 318173 & 259520 & 75457 & 410090 \\
\hline Iš viso & 2085798 & 1701299 & 472599 & 2362899 \\
\hline
\end{tabular}


Pastaba $2010 \mathrm{~m}$. viso projekto kainai buvo pritaikytas 0,8796 koeficientas, remiantis

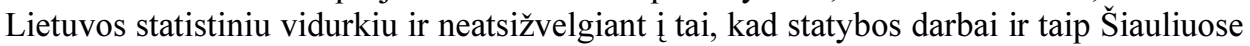
10-15 proc. pigesni, lyginant su Respublikos lygiu. Darbo užmokesčio įmonè nemažino, nes restauravimo darbams keliami ypač aukšti kokybės reikalavimai. Visas PVM padidèjimas buvo dengtas iš pelno, pridètinių ir statybvietès išlaidų.

Iš projekto igyvendinimo lyginimo analizès rezultatų formuojama sprendimų prièmimo matrica (3.5 lentelè), kurios stulpeliuose išreiškiamas kriterijų kitimas laike, o eilutèse apibūdinama trejopa projekto igyvendinimo aplinka: makro-, mezo- ar mikrolygiu.

3.5 lentelè. Kultūros paveldo Vilos parko ir statinių rekonstrukcijos igyvendinimo daugiakriterinès analizės sugrupuota sprendimų prièmimo matrica

Table 3.5. Grouped decision-making matrix for the multiple criteria analysis of the restoration of the cultural heritage (Manor Park and buildings)

\begin{tabular}{|c|c|c|c|c|c|c|c|}
\hline \multirow{2}{*}{$\begin{array}{l}\text { Nagrinèjami } \\
\text { kriterijai }\end{array}$} & \multirow{2}{*}{$\begin{array}{l}\text { Min ar } \\
\max \end{array}$} & \multirow{2}{*}{$\begin{array}{l}\text { Mato } \\
\text { viene- } \\
\text { tai }\end{array}$} & \multirow{2}{*}{$\begin{array}{l}\text { Reikš- } \\
\text { min- } \\
\text { gumas }\end{array}$} & \multicolumn{4}{|c|}{ Nagrinèjami projektai } \\
\hline & & & & $\begin{array}{c}2007 \\
\mathrm{~m} .\end{array}$ & $\begin{array}{c}2008 \\
\mathrm{~m} .\end{array}$ & $\begin{array}{c}2009 \\
\mathrm{~m} .\end{array}$ & $\begin{array}{c}2010 \\
\mathrm{~m} .\end{array}$ \\
\hline \multirow{6}{*}{$\begin{array}{c}\text { Makroaplinkos } \\
\text { kriterijai }\end{array}$} & $\check{z}_{1}$ & $m_{1}$ & $q_{1}$ & $x_{11}$ & $x_{12}$ & $x_{13}$ & $x_{124}$ \\
\hline & $\check{z}_{2}$ & $m_{2}$ & $q_{2}$ & $x_{21}$ & $x_{22}$ & $x_{23}$ & $x_{24}$ \\
\hline & $\cdots$ & $\ldots$ & $\cdots$ & $\cdots$ & $\cdots$ & $\cdots$ & $\ldots$ \\
\hline & $\check{z}_{i}$ & $m_{i}$ & $q_{i}$ & $x_{i 1}$ & $x_{i 2}$ & $x_{i 3}$ & $x_{i 4}$ \\
\hline & $\cdots$ & $\cdots$ & $\cdots$ & $\cdots$ & $\cdots$ & $\cdots$ & $\cdots$ \\
\hline & $\check{z}_{k}$ & $m_{k}$ & $q_{k}$ & $x_{k 1}$ & $x_{k 2}$ & $x_{k 3}$ & $x_{k 4}$ \\
\hline \multirow{6}{*}{$\begin{array}{c}\text { Mezoaplinkos } \\
\text { kriterijai }\end{array}$} & $\check{z}_{k+1}$ & $m_{k+1}$ & $q_{k+1}$ & $x_{k+11}$ & $x_{k+12}$ & $x_{k+13}$ & $x_{k+14}$ \\
\hline & $\check{z}_{k+2}$ & $m_{k+2}$ & $q_{k+2}$ & $x_{k+21}$ & $x_{k+22}$ & $x_{k+23}$ & $x_{k+24}$ \\
\hline & $\cdots$ & $\cdots$ & $\cdots$ & $\cdots$ & $\cdots$ & $\cdots$ & $\cdots$ \\
\hline & $\check{z}_{i}$ & $m_{i}$ & $q_{i}$ & $x_{i 1}$ & $x_{i 2}$ & $x_{i 3}$ & $x_{i 4}$ \\
\hline & $\cdots$ & $\cdots$ & $\cdots$ & $\cdots$ & $\cdots$ & $\cdots$ & $\cdots$ \\
\hline & $\check{z}_{t}$ & $m_{t}$ & $q_{t}$ & $x_{t 1}$ & $x_{t 2}$ & $x_{t 3}$ & $x_{t 4}$ \\
\hline \multirow{6}{*}{$\begin{array}{l}\text { Mikroaplinkos } \\
\text { kriterijai }\end{array}$} & $\check{z}_{t+1}$ & $m_{t+1}$ & $q_{t+1}$ & $x_{t+11}$ & $x_{t+12}$ & $x_{t+13}$ & $x_{t+14}$ \\
\hline & $\check{z}_{t+2}$ & $m_{t+2}$ & $q_{t+2}$ & $x_{t+21}$ & $x_{t+22}$ & $x_{t+23}$ & $x_{t+24}$ \\
\hline & $\ldots$ & $\ldots$ & $\cdots$ & $\ldots$ & $\cdots$ & $\ldots$ & $\ldots$ \\
\hline & $\check{z}_{i}$ & $m_{i}$ & $q_{i}$ & $x_{i 1}$ & $x_{i 2}$ & $x_{i 3}$ & $x_{i 4}$ \\
\hline & $\cdots$ & $\cdots$ & $\cdots$ & $\cdots$ & $\cdots$ & $\cdots$ & $\cdots$ \\
\hline & $\check{z}_{m}$ & $m_{m}$ & $q_{m}$ & $x_{m 1}$ & $x_{m 2}$ & $x_{m 3}$ & $x_{m 4}$ \\
\hline
\end{tabular}

Lèšų naudojimo tempa daugiausia lemia biudžetinio finansavimo vykdymas. Būtent biudžetiniai „apkarpymai“ juntami 2010 m.: pagal sutartị imoné 
turejo gauti apie 2,7 mln. Lt, o sumokèta buvo beveik 2,4 mln. Lt. Makroaplinkos kriterijai panašūs i tuos, kurie nagrinèti lyginant daugiabučių modernizavimo projektus, bet jų reikšmingumas viso valstybès finansavimo atveju didesnis.

3.6 lentelè. Kultūros paveldo Vilos parko ir statinių rekonstrukcijos projekto igyvendinimo vertinimo kriterijai

Table 3.6. Evaluation criteria of the restoration project of the cultural heritage (Manor Park and buildings)

\begin{tabular}{|c|c|c|c|}
\hline $\begin{array}{c}\text { Nagrinejjami } \\
\text { kriterijai }\end{array}$ & $\begin{array}{l}\text { Mato } \\
\text { vnt. }\end{array}$ & Apibūdinimas & \begin{tabular}{|l}
$\begin{array}{l}\text { Šal- } \\
\text { tinis }\end{array}$ \\
\end{tabular} \\
\hline 1 & 2 & 3 & 4 \\
\hline \multicolumn{4}{|c|}{ Makroaplinkos kriterijai } \\
\hline $\begin{array}{l}\text { 1. BVP au- } \\
\text { gimas / smu- } \\
\text { kimas }\end{array}$ & $\%$ & $\begin{array}{l}\text { Kultūros paveldo restauravimo darbai finansuojami iš } \\
\text { valstybès biudžeto, tad neigiamas BVP gali reikšti } \\
\text { finansavimo sutrikimus. }\end{array}$ & LSD \\
\hline $\begin{array}{l}\text { 2. PVM } \\
\text { standartinis } \\
\text { tarifas }\end{array}$ & $\%$ & $\begin{array}{l}\text { Bendra projekto sąmatinè vertė (neiskaitant kai kurios } \\
\text { irangos) vertinama skaičiuojant pridètinės vertès mo- } \\
\text { kesti. Kylant PVM tarifui, brangsta visas projektas. }\end{array}$ & VMI \\
\hline $\begin{array}{l}\text { 3. Palūkanu } \\
\text { normos }\end{array}$ & $\%$ & $\begin{array}{l}\text { Konkursą laimejjusi įmonė vykdo statybos darbus savo } \\
\text { ir skolintomis lěšomis, o mokejjimas vykdomas tik } \\
\text { valstybinès priežiūros atstovams prièmus darbus. To- } \\
\text { dèl svarbu kuo pigiau pasiskolinti lèšų. }\end{array}$ & LB \\
\hline $\begin{array}{l}\text { 4. Mokest. } \\
\text { lengvatos ūkio } \\
\text { subjektams }\end{array}$ & $\begin{array}{l}\text { balai } \\
(0 / 10)\end{array}$ & $\begin{array}{l}\text { Smulkiajam ir vidutiniam verslui skatinti vyriausybė } \\
\text { yra numačiusi mokestines lengvatas, atidedant mokes- } \\
\text { tinius i̇sipareigojimus ar atleidžiant nuo delspinigiu } \\
\text { mokejjimo. }\end{array}$ & $\mathrm{E}$ \\
\hline $\begin{array}{l}\text { 5. Pasaulinis } \\
\text { konkurencin- } \\
\text { gumo indeksas }\end{array}$ & vieta & $\begin{array}{l}\text { Pasaulio konkurencingumo indeksas kiekvienos šalies } \\
\text { konkurencingumą vertina pagal dvylika veiksnių. Šis } \\
\text { kriterijus nusako verslo ir konkurencijos aplinką: kuo } \\
\text { aukštesnę vietą užima valstybè, tuo palankesnès joje } \\
\text { verslo galimybės. }\end{array}$ & PB \\
\hline $\begin{array}{l}\text { 6. Vartotojų } \\
\text { pasitikèjimo } \\
\text { rodiklis }\end{array}$ & $\%$ & $\begin{array}{l}\text { Tai visame pasaulyje vienoda metodologija skaičiuo- } \\
\text { jamas rodiklis, parodantis, kiek vartotojai yra optimis- } \\
\text { tiškai arba pesimistiškai nusiteikę savo finansinès pa- } \\
\text { deties ir bendros ekonominès situacijos atžvilgiu. Var- } \\
\text { totojų pasitikėjimas pradeda kristi arba kilti anksčiau } \\
\text { negu kiti rodikliai. }\end{array}$ & LSD \\
\hline $\begin{array}{l}\text { 7. Vidutinis } \\
\text { ménesinis } \\
\text { bruto darbo } \\
\text { užmokestis }\end{array}$ & $\mathrm{Lt}$ & $\begin{array}{l}\text { Vidutinis atlyginimas pinigais, apimantis tiesiogiai } \\
\text { darbdavio darbuotojui mokamą pagrindini darbo už- } \\
\text { mokestị ir papildomą uždarbi, iskaitant darbuotojo } \\
\text { mokamas socialinio draudimo i̇mokas ir gyventojų } \\
\text { pajamų mokesti. Užsakovas nori pigaus, bet kokybiško } \\
\text { rezultato, o darbuotojas - teisingo atlygio. }\end{array}$ & LSD \\
\hline
\end{tabular}


3.6 lentelès tęsinys

\begin{tabular}{|c|c|c|c|}
\hline 1 & 2 & 3 & \\
\hline $\begin{array}{l}\text { 8. Realiojo } \\
\text { užmokesčio } \\
\text { indeksas }\end{array}$ & $\%$ & $\begin{array}{l}\text { Realusis darbo užmokestis atspindi vartotojų perkamą- } \\
\text { ją galią. Darbo užmokesčio indeksas rodo jo kitimą, } \\
\text { lyginant su praejusių metu atitinkamu ketvirčiu. Šio } \\
\text { indekso augimas gali reikšti darbuotojų lūkesčius dèl } \\
\text { atlyginimo padidejjimo. }\end{array}$ & LSD \\
\hline $\begin{array}{l}\text { 9. Nedarbo } \\
\text { lygis }\end{array}$ & $\%$ & $\begin{array}{l}\text { Nedarbo, susijusio su natūralia gerų darbo salygų pa- } \\
\text { ieška, procentas yra apie 5-7 \%. Tačiau viršijus } 15 \% \text { \% } \\
\text { darbdaviai ima jausti kvalifikuotu darbuotoju trūkumą } \\
\text { dèl emigracijos ir dèl to, kad ilgai nedirbantys praran- } \\
\text { da ignūdžius. }\end{array}$ & ESt \\
\hline $\begin{array}{l}\text { 10. Teritoriju } \\
\text { planavimo } \\
\text { išbaigtumas }\end{array}$ & $\begin{array}{c}\text { balai } \\
(0 / 10)\end{array}$ & $\begin{array}{l}\text { Restauravimo projektas apima ir teritorijos prie Vilos } \\
\text { atkūrimą. Projektuojant ir igyvendinant projektą priva- } \\
\text { lu remtis teritoriju planavimo sprendiniais. Todèl } \\
\text { svarbus jų išbaigtumas. }\end{array}$ & E \\
\hline $\begin{array}{l}\text { 11. Korupcijos } \\
\text { suvokimo } \\
\text { indeksas }\end{array}$ & $\begin{array}{c}\text { balai } \\
(0 / 10)\end{array}$ & $\begin{array}{l}\text { Apklausus verslo atstovus ir kitais ekspertiniais tyri- } \\
\text { mais nustatytas rodiklis, kuris parodo kiek korupcija } \\
\text { yra paplitusi tarp viešojo sektoriaus tarnautojų ir poli- } \\
\text { tikų. Statybos sektorius kartu su ginklu pramone lai- } \\
\text { komi labiausiai korumpuotomis ekonomikos šakomis. }\end{array}$ & TI \\
\hline $\begin{array}{l}\text { 12. Verslumo } \\
\text { lygis }\end{array}$ & $\begin{array}{l}\text { im. } \\
\text { sk./ } \\
1000 \\
\text { gyv. }\end{array}$ & $\begin{array}{l}\text { Smulkių imonių ar fizinių asmenų, dirbančių pagal } \\
\text { verslo liudijimus ir individualios veiklos registraciją } \\
\text { gausa rinkoje leidžia pasirinkti pigesnį subrangovą } \\
\text { specifiniams darbams vykdyti, kai rangovui nepakan- } \\
\text { ka savo pajėgumų. }\end{array}$ & LSD \\
\hline \begin{tabular}{|l|} 
13. Logistikos \\
paslaugu dalis \\
bendroje pri- \\
dètinèje vertè- \\
je
\end{tabular} & $\%$ & $\begin{array}{l}\text { Verslui būdingas specializavimasis: statybos įmonė } \\
\text { perka logistikos paslaugas iš transporto įmonès, o } \\
\text { atsilaisvinusias lěšas gali skirti savo gamybinės bazės } \\
\text { plètrai. Auganti logistikos paslaugų dalis BPV gali } \\
\text { reikšti šios šakos plètrą ir išaugusi pasirinkimą. }\end{array}$ & LSD \\
\hline \begin{tabular}{|l|} 
14. Bendra- \\
darbiavimas su \\
mokslo įst.
\end{tabular} & balai & $\begin{array}{l}\text { Restauravimas ir atkūrimas turi būti vykdomas nepa- } \\
\text { darant žalos autentiškumui. Būtina sekti naujoves } \\
\text { medžiagų ir konstrukcijų restauravimo srityje. }\end{array}$ & LSD \\
\hline $\begin{array}{l}\text { 15. Aukštujų } \\
\text { technologijų } \\
\text { produkcijos } \\
\text { dalis eksporte } \\
\end{array}$ & $\%$ & $\begin{array}{l}\text { Šis kriterijus rodo šalies ūkio pajègumą ne tik naudoti } \\
\text { pasaulyje sukurtas technologijas ir medžiagas, bet ir } \\
\text { pasiūlyti rinkai unikalius produktus, kuriuos visų pir- } \\
\text { ma išbandyti gali savos įmonès. }\end{array}$ & ESt \\
\hline $\begin{array}{l}\text { 16. Kultūros } \\
\text { infrastruktūra }\end{array}$ & $\begin{array}{c}\text { balai } \\
(0 / 10)\end{array}$ & $\begin{array}{l}\text { Dėl kultūrinio paveldo restauracijos projekto specifi- } \\
\text { kos svarbi bendra kultūrinè aplinka ir valdžios požiū- } \\
\text { ris i ją. Dažnai šis požiūris, deja, apsiriboja viešomis } \\
\text { deklaracijomis. }\end{array}$ & E \\
\hline
\end{tabular}


3.6 lentelès tęsinys

\begin{tabular}{|c|c|c|c|}
\hline 1 & 2 & 3 & 4 \\
\hline $\begin{array}{l}\text { 17. Socialinès } \\
\text { rūpybos inf- } \\
\text { rastruktūra }\end{array}$ & $\begin{array}{c}\text { balai } \\
(0 / 10)\end{array}$ & $\begin{array}{l}\text { Tolydus socialinių paslaugų infrastruktūros objektų } \\
\text { išdėstymas ir aktyvi jų veikla suteikia visuomenei } \\
\text { galimybę sumažinti socialinę itampa. }\end{array}$ & $\mathrm{E}$ \\
\hline $\begin{array}{l}\text { 18. Sveikatos } \\
\text { apsaugos } \\
\text { infrastruktūra }\end{array}$ & $\begin{array}{c}\text { balai } \\
(0 / 10)\end{array}$ & $\begin{array}{l}\text { Racionalus sveikatos priežiūros infrastruktūros išvys- } \\
\text { tymas leidžia kuo pigiau ir kokybiškiau suteikti gy- } \\
\text { ventojams medicinos pagalbą. }\end{array}$ & $\mathrm{E}$ \\
\hline $\begin{array}{l}\text { 19. Gyventojų } \\
\text { amžiaus vi- } \\
\text { durkis }\end{array}$ & metai & $\begin{array}{l}\text { Šis kriterijus gali būti traktuojamas dviprasmiškai: } \\
\text { didelis gyventojų amžiaus vidurkis gali reikšti aukštą } \\
\text { gyvenimo kokybę, bet labiau tikètina, kad jis rodo } \\
\text { senstančią visuomenę ir darbingo amžiaus gyventojų } \\
\text { skaičiaus mažejimą. }\end{array}$ & LSD \\
\hline $\begin{array}{l}\text { 9. Gimsta- } \\
\text { mumo lygis }\end{array}$ & $\begin{array}{l}\text { vnt./ } \\
1000 \\
\text { gyv. }\end{array}$ & $\begin{array}{l}\text { Mažas gimstamumo rodiklis neužtikrina kartų kaitos. } \\
\text { Visuomenės darbingosios dalies pečius užgula vis } \\
\text { didesnè socialinių ir sveikatos apsaugos išlaidų našta. }\end{array}$ & LSD \\
\hline \multicolumn{4}{|c|}{ Mezoaplinkos kriterijai } \\
\hline $\begin{array}{l}\text { 10. Statyboje } \\
\text { sukuriama } \\
\text { pridèt. vertè }\end{array}$ & $\%$ & $\begin{array}{l}\text { Viso ūkio sukuriamos pridėtinės vertès dalis, tenkanti } \\
\text { statybos produkcijai. Vidutiniškai Europos Sajungos } \\
\text { šalims būdinga } 10 \% \text { statybos sektoriaus dalis pridè- } \\
\text { tinès vertès sandaroje. }\end{array}$ & LSD \\
\hline $\begin{array}{l}\text { 11. Statybos } \\
\text { pasitikèjimo } \\
\text { rodiklis }\end{array}$ & $\%$ & $\begin{array}{l}\text { Bendra metodologija visame pasaulyje skaičiuojamas } \\
\text { rodiklis, rodantis, kaip optimistiškai arba pesimistiš- } \\
\text { kai vartotojai yra nusiteikę konkretaus statybos sekto- } \\
\text { riaus atžvilgiu. }\end{array}$ & LSD \\
\hline $\begin{array}{l}\text { 12. Statybos } \\
\text { sąaudų kainų } \\
\text { indeksai }\end{array}$ & $\%$ & $\begin{array}{l}\text { Tai santykinis dydis, rodantis kaip kinta bendrų są- } \\
\text { naudų kainos, lyginant su praejjusių metu atitinkamu } \\
\text { laikotarpiu: jei indeksas viršija } 100 \% \text { reikšmę, są- } \\
\text { naudų kainos pakilo, o nepasiekus } 100 \% \text { sąaudos } \\
\text { atpigo. }\end{array}$ & LSD \\
\hline $\begin{array}{l}\text { 13. Išduota } \\
\text { leidimų negyv. } \\
\text { past. statybai }\end{array}$ & vnt. & $\begin{array}{l}\text { Nagrinèjamas vidutinis išduodamų leidimų skaičius } \\
\text { per ketvirtị. Statybos leidimas galioja } 10 \text { metu, todèl } \\
\text { šis kriterijus rodo ne tik statybos gyvybinguma, bet ir } \\
\text { statytojų ateities vizijas bei potencialą. }\end{array}$ & LSD \\
\hline $\begin{array}{l}\text { 14. Vidutinis } \\
\text { mènesinis } \\
\text { bruto darbo } \\
\text { užmokestis } \\
\text { statyboje }\end{array}$ & Lt. & $\begin{array}{l}\text { Statybos ,aukso amžiuje“ labiausiai išaugo darbo } \\
\text { užmokestis lyginant su kitomis statybu kainos sude- } \\
\text { damosiomis dalimis. Prasidejus bendram ekonomi- } \\
\text { niam nuosmukiui, būtent ši rodiklis labiausiai smuko. }\end{array}$ & LSD \\
\hline
\end{tabular}


3.6 lentelès tęsinys

\begin{tabular}{|c|c|c|c|}
\hline 1 & 2 & 3 & 4 \\
\hline $\begin{array}{l}\text { 15. Ateities } \\
\text { lūkesčių ten- } \\
\text { kinimas }\end{array}$ & $\begin{array}{c}\text { balai } \\
(0 / 10)\end{array}$ & $\begin{array}{l}\text { Stebint augančias kainas, žmogui kyla baimė, kad } \\
\text { ateityje bus sunkiau îsigyti norimą daiktą ar būstą. } \\
\text { Todėl jis perka čia, dabar ir su atsarga (gal reikès } \\
\text { didesnio buto), taip sukurdamas papildoma paklausa, } \\
\text { kuri atitinkamai priverčia kainą pakilti dar vienu } \\
\text { laipteliu. Sudètingu ekonominiu periodu vartotojas } \\
\text { linkęs susilaikyti ir atidèti pirkimą. }\end{array}$ & $\mathrm{E}$ \\
\hline $\begin{array}{l}\text { 16. Nerimas } \\
\text { prarasti darbą }\end{array}$ & $\begin{array}{c}\text { balai } \\
(0 / 10)\end{array}$ & $\begin{array}{l}\text { Nerimas būdingas veikliam žmogui. Jis mobilizuoja } \\
\text { siekiant tikslų. Tačiau nerimo perteklius sutrikdo } \\
\text { nuotaika, darbinguma, atsiradusi didelè itampa gali } \\
\text { sukelti sveikatos sutrikimus. Nerimas prarasti darbą } \\
\text { trukdo patirti pasitenkinimą pasiektais tikslais. }\end{array}$ & E \\
\hline $\begin{array}{l}\text { 17. Nerimas } \\
\text { neužtekti } \\
\text { pajamų pragy- } \\
\text { venimui }\end{array}$ & $\begin{array}{c}\text { balai } \\
(0 / 10)\end{array}$ & $\begin{array}{l}\text { Dėl galimo pajamų trūkumo dažniau nerimauja namų } \\
\text { ūkiai auginantys vaikus. Apie trečdalis Lietuvos gy- } \\
\text { ventojų ekonominio nuosmukio laikotarpiu jaučia } \\
\text { ypač stiprų nerimą neužtekti pajamų mokesčiams ar } \\
\text { svarbiems pirkiniams. }\end{array}$ & E \\
\hline $\begin{array}{l}\text { 18. Saugumo } \\
\text { jausmas }\end{array}$ & $\begin{array}{c}\text { balai } \\
(0 / 10)\end{array}$ & $\begin{array}{l}\text { Šis jausmas gali sietis su fiziniu, emociniu, ekonomi- } \\
\text { niu saugumu ir pan. Jis svarbus ir individui, ir visuo- } \\
\text { menei. Saugiai besijaučiantis darbuotojas gali visiš- } \\
\text { kai atsiduoti darbui. }\end{array}$ & E \\
\hline $\begin{array}{l}\text { 19. Nelegalūs } \\
\text { darbiniai } \\
\text { santykiai }\end{array}$ & $\begin{array}{c}\text { rezult. } \\
\text { patik- } \\
\text { rinimu } \\
\%\end{array}$ & $\begin{array}{l}\text { Visuomenèje gaji nuostata, kad geriau dirbti nelega- } \\
\text { liai, negu visai nedirbti. Tačiau nelegalūs darbiniai } \\
\text { santykiai pirmiausia mažina socialinị darbuotojo } \\
\text { saugumą, jis sunkiai gali planuoti savo ateiti. }\end{array}$ & VDI \\
\hline $\begin{array}{l}\text { 20. Kvalifika- } \\
\text { cijos kèlimo } \\
\text { galimybès }\end{array}$ & $\begin{array}{c}\text { balai } \\
(0 / 10)\end{array}$ & $\begin{array}{l}\text { Kintant ir tobulèjant medžiagoms bei technologijoms } \\
\text { darbuotojo igūdžiai turi taip pat tobulèti. Tai vienas } \\
\text { svariausių būdų didinti produktyvumą. }\end{array}$ & $\mathrm{E}$ \\
\hline $\begin{array}{l}\text { 21. Konkuren- } \\
\text { tų skaičius } \\
\text { rinkoje }\end{array}$ & vnt. & $\begin{array}{l}\text { Esant pakankamai konkurencijai rinkoje vartotojas } \\
\text { gali rinktis, ieškodamas pigesnès bei kokybiškesnès } \\
\text { paslaugos ar prekės. Dėl paveldosauginių apribojimų } \\
\text { ši konkurencija irgi ribota. }\end{array}$ & LSD \\
\hline $\begin{array}{l}\text { 22. Konkuren- } \\
\text { tų aktyvumas }\end{array}$ & $\begin{array}{c}\text { balai } \\
(0 / 10)\end{array}$ & $\begin{array}{l}\text { Jei konkurentai nėra labai aktyvūs, galima kartais jų } \\
\text { ir nepaisyti. Tačiau konkurentai, taikantys agresyvią } \\
\text { rinkodaros politika, gali net iškreipti rinkos santy- } \\
\text { kius. }\end{array}$ & $\mathrm{E}$ \\
\hline $\begin{array}{l}\text { 23. Potencia- } \\
\text { lių kreditorių } \\
\text { skaičius }\end{array}$ & vnt. & $\begin{array}{l}\text { Nepakankant gamybai apyvartinių lèšų, svarbi gali- } \\
\text { mybe pritraukti skolintas. Didesnis kreditorių skai- } \\
\text { čius rinkoje didina šią galimybę ir mažina tikètinas } \\
\text { palūkanų normas. }\end{array}$ & LSD \\
\hline $\begin{array}{l}\text { 24. Kreditorių } \\
\text { galimybès }\end{array}$ & $\begin{array}{c}\text { balai } \\
(0 / 10)\end{array}$ & $\begin{array}{l}\text { Kreditorių pajègumas lemia galimos skolintis sumos } \\
\text { dydį ir skolos grąžinimo terminą. }\end{array}$ & E \\
\hline
\end{tabular}


3.6 lentelès tęsinys

\begin{tabular}{|c|c|c|c|}
\hline 1 & 2 & 3 & 4 \\
\hline \multicolumn{4}{|c|}{ Mikroaplinkos kriterijai } \\
\hline $\begin{array}{l}\text { 25. Darbuotojų } \\
\text { etikos kodekso } \\
\text { laikymasis }\end{array}$ & $\begin{array}{c}\text { balai } \\
(0 / 10)\end{array}$ & $\begin{array}{l}\text { Bendravimas su visu grandžių įmonès darbuotojais } \\
\text { formuoja kliento nuomonę apie imonę. Statybos sekto- } \\
\text { rius ypač jautrius reputacijos požiūriu: neigiami atsi- } \\
\text { liepimai sklinda labai greitai, o pagyrimą pelnyti sun- } \\
\text { ku. }\end{array}$ & $\mathrm{E}$ \\
\hline $\begin{array}{l}\text { 26. Darbuotojų } \\
\text { kompetencija }\end{array}$ & $\begin{array}{c}\text { balai } \\
(0 / 10)\end{array}$ & $\begin{array}{l}\text { Kompetencija - tai darbuotojų žinios, igūdžiai bei } \\
\text { gebejjimas juos taikyti. Jų išreikštosios ir neišreikšto- } \\
\text { sios žinios yra įmonès turtas. }\end{array}$ & $\mathrm{E}$ \\
\hline $\begin{array}{l}\text { 27. Darbuotojuc } \\
\text { patirtis }\end{array}$ & $\begin{array}{l}\text { balai } \\
(0 / 10)\end{array}$ & $\begin{array}{l}\text { Imonès patirti sudaro jos darbuotojų patirtis, kuri lei- } \\
\text { džia mokytis iš klaidų ar taikyti naujus sprendinius, } \\
\text { piginančius darbus arba tiesiog gerinančius kokybę. }\end{array}$ & $\mathrm{E}$ \\
\hline $\begin{array}{l}\text { 28. Darbuotojuc } \\
\text { lojalumas }\end{array}$ & $\begin{array}{c}\text { balai } \\
(0 / 10)\end{array}$ & $\begin{array}{l}\text { Lojalumas - tai darbuotojo tapatinimasis su įmone, } \\
\text { atsidavimas bendriems tikslams. }\end{array}$ & $\mathrm{E}$ \\
\hline $\begin{array}{l}\text { 29. Darbuotojų } \\
\text { iniciatyvumas }\end{array}$ & $\begin{array}{c}\text { balai } \\
(0 / 10)\end{array}$ & $\begin{array}{l}\text { Iniciatyvumas - savanoriškas veikimas, kuris remiasi } \\
\text { kūrybingu mąstymu. Protingas iniciatyvus darbuoto- } \\
\text { jas, susidūręs su problema, visų pirma bando rasti } \\
\text { sprendimą savarankiškai. }\end{array}$ & $\mathrm{E}$ \\
\hline $\begin{array}{l}\text { 30. Terminut } \\
\text { paisymas }\end{array}$ & $\begin{array}{c}\text { balai } \\
(0 / 10)\end{array}$ & $\begin{array}{l}\text { Laiku ir tinkamai atlikti darbai leidžia tikètis jų apmo- } \\
\text { kejjimo. Vèlavimas gali reikšti papildomą lěšų išaldy- } \\
\text { mą ar net (priklausomai nuo sutarties sąlygų) baudas. }\end{array}$ & $\mathrm{E}$ \\
\hline $\begin{array}{l}\text { 31. Tiekimu } \\
\text { kokybès garan- } \\
\text { tijos }\end{array}$ & $\begin{array}{c}\text { balai } \\
(0 / 10)\end{array}$ & $\begin{array}{l}\text { Kokybiškas medžiagų ir gaminių tiekimas i statybos } \\
\text { aikštelę lemia sklandǔ, nenutrūkstamą procesą bei } \\
\text { leidžia tikètis kokybiško rezultato. }\end{array}$ & $\mathrm{E}$ \\
\hline $\begin{array}{l}\text { 32. Šalių inte- } \\
\text { resų derinimas }\end{array}$ & $\begin{array}{c}\text { balai } \\
(0 / 10)\end{array}$ & $\begin{array}{l}\text { Projekto dalyvių tikslai gali skirtis: paveldosaugininkų } \\
\text { - kokybiškas ir tikslus objekto atkūrimas, verslinin- } \\
\text { kų - išlaidų padengimas ir pelnas, valstybės - mažes- } \\
\text { nis finansavimas, bet ir daugiau mokesčių. }\end{array}$ & $\mathrm{E}$ \\
\hline $\begin{array}{l}\text { 33. Darbo } \\
\text { užmokestis } \\
\text { projekte }\end{array}$ & $\mathrm{Lt}$ & $\begin{array}{l}\text { Darbuotojas parduoda savo jègą ir gebėjimus tikėda- } \\
\text { masis kuo didesnio atlygio, o darbdavys siekia kuo } \\
\text { pigiau pagaminti produkciją. Tačiau paveldosaugos } \\
\text { objektas reikalauja specifinių žinių, todèl čia ypač } \\
\text { sunku rasti pusiausvyrą. }\end{array}$ & I \\
\hline 34. Medžiagos & $\mathrm{Lt}$ & $\begin{array}{l}\text { Paveldosaugos objekte ypač aukšti medžiagų kokybès } \\
\text { bei ilgaamžiškumo reikalavimai. }\end{array}$ & I \\
\hline $\begin{array}{l}\text { 35. Mecha- } \\
\text { nizmai }\end{array}$ & $\mathrm{Lt}$ & $\begin{array}{l}\text { Tinkamai mechanizuojant darbo procesus taupomas } \\
\text { laikas ir keliama darbų kokybè, tačiau mechanizmų } \\
\text { amortizacija didina projekto kainą. }\end{array}$ & I \\
\hline $\begin{array}{l}\text { 36. Pridètinès } \\
\text { išlaidos }\end{array}$ & $\mathrm{Lt}$ & $\begin{array}{l}\text { Rangovo patiriamos administracinès išlaidos (patalpų } \\
\text { išlaikymas, transportas ir pan.) bei darbo užmokestis } \\
\text { administracijos, techniniams bei ūkio darbuotojams. }\end{array}$ & I \\
\hline
\end{tabular}


3.6 lentelés pabaiga

\begin{tabular}{|c|c|l|c|}
\hline 1 & 2 & \multicolumn{1}{|c|}{3} & 4 \\
\hline 37. Pelnas & Lt & $\begin{array}{l}\text { Rangovo pelno ir rizikos suma apskaičiuojama nuo } \\
\text { tiesioginių ir pridètinių išlaidų sumos, leidžianti eg- } \\
\text { zistuoti ir plètotis imonei. }\end{array}$ & I \\
\hline 38. PVM & Lt & $\begin{array}{l}\text { Valstybės nustatyta pridètinè vertè nuo bendros są- } \\
\text { matos sumos. Gali būti darbams ar paslaugoms nu- } \\
\text { matytų mokestinių lengvatų, kurios čia neatsispindi. }\end{array}$ & I \\
\hline
\end{tabular}

\subsubsection{Daugiabučių namų modernizavimo projektų duomenys}

Valstybè suinteresuota ir skatina daugiabučių, kuriems statyti leidimai išduoti iki 1993 m., modernizavimą. Abiejų lyginamų daugiabučių bendrijos gavo finansinę $50 \%$ paramą investiciniams projektams. Kiekvienas investicinių projektų apėmè: modernizavimo priemoniu igyvendinimo kaina, projekto parengima, rangos konkurso organizavima, techninę priežiūrą, kredito draudimą ar garantijas.

Modernizavimo darbų sudetis (3.1 pav.):

- šilumos punkto bei karšto vandens ruošimo irenginių keitimas ir rekonstravimas;

- balansinių ventilių stovams įrengimas;

- vamzdynų šiluminès izoliacijos pagerinimas;

- vamzdynu, šildymo prietaisų keitimas;

- individualios šilumos apskaitos ir termostatinių ventilių irengimas butuose;

- langų keitimas;

- lauko durų keitimas;

- langu hermetinimas;

- stogo šiltinimas;

- lodžijų istiklinimas pagal vieną projekta:

- fasadinių sienų šiltinimas;

- cokolio šiltinimas.

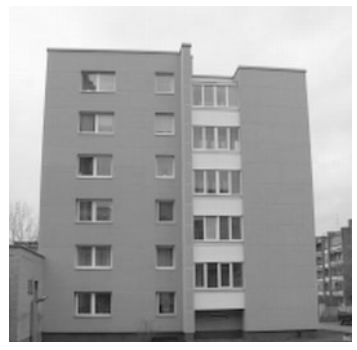

3.1 pav. 2007 m. modernizuotas daugiabutis (Vytauto g. 138, Šiauliai)

Fig. 3.1. An apartment building refurbished in 2007 (Vytauto g. 138, Šiauliai) 
Igyvendinant šiuos techniniu požiūriu labai panašius objektus, stipriai skyrèsi socialinès-ekonominès sąlygos, visa makro-, mezo- ir mikroaplinka.

Absoliučiaja reikšme visos gyvenamujų namų modernizavimo projektų eilutès $2009 \mathrm{~m}$. sumažejo, lyginant su $2007 \mathrm{~m}$. vertemis (3.2 pav.). Visas projektas atpigo $18,54 \%$. Iš to skaičiaus mažiausiai keitèsi statybvietès išlaidos, kurių pokytis - tik $9,06 \%$, daugiausia sumažejo pelnas - 73,93\%.

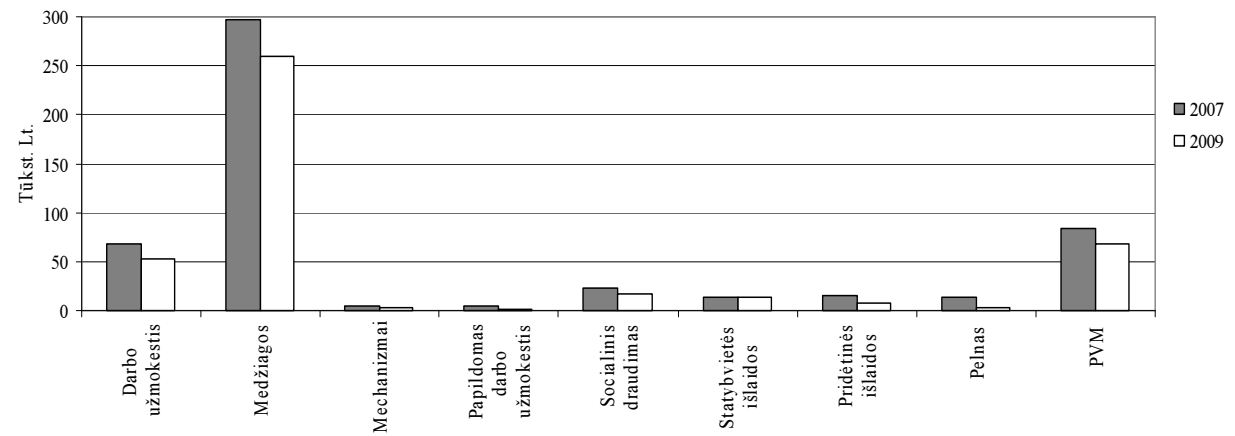

3.2 pav. Gyvenamujų namų modernizavimo 2007 ir 2009 m. projektų išlaidų pokytis Fig. 3.2. Variation of costs in refurbishment projects for residential buildings in 2007 and in 2009

Siekiant sumažinti lyginamų eilučių skaičių (tuo labiau, kad ịprasta statybos išlaidas sustambinti iki trijų sudedamujjų dalių: darbo užmokesčio, medžiagų ir mechanizmu), darbo užmokestis sumuojamas su papildomo darbo užmokesčio bei socialinio draudimo eilutèmis, o statybvietès išlaidos - su pridètinèmis. Kiekvieno iš lyginamų projektų faktinių išlaidų persiskirstymą projekto viduje lengviau sugretinti naudojant procentinę išraišką (3.3 pav.).

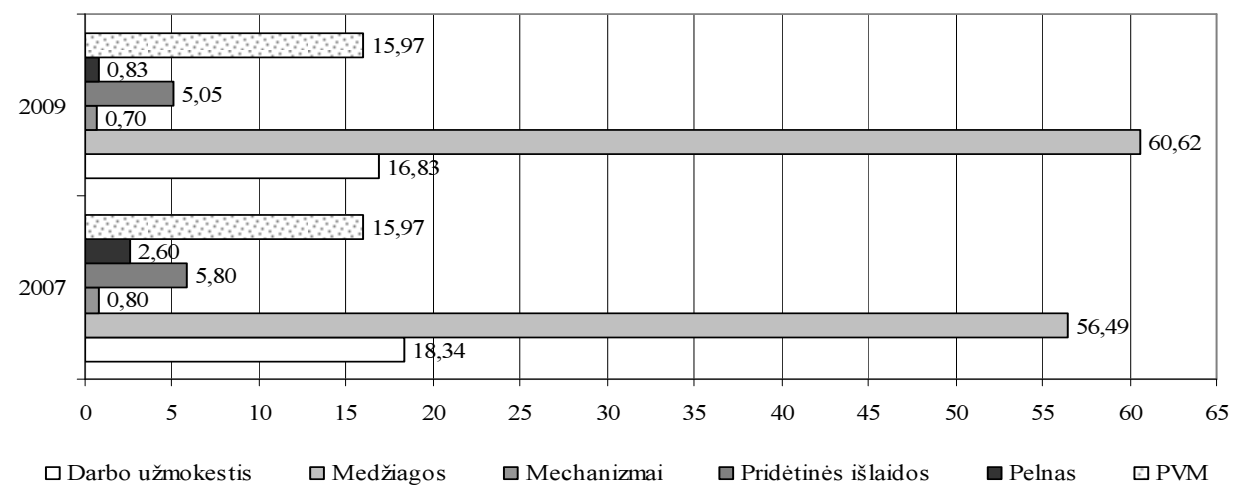

3.3 pav. Gyvenamujų namų modernizavimo 2007 ir 2009 m. projektų procentinės sandaros palyginimas

Fig. 3.3. Comparison of the percentages in the refurbishment projects for residential buildings in 2007 and in 2009 
Reikšmingą projekto kainos dali sudaro medžiagos. Iš visų statybos išlaidų sudedamujų dalių, smukus ekonomikai, išlaidos medžiagoms krito mažiausiai (2.6 pav.). Tai lèmè, kad $2009 \mathrm{~m}$. igyvendinto projekto išlaidose medžiagoms skirta dalis išaugo $4,13 \%$. Kadangi gyvenamieji namai penkiaaukščiai ir modernizuoti nereikia daug mechanizmų, tai ši eilutè kito mažiausiai $-0,1 \%$.

Kad kiekybiniai kriterijai būtų lyginami korektiškai, skaičiuojama vidutinė projekto vertè vienam butui. Daugiabučiuose yra po 22 butus, tad vieno buto savininkui $2007 \mathrm{~m}$. namo modernizavimas vidutiniškai kainavo 23903 litus, o 2009 m. - 19472 litus. Kadangi abiem atvejais bendrijos gavo valstybès parama (50\%), sumas galima padalinti dar pusiau (3.7 lentelè).

3.7 lentelè. Daugiabučių namų modernizavimo projektų igyvendinimo vidutinè kaina vieno buto savininkui

Table 3.7. Average price per one apartment owner in the refurbishment projects for apartment buildings in 2007 and in 2009

\begin{tabular}{|l|c|c|}
\hline & Vytauto g. 138; 2007 m. & Vytauto g. 154; 2009 m. \\
\hline Darbo užmokestis & 2191,94 & 1638,61 \\
\hline Medžiagos & 6751,51 & 5901,86 \\
\hline Mechanizmai & 95,61 & 68,03 \\
\hline Pridètinės išlaidos & 693,63 & 491,97 \\
\hline Pelnas & 310,74 & 81,00 \\
\hline PVM & 1908,25 & 1554,48 \\
\hline Iš viso & 11951,68 & 9735,95 \\
\hline
\end{tabular}

\subsubsection{Nekilnojamojo kultūros paveldo objekto tęstinio projek- to duomenys}

Vila su visa teritorija Šiauliuose (3.4 pav.) atitinka Nekilnojamojo kultūros paveldo įstatymo apibūdinimą: ,,architektūrinis - reikšmingais pripažinti architektūrinès kūrybos statiniai, jų dalys, priklausiniai ir tokių statinių vientisos architektūrinès kompozicijos ir (ar) vietų kompleksai, ansambliai, vietos bei vietovès“ (Nekilnojamojo kultūros paveldo apsaugos įstatymas 1994). 


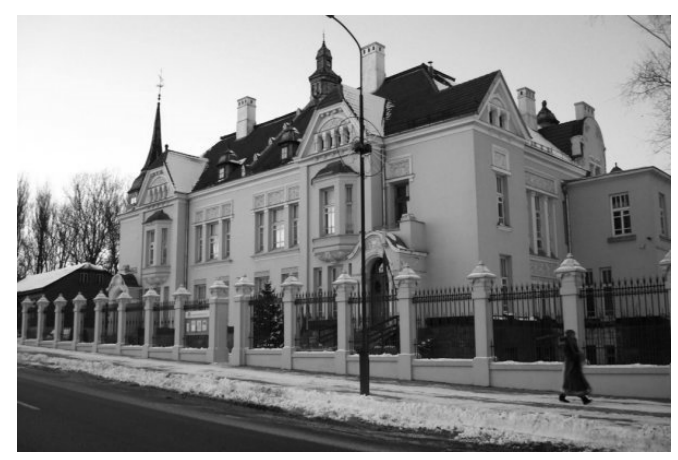

3.4 pav. Kultūrinio paveldo Vila

Fig. 3.4. Cultural heritage: the manor house

Vykdant statybos darbus kultūros paveldo objektuose yra papildomų apribojimų, susijusių su jų kultūrine ir išliekamaja verte: ypatingi reikalavimai darbų bei medžiagu kokybei (būtina užtikrinti nekilnojamojo kultūros paveldo autentiškumo išsaugojima). Kadangi nagrinejjamasis projektas yra tęstinis, tai darbai nesikartoja:

- 2007 metais ūkinio pastato atkūrimas, teritorijos aptvèrimas, lauko inžineriniai tinklai;

- 2008 metais ūkinio pastato atkūrimas, lauko inžineriniai tinklai, rūmų parko rekonstrukcija;

- 2009 metais administracinio pastato rekonstravimas, parko-sodo teritorijos atkūrimas;

- 2010 metais administracinio pastato rekonstravimas, parko-sodo teritorijos tvarkymas.

Dèl šios įvairovès tikslinga lyginti procentinès išlaidų sandaros kitimą (3.5 pav.).

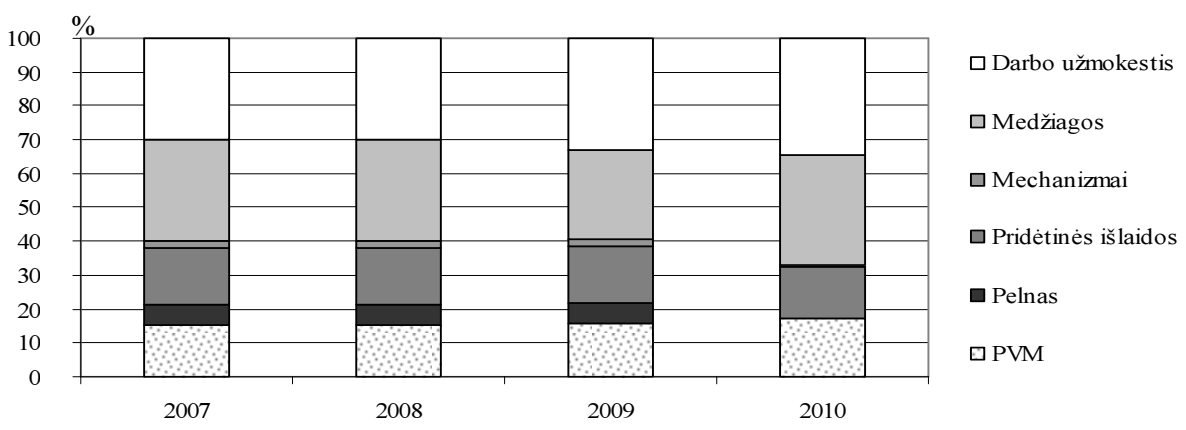

3.5 pav. Kultūrinio paveldo objekto rekonstrukcijos tęstinio projekto $2007-2010 \mathrm{~m}$. procentinès sandaros palyginimas

Fig. 3.5. Comparison of the percentages in the long-term restoration project of the cultural heritage in 2007-2010 
Lyginant atliktų darbų vertès sandarą 2007 ir 2008 m. (3.8 lentelè), ji labai panaši: skirtumai sudaro dešimtąsias ir šimtąsias procento dalis, pavyzdžiui, darbo užmokesčio sudedamoji dalis padidejjo 0,14 \%, o medžiagų - panašiai tiek pat sumažèjo. $2009 \mathrm{~m}$. darbo užmokesčio dalis projekte išaugo $3,2 \%$, medžiagu sumažèjo 3,24 \%. 2010 m. didžiausią kritimą patyre pelno eilute: nuo $6,17 \%$ 2007 ir 2008 m. kritusi iki visiško nulio 2010-aisiais.

3.8 lentelè. Vilos parko ir statiniu rekonstrukcijos tęstinio projekto $2007-2010 \mathrm{~m}$. procentinès sandaros palyginimas

Table 3.8. Comparison of the percentages in the long-term restoration project of the cultural heritage (Manor Park and buildings) in 2007-2010

\begin{tabular}{|l|c|c|c|c|}
\hline & $2007 \mathrm{~m}$. & $2008 \mathrm{~m}$. & $2009 \mathrm{~m}$. & $2010 \mathrm{~m}$. \\
\hline Darbo užmokestis (bruto) & 29,8 & 29,94 & 33,0 & 34,62 \\
\hline Medžiagos & 29,87 & 29,72 & 26,48 & 32,41 \\
\hline Mechanizmai & 2,41 & 2,42 & 2,11 & 0,46 \\
\hline Pridètinės išlaidos & 16,49 & 16,5 & 16,49 & 15,16 \\
\hline Pelnas & 6,17 & 6,17 & 5,96 & 0,00 \\
\hline PVM & 15,25 & 15,25 & 15,97 & 17,36 \\
\hline Iš viso & 100 & 100 & 100 & 100 \\
\hline
\end{tabular}

Vidutinis darbininkų užmokestis projekte nebuvo mažinamas ir siekė 2200 litų per mènesi (neatskaičius mokesčiu). Siekiant suvienodinti lyginamus duomenis, kiti kriterijai suskaičiuojami kaip procentinè išraiška projekte (3.9 lentelè), susieta su darbo užmokesčiu.

3.9 lentelè. Vilos parko ir statinių rekonstrukcijos tęstinio projekto 2007-2010 m. procentinès sandaros išraiška litais

Table 3.9. Percentages expressed in LTL for the long-term restoration project of the Manor Park and buildings in 2007-2010

\begin{tabular}{|l|c|c|c|c|}
\hline & $2007 \mathrm{~m}$. & $2008 \mathrm{~m}$. & $2009 \mathrm{~m}$. & $2010 \mathrm{~m}$. \\
\hline Darbo užmokestis & 2200,00 & 2200,00 & 2200,00 & 2200,00 \\
\hline Medžiagos & 2205,05 & 2184,10 & 1765,19 & 2059,56 \\
\hline Mechanizmai & 178,27 & 177,47 & 140,93 & 29,19 \\
\hline Pridètinès išlaidos & 1217,79 & 1212,38 & 1099,41 & 963,80 \\
\hline Pelnas & 455,65 & 453,63 & 397,12 & 0,00 \\
\hline PVM & 1126,22 & 1120,96 & 1064,51 & 1103,04 \\
\hline Iš viso & 7382,98 & 7348,55 & 6667,17 & 6355,58 \\
\hline
\end{tabular}


Pavyzdžiui, norint suskaičiuoti išlaidas medžiagoms (2007 m.), tenkančias vieno vidutinio darbininko mènesiniam apmokejjimui, vidutinis darbo užmokestis (bruto) dalijamas iš jo procentinès dalies $(29,8 \%)$ ir dauginamas iš medžiagų procentinès sudedamosios dalies $(29,87 \%)$. Šitaip suderinus lyginamus duomenis gaunama maždaug septynių tūkstančių sumos įsisavinimo projekte dinamika skirtingais laikotarpiais.

\subsection{Statybos ekonominio nuosmukio aplinkoje vertinimo kriterijų reikšmingumo nustatymas kompleksiniu metodu}

Nagrinejjama informacija yra ir kiekybinè, ir kokybinè. Norint nustatyti statybos skirtingomis ekonominemis sąlygomis galimybių vertinimo kriterijų sistemas ir reikšmingumus, taikomas kompleksinis kriterijų reikšmingumų nustatymo metodas (Zavadskas et al. 2001).

Daugiabučių gyvenamujų namų modernizavimo projektų bei tęstinio kultūros paveldo objekto rekonstravimo projekto igyvendinimo variantų kriterijų reikšmingumai nustatomi remiantis sprendimu prièmimo matrica $\boldsymbol{D}$ (pagal 3.2 ir 3.5 lenteles, A ir B priedai) ir (3.1)-(3.9) formulèmis.

1 etapas. Nustatoma kiekvieno kiekybinio (išreikšto litais) kriterijaus reikšmių suma:

$$
\boldsymbol{S}_{i}=\sum_{j=1}^{n} \boldsymbol{x}_{i j} ; i=\overline{1, \boldsymbol{m}} ; \quad j=\overline{1, n} ;
$$

čia: $x_{i j}-i$ kriterijaus reikšmė $j$ sprendimo variantu; $m$ - kriterijų skaičius; $n-$ lyginamų variantų skaičius.

Pavyzdžiui, vertinant daugiabučių namų modernizavimo (DNM) projektus, kiekybiniai kriterijai yra 7-as, 23-ias, 43-ias ir t. t.:

$\boldsymbol{S}_{7}=1891,48+2156,55=4048,03$;

$\boldsymbol{S}_{23}=2253,7+1960,73=4214,43$;

$\boldsymbol{S}_{43}=2191,94+1638,61=3830,55$; ir t. t.

Analogiškai skaičiuojami kiekybiniai kriterijai vertinant vilos parko ir statinių rekonstrukcijos (VPSR) tęstinio projekto duomenis.

2 etapas. Kiekybinių kriterijų reikšmių suma skaičiuojama taip:

$$
\boldsymbol{V}=\sum_{i=1}^{k} S_{i} ; i=\overline{1, m}
$$




$$
\begin{aligned}
& \boldsymbol{V}_{\boldsymbol{D N M}}=4048,03+4214,43+3830,55+12653,36+163,65+1185,60+ \\
& +1812,60+391,75+3462,73=29950,09 ; \\
& \text { o antruoju atveju: }
\end{aligned}
$$

$$
\begin{aligned}
& V_{V P S R}=8348,31+8452,21+8800+8213,90+525,86+4493,38+ \\
& +1306,41+4414,72=44631,50 .
\end{aligned}
$$

3 etapas. Kiekvieno iš kiekybinių kriterijų reikšmingumai nustatomi pagal formulę:

$$
\boldsymbol{q}_{i}=\frac{\boldsymbol{P}_{\boldsymbol{i}}}{\boldsymbol{V}} ; i=\overline{1, m} \text {. }
$$

Pavyzdžiui, septinto kriterijaus reikšmingumas vertinant daugiabučių namų modernizavimo projektus:

$$
\boldsymbol{q}_{7}=\frac{4048,03}{29950,09}=0,135 \text {. }
$$

Toliau skaičiuojami kokybinių kriterijų, išreikštų ivvairiomis dimensijomis, reikšmingumai.

4 etapas. Derinant tarpusavyje kiekybinių ir kokybinių kriterijų reikšmingumus, pasirenkamas lyginamasis etalonas $\boldsymbol{E}$. Ekspertai (imonès, igyvendinusios lyginamus projektus, inžinerinis personalas), lygindami daugiabučiu modernizavimo projektus, lyginamuoju etalonu pasirinko medžiagų vertę, tad skaičiuojant bus taikomas $E_{D N M}=0,422$, nagrinejjant nekilnojamojo kultūros paveldo objekto rekonstrukcijos tęstinio projekto igyvendinimą didžiausias reikšmingumas tenka darbo užmokesčiui, tada $E_{V P S R}=0,197$.

5 etapas. Projektų kokybinių kriterijų pradiniai reikšmingumai nustatyti ekspertiniais metodais. Pavyzdžiui, lyginant daugiabučių namų modernizavimo projektus nustatyta, kad šalies bendrasis vidaus produktas siektų 12 proc., todèl $p_{l}=0,120$. Nagrinejant paveldo vilos parko ir statinių rekonstrukcija, tas pats rodiklis (BVP) tampa pradiniai reikšmingas $p_{l}=0,263$.

6 etapas. Kiekvieno iš kokybinių kriterijų reikšmingumai nustatomi pagal formulę:

$$
\boldsymbol{q}_{i}=\boldsymbol{p}_{\boldsymbol{i}} \cdot \boldsymbol{E} ; \boldsymbol{i}=\boldsymbol{k}+1, \ldots, \boldsymbol{m} .
$$

Pavyzdžiui, vertinant daugiabučių namų modernizavimo projektus:

$$
\boldsymbol{q}_{1}=0,12 \cdot 0,422=0,051
$$

o vertinant Vilos parko ir statinių rekonstrukcijos projektą: 


$$
\boldsymbol{q}_{1}=0,263 \cdot 0,197=0,052
$$

\subsection{Statybos alternatyvų ekonominio nuosmukio aplinkoje vertinimas daugiakriterinio kompleksinio proporcingo ivertinimo metodu}

Nustačius kriterijų reikšmingumus, taikant projektų daugiakriterinės analizės metodą, apskaičiuojamas lyginamų variantų prioritetiškumas ir naudingumo laipsnis (Zavadskas 1987; Kaklauskas 1999; Kaklauskas et al. 2001), šis metodas pritaikomas statybos ekonominio nuosmukio aplinkoje modeliavimui.

Prioritetiškumas ir naudingumo laipsnis tiesiogiai ir proporcingai siejamas su alternatyvas apibūdinančių kriterijų sistema (tiek jų reikšmėmis, tiek reikšmingumais). Nagrinejjamų projektų alternatyvų prioritetiškumas ir reikšmingumas skaičiuojami 7-10 etapais.

7 etapas. Pradinè sprendimų prièmimo matrica $D$ normalizuojama. Kadangi lyginami kriterijai yra labai ịvairūs, kinta nuo vienetų iki tūkstantinių reikšmių ir turi ịvairius mato vienetus, tai normalizuojant jie išreiškiami bedimensiais dydžiais (3.10 ir 3.11 lentelès). Kiekvieno kriterijaus svorinè normalizuota reikšmè apskaičiuojama taip:

$$
d_{i j}=\frac{x_{i j} \cdot q_{i}}{\sum_{j=1}^{n} x_{i j}} ; i=\overline{1, m} ; j=\overline{1, n}
$$

čia: $x_{i j}-i$ kriterijaus reikšmè $j$ sprendimo variantu; $m$ - kriterijų skaičius; $n-$ lyginamų variantų skaičius; $q_{i}-i$ kriterijaus reikšmingumas.

Taip skaičiuojant bendrojo vidaus produkto augimo/smukimo kriterijaus 2007 m. normalizuota reikšmė daugiabučių namų modernizavimo projektų vertinimo matricoje:

$$
d_{11}=\frac{109,8 \cdot 0,051}{109,8+85,3}=0,0287 \text {; }
$$

o $2009 \mathrm{~m}$.:

$$
d_{11}=\frac{85,3 \cdot 0,051}{109,8+85,3}=0,0223 \text {. }
$$

Kadangi kiekvieno kriterijaus reikšmingumo $q_{i}$ reikšmè proporcingai paskirstoma visiems alternatyviems variantams $a_{j}$, atsižvelgiant i jų reikšmes $x_{i j}$, tai 
kriterijaus $x_{i}$ gautų bedimensių ịvertintų reikšmių $d_{i j}$ suma visada lygi šio kriterijaus reikšmingumui $q_{i}$ :

$$
\boldsymbol{q}_{i}=\sum_{j=1}^{n} d_{i j}, i=\overline{1, m} ; j=\overline{1, n} .
$$

8 etapas. Apskaičiuojamos $j$ variantą apibūdinančių minimizuojančių (jų mažesnè reikšmè yra geresnè, pavyzdžiui, PVM standartinis tarifas, palūkanų normos ir t. t.) $S_{-j}$ ir maksimizuojančiu (didesnè jų reikšmė yra geresnè, tokios kaip BVP augimas, mokestinès lengvatos mokant kreditą ir t. t.) $S_{+j}$ ivertintų normalizuotų rodiklių sumos. Jos apskaičiuojamos pagal šias formules:

$$
\begin{gathered}
\boldsymbol{S}_{+j}=\sum_{i=1}^{k} \boldsymbol{d}_{+i j} ; \\
\boldsymbol{S}_{-j}=\sum_{i=1}^{k} \boldsymbol{d}_{-i j} ; i=\overline{1, \boldsymbol{m}} ; j=\overline{1, \boldsymbol{n}} .
\end{gathered}
$$

Pavyzdžiui, lyginant kultūros paveldo Vilos parko ir statinių rekonstrukcijos projekto igyvendinima, $2007 \mathrm{~m}$. normalizuotų maksimizuojančių rodiklių suma (D priedas):

$$
\begin{aligned}
& \boldsymbol{S}_{+j}=0,0143+0,016+0,0107+0,0424+0,0146+0,01+0,0102+ \\
& +0,011+0,0123+0,0105+0,0059+0,013+0,0098+0,0154+0,0096+ \\
& +0,023+0,0335+0,0117+0,0504+0,0176+0,0095+0,0331+0,0205+ \\
& +0,0428+0,0149+0,0361+0,0503+0,0119+0,014+0,0236+0,0312+ \\
& +0,0279+0,0492+0,0494+0,0041+0,0274+0,0101=0,7979 ;
\end{aligned}
$$

o normalizuotų minimizuojančių rodiklių suma:

$$
\begin{aligned}
& \boldsymbol{S}_{-j}=0,0097+0,0106+0,0057+0,0039+0,0089+0,0386+0,004+ \\
& +0,0067+0,0181+0,0086+0,01+0,0253=0,1501 .
\end{aligned}
$$


3.10 lentelè. Daugiabučių namų modernizavimo projektų igyvendinimo daugiakriterinès analizès normalizuota sprendimų prièmimų matrica

Table 3.10. Normalised decision-making matrix for the multiple criteria analysis of the refurbishment projects for apartment buildings

\begin{tabular}{|c|c|c|c|}
\hline \multirow{2}{*}{$\begin{array}{l}\text { Nagrinèjami } \\
\text { kriterijai }\end{array}$} & \multirow{2}{*}{ Min ar max } & \multicolumn{2}{|c|}{ Nagrinėjami projektai } \\
\hline & & $2007 \mathrm{~m}$. & $2009 \mathrm{~m}$. \\
\hline \multirow{6}{*}{ Makroaplinkos kriterijai } & $\check{z}_{1}$ & $d_{11}$ & $d_{12}$ \\
\hline & $\check{z}_{2}$ & $d_{21}$ & $d_{22}$ \\
\hline & $\ldots$ & $\ldots$ & $\ldots$ \\
\hline & $\check{z}_{i}$ & $d_{i 1}$ & $d_{i 2}$ \\
\hline & $\ldots$ & $\ldots$ & $\ldots$ \\
\hline & $\check{z}_{k}$ & $d_{k 1}$ & $d_{k 2}$ \\
\hline \multirow{6}{*}{ Mezoaplinkos kriterijai } & $\check{z}_{k+1}$ & $d_{k+11}$ & $d_{k+12}$ \\
\hline & $\check{z}_{k+2}$ & $d_{k+21}$ & $d_{k+22}$ \\
\hline & $\ldots$ & $\ldots$ & $\ldots$ \\
\hline & $\check{z}_{i}$ & $d_{i 1}$ & $d_{i 2}$ \\
\hline & $\ldots$ & $\ldots$ & $\ldots$ \\
\hline & $\check{z}_{t}$ & $d_{t 1}$ & $d_{12}$ \\
\hline \multirow{6}{*}{ Mikroaplinkos kriterijai } & $\check{z}_{t+1}$ & $d_{t+11}$ & $d_{t+12}$ \\
\hline & $\check{z}_{t+2}$ & $d_{t+21}$ & $d_{t+22}$ \\
\hline & $\cdots$ & $\cdots$ & $\cdots$ \\
\hline & $\check{z}_{i}$ & $d_{i 1}$ & $d_{i 2}$ \\
\hline & $\cdots$ & $\cdots$ & $\cdots$ \\
\hline & $\check{z}_{m}$ & $d_{m 1}$ & $d_{m 2}$ \\
\hline \multicolumn{2}{|c|}{ Maksimizuojančių normalizuotų įvertintų rodiklių suma } & $S_{+1}$ & $S_{+2}$ \\
\hline \multicolumn{2}{|c|}{ Minimizuojančių normalizuotų įvertintų rodiklių suma } & $S_{-1}$ & $S_{-2}$ \\
\hline \multicolumn{2}{|c|}{ Projekto igyvendinimo varianto reikšmingumas } & $Q_{1}$ & $Q_{2}$ \\
\hline \multicolumn{2}{|c|}{ Projekto igyvendinimo varianto prioritetiškumas } & $P_{1}$ & $P_{2}$ \\
\hline \multicolumn{2}{|c|}{ Projekto igyvendinimo varianto naudingumo laipsnis } & $N_{1}$ & $N_{2}$ \\
\hline
\end{tabular}

Šie rodikliai išreiškia nagrinèjamų projektų variantų tikslų pasiekimo laipsnị: kuo didesnè $S_{+j}$ reikšmè ir kuo mažesnè $-S_{-j}$, tuo labiau tenkinami suinteresuotu grupių poreikiai. 
3.11 lentelè. Kultūros paveldo vilos parko ir statinių rekonstrukcijos igyvendinimo daugiakriterinès analizès normalizuota sprendimų prièmimų matrica

Table 3.11. Normalised decision-making matrix for the multiple criteria analysis of the restoration of the cultural heritage (Manor Park and buildings)

\begin{tabular}{|c|c|c|c|c|c|}
\hline \multirow[b]{2}{*}{ Nagrinèjami kriterijai } & \multirow[b]{2}{*}{ Min ar max } & \multicolumn{4}{|c|}{ Nagrinèjami projektai } \\
\hline & & $\begin{array}{c}2007 \\
\mathrm{~m} .\end{array}$ & $\begin{array}{c}2008 \\
\mathrm{~m} .\end{array}$ & $\begin{array}{c}2009 \\
\mathrm{~m}\end{array}$ & $\begin{array}{l}2010 \\
\mathrm{~m}\end{array}$ \\
\hline \multirow{6}{*}{$\begin{array}{l}\text { Makroaplinkos kriteri- } \\
\text { jai }\end{array}$} & $\check{z}_{1}$ & $d_{11}$ & $d_{12}$ & $d_{13}$ & $d_{124}$ \\
\hline & $\check{z}_{2}$ & $d_{21}$ & $d_{22}$ & $d_{23}$ & $d_{24}$ \\
\hline & $\ldots$ & $\ldots$ & $\ldots$ & $\ldots$ & $\ldots$ \\
\hline & $\check{z}_{i}$ & $d_{i 1}$ & $d_{i 2}$ & $d_{i 3}$ & $d_{i 4}$ \\
\hline & $\ldots$ & $\ldots$ & $\ldots$ & $\ldots$ & $\ldots$ \\
\hline & $\check{z}_{k}$ & $d_{k 1}$ & $d_{k 2}$ & $d_{k 3}$ & $d_{k 4}$ \\
\hline \multirow{6}{*}{$\begin{array}{l}\text { Mezoaplinkos kriteri- } \\
\text { jai }\end{array}$} & $\check{z}_{k+1}$ & $d_{k+11}$ & $d_{k+12}$ & $d_{k+13}$ & $d_{k+14}$ \\
\hline & $\check{z}_{k+2}$ & $d_{k+21}$ & $d_{k+22}$ & $d_{k+23}$ & $d_{k+24}$ \\
\hline & $\cdots$ & $\cdots$ & $\cdots$ & $\cdots$ & $\cdots$ \\
\hline & $\check{z}_{i}$ & $d_{i 1}$ & $d_{i 2}$ & $d_{i 3}$ & $d_{i 4}$ \\
\hline & $\ldots$ & $\ldots$ & $\ldots$ & $\ldots$ & $\ldots$ \\
\hline & $\check{z}_{t}$ & $d_{t 1}$ & $d_{t 2}$ & $d_{t 3}$ & $d_{t 4}$ \\
\hline \multirow{6}{*}{$\begin{array}{l}\text { Mikroaplinkos kriteri- } \\
\text { jai }\end{array}$} & $\check{z}_{t+1}$ & $d_{t+11}$ & $d_{t+12}$ & $d_{t+13}$ & $d_{t+14}$ \\
\hline & $\check{z}_{t+2}$ & $d_{t+21}$ & $d_{t+22}$ & $d_{t+23}$ & $d_{t+24}$ \\
\hline & $\cdots$ & $\cdots$ & $\cdots$ & $\cdots$ & $\cdots$ \\
\hline & $\check{z}_{i}$ & $d_{i 1}$ & $d_{i 2}$ & $d_{i 3}$ & $d_{i 4}$ \\
\hline & $\ldots$ & $\ldots$ & $\ldots$ & $\ldots$ & $\ldots$ \\
\hline & $\check{z}_{m}$ & $d_{m 1}$ & $d_{m 2}$ & $d_{m 3}$ & $d_{m 4}$ \\
\hline \multicolumn{2}{|c|}{$\begin{array}{l}\text { Maksimizuojančių normalizuotų ịvertintų ro- } \\
\text { diklių suma }\end{array}$} & $S_{+1}$ & $S_{+2}$ & $S_{+3}$ & $S_{+4}$ \\
\hline \multicolumn{2}{|c|}{$\begin{array}{l}\text { Minimizuojančių normalizuotų ịvertintų rodik- } \\
\text { lių suma }\end{array}$} & $S_{-1}$ & $S_{-2}$ & $S_{-3}$ & $S_{-4}$ \\
\hline \multicolumn{2}{|c|}{ Lèšų naudojimo varianto reikšmingumas } & $Q_{1}$ & $Q_{2}$ & $Q_{3}$ & $Q_{4}$ \\
\hline \multicolumn{2}{|c|}{ Lèšų naudojimo varianto prioritetiškumas } & $P_{1}$ & $P_{2}$ & $P_{3}$ & $P_{4}$ \\
\hline \multicolumn{2}{|c|}{ Lėšų naudojimo varianto naudingumo laipsnis } & $N_{1}$ & $N_{2}$ & $N_{3}$ & $N_{4}$ \\
\hline
\end{tabular}

9 etapas. Remiantis kiekvieno iš lyginamų projektų teigiamomis $S_{+j}$ ir neigiamomis $S_{-j}$ savybėmis nustatomas variantų santykinis reikšmingumas (C ir D priedai): 


$$
Q_{j}=S_{+j}+\frac{S_{-\min } \cdot \sum_{j=1}^{n} S_{-j}}{S_{-j} \cdot \sum_{j=1}^{n} \frac{S_{-\min }}{S_{-j}}}, \quad j=\overline{1, n} ;
$$

čia $\mathrm{S}_{-\min }$ - mažiausia minimizuojančių įvertintų normalizuotų rodiklių suma.

Taigi kultūros paveldo vilos parko ir statinių rekonstrukcijos $2007 \mathrm{~m}$. projekto santykinis reikšmingumas:

$$
\boldsymbol{Q}_{1}=0,7979+\frac{0,1501 \cdot(0,1501+0,1683+0,1788+0,1747)}{0,1501 \cdot\left(\frac{0,1501}{0,1501}+\frac{0,1501}{0,1683}+\frac{0,1501}{0,1788}+\frac{0,1501}{0,1747}\right)}=0,9651 .
$$

Nagrinejjamos alternatyvos didesnis santykinis reikšmingumas $Q_{j}$ pakelia ją i aukštesnę vietą pagal prioritetiškumą $P_{j}$.

Remiantis išnagrinètu metodu gana paprasta įvertinti ir išrinkti racionaliausias lyginamų variantų sudètinių dalių alternatyvas, aiškiai matant fizinę šio proceso prasmę. Suformuojamas apibendrintas (santykinis) reikšmingumas $Q_{j}$, kuris tiesiogiai ir proporcingai priklauso nuo lyginamų kriterijų reikšmių $x_{i j}$ ir reikšmingumu $q_{i}$, turi santykinę itaką galutiniam rezultatui. Jis rodo suinteresuotų grupių tikslų ir poreikių pasiekimo lygį. Efektyviausio varianto reikšmingumas $Q_{\max }$ yra didžiausias. Visų kitų likusių variantų reikšmingumai mažesni, t. y. suinteresuotų grupių tikslai ir poreikiai tenkinami blogiau.

10 etapas. Lyginami variantai gali skirtis labai nedaug, o gali ir gerokai lenkti vienas kita. Š skirtumą lengviau ịvertinti, kai nustatomas alternatyvų naudingumo laipsnis $N_{j}$. Teigiama, kad racionaliausio varianto naudingumo laipsnis yra $100 \%$, o kitų nagrinejjamų variantų naudingumo laipsnis nustatomas pagal tokią formulę:

$$
N_{j}=\frac{\boldsymbol{Q}_{j}}{\boldsymbol{Q}_{\max }} \cdot 100 \% .
$$

Pavyzdžiui, lyginant paveldo parko vilos ir statinių rekonstrukcijos projekto igyvendinimą, alternatyvų naudingumo laipsnis skaičiuojamas:

$$
N_{2}=\frac{0,9381}{0,9651} \cdot 100 \%=97,2 \% \text { ir t. t. }
$$

Skaičiavimų rezultatai pateikiami B ir C prieduose. 


\subsection{Skaičiavimo rezultatų palyginimas su atliktais TOPSIS metodu}

Norint patikrinti skaičiavimų korektiškuma, Vilos parko ir statinių rekonstrukcijos projekto duomenys buvo panaudoti skaičiuojant TOPSIS metodu (Antuchevičienè 2005).

Hwang ir Yoon (1981) sukūrè alternatyvu prioriteto nustatymo teorija, kuri teigia, kad potencialiai geriausia alternatyva yra mažiausiai nutolusi nuo idealaus sprendinio ir labiausiai nutolusi nuo idealiai neigiamo (blogiausio) sprendinio. Ši teorija vadinama variantu prioriteto nustatymo pagal artumo idealiam taškui kriterijų metodu (angl. TOPSIS - Technique for Order Preference by Similarity to Ideal Solution).

Klasikiniame TOPSIS metode pradinès sprendimu prièmimo matricos skirtingų dimensijų rodiklių palyginimui naudojamas vektorinis normalizavimas:

$$
\boldsymbol{r}_{i j}=\frac{\boldsymbol{x}_{i j}}{\sqrt{\sum_{j=1}^{n} x_{i j}^{2}}} ; \quad i=\overline{1, \boldsymbol{m}} ; j=\overline{1, n} ;
$$

čia $r_{i j}$ yra normalizuotas matricos elementas.

Kiekvieną normalizuotos matricos elementą dauginant iš atitinkamo rodiklio reikšmingumo, sudaroma pasverta normalizuota sprendimų prièmimo matrica:

$$
v_{i j}=q_{i} \cdot r_{i j} ; i=\overline{1, m} ; j=\overline{1, n} ;
$$

TOPSIS metodo išskirtinis bruožas, kad nèra jokių apribojimų, nustatant rodiklių reikšmingumus ir rodiklių reikšmingumų suma nebūtinai turi būti lygi vienetui (Dejus 2002).

Nustatomas idealusis variantas (Zavadskas et al. 2001):

$$
\boldsymbol{a}^{*}=\left\{\left(\max _{j} v_{i j} \mid \boldsymbol{i} \in \boldsymbol{I}\right),\left(\min _{j} v_{i j} \mid \boldsymbol{i} \in \boldsymbol{I}^{\prime}\right), \boldsymbol{j}=\overline{1, \boldsymbol{n}}\right\}=\left\{\boldsymbol{v}_{1^{*}}, v_{2^{*}}, \ldots, v_{\boldsymbol{n}^{*}}\right\} \text {; }
$$

ir neigiamai idealus variantas:

$$
\boldsymbol{a}^{-}=\left\{\left(\min _{j} v_{i j} \mid \boldsymbol{i} \in \boldsymbol{I}\right),\left(\max _{j} v_{i j} \mid \boldsymbol{i} \in \boldsymbol{I}^{\prime}\right), j=\overline{1, n}\right\}=\left\{v_{1^{-}}, v_{2^{-}}, \ldots, v_{n^{-}}\right\} ;
$$

čia $I=\{i=1,2,3, \ldots, m\}-$ maksimizuojamų rodiklių aibè, $I^{\prime}=\{i=1,2,3, \ldots$, $m\}$ - minimizuojamų rodiklių aibè. 
Nustatomas kiekvienos alternatyvos artumas idealiajam variantui:

$$
\boldsymbol{S}_{j^{*}}=\sqrt{\sum_{i=1}^{m}\left(v_{i j}-v_{i^{*}}\right)^{2}} ; \boldsymbol{j}=\overline{1, n} ;
$$

Nustatomas kiekvienos alternatyvos artumas neigiamai idealiam variantui:

$$
\boldsymbol{S}_{\boldsymbol{j}^{-}}=\sqrt{\sum_{i=1}^{m}\left(v_{i j}-v_{i^{-}}\right)^{2}} ; \boldsymbol{j}=\overline{1, \boldsymbol{n}} .
$$

Nustatomas santykinis kiekvienos alternatyvos artumas idealiajam variantui:

$$
C_{j^{*}}=\frac{S_{j^{-}}}{S_{j^{*}}+S_{j^{-}}} ; j=\overline{1, n}
$$

čia $0 \leq C_{j^{*}} \leq 1$.

Geriausia alternatyva yra ta, kurios $C_{j *}$ reikšmė didžiausia.

3.12 lentelè. Vilos parko ir statinių rekonstrukcijos projekto igyvendinimo variantų vertinimo palyginimas

Table 3.12. Manor Park and buildings reconstruction project options assessment comparison

\begin{tabular}{|l|c|c|c|c|}
\hline & \multicolumn{5}{|c|}{ Nagrinèjami projektai } \\
\cline { 2 - 5 } & $2007 \mathrm{~m}$. & $2008 \mathrm{~m}$. & $2009 \mathrm{~m}$. & $2010 \mathrm{~m}$. \\
\hline \multicolumn{5}{|c|}{ Skaičiavimų COPRAS metodu rezultatai } \\
\hline Varianto reikšmingumas $Q_{j}$ & 0,9651 & 0,9381 & 0,8973 & 0,9188 \\
\hline Varianto prioritetiškumas $P_{j}$ & $\mathbf{1}$ & $\mathbf{2}$ & $\mathbf{4}$ & $\mathbf{3}$ \\
\hline Varianto naudingumo laipsnis $N_{j}$ & $100 \%$ & $97,2 \%$ & $92,97 \%$ & $95,2 \%$ \\
\hline \multicolumn{5}{|c|}{ Skaičiavimu TOPSIS metodu rezultatai } \\
\hline Varianto reikšmingumas $C_{j^{*}}$ & 0,5776 & 0,5119 & 0,4483 & 0,5346 \\
\hline Varianto prioritetiškumas & $\mathbf{1}$ & $\mathbf{3}$ & $\mathbf{4}$ & $\mathbf{2}$ \\
\hline
\end{tabular}

Geriausia ir blogiausia alternatyva skaičiuojant abiem metodais sutapo. Antra ir trečia vietos keitèsi, bet jų skirtumas svyruoja dviejų šimtujų ribose. Todèl galima teigti, kad skaičiavimai yra korektiški. 


\subsection{Trečiojo skyriaus išvados}

1. Alternatyvu daugiakriterinio variantinio projektavimo metodas (Kaklauskas 1999; Kaklauskas et al. 2002 b; Zavadskas et al. 2003; Zavadskas et al. 2005; Banaitienè et al. 2008) pritaikytas nagrinejjant statybą ekonominio nuosmukio aplinkoje.

2. Sukurtos statybos projekto aplinkos veiksnių sistemos išsamiai apibūdina statybos ivvairiomis sąlygomis alternatyvas. Tai pritaikyta sprendžiant praktinius pavyzdžius: vertinant daugiabučių modernizavimo ir vilos parko ir statinių rekonstrukcijos projektų igyvendinimo skirtingoje ekonomineje aplinkoje rezultatus.

3. Sudarytos statybos projekto makro-, mezo ir mikroaplinkos sudetiniu dalių kompleksinès kriterijų duomenų bazès, kuriose statybos aplinkos sudètinių dalių alternatyvos kompleksiškai aprašomos kokybiniais ir kiekybiniais aspektais.

4. Sukurta rekomendacinè statybos ekonominio nuosmukio sąlygomis supančios aplinkos intelektinè sistema

5. Išsprendus praktini uždavini nustatytas statybos galimybių užsiimant daugiabučių namų modernizavimu arba kultūrinio paveldo objekto rekonstrukcija variantų naudingumo laipsnis ir prioritetiškumas. Geriausios sąlygos ir palankiausia aplinka buvo $2007 \mathrm{~m}$., kai abiejų projektų naudingumo laipsnis prilygo $100 \%$. 


\section{4}

\section{Rekomendacinè statybos ekonominio nuosmukio aplinkoje sistema}

Siekiant ivertinti statybos galimybes ekonominio nuosmukio aplinkoje ir numatyti i̇monès veiksmų plana, reikia kuo tiksliau apibūdinti tiek aplinka, tiek i̇monės pajègumą, tiek veikos rezultatus, o sprendimu paramos sistema privalo kuo geriau perteikti vartotojo reikalavimus. Pateikiami duomenys turi būti realūs ir nesunkiai atnaujinami. Tikslui pasiekti naudojamos internetinès technologijos, daugiakriterinio vertinimo metodai.

Remiantis atlikta sprendimu paramos sistemų analize ir siekiant nustatyti racionaliausią ir efektyviausią statybos projekto ekonominio nuosmukio aplinkoje igyvendinimo procesa, buvo sukurta rekomendacinè statybos ekonominio nuosmukio aplinkoje (SENA) sistema (4.1 pav.).

Kuriant SENA sistemą buvo taikoma plačiai naudojama naujausia programinè iranga ir technologijos:

1. Programuojant duomenų bazes naudojama vidinè Microsoft Access programinio paketo programinè kalba.

2. Internetiniuose puslapiuose, kuriuose nèra naudojami duomenys iš duomenų bazių ar atliekami ịvairūs skaičiavimai, naudojama HTML (Hypertext mark up language) programavimo kalba. 


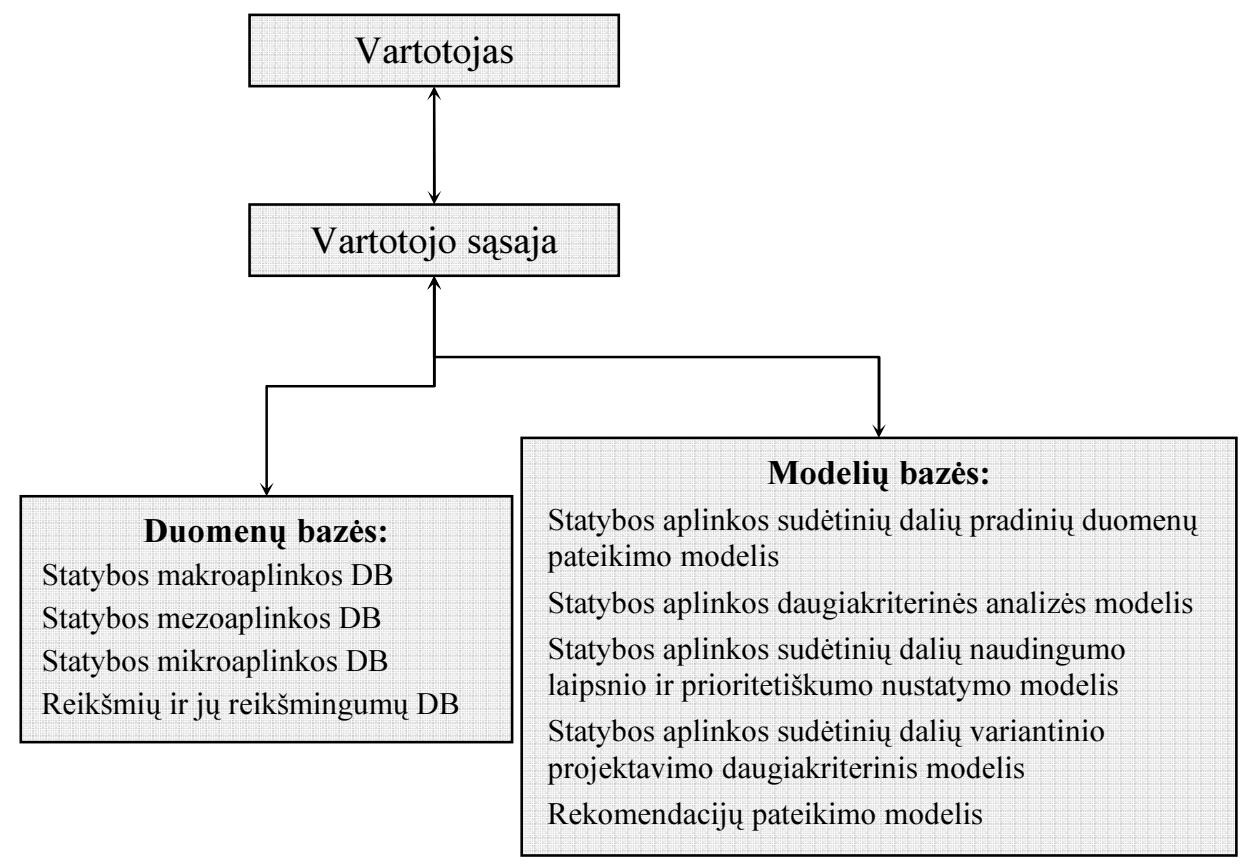

4.1 pav. SENA sistemos sudedamosios dalys

Fig. 4.1. Components of the CEER system

3. Internetiniuose puslapiuose, kuriuose naudojami duomenys iš duomenų bazių bei atliekami ìvairūs veiksmai su jais taikoma ASP (Active Server Pages) programavimo kalba.

4. Java Script ir ActiveX technologijos naudojamos projektuojant ir kuriant atskirus modulius bei vartotojo sąsają. Java Script programavimo kalba naudojama vykdomiesiems duomenims kurti, o ActiveX technologijos priemonemis sukurti komponentai naudojami ivvairioms programoms ir komponentams kurti.

Remiantis šiomis technologijomis SENA sistema buvo pritaikyta Windows $N T$ serverio platformai. Šis technologijų ir programinės įrangos derinys užtikrina lankstų sistemos darbą, palengvina vartotojo bendravimą su ja.

Kuriant SENA sistemą taikyti tokie principai ir metodai:

- kompleksinè analizė;

- funkcinè analizè;

- ivairių mokslų sąsaja;

- statybos projekto aplinkos daugiakriterinis variantu projektavimas;

- daugiakriterinè variantų analizè. 


\subsection{Rekomendacinès statybos ekonominio nuosmu- kio aplinkoje sistemos sudedamosios dalys}

Rekomendacinè statybos ekonominio nuosmukio aplinkoje sistema (RSENAS) sieja duomenų ir modelių bazes, kurias per vartotojo sąsają valdo sistemos vartotojas. Sistemą sudaro:

- duomenų bazès ir jų valdymo sistemos;

- modelių bazè ir jų valdymo sistemos;

- vartotojo sąaja.

Šios sudedamosios dalys sudarytos iš posistemių. Pavyzdžiui, modelių bazę sudaro statybos aplinkos sudedamujų dalių pradinių duomenų pateikimo modelis, naudingumo laipsnio ir prioritetiškumo nustatymo modelis, variantinio projektavimo daugiakriterinis modelis, rekomendacijų pateikimo modelis ir kt., o duomenų bazès sudarytos statybos aplinkos, projektų elementų ir kitų duomenų bazių lentelių.

RSENAS skirta naudotis internete. Todèl vartotojui ja paprasta naudotis ir nereikalauja specialaus pasirengimo. Sistemoje naudojama mišri vartotojo sąsaja - skirtingiems uždaviniams spręsti naudojami skirtingi sąsajos tipai.

\subsubsection{Duomenų bazès}

Statyba apima ivvairias suinteresuotas grupes (statytojus, projektuotojus, rangovus, gamintojus, tiekejjus, naudotojus ir kt.), kurių tikslai, galimybès bei požiūriai skiriasi. Todèl priimant sprendimus dažnai nesutampa šių suinteresuotų grupių viltys. Norint kuo išsamiau apibūdinti nagrinejjamas alternatyvas ir rasti sprendimą maksimaliai tenkinantị visų dalyvių tikslus, būtina aprepti didelius kiekius skirtingos informacijos, kuri apibūdina įvairius aspektus (ekonominius, teisinius, technologinius, sociokultūrinius, demografinius, geografinius, etinius, psichologinius ir kt.). RSENA sistemoje informacija, reikalinga sprendimams priimti, gali būti pateikta skaitmenine, tekstine, grafine ir kitokia forma. Pavyzdžiui, naudojant tekstinę informacijos pateikimo forma, pateikiamas kiekvieno kriterijaus aprašas (lentelèje, nuvedus pelès žymeklị ant kriterijaus pavadinimo, atsiveria hipertekstas su jo aprašu). Skaitine forma pateikiamos variantus apibūdinančių veiksnių reikšmès ir reikšmingumai.

Viena pagrindinių tokių sistemų funkcijų - rinkti ir kaupti žinias bei informaciją. Kaupimą ir saugojimą palengvina kompiuterinès technologijos. Tradiciniu atveju visa sprendimams priimti reikalinga informacija saugoma užrašuose, knygose, ivvairiuose leidiniuose ir pan. Duomenų bazèse informacija kaupiama ivairiais lygiais struktūrizuota forma. Tačiau skirtingose duomenų 
bazėse saugoma informacija skiriasi saugojimo standartais (skirtinga programinè iranga, skirtinga informacijos struktūra ir jos pateikimo formos bei pan.).

Šios problemos sprendimo būdas, taikytas RSENA sistemoje, yra jungtinių duomenų bazių kūrimas. Sistemoje duomenys saugomi vienoje duomenų bazèje, susidedančioje iš skirtingų lentelių bei nepriklausančioje nuo sprendimo prièmimo modelių bazès. Lentelès susietos ryšiais, kurie leidžia gauti visą reikalingą informaciją sprendimams priimti. RSENAS vartotojai, ivedantys duomenis ì duomenų bazę, pateikia visą reikiamą informaciją kompaktiškai, informacija nesikartoja.

Yra tokios fundamentinès duomenų bazių struktūros: hierarchinè, tinklinè ir reliacinè. RSENA sistemoje naudojama reliacinè duomenų bazių struktūra, kur informacija saugoma lentelių forma. RSENA sistema sudaryta iš:

- statybos makroaplinkos veiksnių DB;

- statybos mezoaplinkos veiksnių DB;

- statybos mikroaplinkos veiksnių DB;

- veiksnių reikšmių ir jų reikšmingumų DB.

Veiksnių ir jų reikšmių DB leidžia sprendimų prièmejjui gauti įvairią išsamią atskirų statybos elementų kiekybinę ir kokybinę informaciją. Duomenų ir modelių bazė leidžia šią informaciją lanksčiai analizuoti priimant sprendimą.

\subsubsection{Modelių bazè}

Statybos projekto igyvendinimo variantų efektyvumas vertinamas iš ekonominių, teisinių, technologinių, sociokultūrinių, demografinių, geografinių, etinių, psichologinių ir kitu pozicijų, todèl sistema susideda iš modelių, kurie sprendimų prièmejui padeda atlikti variantų kompleksinę analizę ir priimti tinkamą sprendimą.

Šioje sistemoje modelių bazę sudaro tokie modeliai:

- statybos aplinkos vertinimo pradiniu duomenu pateikimo modelis;

- statybos aplinkos daugiakriterinès analizès modelis;

- statybos aplinkos vertinimo naudingumo laipsnio ir prioritetiškumo nustatymo modelis;

- statybos aplinkos sudėtinių dalių variantinio projektavimo daugiakriterinis modelis;

- rekomendaciju pateikimo modelis.

Modelių bazès valdymo sistemas sudaro dirbtinis intelektas. Vieni sistemos modeliai veikia savarankiškai, o kiti teikia pradinę informaciją dar kitiems modeliams. Pavyzdžiui, statybos aplinkos variantų daugiakriterinès analizės skaičiavimo rezultatai tampa statybos aplinkos elementų naudingumo laipsnio ir prioritetiškumo nustatymo išeities duomenimis, o šiuos duo- 
menis naudoja statybos aplinkos elementų sudètinių dalių variantinio projektavimo modelis.

Modelių bazè teikia vartotojui pagalbą formuojant alternatyvas. Vartotojas gali analizuoti įvairius sprendimų variantus, koreguoti analizès apimtis, sutelkti dèmesi i prioritetinę informaciją. Modelių bazès funkcionalumas lemia visos sistemos funkcionalumą. Todèl RSENAS kūrimo metu tiek modelių bazès valdymo sistemos, tiek modelių struktūra buvo ne kartą keičiama ir tobulinama, tikrinama darbo su sistema metu gauta informacija, rezultatai lyginami su ekspertų skaičiavimo rezultatais.

Didesnis išnagrinètų alternatyvų skaičius leidžia tikètis racionalaus galutinio sprendimo. Statybos ekonominio nuosmukio aplinkoje sprendimų paramos sistema, remdamasi sukaupta informacija ir naudodama šiuos modelius, automatizuotai gali sudaryti tūkstančius elementų derinių.

Automatizuotai atliekama šių elementų derinių daugiakriterinè analizè, nustatomas naudingumo laipsnis ir prioritetai, išrenkami efektyviausi variantai. Aprašomos stipriosios ir silpnosios analizuojamų variantų savybès, kodèl ir kiek viena alternatyva yra priimtinesnè už kitą.

\subsection{Statybos ekonominio nuosmukio aplinkoje daugiakriterinè analizé ir variantinis projektavimas}

Norint pradèti darbą su RSENA sistema, reikia pasirinkti bet kurią kompiuteryje instaliuotą interneto naršyklę.

Pagrindinis sistemos langas yra suskirstytas į tris sritis (4.2 pav.):

- meniu juosta,

- antrašté,

- pagrindinè dalis.

Rekomendacinès statybos ekonominio nuosmukio aplinkoje sistemos meniu juostoje pateikiami šie punktai:

- pagrindinis puslapis;

- aplinkos alternatyvų aprašymas;

- aplinkos alternatyvų daugiakriterinis vertinimas;

- kompiuterizuotas efektyviausių alternatyvų išrinkimas;

- alternatyvų variantinis projektavimas;

- rekomendacijos vartotojui. 


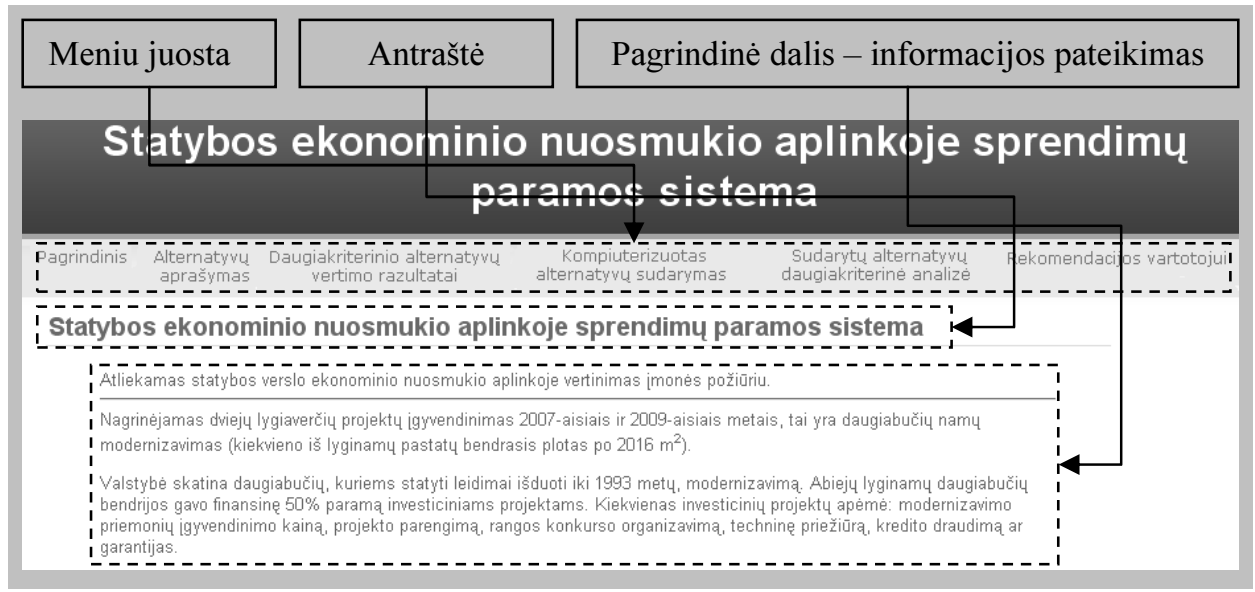

4.2 pav. Pagrindinis RSENAS langas

Fig. 4.2. The main window of RSCEER

Antrašteje pateikiamas sistemos pavadinimas, kuris nekinta.

Informacijos pateikimo lange pateikiama grafinis sistemos vaizdas, kuris priklauso nuo to, koks meniu juostos elementas aktyvuotas.

\subsubsection{Alternatyvų aprašymas}

Pasirinkus meniu juostoje punktą „Alternatyvų aprašymas“ pagrindiniame naršyklès lange pateikiama informacija apie nagrinejjamas alternatyvas: makro-, mezo-, ir mikroaplinkos variantus priskiriamus nagrinejjant daugiabučių namų modernizavimo arba paveldo objekto rekonstrukcijos projektus (4.3 pav.).

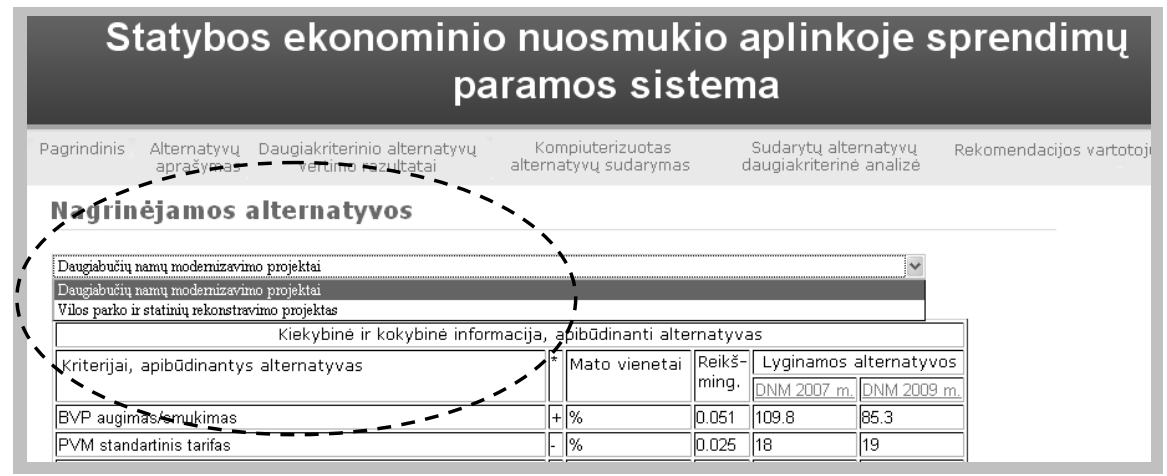

4.3 pav. Nagrinejjamų projektų alternatyvų langas

Fig. 4.3. The window of the project alternatives in question 
Pagrindinių duomenų matricoje pateikiama statybos aplinkos veiksnių sistema, nustatoma ar veiksnys yra maksimizuojantis ar minimizuojantis, pateikiami veiksnių mato vienetai ir svoriai. Pradinius veiksnių reikšmingumus pateikè autorè, remdamasi statybos imonès valdančiojo personalo apklausa. Skirtingi veiksnių reikšmingumai iprasmina, kiek vienas veiksnys svarbesnis už kitą. Pavyzdžiui, nagrinèjant daugiabučių namų modernizavimo projektus, nustatyta, kad darbo užmokesčio projekte reikšmingumas $q_{43}=0,128$, o medžiagų reikšmingumas $q_{44}=$ 0,422 , t. y. kompleksiškai vertinant darbo užmokesčio veiksnys yra mažiau reikšmingas už medžiagas.

Pele vedant per lentelès grafas, kuriose vardijami veiksniai, papildomuose languose atsiveria detalesnis kiekvieno jų apibūdinimas (4.4 pav.).

\begin{tabular}{|c|c|c|c|c|}
\hline Ateities lükesčił tenkinimas & + balai (0/10) & 0.044 & 9 & 6 \\
\hline Nerimas prarasti darbą & balai (0/10) & 0.057 & 3 & 8 \\
\hline 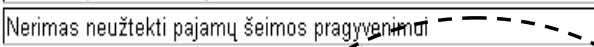 & balai (0/10) & 0.063 & 5 & 9 \\
\hline ,'Dèl galimo pajamy & $\mp$ salai (0/10) & 0.051 & 8 & 7 \\
\hline Nelegalūs darbiniai santykiai ' & - rezult. patikr. \% & 0.101 & 44.7 & 45.1 \\
\hline Kvalifikacijos kèlimo galimybés & + balai $(\mathbf{M} / 10)$ & 0.095 & 7 & 5 \\
\hline Konkurenty kiekis rinkoje & wnt. I & 0.076 & 342 & 470 \\
\hline Konkurenty aktyyumas ! & balai (d/10) & 0.095 & 7 & 9 \\
\hline Potencialiy kreditoriy kiekis ! & + unt, ', & 0.095 & 46 & 47 \\
\hline Kreditori galimybès & It b́alai (0/10) & 0.127 & 9 & 5 \\
\hline Darbuotojy etikos kodekso laikymasis & + balai $(0 / 10)$ & 0.057 & 6 & 7 \\
\hline
\end{tabular}

4.4 pav. Veiksnį apibūdinanti papildoma informacija

Fig. 4.4. Additional information for one factor

\subsubsection{Statybos ekonominio nuosmukio aplinkoje sudètiniu dalių daugiakriterinè analizè}

Pasirinkus meniu punktą „Alternatyvų daugiakriteriné analizé“ atliekama dviejų rūšių statybos projektų igyvendinimo aplinkos sudedamujjų dalių (daugiabučių namų modernizavimo ir paveldo objekto rekonstrukcijos) daugiakriterinè analizè.

Pele pasirinkus bet kurị iš šių punktų, RSENA sistema paleidžia statybos aplinkos sudedamujų dalių pradinių duomenų pateikimo daugiakriterinès analizès modulius konkrečiam aplinkos elementui. Kaip pavyzdi panagrinèkime atliekamą daugiabučių namų modernizavimo daugiakriterinę analizę.

Ši analizè atliekama dviem etapais:

- pirmajame etape sudaroma įvertinta normalizuota sprendimų prièmimo matrica; 
- antrajame etape atliekama variantų daugiakriterinè analizè, kurios metu nustatomas alternatyvus prioritetiškumas ir naudingumo laipsnis.

4.5 paveiksle pateikiamas projektų igyvendinimo variantų normalizuotos sprendimų prièmimo matricos fragmentas.

\section{Daugiakriterinio alternatyvų vertinimo razultatai}

Daugiabučị namu modemizavimo projektai

\begin{tabular}{|c|c|c|c|c|c|}
\hline \multicolumn{6}{|c|}{ Kiekybinè ir kokybinè informacija, apibūdinanti alternatyvas } \\
\hline \multirow[t]{2}{*}{ Kriterijai, apibūdinantys alternatyvas } & \multirow[t]{2}{*}{ * } & \multirow[t]{2}{*}{ Mato vienetai } & \multirow{2}{*}{$\begin{array}{l}\text { Reikš- } \\
\text { ming. }\end{array}$} & \multicolumn{2}{|c|}{ Lyginamos alternatyvos } \\
\hline & & & & DNM $2007 \mathrm{~m}$. & DNM $2009 \mathrm{~m}$ \\
\hline BVP augimas/smukimas & + & $\%$ & 0.051 & $\begin{array}{c}0.0287 \\
\text { AVG MIN }\end{array}$ & $\begin{array}{c}0.0223 \\
\text { AVG MIN }\end{array}$ \\
\hline PVM standartinis tarifas & & $\%$ & 0.025 & $\begin{array}{c}0.0122 \\
\text { AVG MIN }\end{array}$ & $\begin{array}{c}0.0128 \\
\text { AVG MIN }\end{array}$ \\
\hline Palūkany normos & & $\%$ & 0.038 & $\begin{array}{c}0.0153 \\
\mathrm{AVG} \text { MIN } \\
\end{array}$ & $\begin{array}{c}0.0227 \\
\mathrm{AVG} \mathrm{M} \| \mathrm{N} \\
\end{array}$ \\
\hline Mokestinès lengvatos mokant kreditą & + & balai $(0 / 10)$ & 0.038 & $\begin{array}{c}0.0234 \\
\mathrm{AVG} \mathrm{M \| N} \\
\end{array}$ & $\begin{array}{c}0.0146 \\
\text { AVG MIN }\end{array}$ \\
\hline Pasaulinis konkurencingumo indeksas & & vieta & 0.038 & $\begin{array}{c}0.0176 \\
\text { AVG MIN }\end{array}$ & $\begin{array}{c}0.0204 \\
\text { AVG M\|N }\end{array}$ \\
\hline Vartotoju pasitikejjimo rodiklis & + & $\%$ & 0.032 & $\begin{array}{c}0.0213 \\
\text { AVG MIN }\end{array}$ & $\begin{array}{c}0.0107 \\
\text { AVG M\|N }\end{array}$ \\
\hline Vidutinis menesinis bruto darbo užmokestis & & $\mathrm{Lt}$ & 0.135 & $\begin{array}{c}0.0631 \\
\text { AVG M\|N }\end{array}$ & $\begin{array}{c}0.0719 \\
\text { AVG MIN }\end{array}$ \\
\hline
\end{tabular}

4.5 pav. Daugiabučių namų modernizavimo projektų igyvendinimo variantų normalizuotos sprendimu priemimo matricos fragmentas

Fig. 4.5. A fragment of the normalised decision-making matrix with variants of refurbishment projects for apartment buildings

Sprendimų matricoje taip pat pateikta veiksnių sistema, veiksnių matavimo vienetai, reikšmingumai ir reikšmès, išsamiai apibūdinantys nagrinejjamas statybos projektu igyvendinimo aplinkos sudètinių dalių alternatyvas. Vartotojas gali peržiūrèti visų veiksnių aprašymus.

Lentelès apačioje sistema pateikia antrojo skaičiavimų etapo rezultatus, t. y. daugiakriterinès analizès prioritetiškumo ir naudingumo laipsnio nustatymo modeliai, remdamiesi duomenų bazejje esančiais variantų pradiniais duomenimis, atlieka daugiakriterinę analizę (4.6 pav.). 


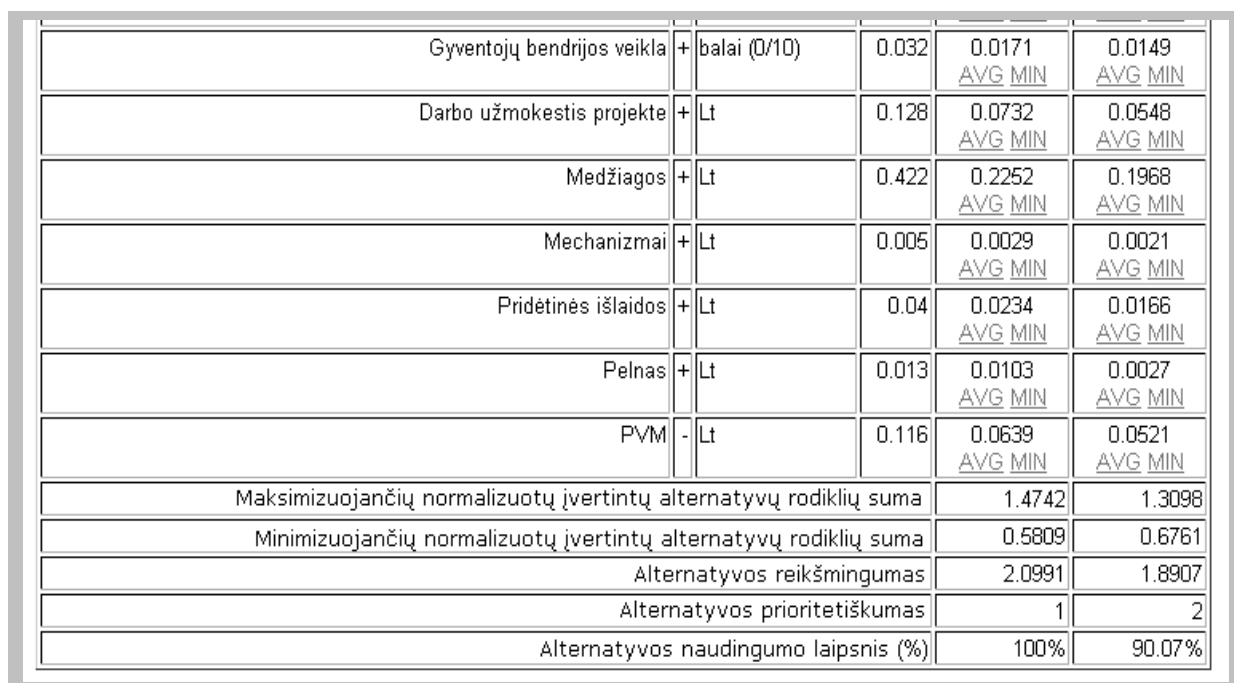

4.6 pav. Sistemos atliekamos daugiakriterinès analizès fragmentas

Fig. 4.6. A fragment of the multiple criteria analysis in the system

Pavyzdžiui, skaičiuojant buvo nustatytas daugiabučiu namų modernizavimo projektu igyvendinimo, esant skirtingai makro-, mezo- ir mikroaplinkai, variantų naudingumo laipsnis ir prioritetiškumas. Iš gautų rezultatų matyti, kad geresnių rezultatų imonè gali tikètis pirmuoju variantu. Jo naudingumo laipsnis yra $N_{1}=$ $100 \%$. Antrasis variantas lenteleje yra prastesnis: $N_{2}=90,07 \%$.

Analogiškai atliekama ir paveldo objekto rekonstravimo projekto igyvendinimo skirtingomis sąlygomis daugiakriterinè analizè. Papildant duomenų bazes, analogiškai gali būti vykdomi ir kitų sprendimų (daugiabučių modernizavimo investuotojo požiūriu (F priedas) ir pan.) variantų daugiakriterinè analizè.

\subsubsection{Statybos ekonominio nuosmukio aplinkoje variantinis projektavimas}

Atlikus automatizuotą statybos ekonominio nuosmukio aplinkoje daugiakriterinę analizę, automatizuotu būdu lyginami alternatyvų variantai. Šiam tikslui taikomas alternatyvų daugiakriterinio variantinio projektavimo metodas.

Pasirinkus meniu juostoje punktą „Kompiuterizuotas alternatyvų sudarymas“ pagrindiniame lange išvedami visi statybos aplinkos elementai (daugiabučių namų modernizavimo projektu bei kultūros paveldo objekto rekonstrukcijos projekto igyvendinimo rezultatai). Sistemos vartotojas gali pasirinkti norimą alternatyvų skaičių ir pačias alternatyvas (4.7 pav.). 


\section{Kompiuterizuotas alternatyvų sudarymas}

\begin{tabular}{|c|c|c|c|c|c|c|c|c|c|c|c|}
\hline \multicolumn{12}{|c|}{ Kiekybine ir kokybiné informacija, apibūdinanti alternatyvas } \\
\hline \multirow{2}{*}{$\begin{array}{l}\text { Kriterijai, apibūdinantys } \\
\text { alternatyvas }\end{array}$} & \multirow[t]{2}{*}{ * } & \multirow{2}{*}{$\begin{array}{l}\text { Mato } \\
\text { vienetai }\end{array}$} & \multirow{2}{*}{$\begin{array}{l}\text { Reikš- } \\
\text { min- } \\
\text { gumai }\end{array}$} & \multicolumn{8}{|c|}{ Lyginamos alternatyvos } \\
\hline & & & & 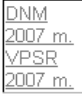 & $\begin{array}{l}\frac{\mathrm{DNM}}{2007} \mathrm{~m} \\
\mathrm{VPSR} \\
2008 \mathrm{~m} . \\
\end{array}$ & $\frac{D N M}{2007 m}$. & $\frac{\text { DNM }}{2007 \mathrm{~m}}$. & \begin{tabular}{|l} 
DNM \\
$\frac{2009}{\mathrm{~m}} \mathrm{~m}$. \\
$\mathrm{VPSR}$ \\
$2007 \mathrm{~m}$. \\
\end{tabular} & 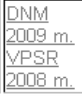 & 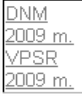 & $\begin{array}{l}\frac{D N M}{2009} \mathrm{~m} \\
\text { PPSR } \\
2010 \mathrm{~m} . \\
\end{array}$ \\
\hline BVP augimas/smukimas & + & $\%$ & 0.051 & 109.8 & 109.8 & 109.8 & 109.8 & 85.3 & 85.3 & 85.3 & 85.3 \\
\hline $\begin{array}{l}\text { Mokestinés lengvatos } \\
\text { mokant kreditą }\end{array}$ & + & balai $(0 / 10)$ & 0.038 & 8 & 8 & 8 & 8 & 5 & 5 & 5 & 5 \\
\hline $\begin{array}{l}\text { Pasaulinis konkurencingumo } \\
\text { indeksas }\end{array}$ & - & vieta & 0.038 & 38 & 38 & 38 & 38 & 44 & 44 & 44 & 44 \\
\hline Vartotoju pasitikèjimo rodiklis & + & $\%$ & 0.032 & 104 & 104 & 104 & 104 & 52 & 52 & 52 & 52 \\
\hline Nedarbo lygis & - & $\%$ & 0.063 & 4.3 & 4.3 & 4.3 & 4.3 & 17.6 & 17.6 & 17.6 & 17.6 \\
\hline $\begin{array}{l}\text { Korupcijos suvokimo } \\
\text { indeksas }\end{array}$ & + & balai $(0 / 10)$ & 0.025 & 4.8 & 4.8 & 4.8 & 4.8 & 4.9 & 4.9 & 4.9 & 4.9 \\
\hline
\end{tabular}

4.7 pav. Statybos aplinkos sudedamujų dalių variantų parinkimo langas

Fig. 4.7. The window with component options of the environment of construction

Taip atrenkamos geriausios alternatyvos. RSENA sistema, naudodamasi daugiakriterinès analizès ir naudingumo laipsnio nustatymo modeliais bei remdamasi iki tol atliktais skaičiavimais, nustato visu statybos projektų igyvendinimo aplinkos sudètinių dalių variantų prioritetiškumus ir naudingumo laipsnius. Tada atliekamas variantinis projektavimas ir iš atskirų projektų sudètinių dalių sudaromas geriausiai suinteresuotų grupių poreikius atitinkantis statybos projektų igyvendinimo aplinkos derinys.

\section{Sudarytụ alternatyvụ daugiakriterinẻ analizẻ}

\begin{tabular}{|c|c|c|c|c|c|c|c|c|c|c|c|}
\hline \multicolumn{12}{|c|}{ Kiekybine ir kokybine jnformacija, apibūdinanti alternatyvas } \\
\hline \multirow{2}{*}{\begin{tabular}{|l|} 
Kriterijai, \\
apibūdinantys \\
alternatyvas
\end{tabular}} & \multirow{2}{*}{\multicolumn{2}{|c|}{$\begin{array}{l}\text { Mato } \\
\text { vienetai }\end{array}$}} & \multirow{2}{*}{$\begin{array}{l}\text { Reik } \mathbf{k}- \\
\text { mirt- } \\
\text { gumai } \\
\mathbf{1}\end{array}$} & \multicolumn{8}{|c|}{ Lyginamos alternatyvos } \\
\hline & & & & 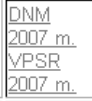 & 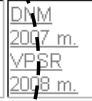 & $\begin{array}{l}\frac{\text { DNM }}{2007 \text { m. }} \\
\frac{20 S R}{2009 m .} \\
\end{array}$ & $\begin{array}{l}\frac{D N M}{2007} \mathrm{~m} . \\
\frac{20 \mathrm{PR}}{2010 \mathrm{~m}} . \\
\end{array}$ & $\begin{array}{l}\frac{\text { DNM }}{2009 m} \text { m. } \\
\frac{\text { VPSR }}{2007 m .} \\
\end{array}$ & 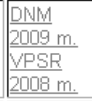 & $\begin{array}{l}\frac{D N M}{2009} \mathrm{~m} . \\
\frac{\mathrm{VPSR}}{2009 \mathrm{~m} .} \\
\end{array}$ & $\begin{array}{l}\frac{\text { DNM }}{2009 \text { m. }} \\
\frac{20 S R}{2010 ~ m . ~} \\
\end{array}$ \\
\hline BVP augimas/smukimas & & $\%$ & 0.051 & 0.007176 & 0.007176 & 0.007176 & 0.007176 & 0.005574 & 0.005574 & 0.005574 & 0.005574 \\
\hline PVM standartinis tarifas & - & $\%$ & $0.02 \mathrm{~A}$ & 0.003041 & d'.003041 & 0.003041 & 0.003041 & 0.003209 & 0.003209 & 0.003209 & 0.003209 \\
\hline Palūkany normos & H & $\%$ & 0.038 & 8003835 & 0.003835 & 0.003835 & 0.003835 & 0.005665 & 0.005665 & 0.005665 & 0.005665 \\
\hline $\begin{array}{l}\text { Mokestines lengratos } \\
\text { mokant kreditą }\end{array}$ & + & balai $(0 / 10)$ & 0.038 & 0.005846 & 0.005846 & 0.005846 & 0.005846 & 0.003654 & 0.003654 & 0.003654 & 0.003654 \\
\hline $\begin{array}{l}\text { Pasaulinis } \\
\text { konkurencingumo } \\
\text { indeksas }\end{array}$ & & vieta & 0.038 & 0.004402 & 0.004402 & 0.004402 & 0.004402 & 0.005098 & 0.005098 & 0.005098 & 0.005098 \\
\hline $\begin{array}{l}\text { Vartotoju pasitikejimo } \\
\text { rodiklis }\end{array}$ & & $\%$ & 0.032 & 0.005333 & 0.005333 & 0.005333 & 0.005333 & 0.002667 & 0.002667 & 0.002667 & 0.002667 \\
\hline
\end{tabular}

4.8 pav. Geriausias statybos aplinkos derinys

Fig. 4.8. The best combination of the environment of construction 
Pavyzdžiui, atlikus daugiavariantị projektavimą nustatyta, kad verslininkui užsiimti statyba palankiausia aplinka aprašyta $2007 \mathrm{~m}$. duomenimis (4.8 pav.).

Nepaisant to, kad $2007 \mathrm{~m}$. statybos dar nebuvo pasiekusios bumo (daugiausia statybos darbai buvo pabrangę $2008 \mathrm{~m}$. viduryje), sistema išskyrè šiuos metus kaip palankiausius statybos projektui igyvendinti (4.9 pav.).

\begin{tabular}{|l|l|l|l|l|l|l|l|l||}
\hline \hline & 0.605 & 0.5988 & 0.5867 & 0.6 & 0.5639 & 0.5577 & 0.5456 & 0.5588 \\
\hline \hline & 0.1853 & 0.1918 & 0.198 & 0.196 & 0.2091 & 0.2156 & 0.2218 & 0.2198 \\
\hline $\mathbf{1}$ & 0.8089 & 0.7992 & 0.7841 & 0.8005 & 0.755 & 0.7462 & 0.7317 & 0.7486 \\
\hline $\mathbf{1}$ & $\mathbf{1}$ & $\mathbf{1}$ & 2 & 5 & 7 & 8 & 6 \\
\hline \\
\hline
\end{tabular}

4.9 pav. Geriausias statybos aplinkos derinys, kurio prioritetiškumas - $100 \%$ Fig. 4.9. The best combination of the environment of construction with a $100 \%$ priority

Tie patys metai kaip geriausia statybos projekto aplinka išskirti ir nagrinejjant dvieju paveldo objektu projektus: buvo palygintas tas pats Vilos parko ir statinių rekonstravimo bei Pakruojo dvaro sodybos restauravimo projektas (E priedas).

\subsubsection{Statybos ekonominio nuosmukio aplinkoje rekomendaciju pateikimas}

Rekomendacinè statybos ekonominio nuosmukio aplinkoje sistema (4.10 pav.) igyvendinant $2007 \mathrm{~m}$. daugiabučių namų modernizavimo projektą teikia tokias rekomendacijas:

- Reikšmingiausias (daugiausiai itakos rezultatui turèjęs) kriterijus yra darbuotojų iniciatyvumas.

- Pagal atliktus skaičiavimus, skyrus demesio darbuotojų iniciatyvumui skatinti, beveik 2,7\% pagerètu imonès veiklos rezultatai (4.11 pav.).

Antroje vietoje atsidūrè statybos sąnaudų kainų indeksai, o trečias pagal itakos svarumą - darbuotojų lojalumo rodiklis. 


\section{Rekomendacijos vartotojui}

Daugiabučiu namų modemizavimo projektai

\begin{tabular}{|c|c|c|c|c|c|}
\hline \multicolumn{6}{|c|}{ Kiekybine ir kokybine informacija, apibūdinanti alternatyvas } \\
\hline \multirow[t]{2}{*}{ Kriterijai, apibūdinantys alternatyvas } & \multirow[t]{2}{*}{ 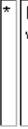 } & \multirow[t]{2}{*}{$\begin{array}{l}\text { Mato } \\
\text { vienetai }\end{array}$} & \multirow[t]{2}{*}{$\begin{array}{l}\text { Reikš- } \\
\text { ming. }\end{array}$} & \multicolumn{2}{|c|}{$\begin{array}{l}\text { - Lyginamos alternatyvos } \\
\text { - Galimas analizuojamo kriterijaus tobulinimas \% } \\
\text { - Galimas vertes padidejimas \%, } \\
\text { patobulinus nagrinejamą kriterijų }\end{array}$} \\
\hline & & & & DNM $2007 \mathrm{~m}$. & DNM $2009 \mathrm{~m}$. \\
\hline BVP augimas/smukimas & + & $\%$ & 0.051 & $\begin{array}{l}109.8 \\
(0 \%) \\
(0 \%)\end{array}$ & $\begin{array}{l}85.3 \\
(28.72 \%) \\
(0.3625 \%)\end{array}$ \\
\hline PVM standartinis tarifas & & $\%$ & 0.025 & $\begin{array}{l}18 \\
(0 \%) \\
m n<x\end{array}$ & $\begin{array}{l}19 \\
(5.26 \%)\end{array}$ \\
\hline
\end{tabular}

4.10 pav. Rekomendacijų pateikiamų vartotojui fragmentas

Fig. 4.10. A fragment of the recommendations for users

Nagrinejjant $2009 \mathrm{~m}$. projektą sistema išskyrè statybos pasitikejjimo rodiklio pablogèjimą (4.11 pav.), pasikeitus šiam kriterijui i geresniają pusę, galima laukti $10,6 \%$ geresniu projekto igyvendinimo rezultatų. Antroje vietoje išskyrè kreditorių galimybes, o trečia -medžiagų dalis.

3 kriterijai labiausiai ịtakojantys projektą

\begin{tabular}{|c|c|c|c|}
\hline \multicolumn{4}{|c|}{ DNM $2007 \mathrm{~m}}$. \\
\hline Vieta & $\begin{array}{l}\text { Alternatyvu } \\
\text { kriterijai }\end{array}$ & $\begin{array}{l}\text { Galimas kriterijaus } \\
\text { tobulinimas } \%\end{array}$ & $\begin{array}{l}\text { Galimas vertès padidejjimas } \%_{,} \\
\text {patobulinus nagrinejjamą kriteriju }\end{array}$ \\
\hline & \begin{tabular}{|l} 
Darbuotojy \\
iniciatyvumas
\end{tabular} & $100 \%$ & $2.6726 \%$ \\
\hline 2 & $2 \begin{array}{l}\text { Statybos sanaudy } \\
\text { kainy indeksai }\end{array}$ & $24.33 \%$ & $1.4871 \%$ \\
\hline 3 & 3 Darbuotojy lojalumas & $100 \%$ & $1.2621 \%$ \\
\hline
\end{tabular}

\begin{tabular}{|r|l|l|l||}
\hline \multicolumn{2}{|c|}{ DNM 2009 m. } \\
\hline Vieta & $\begin{array}{l}\text { Alternatyvu } \\
\text { kriterijai }\end{array}$ & $\begin{array}{l}\text { Galimas kriterijaus } \\
\text { tobulinimas\% }\end{array}$ & $\begin{array}{l}\text { Galimas vertés padidéjimas \%, } \\
\text { patobulinus nagrinejamą kriteriju }\end{array}$ \\
\hline \hline 1 & $\begin{array}{l}\text { Statybos pasitikejimo } \\
\text { rodiklis }\end{array}$ & $377.27 \%$ & $10.6432 \%$ \\
\hline \hline 2 & Kreditoriu galimybès & $80 \%$ & $2.5142 \%$ \\
\hline \hline 3 & Medžiagos & $14.4 \%$ & $1.5034 \%$ \\
\hline \hline
\end{tabular}

4.11 pav. Svarbiausių rekomendacijų pateikimas RSENA sistema

Fig. 4.11. Display of the key recommendations in the RCEER system

Buvo palyginti tie patys daugiabučių modernizavimo projektai (jie sistemoje ivvardinti kaip šešiaaukščių namų modernizavimo projektai) ir dviejų devynaukščių namų modernizavimo projektai, vykdyti 2008 ir $2010 \mathrm{~m}$. (F priedas), tiek ịmonès, tiek investuotojo požiūriu. Pagal sistemoje pateiktus duomenis verslui palankiausias 2007 ir 2010 metų verslo aplinkos derinys.

Lyginant sistemoje šešiaaukščių namų modernizavimą (4.12 pav.), 2007 m. kaip reikšmingiausias išskirtas darbuotojų iniciatyvumas $(2,7 \%)$, o 
2009 m. - statybos pasitikejjimo rodiklis (10,7\%). Lyginant devynaukščiu namų modernizavimo projektus $2008 \mathrm{~m}$. išsiskiria vidutinio mènesinio bruto darbo užmokesčio statyboje kriterijus (galima reikšmès korekcija iki 1,9\%), o 2010 m. - pridètinių išlaidų dalis (koregavimas būtų iki 8,4 \%).

\begin{tabular}{|c|c|c|c|}
\hline \multicolumn{4}{|c|}{$2007 \mathrm{~m}$. } \\
\hline Vieta & $\begin{array}{l}\text { Alternatyvu } \\
\text { kriterijai }\end{array}$ & $\begin{array}{l}\text { Galimas kriterijaus } \\
\text { tobulinimas } \%\end{array}$ & $\begin{array}{l}\text { Galimas vertès padidejimas } \%, \\
\text { patobulinus nagrinejamą kriteriju }\end{array}$ \\
\hline 1 & $\begin{array}{l}\text { Darbuotoju } \\
\text { iniciatyvumas }\end{array}$ & $100 \%$ & $2.6906 \%$ \\
\hline 2 & $\begin{array}{l}\text { Statybos sąnaudy } \\
\text { kainy indeksai }\end{array}$ & $24.33 \%$ & $1.4971 \%$ \\
\hline 3 & Darbuotoju lojalumas & $100 \%$ & $1.2706 \%$ \\
\hline \multicolumn{4}{|c|}{$2009 \mathrm{~m}}$. \\
\hline Vieta & $\begin{array}{l}\text { Alternatyvu } \\
\text { kriterijai }\end{array}$ & $\begin{array}{l}\text { Galimas kriterijaus } \\
\text { tobulinimas \% }\end{array}$ & $\begin{array}{l}\text { Galimas vertès padidejimas } \%, \\
\text { patobulinus nagrinejamą kriteriju }\end{array}$ \\
\hline 1 & $\begin{array}{l}\text { Statybos pasitikejimo } \\
\text { rodiklis }\end{array}$ & $377.27 \%$ & $10.7148 \%$ \\
\hline 2 & Kreditoriy galimybès & $80 \%$ & $2.5311 \%$ \\
\hline 3 & Medžiagos & $14.4 \%$ & $1.5135 \%$ \\
\hline
\end{tabular}

4.12 pav. Svarbiausių rekomendacijų pateikimas RSENA sistema (2)

Fig. 4.12. Display of the key recommendations in the RCEER system (2)

Sistemos pateikiamos rekomendacijos yra reikšmingos ir verslininkui (padeda išskirti reikšmingiausius kriterijus ir planuoti savo veikla), ir investuotojui (padeda nustatyti, kokiomis aplinkybemis geriau rinktis investavimo laika).

RSENA sistemos darbe naudojama įvairi informacija. Vartotojai, prisiregistravę prie sistemos, gali nesunkiai papildyti, keisti kriterijų reikšmes, atsižvelgdami į savo prioritetus ar remdamiesi ekspertų apklausos rezultatais. Sudarant galimus projektų igyvendinimo variantus, gali būti ịvedama įvairių apribojimų. Kiekvienas sistemos vartotojas savo reikmèms atlieka tam tikrus skaičiavimus, kartu suteikdamas informaciją kitiems vartotojams.

RSENA sistema yra plati ir gali būti taikoma ịvairiems teoriniams bei praktiniams uždaviniams spręsti, todèl šios sistemos teikiamas galimybes galima naudoti statybos valdyme, ivvairiose mokymo institucijose, paslaugu imonėse, konsultuojant, atliekant ekspertinius vertinimus ir panašiai.

\subsection{Ketvirtojo skyriaus išvados}

1. Sukurta originali rekomendacinè statybos ekonominio nuosmukio aplinkoje sistema, sudaranti sąlygas kompleksiškai analizuoti statybos procesa, sudètines jo dalis, suinteresuotu grupių poreikius bei makro-, mezo- ir mikroaplinką. 
2. Sistemoje yra grižtamasis ryšys, todèl atsiranda nuolatinis poreikis tobulinti ir pildyti naujais duomenimis esamą sistemą.

3. Sistema universali ir gali būti taikoma ivvairiems teoriniams bei praktiniams uždaviniams spręsti. Šios sistemos teikiamomis galimybėmis gali naudotis įvairios suinteresuotos grupès (statytojai, rangovai, imonių vadovai, investuotojai ir kt.).

4. Sistema teikia rekomendacijuc vartotojui. Naudojantis sukurta sistema nustatyta, kad statybai palankiausia aplinka buvo 2007 m., nors daugelio statybos sudedamuju dalių kainos dar nebuvo maksimaliai pakilusios. Dalis reikšmingų kriterijų nepasiduoda verslininko tiesioginiam poveikiui, bet kai kuriuos jis gali nesunkiai keisti, pavyzdžiui, darbuotojų iniciatyvumą ir lojalumą. 


\section{Bendrosios išvados}

1. Pasaulinių tyrimų analizè parodè, kad daugelis intelektinių sistemų tiria bendros ekonominès krizès itaką finansų ar bankinių sistemų srityje. Bendro mikro-, mezo- ir makroaplinkos veiksnių poveikio statybos sektoriui ir verslo galimybėms ekonominio nuosmukio aplinkoje netyrinèta.

2. Remiantis sudètingų sistemų teorija ir daugiakriterinès analizès modeliais, autorès sukurtas originalus statybos ekonominio nuosmukio aplinkoje modelis. Jis leidžia vartotojui detaliai apibūdinti statybos aplinką skirtingais lygiais ir ivertinti jos poveiki veiklos rezultatams.

3. Sukurta kriterijų sistema, apibūdinanti statybos esant bendriems ekonomikos sunkumams aplinka. Kriterijų skaičius svyruoja nuo 47 iki 52, ir gali būti koreguojamas pagal vartojo poreikius. Sprendžiant konkrečius uždavinius (daugiabučių namų modernizavimo ir vilos parko ir statinių rekonstrukcijos) įrodytas SENA modelio tinkamumas.

4. SENA modelis leidžia nustatyti statybos aplinkos variantų naudingumo laipsni (pvz., $N_{D N M}-100 \%$ ir 90,07\%) ir prioritetiškumą (pvz., $P_{V P S R}-1>2>4>3$ ), kompleksiškai ịvertinus nagrinejjamų alternatyvų teigiamas bei neigiamas savybes. 
5. Sukurta rekomendacinė statybos ekonominio nuosmukio aplinkoje daugiakriterine sistema sudaro sąlygas kompleksiškai analizuoti statybos projektu igyvendinimo procesa, sudetines jo dalis, jame dalyvaujančias suinteresuotas grupes ir veikiančią išorinę aplinką. Ši sistema yra universali ir gali būti taikoma ivvairiems statybos teoriniams bei praktiniams uždaviniams spręsti, ja gali naudotis ịvairios suinteresuotos grupès: investuotojai, rangovai, tiekejjai, projektuotojai, naudotojai, pritaikydami savo tikslams.

6. Sukurta statybos aplinkos kriterijų sistema leidžia analizuoti bei vertinti statybos ir rekonstrukcijos projektų igyvendinimo galimybes. Remiantis sukurta statybos šakos makro-, mezo- ir mikroaplinkos kompleksine žinių duomenų baze, sistema sudaro sąlygas kompleksiškai analizuoti aplinką kiekybine bei kokybine formomis.

7. SENA sistema teikia rekomendacijas suinteresuotoms grupems, pavyzdžiui, statybos įmonei (tobulinant veikla) arba investuotojui (apsisprendžiant dèl investavimo laiko bei sąlygų). 


\section{Literatūra ir šaltiniai}

AB „ŽIA valda“ [interaktyvus]. 2008. [žiūrèta 2008 m. gegužès 23 d.] Prieiga per internetą: <http://www.ziavalda.lt/index.php?id=456>

Alam, P., Booth, D., Lee, K., Thordarson, T. 2000. The use of fuzzy clustering algorithm and self-organizing neural networks for identifying potentially failing banks: an experimental study. Expert Systems with Applications 18(3): 185-199. ISSN: 09574174.

Antuchevičienè, J. 2005. Alternatyvų vertinimo būdai TOPSIS metodu, esant neapibrèžtumui. Ükio technologinis ir ekonominis vystymas 11(4): 242-247. ISSN 1392-8619.

Arciszewski, T. 2006. Civil Engineering Crisis. Leadership and Management in Engineering 6(1): 26-30.

Baltic property market report, Q1 [interaktyvus]. 2009. Prieiga per interneta: $<$ http://www.resolution.lt/repository/research/Baltijos\%20saliu\%20nekilnojamojo\%20tu rto\%20rinkos\%20apzvalga\%202009.pdf>

Banaitiene, N.; Banaitis, A.; Kaklauskas, A.; Zavadskas, E. K. 2008. Evaluating the life cycle of a building: a multivariate and multiple criteria approach. Omega: the international journal of management science 36(3): 429-441. Oxford: Elsevier. ISSN 0305-0483.

Bennett, R. 2005. Marketing policies of companies in a cyclical sector: an empirical study of the construction industry in the United Kingdom. Journal of Business \& Industrial Marketing 20(3): 118-126. ISSN: 0885-8624. 
Bernatonytè, D., Vilkè, R., Keizerienė, E. 2009. Ekonominès krizès poveikio Lietuvos smulkiu ir vidutiniu imoniu socialinei atsakomybei kryptys. Ekonomika ir vadyba 14: 229-236. ISSN 1822-6515.

By D. Brown Management [interaktyvus]. 2008. Five Strategies to Keep Your Construction Business Profitable During An Economic Slowdown [žiūrèta 2008 m. liepos 22 d.]. Prieiga per internetą: <http://www.acppubs.com/article/CA6580360.html >

Black, A. 2004. The quest for sustainable, healthy communities [interaktyvus]. Paper presented to Effective Sustainability Education Conference, NSW Council on Environmental Education, UNSW, Sydney, Feb 18-20. [žiūrèta 2008 m. balandžio 18 d.]. Prieiga per interneta: $\quad<$ http://www.environment.nsw.gov.au/resources/cee/ alanblack.pdf $>$

Blackman, S. 2009. Education key to construction skills crisis [interaktyvus]. [žiūrèta 2009 m. lapkričio 14d.] Prieiga per interneta: <http://www.constructionweekonline. com/article-5525-education_key_to_construction_skills_crisis/>

Bosch, G. 2007. Konzeptstudie zur Entwicklung eines Leitbildes Bauwirtschaft der Bundesrepublik Deutschland [interaktyvus]. [žiūrèta $2007 \mathrm{~m}$. gruodžio 6 d.]. Prieiga per internetą: <http://www.bmvbs.de/Anlage/original_1018368/Konzeptstudie-zur-Entwick lung-eines-Leitbildes-Bauwirtschaft.pdf $>$

Buika, M. 2008. Solidarumo uždaviniai finansų krizės akivaizdoje. XXI Amžius. Krikščioniškos minties, kultūros ir visuomenès laikraštis [interaktyvus], 93(1686), [žiūrèta $2008 \mathrm{~m}$. gruodžio $10 \mathrm{~d}$.]. Prieiga per interneta: <http://www.xxiamzius.lt /numeriai/2008/12/10/index.html $>$

Canbas, S., Cabuk, A., Kilic, S. B. 2005. Prediction of commercial bank failure via multivariate statistical analysis of financial structures: the Turkish case. European Journal of Operational Research 166: 528-46. ISSN: 0377-2217.

Celik, A. E., Karatepe, Y. 2007. Evaluating and forecasting banking crises through neural network models: an application for Turkish banking sector. Expert Systems with Applications: An International Journal 33(4): 809-815. ISSN: 0957-4174.

Chen, W. H., Shih, J. Y. 2006. A study of Taiwan's issuer credit rating systems using support vector machines. Expert Systems with Applications 30, 427-435. ISSN: 09574174.

Cnuddle, M. 1991. Lack of quality in construction - Economic losses. Proc., European Symposium on Management, Quality and Economics in Housing and Other Building Sectors, 508-515.

Common Actions for Growth and Employment: The Community Lisbon Programme [interaktyvus]. 2005 [žiūreta $2010 \mathrm{~m}$. sausio 19 d.]. COMMUNICATION FROM THE COMMISSION TO THE COUNCIL AND THE EUROPEAN PARLIAMENT. Brussels. Prieiga per internetą: <http://ec.europa.eu/archives/growthandjobs/pdf/ COM2005_330_en.pdf> 
Construction sector council [interaktyvus]. 2010. [žiūrèta 2010 m. sausio 19d.]. Prieiga per internetą: $<$ http://www.constructionforecasts.ca/lmi-program>

Davis, E., P., Karim, D. 2008. Could Early Warning Systems Have Helped To Predict the Sub-Prime Crisis? [interaktyvus]. National Institute Economic Review 206: 35-47 [žiūrèta $2009 \mathrm{~m}$. lapkričio $12 \mathrm{~d}$.]. Prieiga per internetą: <http://ner.sagepub. com/content/206/1/35.full.pdf + html $>$

Demyanyk, Y., Hasan, I. 2009a. Financial crises and bank failures: A review of prediction methods [interaktyvus]. Publisher: Bank of Finland. ISBN 978-952-462-565-4 [žiūrèta $2010 \mathrm{~m}$. vasario $22 \mathrm{~d}$.]. Prieiga per internetą: <http://www.bof.fi/ NR/rdonlyres/E6DB3500-E52F-49BA-99D4-59A9BBF6FA4D/0/0935netti.pdf>

Demyanyk, Y, Van Hemert, O. 2009b. Understanding the subprime mortgage crisis [interaktyvus]. Oxford journals: Review of Financial Studies. [žiūrèta 2009m. liepor 17 d.]. Prieiga per interneta: <http://rfs.oxfordjournals.org/content/early/2009/05/04/ rfs.hhp033.full>

Detemmerman, V., 2009. Impact of the crisis on the construction industry [interaktyvus]. [žiūrèta $2009 \mathrm{~m}$. lapkričio 23d.]. Prieiga per internetą: <http://eesc.europa.eu/sections/ ccmi/Hearingsandconferences/Thepast/Financial_crisis/documents/Detemmerman_Vinc ent.ppt>

Dejus, T. 2002. The model of determining the sensitivy of elements of multiple criteria evaluation methods. Journal of Civil Engineering and Management 8(4): 263-268.

Die Wirtschaftskammern Österreichs [interaktyvus] [Austrijos prekybos rūmai]. [žiūrèta 2009 m. lapkričio 09d.]. Prieiga per interneta: < <ttp://portal.wko.at/wk/format detail.wk?AngID $=1 \& \mathrm{StID}=463306 \& \mathrm{DstID}=597>$

Dobryninas, A., Gaidys, V. 2004. Ar saugi Lietuvos visuomenè? (Lietuvos gyventoju viktimizacijos patirtis ir požiūris į baudžiamają justiciją bei visuomenès sauguma). Lietuvos Respublikos Seimas, Jungtinių Tautu vystymo programa. Vilnius, 92 p. ISBN: 9955-534-70-2

Economic sectors: Construction [interaktyvus]. 2008. (Industry overview) (Geographic Overview). Economist Intelligence Unit: Country Profile: Sweden. Economist Intelligence Unit N.A. Incorporated. [žiūrèta 2008 m. spalio 10 d.]. Prieiga per internetą: $<$ http://find.galegroup.com/itx/start.do?prodId=ITOF>

Elenkov, D., Fileva, T. 2006. Anatomy of a business failure: Accepting the "bad luck" explanation vs proactively learning in international business. Cross Cultural Management: An International Journal 13(2): 132-141. ISSN: 1352-7606.

EU Directive 96/61/EC [interaktyvus]. [žiūrèta 2007 10 11]. Prieiga per internetą: $<\mathrm{http} / / /$ ec.europa.eu/environment/ippc/index.htm>

Eurostat [interaktyvus]. [žiūrèta $2011 \mathrm{~m}$. balandžio 3d.]. Prieiga per internetą: $<$ http://epp.eurostat.ec.europa.eu/portal/page/portal/eurostat/home/> 
Fellows, R. Liu, A. 2008. A culture-based approach to the management of conflict on multi-national construction projects: participants and performance [interaktyvus]. International Conference on Multi-National Construction Projects: Securing High Performance Through Cultural Awareness and Dispute Avoidance, Shanghai, China, November 21-23. [žiūrèta $2009 \mathrm{~m}$. vasario $18 \mathrm{~d}$.]. Prieiga per internetą: $<$ http://www.irbnet.de/daten/iconda/CIB12140.pdf $>$

Gallup International Association [interaktyvus]. 2007. [žiūrèta 200712 20]. Prieiga per internetą: $<$ http://www.gallup-international.com/>

Gibson, G. E.; Davis-Blake, A.; Dickson, K. E.; Mentel, B. 2003. Workforce Demographics among Project Engineering Professionals-Crisis Ahead? ASCE Journal of Management in Engineering 19(4): 173-182.

Gilbert, D. C.; DeVilbiss, C. 2010. Engineering Leadership and Management during Financial Crisis. Leadership and Management in Engineering 10(1): 4-9.

Green, D. 2009. Can America's Engineering Crisis Be Prevented? Leadership and Management in Engineering 9(1): 2-3.

Günthner, W. A., Kessler, S., Sanladerer, S. 2007. Transportlogistik in der Baubranche Optimierung durch den Einsatz eines Flottenmanagementsystems. Jahrbuch Logistik: 252-256. ISBN 3-9809412-3-X

Gupta, R., Kabundi, A., Miller, S. M. 2009. Using Large Data Sets to Forecast Housing Prices: A Case Study of Twenty US States [interaktyvus]. University of Connecticut. Department of Economics. Working Paper 2009-13. [žiüreta 2009 m. spalio 15 d.]. Prieiga per interneta: $<$ http://www.econ.uconn.edu/working/2009-13.pdf $>$

Haslem, J. A., Scheraga, C. A, Bedingfield, J. P. 1992. An analysis of the foreign and domestic balance sheet strategies of the U.S. banks and their association to profitability performance. Management International Review 1992; First Quarter.

Heintz, J., Pollin, R., Garrett-Peltier, H. 2009. How Infrastructure Investments Support the U.S. [interaktyvus]. Economy: Employment, Productivity, and Growth, Political Economy Research Institute and Alliance for American Manufacturing, January. [žiūrèta 2009 m. liepos 24 d.]. Prieiga per interneta: <http://www.peri.umass.edu/fileadmin/pdf/ other_publication_types/green_economics/PERI_Infrastructure_Investments $>$

Hwang, C. L.; Yoon, K. 1981. Multiple Attribute Decision Making Methods and Applications. Berlin, Heidelberg, New York: Springer-Verlag.

Iacoviello, M., Neri, S. 2008. Housing market spillovers: Evidence from an estimated DSGE model [interaktyvus]. Temi di discussione (Economic working papers), Bank of Italy, Economic Research Department. [žiūrèta 2008 m. gruodžio 12 d.]. prieiga per internetą: <http://www.bancaditalia.it/pubblicazioni/econo/temidi/td08/td659_08/td659 /en_tema_659.pdf>

Infostatyba - Lietuvos Respublikos statybos leidimu ir statybos valstybinès priežiūros informacinè sistema [interaktyvus]. [žiūrèta $2009 \mathrm{~m}$. lapkričio 30 d.]. Prieiga per internetą: <https://www.planuojustatyti.lt/infostatyba_isorine/> 
Yasamis, F., Arditi, D., Mohammadi, J. 2002. Assessing contractor quality performance. Construction Management and Economics 20(3): 211-223. ISSN 0144-6193.

Yisa, S., Ndekugri, I., Ambrose, B. 1996. A review of changes in the UK construction industry: their implications for the marketing of construction servines. European Journal of Marketing 30(3): 47-65. ISSN: 0309-1566.

Josephson, P. E., Larison, B., Li, H. 2002. Illustrative Benchmarking Rework and Rework Costs in Swedish Construction Industry. Journal of management in engineering 18(2): 76-83, (doi 10.1061/(ASCE)0742-597X(2002)18:2(76)).

Kaklauskas, A.; Zavadskas, E. K.; Banaitis, A.; Šatkauskas, G. 2007. Defining the utility and market value of a real estate: a multiple criteria. International journal of strategic property management 11(2): 107-120. ISSN 1648-715X.

Kaklauskas, A.; Zavadskas, E. K.; Ditkevičius, R. 2006. An intelligent tutoring system for construction and real estate. Lecture Notes in Computer Science 4101: 174-181. ISSN 0302-9743.

Kaklauskas, A.; Zavadskas, E. K. 2002a. Internetinè sprendimų parama: monografija. Vilnius: Technika. $216 \mathrm{p}$.

Kaklauskas, A.; Zavadskas, E. K.; Vainiūnas, P.; Trinkūnas, V. 2002b. Construction calculators, analyzers, software, experts and decision support systems, their integration and applications. Second International Conference on Information Systems in Engineering and Construction. Department of Construction Management University of Nebraska Lincoln, 8-18.

Kaklauskas, A.; Zavadskas, E. K.; Vainiūnas, P. 2001. Efficiency Increase of real estate e-business systems by applying multiple criteria decision support systems. Eighth European real estate society conference: Alicante, June 26-29, 2001: proceedings [CD]. University of Alicante, 11-24.

Kaklauskas, A. 1999. Multiple criteria decision support of building life cycle: Research report presented for habilitation. Vilnius Gediminas Technical University, Vilnius.

Kaklauskas, A.; Zavadskas, E. K.; Ambrasas, G. 1998. Increase of student study efficiency through the application of multiple criteria decision support systems, in Monash Engineering Education Series. Seminar Proceeding [2nd Baltic Region Seminar on Engineering Education Riga Technical University, Riga, Latvia]. Edited by Zenon J. Pudlowski and John D. Zakis. UNESKO International Centre for Engineering Education (UICEE) Faculty of Engineering Monash University, Clayton, Melbourne, VIC 3168, Australia, 128-134.

Knowledge@Wharton [interaktyvus]. 2009. Hope, Greed and Fear: The Psychology Behind the Financial Crisis. [žiūrèta 2009 m. lapkričio 23 d.]. Prieiga per internetą: $<$ http://www.ftpress.com/articles/article.aspx?p=1338641>

Lam, P. T. I.; Chiang, Y. H.; Chan, S. H. 2011. Critical Success Factors for Bond Financing of Construction Projects in Asia. ASCE Journal of Management in Engineering 
doi:10.1061/(ASCE)ME.1943-5479.0000063 (Submitted 25 May 2010; accepted 22 March 2011; posted ahead of print 23 March 2011).

Legkauskas, V. 2009. Psichoekonomika, arba psichologo žvilgsnis į ekonominio nuosmukio priežastis. Psichologija tau. 2009 rugsèjis/spalis.

Lietuvos bankas [interaktyvus]. 2010. [žiūrèta 2011 m. kovo 4 d.]. Prieiga per internetą: $<$ http://www.lb.lt/>

Lietuvos laisvosios rinkos institutas [interaktyvus]. 2009. 23-asis Lietuvos ekonomikos tyrimas (2008/2009) (2). [žiūrèta 2009 m. lapkričio 23 d.]. Prieiga per internetą: $<$ http://www.lrinka.lt/index.php/analitiniai_darbai/23_asis_lietuvos_ekonomikos_tyrim as_20082009_2/5407;from_topic_id;5091>

Lietuvos Respublikos konstitucija (Žin., 1992, Nr. 33-1014), nauja 47 straipsnio redakcija nuo $2003 \mathrm{~m}$. vasario $7 \mathrm{~d}$.

Lietuvos Respublikos Statistikos departamento metraštis [interaktyvus]. 2008. Statistikos departamentas prie Lietuvos respublikos Vyriausybès. Vilnius, 740 p. [žiūrèta 2009 m. spalio 15 d.]. Prieiga per internetą: <http://www.stat.gov.lt/lt/catalog/list/?cat_ $\mathrm{y}=2 \&$ cat_id $=1>$

Lietuvos Respublikos statybos istatymas [interaktyvus]. Nr. I-1240. 1996 m. kovo 19 d. (Lietuvos Respublikos $2001 \mathrm{~m}$. lapkričio 8 d. istatymo Nr. IX-583 (nuo $2002 \mathrm{~m}$. liepos 1 d.) (Žin., 2001, Nr. 101-3597) redakcija). [žiūrèta 2008 m. rugsejo 11 d.]. Prieiga per internetą: $<\mathrm{http}: / / \mathrm{www} 3$. Irs.lt/pls/inter2/dokpaieska.showdoc_1?p_id=26250>

Lietuvos ūkio (ekonomikos) plètros iki 2015 metų ilgalaikè strategija [interaktyvus]. 2002. Lietuvos Respublikos Úkio ministerija, Lietuvos mokslu akademija. [žiūrèta 2009 $\mathrm{m}$. spalio 15 d.]. Prieiga per internetą: <http://www.ukmin.lt/lt/strategija/ VIRS/Ūkio\%20strategija/galutine040121.doc>

Lim, B. T. H.; Ling, F. Y. Y.; Ibbs, C. W.; Raphael, B.; Ofori, G. 2011. Empirical Analysis of the Determinants of Organizational Flexibility in the Construction Business. ASCE Journal of Construction Engineering and Management 137(3): 225-237.

Loosemore, M.; Teo, M. M. M. 2000. Crisis Preparedness of Construction Companies. ASCE Journal of Management in Engineering 16(60): 51-60.

Loosemore, M. 1997. Construction Crises as Periods of Social Adjustment. Journal of Construction Engineering and Management 13(4): 30-37.

Lovelock, C. 1997. Fear of a recession: the best way to deal with it is to prepare for it. Marketing Management 6(3): 14-17.

Lu, C., So, R.W., 2005. Return Relationships between Listed Banks and Real Estate Firms: Evidence from Seven Asian Economies. The Journal of Real Estate Finance and Economics 31 (2), 189-206. ISSN: 1573-045X.

Marwa, S., Zairi, M. 2008. An exploratory study of the reasons for collapse of contemporary companies and their link to the concept of quality. Journal: Management Decision 46(9): 1342-1370. ISSN: 0025-1747. 
McKibbin, W. J., Stoeckel. A. 2009. Modelling The Global Financial Crisis [interaktyvus]. Centre For Applied Macroeconomic Analysis Working Paper Series. The Australian National University: 44 p. [žiūrèta 2010 m. sausio 16 d.]. Prieiga per internetą: $<$ http://cama.anu.edu.au/Working\%20Papers/Papers/2009/McKibbin

Stoeckel252009.pdf>

Montana, P.J., Charnov, B.H., 2008. Management (4th ed.). Barrons educational series. Hauppauge, $552 \mathrm{p}$.

Montuori, L. A. 2000. Organizational longevity - Integrating systems thinking, learning and conceptual complexity. Journal of Organizational Change Management 13(1): 6173. ISSN: 0953-4814.

Naaranoja, M., Uden, L. 2007. Major problems in renovation projects in Finland. Building and Environment 42(2): 852-859. ISSN 0360-1323.

Nafday, A. M. 2011. Strategies for Professional Engineering Firms during Economic Recession. Journal of Professional Issues in Engineering Education and Practice 137(1): 7-11.

Nehdi, M. 2002. Crisis of Civil Engineering Education in Information Technology Age: Analysis and Prospects. Journal of Professional Issues in Engineering Education and Practice 128(3): 131-137.

Nekilnojamojo kultūros paveldo apsaugos istatymas [interaktyvus]. Nr. I-733, 1994 m. gruodžio 22 d. (Žin., 1995, Nr. 3-37). [žiūrèta 2009 m. gegužès 5 d.]. Prieiga per internetą: $\quad<$ http://www3.lrs.lt/pls/inter2/dokpaieska.showdoc_1?p_id=243361\&p_ query $=\& p \_$tr2 $=>$

News.World-Estate.com [interaktyvus]. [žiūrèta 2009 m. rugpjūčio 30 d.].Prieiga per internetą: <http://www.world-estate.com/>

Ocal, E., Oral, E.L., Erdis, E., 2006. Crisis management in Turkish construction industry. Building and Environment 41(11): 1498-1503. ISSN 0360-1323.

Penkaitis, N. 2008. Vokietijos ekonomikos nuosmukis - išvados Lietuvai [interaktyvus]. [žiūrèta $2008 \mathrm{~m}$. spalio $06 \mathrm{~d}$.]. Prieiga per internetą: <http://www.lsds.lt/documents/ Vokietijos\%20ekonomikos\%20klaidos\%20II.doc>

Phoenix sindrome [interaktyvus]. 2009. [žiūrèta 2009 11 23]. Prieiga per internetą: $<$ http://www.breakingnews.ie/archives/2007/0603/business/mhkfmhojcwql/\#ixzz0Vrgen ETI $>$

Pilipaitè, R. 2006. Komercinių santykių konfidencialumas [interaktyvus]. Verslo žinios, 2006 12 01. [žiūrèta 200911 30]. Prieiga per internetą: <http://archyvas.vz.lt/ news.php?id $=491260 \&$ strid $=1002 \& \mathrm{rs}=0 \&$ ss $=1 \& \mathrm{y}=2006 \% 2012 \% 2001>$

Popov, V., T. Grigorjeva. 2010. Statybinių konstrukcijų integruotas automatizuotas projektavimas. Statybines konstrukcijos ir technologijos. Engineering structures and technologies 2(1): 31-37. ISSN 2029-2325. 
Raslanas, S. 2001. Žemės ir statinių vertinimas: paskaitų konspektas. Vilnius: elektroninè laikmena, $117 \mathrm{p}$.

Regan, M.; Smith, J.; Love, P. E. D. 2011. Impact of the Capital Market Collapse on Public-Private Partnership Infrastructure Projects. Journal of Construction Engineering and Management 137(1): 6-16.

Registru centras [interaktyvus]. [žiūrèta 2009 m. birželio 11 d.]. Prieiga per internetą: $<\mathrm{http} / / / \mathrm{www}$. registrucentras.lt/>

Rojas, E. M. 2000. Diagnostic and Crisis Management Simulations for Construction Engineering Education. Computing in Civil and Building Engineering, Proceedings of the Eighth International Conference on Computing in Civil and Building Engineering (2000): 1164-1171.

Sheridan, J. 1997. Managing peaks and valleys. Industry Week 246(20): 13-14.

Spink, Ch. 2008. Construction: building the new Europe: the construction sector in Central and Eastern Europe continues to grow at above the rate of many of the region's burgeoning economies. This is encouraging acquirers to look at consolidation opportunities. (Central Eastern Europe Report). Acquisitions Monthly 283 (May 2008): S18(4).

Sriraj, P. S.; Khisty, C. J. 1999. Crisis Management and Planning Using Systems Methodologies. Journal of Urban Planning and Development 125(3): 121-133.

Statistikos departamentas prie Lietuvos vyriausybès [interaktyvus]. [žiūrèta $2011 \mathrm{~m}$. balandžio $04 \mathrm{~d}$.]. Prieiga per internetą: <http://www.stat.gov.lt/lt/>

STR 1.01.09:2003 Statiniu klasifikavimas pagal ju naudojimo paskirti. Vilnius, 2003. $11 \mathrm{p}$.

Tam, K. Y. 1991. Neural network models and the prediction of bank bankruptcy. Omega 19(5): 429-445.

Tijhuis, W. 2008. Understanding multi-cultural performance in construction: a tool for dispute avoidance? International Conference on Multi-National Construction Projects: Securing High Performance Through Cultural Awareness and Dispute Avoidance, SHANGHAI, CHINA, November 21-23, 2008.

UGMK.info [interaktyvus]. [žiūrèta $2009 \mathrm{~m}$. lapkričio 05 d.]. Prieiga per internetą: $<$ http://ugmk.info/news/avantazh-nadeetsja-prodat-doli-v-7-obektah-kommercheskojnedvizhimosti-v-harkove.html>

Valstietis.lt [interaktyvus]. [žiūrèta $2009 \mathrm{~m}$. gegužès 20 d.]. Prieiga per internetą: $<$ http://www.valstietis.lt/Rubrikos/Verslas/Lietuvos-BVP-gali-smukti-10-5-proc>

Wang, S. Q.; Tiong, R. L. K.; Ting, S. K.; Ashley, D. 2000. Evaluation and Management of Political Risks in China's BOT Projects. Journal of Construction Engineering and Management 126(3): 242-250. 
Zavadskas, E. K.; Kaklauskas, A; Raslanas, S. 2005. Multivariant design and multiple criteria analysis of building refurbishments. Energy and Buildings 37(4): 361-372. ISSN 0378-7788.

Zavadskas, E. K.; Kaklauskas, A., Viteikienè, M. 2004. Decision support of web-based system for construction innovation, in The international Conference "Reliability and Statistics in Transportation and Communication" (RelStat' 04), 14-15 October 2004, Riga, Latvia: programme and abstracts. Riga: Transport and Telecommunication Institute, $1-8$.

Zavadskas, E. K.; Kaklauskas, A.; Vainiūnas, P.; Kutut, V.; Turskis, Z. 2003. Nekilnojamojo turto sektoriaus internetinių sistemų efektyvumo didinimas taikant daugiakriterines paramos sistemas. Journal of Civil Engineering and Management 9(2): 83-90. ISSN 1392-3730.

Zavadskas, E. K.; Kaklauskas, A; Banaitienė, N. 2001. Pastato gyvavimo proceso daugiakriteriné analizè. Vilnius: Technika. 379 p. ISBN 9986-05-441-9.

Zavadskas, E. K. 2000. Pastatu statybos technologija (paskaitu konspektas). Vilnius: elektroninè laikmena, $220 \mathrm{p}$.

Zavadskas, E. K. 1987. Multiple criteria evaluation of technologica decisions of construction: Dissertation of $\mathrm{Dr} \mathrm{Sc}$ (in Russian). Moscow Civil Engineering Institute, Moscow. 


\section{Autorès publikacijos disertacijos tema}

\section{Straipsniai recenzuojamuose mokslo žurnaluose}

Kaklauskas, A.; Zavadskas, E. K.; Bagdonavičius, A.; Kelpšienė, L.; Bardauskienè, D.; Kutut, V. 2010. Conceptual modelling of construction and real estate crisis with emphasis on comparative qualitative aspects description, Transformations in Business \& Economics 9(1): 42-61. ISSN 1648-4460 (ISI Web of Science).

Kaklauskas, A.; Kelpsiene, L.; Zavadskas, E. K.; Bardauskiene, D.; Kaklauskas, G.; Urbonas, M.; Sorakas, V. 2011. Crisis management in construction and real estate: Conceptual modeling at the micro-, meso- and macro-levels / Original Research Article, Land Use Policy 28(1): 280-293. ISSN 0264-8377 (ISI Web of Science).

Kelpšienè, L.; Matusevičienè, M. L. 2009. Bendros ekonominè krizès ittakos statybos imonei tyrimas. Jaunuju mokslininku darbai 3(24): 49-57. ISSN 16488776 (CEEOL, Index Copernicus).

Petrosius, J.; Kelpsiene, L. 2010. Overview of reaction to the economic crisis in construction and real estate modelling. Jaunuju mokslininku darbai 1(26) 106115. ISSN 1648-8776 (CEEOL, Index Copernicus). 


\section{Priedai}

A priedas. Daugiabučių namų modernizavimo projektụ igyvendinimo variantų kompleksinis kriteriju reikšmingumų nustatymas

B priedas. Vilos parko ir statinių rekonstrukcijos igyvendinimo kompleksinis kriteriju reikšmingumų nustatymas

C priedas. Daugiabučių namų modernizavimo projektų igyvendinimo variantų daugiakriterinès analizès rezultatai

D priedas. Vilos parko ir statiniu rekonstrukcijos igyvendinimo daugiakriterinès analizès rezultatai

E priedas. Pakruojo dvaro sodybos restauravimo projekto duomenys

F priedas. Devynaukščių namų modernizavimo projektų duomenys 



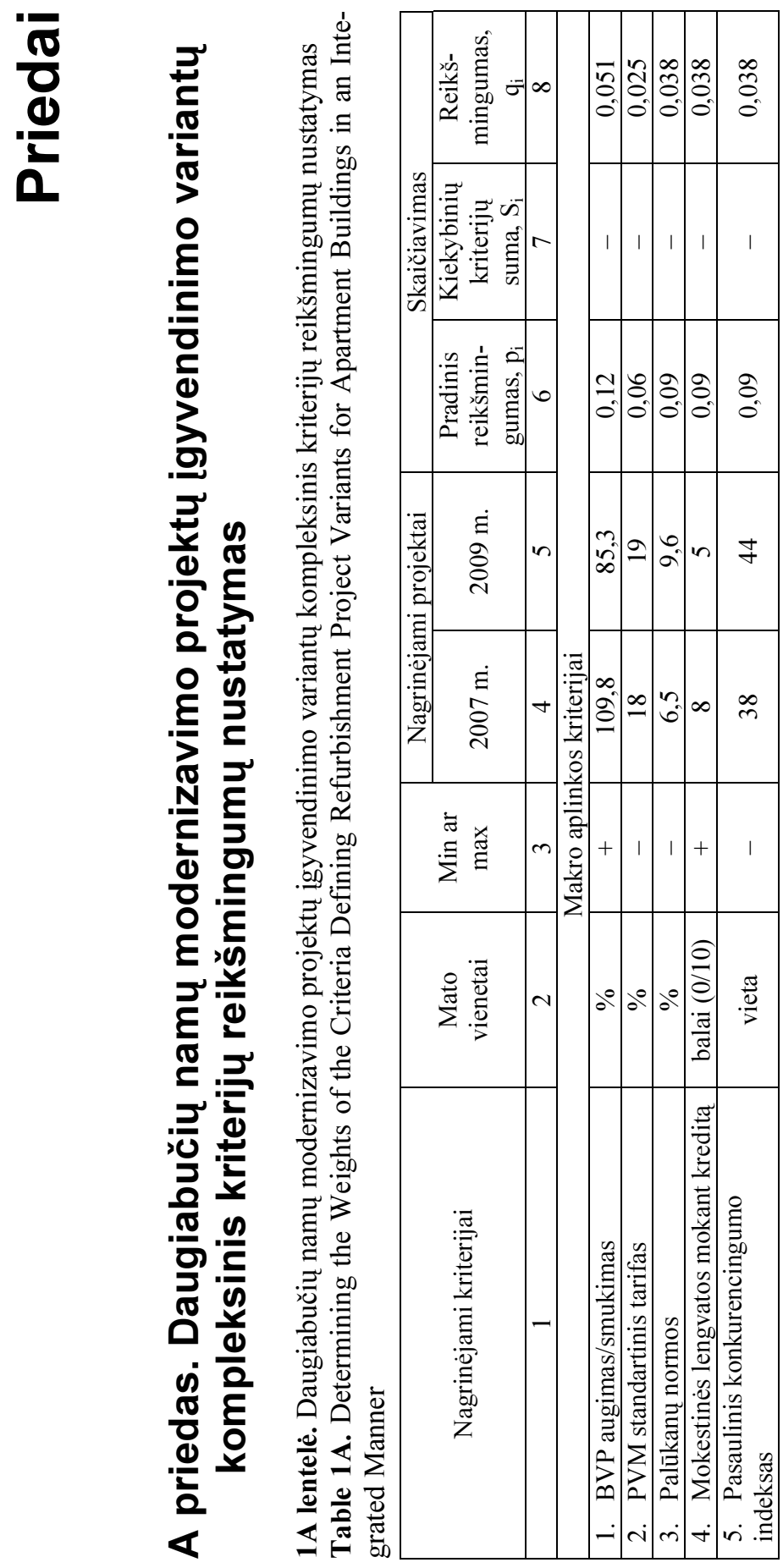




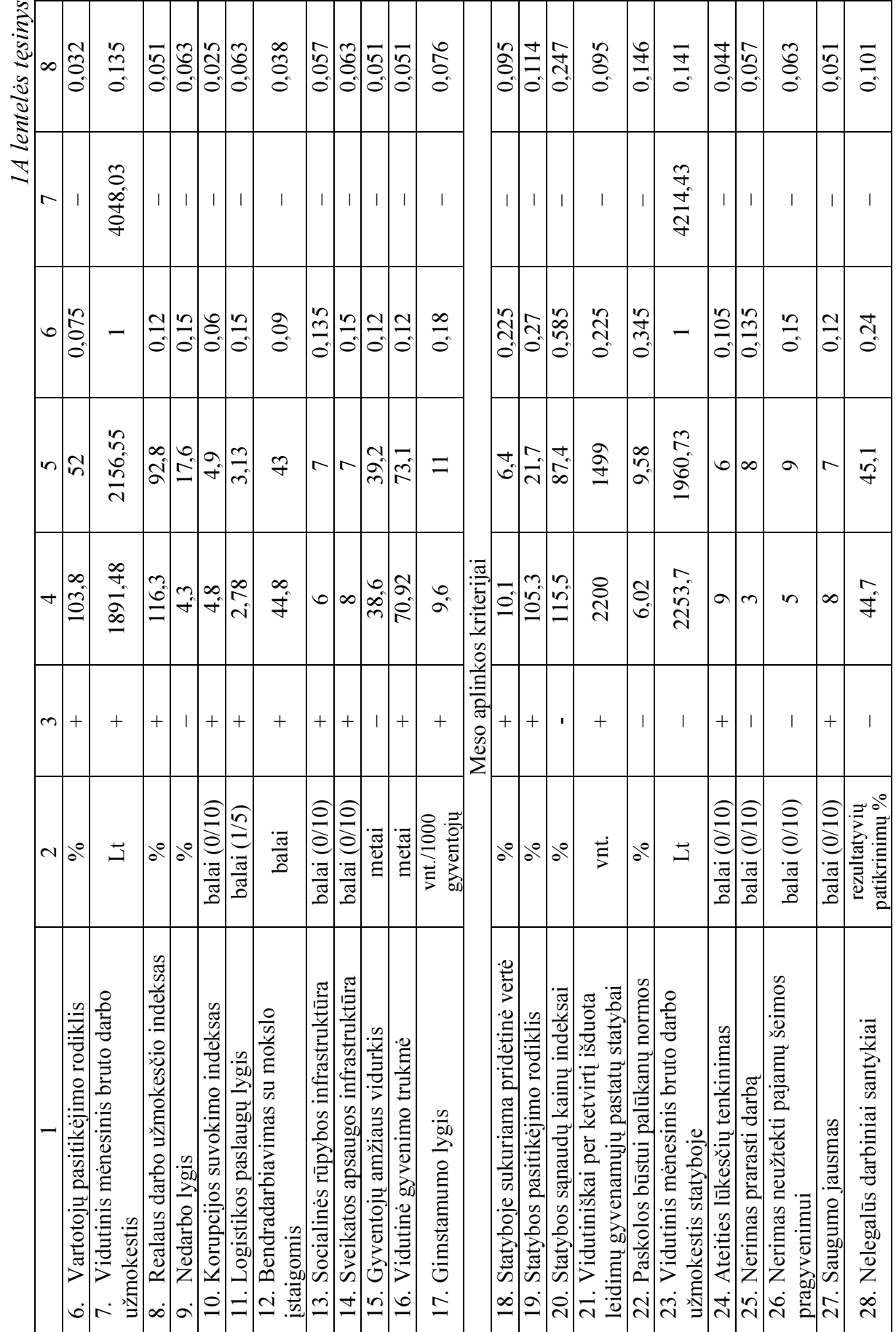




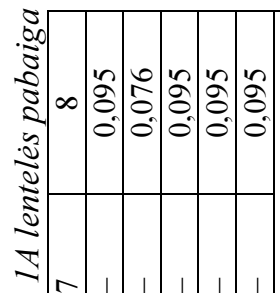

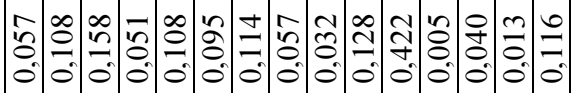

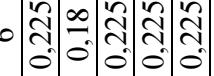

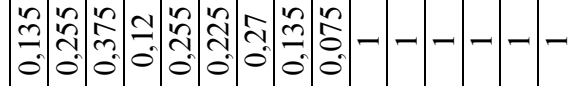

in

กิ กิ

ले

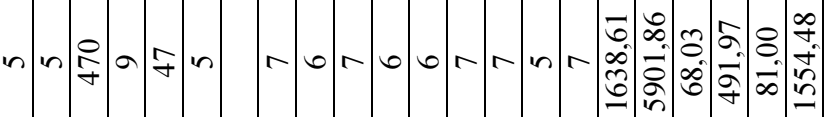

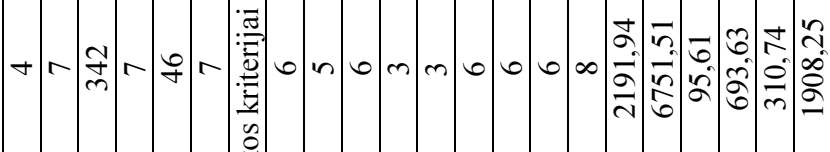

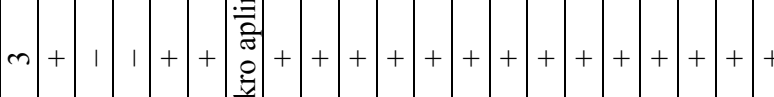

言

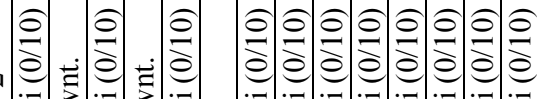

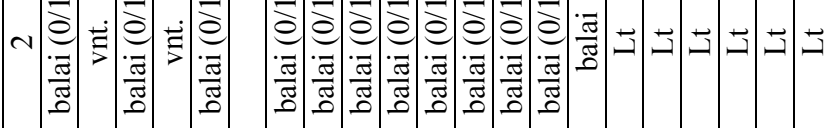

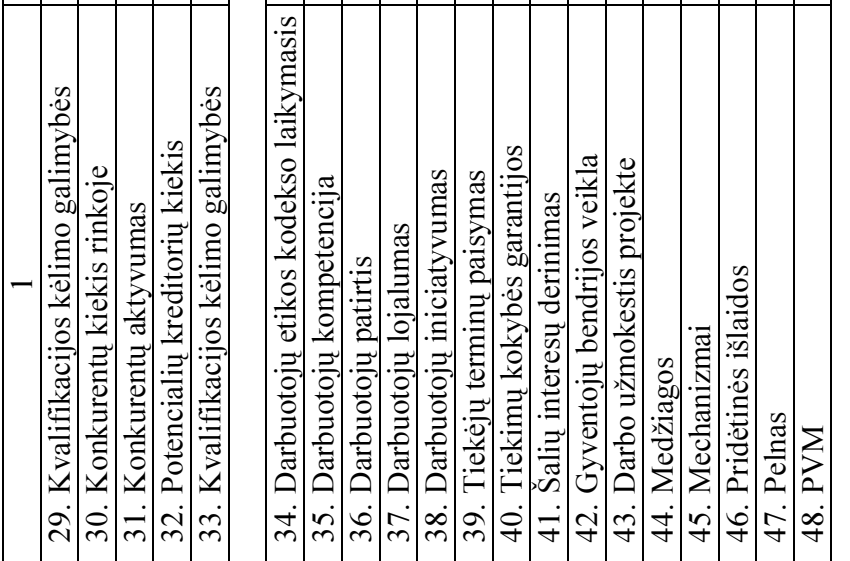




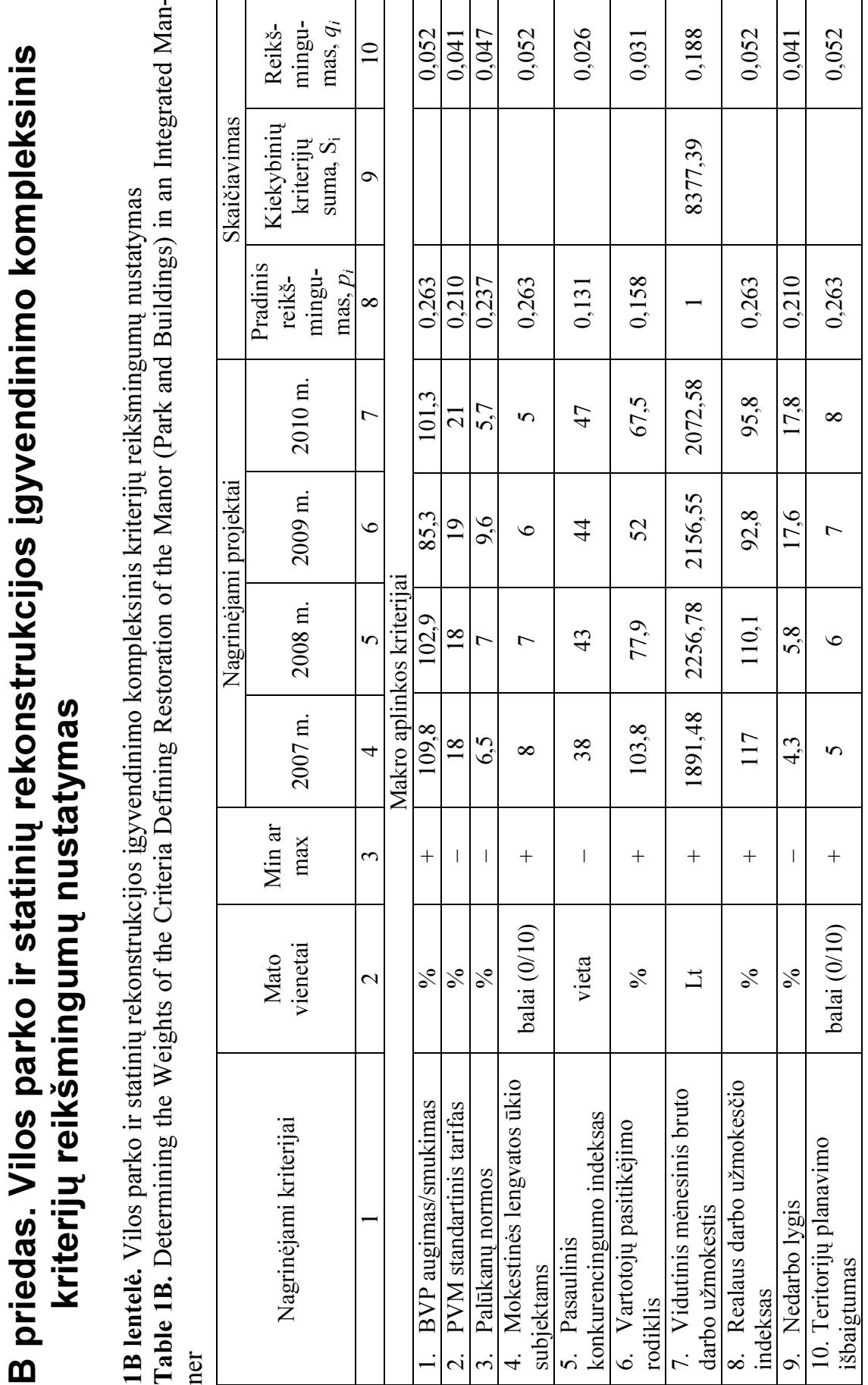




\begin{tabular}{|c|c|c|c|c|c|c|c|c|c|c|c|c|c|c|c|c|}
\hline 으 & $\underset{\Xi}{\bar{O}}$ & $\underset{0}{\tilde{O}}$ & $\frac{1}{2}$ & $\begin{array}{l}\bar{\Xi} \\
0\end{array}$ & है & $\begin{array}{l}\sqrt{2} \\
\tilde{0} \\
0 \\
0\end{array}$ & ت্ & 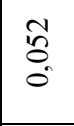 & $\begin{array}{l}0 \\
0 \\
0 \\
0\end{array}$ & $\underset{\Xi}{\Xi}$ & & 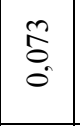 & $\begin{array}{l}\infty \\
0 \\
0\end{array}$ & $\frac{n}{0}$ & $\begin{array}{l}\vec{\sigma} \\
0 \\
0\end{array}$ & $\frac{8}{\circ}$ \\
\hline$a$ & & & & & & & & & & & & & & & & $\begin{array}{l}+ \\
\stackrel{\infty}{\circ} \\
\stackrel{+}{\infty}\end{array}$ \\
\hline$\infty$ & 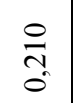 & $\hat{\tilde{n}}$ & 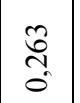 & $\frac{0}{\sqrt{n}}{ }_{0}$ & $\stackrel{\infty}{\stackrel{\infty}{0}}$ & $\begin{array}{l}\tilde{b} \\
\mathfrak{0} \\
0\end{array} \mid$ & $\frac{0}{\sqrt{n}}$ & $\begin{array}{l}\text { రై } \\
\text { Ň } \\
0\end{array}$ & $\frac{\vec{\infty}}{0^{\prime}}$ & $\frac{0}{\sqrt{2}}$ & & $\begin{array}{l}\infty \\
\infty \\
\\
0\end{array}$ & 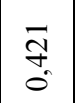 & \begin{tabular}{l}
\multirow{0}{0}{} \\
0 \\
0 \\
0
\end{tabular} & 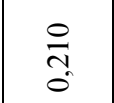 & - \\
\hline$r$ & in & $\vec{a}$ & $\stackrel{m}{n}$ & $\stackrel{n}{f}$ & $n$ & 0 & 0 & 6 & बे & $\stackrel{0}{ }$ & & $\hat{n}$ & $\stackrel{\infty}{n}$ & $\begin{array}{l}0 \\
8 \\
8\end{array}$ & 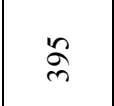 & $\begin{array}{l}3 \\
\infty \\
\curvearrowright \\
\curvearrowright\end{array}$ \\
\hline 6 & $\stackrel{\vartheta}{\sigma}$ & $\tilde{2}$ & $\stackrel{\infty}{\infty}$ & $\stackrel{\mathscr{F}}{\forall}$ & $\infty$ & $r$ & 6 & 0 & ๙ิ & $=$ & & $\vec{\sigma}^{\circ}$ & $\hat{\vec{\lambda}}$ & $\underset{\infty}{+}$ & $\tilde{n}$ & $\begin{array}{l}\Re \\
\stackrel{8}{0} \\
\stackrel{0}{0}\end{array}$ \\
\hline in & $\begin{array}{l}0 \\
f\end{array}$ & $\begin{array}{l}\infty \\
\infty \\
\infty\end{array}$ & ปี & $\begin{array}{l}0 \\
\text { i } \\
\text { f }\end{array}$ & $\vec{n}$ & $\infty$ & $r$ & $r$ & ले & $\stackrel{n}{0}$ & : & $\sigma^{2}$ & $\bar{n}$ & $\stackrel{+}{\circ}$ & in & 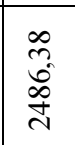 \\
\hline$\nabla$ & $\stackrel{\infty}{\ominus}$ & $\begin{array}{l}0 \\
I \\
=\end{array}$ & 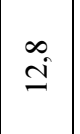 & $\begin{array}{l}\infty \\
\dot{f}\end{array}$ & 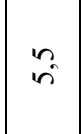 & 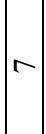 & 0 & $\infty$ & $\begin{array}{l}0 \\
\infty \\
\infty\end{array}$ & $\begin{array}{l}0 \\
a\end{array}$ & $\mid \begin{array}{l}0 \\
\overline{0} \\
0 \\
0 \\
0 \\
0\end{array}$ & $\ddot{0}$ & $\stackrel{m}{n}$ & $\stackrel{n}{=}$ & 离 & $\hat{\tilde{n}}$ \\
\hline$m$ & + & + & + & + & + & + & + & + & 1 & + & & + & + & 1 & + & 1 \\
\hline$v$ & $\begin{array}{l}\underset{0}{0} \\
\stackrel{0}{e} \\
\frac{\pi}{\pi} \\
\frac{\pi}{0}\end{array}$ & 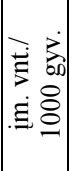 & $\partial^{0}$ & $\frac{\pi}{\pi}$ & $\partial^{0}$ & 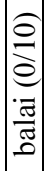 & 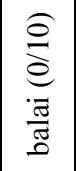 & 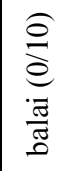 & 丞 & 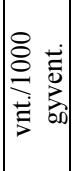 & & $\partial^{\circ}$ & $\partial^{0}$ & $\partial^{0}$ & $\dot{\vec{J}}$ & 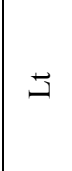 \\
\hline- & 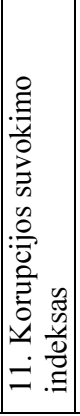 & 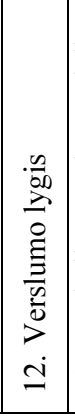 & 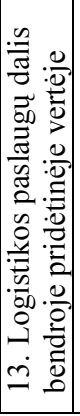 & 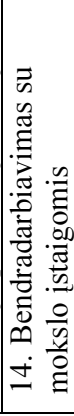 & 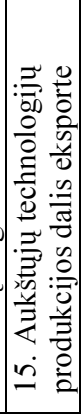 & 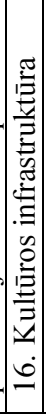 & 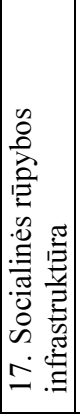 & 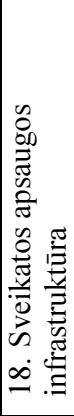 & 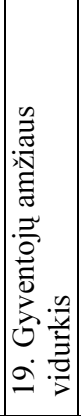 & 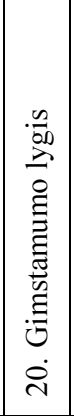 & & 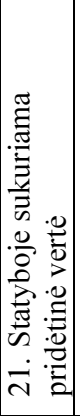 & 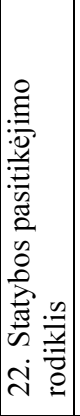 & 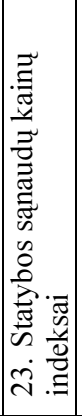 & 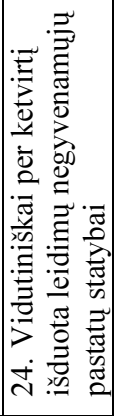 & 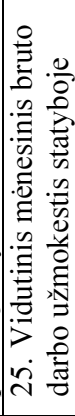 \\
\hline
\end{tabular}




\begin{tabular}{|c|c|c|c|c|c|c|c|c|c|c|c|c|c|c|c|c|c|c|c|c|c|}
\hline 으 & $\begin{array}{l}\text { O } \\
0 \\
0\end{array}$ & 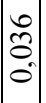 & 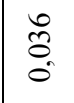 & $\begin{array}{c}\bar{n} \\
0 \\
0\end{array}$ & 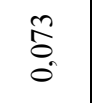 & $\frac{5}{0}$ & $\begin{array}{l}7 \\
\dot{J} \\
0\end{array}$ & $\begin{array}{l}\text { Tे } \\
0 \\
0\end{array}$ & $\begin{array}{l}\mathscr{M} \\
0 \\
0 \\
0\end{array}$ & $\mid \begin{array}{l} \pm \\
\\
\end{array}$ & & $\begin{array}{l}\text { రु } \\
0 \\
0\end{array}$ & & & 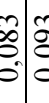 & 更 & $\frac{n}{2}$ & $\mid \begin{array}{l}2 \\
\hat{0} \\
0\end{array}$ & $\stackrel{5}{\hat{\sigma}}$ & & 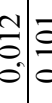 \\
\hline$a$ & & & & & & & & & & & & & & & & & & & $\underset{\infty}{\stackrel{\infty}{\infty}}$ & 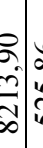 & 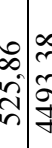 \\
\hline$\infty$ & $\begin{array}{l}\hat{\tilde{n}} \\
\hat{0}\end{array}$ & $\left|\begin{array}{l}\infty \\
0 \\
0\end{array}\right|$ & $\frac{\vec{\infty}}{0}$ & \begin{tabular}{c}
$\infty$ \\
$\stackrel{n}{2}$ \\
\hdashline \\
0
\end{tabular} & $\begin{array}{l}\infty \\
0 \\
n \\
0\end{array}$ & $\begin{array}{l}0 \\
\text { N } \\
\text { ô }\end{array}$ & $\begin{array}{l}0 \\
\bar{v} \\
0\end{array}$ & $\frac{0}{n}$ & 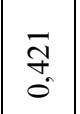 & $\left|\begin{array}{l}2 \\
n \\
0 \\
0\end{array}\right|$ & & $\frac{0}{n}$ & $\left|\begin{array}{c}\mathcal{y} \\
\infty \\
0 \\
0\end{array}\right|$ & $\stackrel{2}{2}=$ & 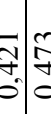 & 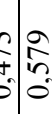 & $\mid \begin{array}{l}0 \\
\infty \\
0 \\
0\end{array}$ & $\mid \begin{array}{c}\tilde{g} \\
\underset{f}{f} \\
0\end{array}$ & - & & $-1-$ \\
\hline$r$ & 6 & $r$ & 6 & in & $\stackrel{?}{q}$ & 6 & $\tilde{\mathscr{F}}$ & $a$ & $\bar{\nabla}$ & in & & $r$ & 1 & $\sim r$ & 10 & $0 \infty$ & 1 & H & & 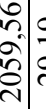 & 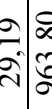 \\
\hline 0 & in & $\infty$ & $r$ & $r$ & $\vec{f}$ & in & 守 & $a$ & F & $m$ & & $r$ & 0 & $r$ & $6 \mid 0$ & $0 \infty$ & 1 & in & 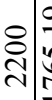 & 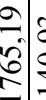 & 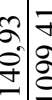 \\
\hline in & $\nabla$ & $a$ & $\infty$ & 0 & $\overrightarrow{\widetilde{f}}$ & $\nabla$ & m. & $\infty$ & N & 1 & 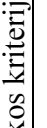 & in & in & ( & $n$ in & $r$ & 0 & in & & $\begin{array}{ll}0 \\
\frac{0}{\infty} \\
\frac{\infty}{2} & ?\end{array}$ & 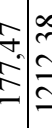 \\
\hline$\nabla$ & $a$ & $m$ & in & $\infty$ & f & $r$ & 离 & in & fo & $a$ & 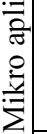 & 6 & in & (0) & $m \mid c$ & 0 & 0 & 6 & & 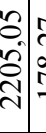 & 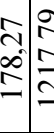 \\
\hline$m$ & + & 1 & 1 & + & 1 & + & 1 & 1 & + & + & & + & + & + & ++ & ++ & + & + & +- & + & ++ \\
\hline$N$ & $\begin{array}{l}\frac{a}{a} \\
\frac{a}{a} \\
\frac{\pi}{a}\end{array}$ & 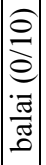 & 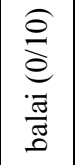 & 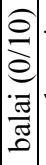 & 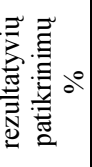 & $\underset{\frac{0}{0}}{\stackrel{0}{0}}$ & $\dot{\vec{\xi}}$ & 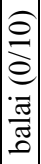 & $\dot{\vec{\xi}}$ & 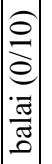 & & 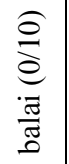 & 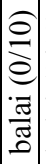 & 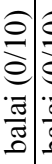 & 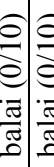 & 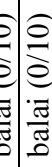 & $\left\{\begin{array}{l}0 \\
\frac{0}{e} \\
\cdot \frac{\pi}{\pi} \\
0\end{array}\right.$ & 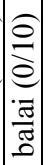 & 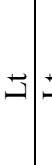 & ב & $\sqsupset$ \\
\hline - & 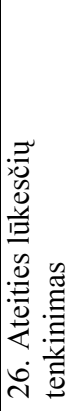 & 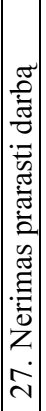 & 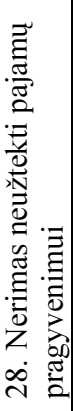 & 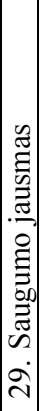 & 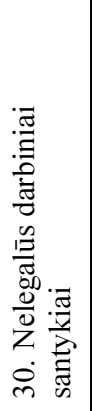 & 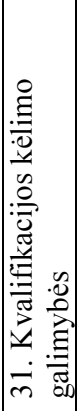 & 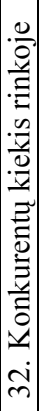 & 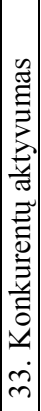 & 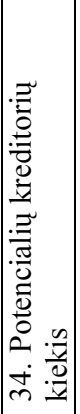 & 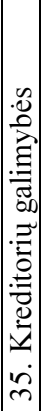 & & 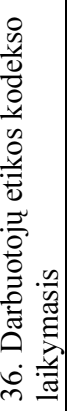 & 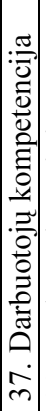 & 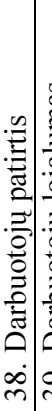 & 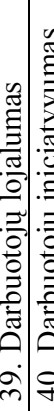 & 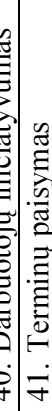 & 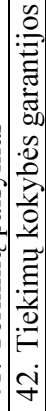 & 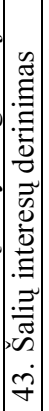 & 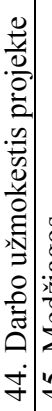 & 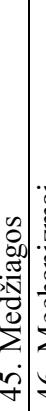 & 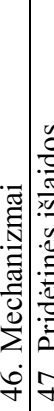 \\
\hline
\end{tabular}




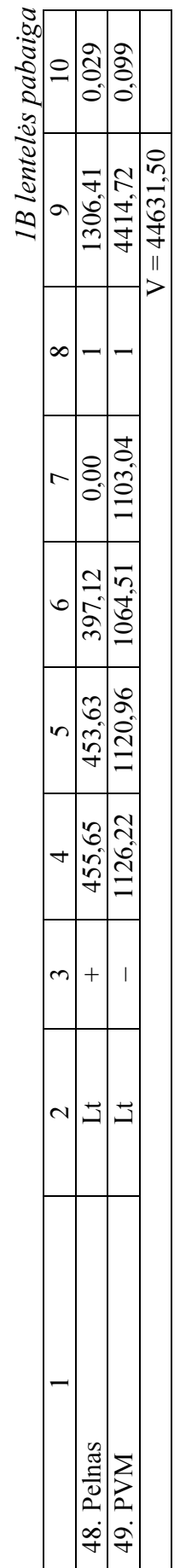




\section{C priedas. Daugiabučių namų modernizavimo projektų igyvendinimo variantų daugiakriterinès analizès rezultatai}

1C lentelè. Daugiabučių namų modernizavimo projektų igyvendinimo variantų daugiakriterinès analizès rezultatai

Table 1C. Results of the Multiple Criteria Analysis of Refurbishment Project Variants for Apartment Buildings

\begin{tabular}{|c|c|c|c|c|c|}
\hline \multirow{2}{*}{ Nagrinèjami kriterijai } & \multirow{2}{*}{$\begin{array}{l}\text { Mato } \\
\text { vienetai }\end{array}$} & \multirow{2}{*}{$\begin{array}{l}\text { Min } \\
\text { ar } \\
\max \end{array}$} & \multirow{2}{*}{$\begin{array}{l}\text { Reikš- } \\
\text { mingu- } \\
\text { mas, } q_{i}\end{array}$} & \multicolumn{2}{|c|}{ Nagrinejjami projektai } \\
\hline & & & & $2007 \mathrm{~m}$. & $2009 \mathrm{~m}$. \\
\hline 1 & 2 & 3 & 4 & 5 & 6 \\
\hline 1. BVP augimas/smukimas & $\%$ & + & 0,051 & 0,0287 & 0,0223 \\
\hline 2. PVM standartinis tarifas & $\%$ & - & 0,025 & 0,0122 & 0,0128 \\
\hline 3. Palūkanų normos & $\%$ & - & 0,038 & 0,0153 & 0,0227 \\
\hline $\begin{array}{l}\text { 4. Mokestinès lengvatos mokant } \\
\text { kreditą }\end{array}$ & balai $(0 / 10)$ & + & 0,038 & 0,0234 & 0,0146 \\
\hline $\begin{array}{l}\text { 5. Pasaulinis konkurencingumo } \\
\text { indeksas }\end{array}$ & vieta & - & 0,038 & 0,0176 & 0,0204 \\
\hline $\begin{array}{l}\text { 6. Vartotoju pasitikejjimo rodik- } \\
\text { lis }\end{array}$ & $\%$ & + & 0,032 & 0,0213 & 0,0107 \\
\hline $\begin{array}{l}\text { 7. Vidutinis mènesinis bruto } \\
\text { darbo užmokestis }\end{array}$ & $\mathrm{Lt}$ & + & 0,135 & 0,0631 & 0,0719 \\
\hline $\begin{array}{l}\text { 8. Realaus darbo užmokesčio } \\
\text { indeksas }\end{array}$ & $\%$ & + & 0,051 & 0,0284 & 0,0226 \\
\hline 9. Nedarbo lygis & $\%$ & - & 0,063 & 0,0124 & 0,0506 \\
\hline $\begin{array}{l}\text { 10. Korupcijos suvokimo indek- } \\
\text { sas }\end{array}$ & balai $(0 / 10)$ & + & 0,025 & 0,0124 & 0,0126 \\
\hline 11. Logistikos paslaugu lygis & balai $(1 / 5)$ & + & 0,063 & 0,0296 & 0,0334 \\
\hline $\begin{array}{l}\text { 12. Bendradarbiavimas su moks- } \\
\text { lo įstaigomis }\end{array}$ & balai & + & 0,038 & 0,0194 & 0,0186 \\
\hline $\begin{array}{l}13 \text {. Socialinès rūpybos infrast- } \\
\text { ruktūra }\end{array}$ & balai $(0 / 10)$ & + & 0,057 & 0,0263 & 0,0307 \\
\hline $\begin{array}{l}\text { 14. Sveikatos apsaugos infrast- } \\
\text { ruktūra }\end{array}$ & balai $(0 / 10)$ & + & 0,063 & 0,0336 & 0,0294 \\
\hline 15. Gyventojų amžiaus vidurkis & metai & - & 0,051 & 0,0253 & 0,057 \\
\hline 16. Vidutinè gyvenimo trukmè & metai & + & 0,051 & 0,0251 & 0,0259 \\
\hline 17. Gimstamumo lygis & $\begin{array}{l}\text { vnt./ } 1000 \\
\text { gyv. }\end{array}$ & + & 0,076 & 0,0354 & 0,0406 \\
\hline $\begin{array}{l}\text { 18. Statyboje sukuriama pridèti- } \\
\text { né verte }\end{array}$ & $\%$ & + & 0,095 & 0,0582 & 0,0368 \\
\hline 19. Statybos pasitikejjimo rodiklis & $\%$ & + & 0,114 & 0,0943 & 0,0197 \\
\hline $\begin{array}{l}\text { 20. Statybos sąnaudų kainų in- } \\
\text { deksai }\end{array}$ & $\%$ & - & 0,247 & 0,1406 & 0,1064 \\
\hline
\end{tabular}


$1 C$ lentelès pabaiga

\begin{tabular}{|c|c|c|c|c|c|}
\hline 1 & 2 & 3 & 4 & 5 & 6 \\
\hline $\begin{array}{l}\text { 21. Vidutiniškai per ketvirtị } \\
\text { išduota leidimų gyvenamųuc } \\
\text { pastatų statybai }\end{array}$ & vnt. & + & 0,095 & 0,0565 & 0,0385 \\
\hline $\begin{array}{l}\text { 22. Paskolos būstui palūkanų } \\
\text { normos }\end{array}$ & $\%$ & - & 0,146 & 0,0563 & 0,0897 \\
\hline $\begin{array}{l}\text { 23. Vidutinis ménesinis bruto } \\
\text { darbo užmokestis statyboje }\end{array}$ & $\mathrm{Lt}$ & - & 0,141 & 0,0754 & 0,0656 \\
\hline 24. Ateities lūkesčių tenkinimas & balai $(0 / 10)$ & + & 0,044 & 0,0264 & 0,0176 \\
\hline 25. Nerimas prarasti darbą & balai $(0 / 10)$ & - & 0,057 & 0,0155 & 0,0415 \\
\hline $\begin{array}{l}\text { 26. Nerimas neužtekti pajamų } \\
\text { šeimos pragyvenimui }\end{array}$ & balai $(0 / 10)$ & - & 0,063 & 0,0225 & 0,0405 \\
\hline 27. Saugumo jausmas & balai $(0 / 10)$ & + & 0,051 & 0,0272 & 0,0238 \\
\hline 28. Nelegalūs darbiniai santykiai & $\begin{array}{l}\text { rezultatyviu } \\
\text { patikrin. \% }\end{array}$ & - & 0,101 & 0,0503 & 0,0507 \\
\hline $\begin{array}{l}\text { 29. Kvalifikacijos kèlimo gali- } \\
\text { mybés }\end{array}$ & balai $(0 / 10)$ & + & 0,095 & 0,0554 & 0,0396 \\
\hline 30. Konkurentu kiekis rinkoje & vnt. & - & 0,076 & 0,032 & 0,044 \\
\hline 31. Konkurentu aktyvumas & balai $(0 / 10)$ & - & 0,095 & 0,0416 & 0,0534 \\
\hline 32. Potencialių kreditorių kiekis & vnt. & + & 0,095 & 0,047 & 0,048 \\
\hline 33. Kreditoriu galimybès & balai $(0 / 10)$ & + & 0,127 & 0,0816 & 0,0454 \\
\hline $\begin{array}{l}\text { 34. Darbuotojų etikos kodekso } \\
\text { laikymasis }\end{array}$ & balai $(0 / 10)$ & + & 0,057 & 0,0263 & 0,0307 \\
\hline 35. Darbuotojų kompetencija & balai $(0 / 10)$ & + & 0,108 & 0,0491 & 0,0589 \\
\hline 36. Darbuotoju patirtis & balai $(0 / 10)$ & + & 0,158 & 0,0729 & 0,0851 \\
\hline 37. Darbuotojų lojalumas & balai $(0 / 10)$ & + & 0,051 & 0,017 & 0,034 \\
\hline 38. Darbuotojų iniciatyvumas & balai $(0 / 10)$ & + & 0,108 & 0,036 & 0,072 \\
\hline 39. Tiekèjų terminų paisymas & balai $(0 / 10)$ & + & 0,095 & 0,0438 & 0,0512 \\
\hline 40. Tiekimu kokybès garantijos & balai $(0 / 10)$ & + & 0,114 & 0,0526 & 0,0614 \\
\hline 41. Šalių interesų derinimas & balai $(0 / 10)$ & + & 0,057 & 0,0311 & 0,0259 \\
\hline 42. Gyventojų bendrijos veikla & balai $(0 / 10)$ & + & 0,032 & 0,0171 & 0,0149 \\
\hline 43. Darbo užmokestis projekte & $\mathrm{Lt}$ & + & 0,128 & 0,0732 & 0,0548 \\
\hline 44. Medžiagos & $\mathrm{Lt}$ & + & 0,422 & 0,2252 & 0,1968 \\
\hline 45. Mechanizmai & $\mathrm{Lt}$ & + & 0,005 & 0,0029 & 0,0021 \\
\hline 46. Pridètinès išlaidos & $\mathrm{Lt}$ & + & 0,040 & 0,0234 & 0,0166 \\
\hline 47. Pelnas & $\mathrm{Lt}$ & + & 0,013 & 0,0103 & 0,0027 \\
\hline 48. PVM & $\mathrm{Lt}$ & - & 0,116 & 0,0639 & 0,0521 \\
\hline \multicolumn{4}{|c|}{ Maksimizuojančių normalizuotu ivertintų rodiklių suma $S_{+}$} & 1,4742 & 1,3098 \\
\hline \multicolumn{4}{|c|}{ Minimizuojančių normalizuotu įvertintų rodiklių suma $S_{-j}$} & 0,5809 & 0,6761 \\
\hline \multicolumn{4}{|c|}{ Projekto igyvendinimo varianto reikšmingumas $Q_{j}$} & 2,0991 & 1,8907 \\
\hline \multicolumn{4}{|c|}{ Projekto igyvendinimo varianto prioritetiškumas $P_{j}$} & 1 & 2 \\
\hline \multicolumn{4}{|c|}{ Projekto igyvendinimo varianto naudingumo laipsnis $N_{j}$} & $100 \%$ & $90,07 \%$ \\
\hline
\end{tabular}




\section{D priedas. Vilos parko ir statinių rekonstrukcijos igyvendinimo daugiakriterinès analizès rezultatai}

$1 D$ lentelè. Vilos parko ir statinių rekonstrukcijos igyvendinimo daugiakriterinès analizès rezultatai

Table 1D. Results of the Multiple Criteria Analysis of Restoration of the Manor (Park and Buildings)

\begin{tabular}{|c|c|c|c|c|c|c|c|}
\hline \multirow[b]{2}{*}{ Nagrinèjami kriterijai } & \multirow[b]{2}{*}{$\begin{array}{l}\text { Mato } \\
\text { vienetai }\end{array}$} & \multirow{2}{*}{$\begin{array}{l}\text { Min } \\
\text { ar } \\
\max \end{array}$} & \multirow{2}{*}{$\begin{array}{l}\text { Reikš- } \\
\text { min- } \\
\text { gumas, } \\
q_{i} \\
\end{array}$} & \multicolumn{4}{|c|}{ Nagrinejami projektai } \\
\hline & & & & $\begin{array}{l}2007 \\
\mathrm{~m} .\end{array}$ & $\begin{array}{c}2008 \\
\mathrm{~m} .\end{array}$ & $\begin{array}{l}2009 \\
\mathrm{~m} .\end{array}$ & $\begin{array}{l}2010 \\
\mathrm{~m} .\end{array}$ \\
\hline 1 & 2 & 3 & 4 & 5 & 6 & 7 & 8 \\
\hline $\begin{array}{l}\text { 1. BVP augi- } \\
\text { mas/smukimas }\end{array}$ & $\%$ & + & 0,052 & 0,0143 & 0,0134 & 0,0111 & 0,0132 \\
\hline $\begin{array}{l}\text { 2. PVM standartinis } \\
\text { tarifas }\end{array}$ & $\%$ & - & 0,041 & 0,0097 & 0,0097 & 0,0102 & 0,0113 \\
\hline 3. Palūkanų normos & $\%$ & - & 0,047 & 0,0106 & 0,0114 & 0,0157 & 0,0093 \\
\hline $\begin{array}{l}\text { 4. Mokestinès lengvatos } \\
\text { ükio subjektams }\end{array}$ & $\begin{array}{l}\text { balai } \\
(0 / 10)\end{array}$ & + & 0,052 & 0,0160 & 0,0140 & 0,0120 & 0,0100 \\
\hline $\begin{array}{l}\text { 5. Pasaulinis konkuren- } \\
\text { cingumo indeksas }\end{array}$ & vieta & - & 0,026 & 0,0057 & 0,0065 & 0,0067 & 0,0071 \\
\hline $\begin{array}{l}\text { 6. Vartotoju pasitikèji- } \\
\text { mo rodiklis }\end{array}$ & $\%$ & + & 0,031 & 0,0107 & 0,0080 & 0,0054 & 0,0069 \\
\hline $\begin{array}{l}\text { 7. Vidutinis mėnesinis } \\
\text { bruto darbo užmokestis }\end{array}$ & $\mathrm{Lt}$ & + & 0,188 & 0,0424 & 0,0506 & 0,0484 & 0,0465 \\
\hline $\begin{array}{l}\text { 8. Realaus darbo užmo- } \\
\text { kesčio indeksas }\end{array}$ & $\%$ & + & 0,052 & 0,0146 & 0,0138 & 0,0116 & 0,0120 \\
\hline 9. Nedarbo lygis & $\%$ & - & 0,041 & 0,0039 & 0,0052 & 0,0159 & 0,0160 \\
\hline $\begin{array}{l}\text { 10. Teritorijų planavimo } \\
\text { išbaigtumas }\end{array}$ & $\begin{array}{l}\text { balai } \\
(0 / 10)\end{array}$ & + & 0,052 & 0,0100 & 0,0120 & 0,0140 & 0,0160 \\
\hline $\begin{array}{l}\text { 11. Korupcijos suvokimo } \\
\text { indeksas }\end{array}$ & $\begin{array}{l}\text { balai } \\
(0 / 10)\end{array}$ & + & 0,041 & 0,0102 & 0,0098 & 0,0104 & 0,0106 \\
\hline 12. Verslumo lygis & $\begin{array}{l}\text { im. vnt./ } \\
1000 \\
\text { gyv. }\end{array}$ & + & 0,047 & 0,0110 & 0,0118 & 0,0122 & 0,0120 \\
\hline $\begin{array}{l}\text { 13. Logistikos paslaugų } \\
\text { dalis bendroje pridettinejje } \\
\text { verteje }\end{array}$ & $\%$ & + & 0,052 & 0,0123 & 0,0117 & 0,0133 & 0,0147 \\
\hline $\begin{array}{l}\text { 14. Bendradarbiavimas su } \\
\text { mokslo istaigomis }\end{array}$ & balai & + & 0,041 & 0,0105 & 0,0100 & 0,0101 & 0,0105 \\
\hline $\begin{array}{l}\text { 15. Aukštujų technologijų } \\
\text { produkcijos dalis eksporte }\end{array}$ & $\%$ & + & 0,031 & 0,0059 & 0,0076 & 0,0085 & 0,0091 \\
\hline $\begin{array}{l}\text { 16. Kultūros infrastruktū- } \\
\text { ra }\end{array}$ & $\begin{array}{l}\text { balai } \\
(0 / 10)\end{array}$ & + & 0,052 & 0,0130 & 0,0149 & 0,0130 & 0,0111 \\
\hline $\begin{array}{l}\text { 17. Socialinès rūpybos } \\
\text { infrastruktūra }\end{array}$ & $\begin{array}{l}\text { balai } \\
(0 / 10)\end{array}$ & + & 0,041 & 0,0098 & 0,0115 & 0,0098 & 0,0098 \\
\hline
\end{tabular}


$1 D$ lentelès tesinys

\begin{tabular}{|c|c|c|c|c|c|c|c|}
\hline 1 & 2 & 3 & 4 & 5 & 6 & 7 & 8 \\
\hline $\begin{array}{l}\text { 18. Sveikatos apsaugos } \\
\text { infrastruktūra }\end{array}$ & $\begin{array}{l}\text { balai } \\
(0 / 10)\end{array}$ & + & 0,052 & 0,0154 & 0,0135 & 0,0116 & 0,0116 \\
\hline $\begin{array}{l}\text { 19. Gyventojų amžiaus } \\
\text { vidurkis }\end{array}$ & metai & - & 0,036 & 0,0089 & 0,0090 & 0,0090 & 0,0091 \\
\hline 20. Gimstamumo lygis & $\begin{array}{l}\text { vnt./ } \\
1000 \\
\text { gyv. }\end{array}$ & + & 0,041 & 0,0096 & 0,0105 & 0,0110 & 0,0100 \\
\hline $\begin{array}{l}\text { 21. Statyboje sukuriama } \\
\text { pridètinè verte }\end{array}$ & $\%$ & + & 0,073 & 0,0230 & 0,0225 & 0,0146 & 0,0130 \\
\hline $\begin{array}{l}\text { 22. Statybos pasitikèjimo } \\
\text { rodiklis }\end{array}$ & $\%$ & + & 0,083 & 0,0335 & 0,0239 & 0,0070 & 0,0185 \\
\hline $\begin{array}{l}\text { 23. Statybos sąnaudų } \\
\text { kainų indeksai }\end{array}$ & $\%$ & - & 0,135 & 0,0386 & 0,0336 & 0,0292 & 0,0336 \\
\hline $\begin{array}{l}\text { 24. Vidutiniškai per ket- } \\
\text { virtị išduota leidimų ne- } \\
\text { gyvenamuju pastatų sta- } \\
\text { tybai }\end{array}$ & vnt. & + & 0,041 & 0,0117 & 0,0113 & 0,0103 & 0,0078 \\
\hline $\begin{array}{l}25 \text {. Vidutinis ménesinis } \\
\text { bruto darbo užmokestis } \\
\text { statyboje }\end{array}$ & $\mathrm{Lt}$ & - & 0,190 & 0,0504 & 0,0556 & 0,0438 & 0,0402 \\
\hline $\begin{array}{l}\text { 26. Ateities lūkesčių } \\
\text { tenkinimas }\end{array}$ & $\begin{array}{l}\text { balai } \\
(0 / 10)\end{array}$ & + & 0,047 & 0,0176 & 0,0078 & 0,0098 & 0,0118 \\
\hline $\begin{array}{l}\text { 27. Nerimas prarasti } \\
\text { darbą }\end{array}$ & $\begin{array}{l}\text { balai } \\
(0 / 10)\end{array}$ & - & 0,036 & 0,0040 & 0,0120 & 0,0107 & 0,0093 \\
\hline $\begin{array}{l}\text { 28. Nerimas neužtekti } \\
\text { pajamų pragyvenimui }\end{array}$ & $\begin{array}{l}\text { balai } \\
(0 / 10)\end{array}$ & - & 0,035 & 0,0067 & 0,0108 & 0,0094 & 0,0081 \\
\hline 29. Saugumo jausmas & $\begin{array}{l}\text { balai } \\
(0 / 10)\end{array}$ & + & 0,031 & 0,0095 & 0,0072 & 0,0083 & 0,006 \\
\hline $\begin{array}{l}\text { 30. Nelegalūs darbiniai } \\
\text { santykiai }\end{array}$ & $\begin{array}{l}\text { rezultaty- } \\
\text { vių patik- } \\
\text { rinimu \% }\end{array}$ & - & 0,073 & 0,0181 & 0,0191 & 0,0183 & 0,0174 \\
\hline $\begin{array}{l}\text { 31. Kvalifikacijos kèlimo } \\
\text { galimybès }\end{array}$ & $\begin{array}{l}\text { balai } \\
(0 / 10)\end{array}$ & + & 0,104 & 0,0331 & 0,0189 & 0,0236 & 0,0284 \\
\hline $\begin{array}{l}\text { 32. Konkurentų kiekis } \\
\text { rinkoje }\end{array}$ & vnt. & - & 0,041 & 0,0086 & 0,009 & 0,0118 & 0,0108 \\
\hline $\begin{array}{l}\text { 33. Konkurentų aktyvu- } \\
\text { mas }\end{array}$ & $\begin{array}{c}\text { balai } \\
(0 / 10)\end{array}$ & - & 0,062 & 0,0100 & 0,0160 & 0,0180 & 0,0180 \\
\hline $\begin{array}{l}\text { 34. Potencialių kreditoriu } \\
\text { kiekis }\end{array}$ & vnt. & + & 0,083 & 0,0205 & 0,0232 & 0,021 & 0,0183 \\
\hline 35. Kreditorių galimybès & $\begin{array}{c}\text { balai } \\
(0 / 10)\end{array}$ & + & 0,114 & 0,0428 & 0,0332 & 0,0142 & 0,0238 \\
\hline $\begin{array}{l}\text { 36. Darbuotoju etikos } \\
\text { kodekso laikymasis }\end{array}$ & $\begin{array}{l}\text { balai } \\
(0 / 10)\end{array}$ & + & 0,062 & 0,0149 & 0,0124 & 0,0174 & 0,0174 \\
\hline $\begin{array}{l}\text { 37. Darbuotojų kompe- } \\
\text { tencija }\end{array}$ & $\begin{array}{l}\text { balai } \\
(0 / 10)\end{array}$ & + & 0,166 & 0,0361 & 0,0361 & 0,0433 & 0,0505 \\
\hline
\end{tabular}


$1 D$ lentelès pabaiga

\begin{tabular}{|c|c|c|c|c|c|c|c|}
\hline 1 & 2 & 3 & 4 & 5 & 6 & 7 & 8 \\
\hline 38. Darbuotojų patirtis & $\begin{array}{l}\text { balai } \\
(0 / 10)\end{array}$ & + & 0,218 & 0,0503 & 0,0503 & 0,0587 & 0,0587 \\
\hline 39. Darbuotojų lojalumas & $\begin{array}{l}\text { balai } \\
(0 / 10)\end{array}$ & + & 0,083 & 0,0119 & 0,0198 & 0,0237 & 0,0277 \\
\hline $\begin{array}{l}\text { 40. Darbuotojų iniciaty- } \\
\text { vumas }\end{array}$ & $\begin{array}{l}\text { balai } \\
(0 / 10)\end{array}$ & + & 0,093 & 0,0140 & 0,0232 & 0,0279 & 0,0279 \\
\hline 41. Terminų paisymas & $\begin{array}{l}\text { balai } \\
(0 / 10)\end{array}$ & + & 0,114 & 0,0236 & 0,0275 & 0,0314 & 0,0314 \\
\hline $\begin{array}{l}\text { 42. Tiekimų kokybès } \\
\text { garantijos }\end{array}$ & $\begin{array}{l}\text { balai } \\
(0 / 10)\end{array}$ & + & 0,135 & 0,0312 & 0,0312 & 0,0363 & 0,0363 \\
\hline $\begin{array}{l}\text { 43. Šalių interesų derini- } \\
\text { mas }\end{array}$ & $\begin{array}{c}\text { balai } \\
(0 / 10)\end{array}$ & + & 0,093 & 0,0279 & 0,0232 & 0,0232 & 0,0186 \\
\hline 44. Darbo užmokestis & $\mathrm{Lt}$ & + & 0,197 & 0,0492 & 0,0492 & 0,0492 & 0,0492 \\
\hline 45. Medžiagos & $\mathrm{Lt}$ & + & 0,184 & 0,0494 & 0,0489 & 0,0395 & 0,0461 \\
\hline 46. Mechanizmai & $\mathrm{Lt}$ & + & 0,012 & 0,0041 & 0,004 & 0,0032 & 0,0007 \\
\hline 47. Pridètinès išlai & $\mathrm{Lt}$ & + & 0,101 & 0,0274 & 0,0273 & 0,0247 & 0,0217 \\
\hline 48. Pelnas & $\mathrm{Lt}$ & + & 0,029 & 0,0101 & 0,0101 & 0,0088 & 0 \\
\hline 49. PVM & $\mathrm{Lt}$ & - & 0,099 & 0,0253 & 0,0251 & 0,0239 & 0,0247 \\
\hline \multicolumn{4}{|c|}{$\begin{array}{l}\text { Maksimizuojančių normalizuotų ivertintų rodiklių suma } \\
S_{+j}\end{array}$} & 0,79 & 0,77 &, 7423 & 7580 \\
\hline \multicolumn{4}{|c|}{ Minimizuojančių normalizuotu ivertintų rodiklių suma $S_{-j}$} & 0,1501 & 0,1683 & 0,1788 & 0,1747 \\
\hline \multicolumn{4}{|c|}{ Lèšų issisavinimo varianto reikšmingumas $Q_{j}$} & 0,9651 & 0,9381 & 0,8973 & 0,9188 \\
\hline \multicolumn{4}{|c|}{ Lèšų issisavinimo varianto prioritetiškumas $P_{j}$} & 1 & 2 & 4 & 3 \\
\hline \multicolumn{4}{|c|}{ Lèšu ỉsisavinimo varianto naudingumo laipsnis $N_{j}$} & $100 \%$ & $97,20 \%$ & $92,97 \%$ & $95,20 \%$ \\
\hline
\end{tabular}




\section{E priedas. Pakruojo dvaro sodybos restauravimo projekto duomenys}
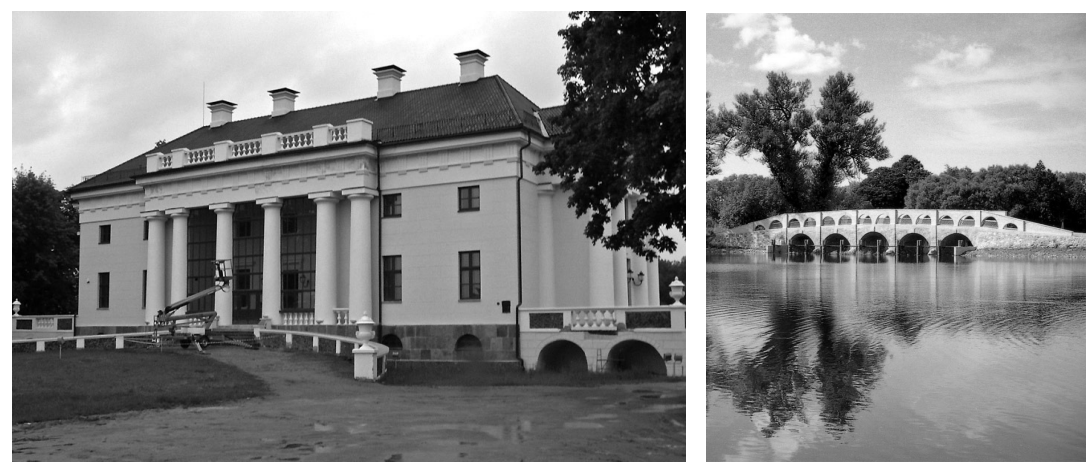

1E pav. Pakruojo dvaro sodyba

Fig. 1E. Pakruojis Manor

Statybos darbų sutartis apima 2008-2009 metus. Joje numatytų darbų vertè siekia 10,22 milijono litų. Dèl įkainių korekcijos iš tikro buvo isisavinta apie 10,08 milijono litų.

Restauruojant dvaro sodyba, buvo atlikti tokie darbai:

- 2008 metais - malūnininko namo, vandens ir vejjo malūnų, karčemos restauravimo darbai, lauko inžineriniai tinklai;

- 2009 metais - baigiamieji apdailos darbai, teritorijos sutvarkymas.

$1 E$ lentelè. Pakruojo dvaro sodybos restauravimo projekto sąmatiniai duomenys, Lt Table 1E. Restoration of the Pakruojis Manor, LTL

\begin{tabular}{|l|c|c|c|c|c|}
\hline & 2008 & 2009 & Iš viso & Pagal sutarti & Negauta \\
\hline $\begin{array}{l}\text { Darbo užmo- } \\
\text { kestis }\end{array}$ & 1927833,95 & 415822,91 & 2343656,86 & 2383782,57 & 40125,71 \\
\hline Medžiagos & 2401962,18 & 542377,79 & 2944339,97 & 2962128,99 & 17789,02 \\
\hline Mechanizmai & 298020,00 & 73480,00 & 371500,00 & 373202,00 & 1702 \\
\hline $\begin{array}{l}\text { Papildomas } \\
\text { darbo užmo- } \\
\text { kestis }\end{array}$ & 154226,72 & 43390,22 & 197616,94 & 190702,61 & $-6914,33$ \\
\hline $\begin{array}{l}\text { Socialinis } \\
\text { draudimas }\end{array}$ & 645438,81 & 142356,07 & 787794,88 & 798090,41 & 10295,53 \\
\hline $\begin{array}{l}\text { Statybvietės } \\
\text { išlaidos }\end{array}$ & 434198,53 & 94930,71 & 529129,24 & 536632,53 & 7503,29 \\
\hline $\begin{array}{l}\text { Pridètinės } \\
\text { išlaidos }\end{array}$ & 812003,66 & 177617,09 & 989620,75 & 1004049,22 & 14428,47 \\
\hline Pelnas & 333684,19 & 25960,50 & 359644,69 & 412428,62 & 52783,93 \\
\hline PVM & 1261326,25 & 291990,69 & 1553316,94 & 1558983,05 & 5666,11 \\
\hline Iš viso & 8268694,29 & 1807925,98 & 10076620,27 & 10220000,00 & 143379,73 \\
\hline
\end{tabular}


2E lentelè. Pakruojo dvaro sodybos restauravimo igyvendinimo daugiakriterinės analizès rezultatai

Table 2E. Results of the Multiple Criteria Analysis of Restoration of the Pakruojis Manor

\begin{tabular}{|c|c|c|c|c|c|}
\hline \multirow[t]{2}{*}{ Nagrinejjami kriterijai } & \multirow{2}{*}{$\begin{array}{l}\text { Mato } \\
\text { vienetai }\end{array}$} & \multirow{2}{*}{$\begin{array}{l}\text { Min } \\
\text { ar } \\
\text { max }\end{array}$} & \multirow{2}{*}{$\begin{array}{l}\text { Reikš- } \\
\text { mingu- } \\
\text { mas, } q_{i}\end{array}$} & \multicolumn{2}{|c|}{$\begin{array}{l}\text { Nagrinejami } \\
\text { projektai }\end{array}$} \\
\hline & & & & $2008 \mathrm{~m}$. & $2010 \mathrm{~m}$. \\
\hline 1 & 2 & 3 & 4 & 5 & 6 \\
\hline 1. BVP augimas/smukimas & $\%$ & + & 0,052 & 0,0284 & 0,0236 \\
\hline 2. PVM standartinis tarifas & $\%$ & - & 0,042 & 0,0204 & 0,0216 \\
\hline 3. Palūkanų normos & $\%$ & - & 0,047 & 0,0198 & 0,0272 \\
\hline $\begin{array}{l}\text { 4. Mokestinès lengvatos ūkio subjek- } \\
\text { tams }\end{array}$ & $\begin{array}{c}\text { balai } \\
(0 / 10)\end{array}$ & + & 0,052 & 0,028 & 0,024 \\
\hline $\begin{array}{l}\text { 5. Pasaulinis konkurencingumo } \\
\text { indeksas }\end{array}$ & vieta & - & 0,026 & 0,0129 & 0,0131 \\
\hline 6. Vartotojų pasitikejjimo rodiklis & $\%$ & + & 0,031 & 0,0186 & 0,0124 \\
\hline $\begin{array}{l}\text { 7. Vidutinis mènesinis bruto darbo } \\
\text { užmokestis }\end{array}$ & $\mathrm{Lt}$ & + & 0,199 & 0,1018 & 0,0972 \\
\hline $\begin{array}{l}\text { 8. Realaus darbo užmokesčio indek- } \\
\text { sas }\end{array}$ & $\%$ & + & 0,052 & 0,0282 & 0,0238 \\
\hline 9. Nedarbo lygis & $\%$ & - & 0,042 & 0,0104 & 0,0316 \\
\hline 10. Teritoriju planavimo išbaigtumas & $\begin{array}{c}\text { balai } \\
(0 / 10)\end{array}$ & + & 0,052 & 0,024 & 0,028 \\
\hline 11. Korupcijos suvokimo indeksas & $\begin{array}{l}\text { balai } \\
(0 / 10)\end{array}$ & + & 0,042 & 0,0203 & 0,0217 \\
\hline 12. Verslumo lygis & $\begin{array}{l}\text { im. vnt./ } \\
1000 \text { gyv. }\end{array}$ & + & 0,047 & 0,0231 & 0,0239 \\
\hline $\begin{array}{l}\text { 13. Logistikos paslaugu dalis bendroje } \\
\text { pridetineje verteje }\end{array}$ & $\%$ & + & 0,052 & 0,0244 & 0,0276 \\
\hline $\begin{array}{l}\text { 14. Bendradarbiavimas su mokslo } \\
\text { istaigomis }\end{array}$ & balai & + & 0,042 & 0,0209 & 0,0211 \\
\hline $\begin{array}{l}\text { 15. Aukštujų technologiju produkcijos } \\
\text { dalis eksporte }\end{array}$ & $\%$ & + & 0,031 & 0,0146 & 0,0164 \\
\hline 16. Kultūros infrastruktūra & $\begin{array}{c}\text { balai } \\
(0 / 10)\end{array}$ & + & 0,052 & 0,0277 & 0,0243 \\
\hline 17. Socialinès rūpybos infrastruktūra & $\begin{array}{l}\text { balai } \\
(0 / 10)\end{array}$ & + & 0,042 & 0,0226 & 0,0194 \\
\hline 18. Sveikatos apsaugos infrastruktūra & $\begin{array}{l}\text { balai } \\
(0 / 10)\end{array}$ & + & 0,052 & 0,028 & 0,024 \\
\hline 19. Gyventojų amžiaus vidurkis & metai & - & 0,042 & 0,0205 & 0,0215 \\
\hline 20. Gimstamumo lygis & $\begin{array}{l}\text { vnt./ } 1000 \\
\text { gyv. }\end{array}$ & + & 0,247 & 0,1406 & 0,1064 \\
\hline $\begin{array}{l}\text { 21. Statyboje sukuriama pridètinè } \\
\text { verté }\end{array}$ & $\%$ & + & 0,073 & 0,0443 & 0,0287 \\
\hline 22. Statybos pasitikejjimo rodiklis & $\%$ & + & 0,084 & 0,0649 & 0,0191 \\
\hline 23. Statybos sąnaudų kainų indeksai & $\%$ & - & 0,136 & 0,0727 & 0,0633 \\
\hline
\end{tabular}


$1 E$ lentelès tęsinys

\begin{tabular}{|c|c|c|c|c|c|}
\hline 1 & 2 & 3 & 4 & 5 & 6 \\
\hline $\begin{array}{l}\text { 24. Vidutiniškai per ketvirti išduota } \\
\text { leidimų negyv. pastatų statybai }\end{array}$ & vnt. & + & 0,042 & 0,022 & 0,02 \\
\hline $\begin{array}{l}\text { 25. Vidutinis mėnesinis bruto darbo } \\
\text { užmokestis statyboje }\end{array}$ & $\mathrm{Lt}$ & - & 0,201 & 0,1124 & 0,0886 \\
\hline 26. Ateities lūkesčių tenkinimas & $\begin{array}{l}\text { balai } \\
(0 / 10)\end{array}$ & + & 0,047 & 0,0209 & 0,0261 \\
\hline 27. Nerimas prarasti darbą & $\begin{array}{l}\text { balai } \\
(0 / 10)\end{array}$ & - & 0,037 & 0,0196 & 0,0174 \\
\hline $\begin{array}{l}\text { 28. Nerimas neužtekti pajamų pragy- } \\
\text { venimui }\end{array}$ & $\begin{array}{l}\text { balai } \\
(0 / 10)\end{array}$ & - & 0,037 & 0,0197 & 0,0173 \\
\hline 29. Saugumo jausmas & $\begin{array}{l}\text { balai } \\
(0 / 10)\end{array}$ & + & 0,031 & 0,0143 & 0,0167 \\
\hline 30. Nelegalūs darbiniai santykiai & $\begin{array}{l}\text { rezultaty- } \\
\text { viu patik- } \\
\text { rinimų \% }\end{array}$ & - & 0,073 & 0,0373 & 0,0357 \\
\hline 31. Kvalifikacijos kèlimo galimybės & $\begin{array}{l}\text { balai } \\
(0 / 10) \\
\end{array}$ & + & 0,105 & 0,0467 & 0,0583 \\
\hline 32. Konkurentų kiekis rinkoje & vnt. & - & 0,042 & 0,0192 & 0,0228 \\
\hline 33. Konkurentų aktyvumas & $\begin{array}{c}\text { balai } \\
(0 / 10)\end{array}$ & - & 0,063 & 0,0296 & 0,0334 \\
\hline 34. Potencialių kreditorių kiekis & vnt. & + & 0,084 & 0,0441 & 0,0399 \\
\hline 35. Kreditorių galimybès & $\begin{array}{l}\text { balai } \\
(0 / 10)\end{array}$ & + & 0,115 & 0,0805 & 0,0345 \\
\hline $\begin{array}{l}\text { 36. Darbuotojų etikos kodekso laiky- } \\
\text { masis }\end{array}$ & $\begin{array}{l}\text { balai } \\
(0 / 10)\end{array}$ & + & 0,063 & 0,0262 & 0,0368 \\
\hline 37. Darbuotojų kompetencija & $\begin{array}{l}\text { balai } \\
(0 / 10)\end{array}$ & + & 0,167 & 0,0759 & 0,0911 \\
\hline 38. Darbuotojų patirtis & $\begin{array}{l}\text { balai } \\
(0 / 10)\end{array}$ & + & 0,179 & 0,0826 & 0,0964 \\
\hline 39. Darbuotojų lojalumas & $\begin{array}{l}\text { balai } \\
(0 / 10)\end{array}$ & + & 0,084 & 0,0382 & 0,0458 \\
\hline 40. Darbuotojų iniciatyvumas & $\begin{array}{l}\text { balai } \\
(0 / 10)\end{array}$ & + & 0,094 & 0,0427 & 0,0513 \\
\hline 41. Terminų paisymas & $\begin{array}{l}\text { balai } \\
(0 / 10)\end{array}$ & + & 0,115 & 0,0537 & 0,0613 \\
\hline 42. Tiekimų kokybès garantijos & $\begin{array}{l}\text { balai } \\
(0 / 10)\end{array}$ & + & 0,136 & 0,0628 & 0,0732 \\
\hline 43. Šalių interesų derinimas & $\begin{array}{l}\text { balai } \\
(0 / 10)\end{array}$ & + & 0,094 & 0,047 & 0,047 \\
\hline 44. Darbo užmokestis & $\mathrm{Lt}$ & + & 0,199 & 0,0995 & 0,0995 \\
\hline 45. Medžiagos & $\mathrm{Lt}$ & + & 0,177 & 0,0875 & 0,0895 \\
\hline 46. Mechanizmai & $\mathrm{Lt}$ & + & 0,023 & 0,0109 & 0,0121 \\
\hline 47. Pridètinès išlaidos & $\mathrm{Lt}$ & + & 0,09 & 0,0452 & 0,0448 \\
\hline 48. Pelnas & $\mathrm{Lt}$ & + & 0,016 & 0,0118 & 0,0042 \\
\hline 49. PVM & $\mathrm{Lt}$ & - & 0,094 & 0,0459 & 0,0481 \\
\hline \multicolumn{4}{|c|}{ Maksimizuojančių normalizuotų įvertintų rodiklių suma $S_{+}$} & 1,4528 & 1,4052 \\
\hline
\end{tabular}


1 E lentelés pabaiga

\begin{tabular}{|c|c|c|c|c|c|}
\hline 1 & 2 & 3 & 4 & 5 & 6 \\
\hline \multicolumn{4}{|c|}{ Minimizuojančių normalizuotų įvertintų rodiklių suma $S_{-j}$} & 0,4384 & 0,4386 \\
\hline \multicolumn{4}{|c|}{ Projekto igyvendinimo varianto reikšmingumas $Q_{j}$} & 1,8913 & 1,8436 \\
\hline \multicolumn{4}{|c|}{ Projekto igyvendinimo varianto prioritetiškumas $P_{j}$} & 1 & 2 \\
\hline \multicolumn{4}{|c|}{ Projekto igyvendinimo varianto naudingumo laipsnis $N_{j}$} & $100 \%$ & $97,48 \%$ \\
\hline
\end{tabular}




\section{F priedas. Devynaukščių namų modernizavimo projektų duomenys}

Vienas projektas igyvendintas 2008 metais (adresas Grinkevičiaus g. 4, Šiauliai) ir apima devynaukščio namo (108 butai) apšiltinimą:

- langų keitimas;

- lauko durų keitimas;

- fasadinių sienų šiltinimas;

- cokolio šiltinimas.

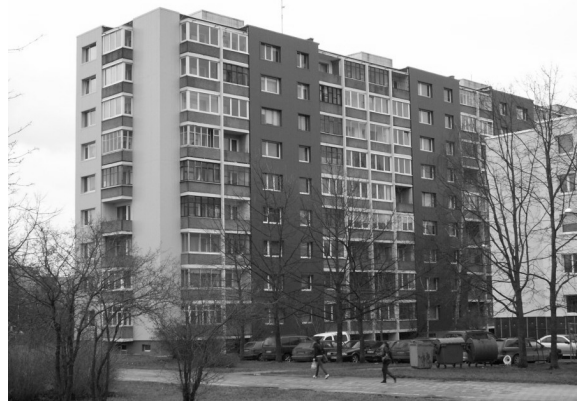

1F pav. Devynaukštis Grinkevičiaus g. 4, Šiauliai

Fig. 1F. The Nine-Storey Apartment Grinkevičiaus Street 4, Šiauliai

Antrasis igyvendintas 2010 metais (adresas Aido g. 17, Šiauliai). Apšiltintas 54 butų devynaukštis:

- langu keitimas;

- balkonų (lodžijų) istiklinimas pagal vieną projektą;

- fasadinių sienų šiltinimas;

- cokolio šiltinimas.

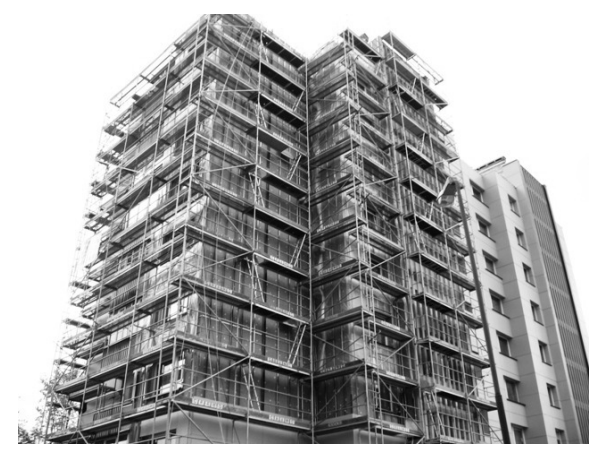

2F pav. Devynaukštis Aido g. 17, Šiauliai

Fig. 2F. The Nine-Storey Apartment Aido Street 17, šiauliai 
1F lentelè. Devynaukščių namų modernizavimo projektų igyvendinimas, Lt

Table 1F. Implementation of Refurbishment Projects for Nine-Storey Apartment Buildings, LTL

\begin{tabular}{|l|c|c|}
\hline & 2008 & 2010 \\
\hline Darbo užmokestis & 245684,54 & 105509,54 \\
\hline Medžiagos & 670269,81 & 339582,25 \\
\hline Mechanizmai & 46750,71 & 1684,81 \\
\hline Papildomas darbo užmokestis & 19654,76 & 2110,19 \\
\hline Socialinis draudimas & 82255,18 & 33362,12 \\
\hline Statybvietės išlaidos & 106461,50 & 9644,98 \\
\hline Pridètinės išlaidos & 106135,72 & 9685,78 \\
\hline Pelnas & 63860,61 & 5015,8 \\
\hline PVM & 241393,11 & 106385,05 \\
\hline Iš viso & 1582465,94 & 612980,52 \\
\hline
\end{tabular}

2F lentelė. Devynaukščių namų modernizavimo projektų igyvendinimo variantų daugiakriterinès analizès rezultatai (įmonès požiūriu)

Table 2F. Results of the Multiple Criteria Analysis of Refurbishment Project Variants for nine-storey Apartment Buildings (Company Approach)

\begin{tabular}{|c|c|c|c|c|c|}
\hline \multirow{2}{*}{ Nagrinèjami kriterijai } & \multirow{2}{*}{$\begin{array}{l}\text { Mato } \\
\text { vienetai }\end{array}$} & \multirow{2}{*}{$\begin{array}{l}\text { Min } \\
\text { ar } \\
\max \end{array}$} & \multirow{2}{*}{$\begin{array}{l}\text { Reikš- } \\
\text { mingu- } \\
\text { mas, } q_{i}\end{array}$} & \multicolumn{2}{|c|}{ Nagrinejami projektai } \\
\hline & & & & $2008 \mathrm{~m}$. & $2010 \mathrm{~m}$. \\
\hline 1 & 2 & 3 & 4 & 5 & 6 \\
\hline 1. BVP augimas/smukimas & $\%$ & + & 0,035 & 0,0176 & 0,0174 \\
\hline 2. PVM standartinis tarifas & $\%$ & - & 0,017 & 0,0078 & 0,0092 \\
\hline 3. Palūkanų normos & $\%$ & - & 0,043 & 0,0237 & 0,0193 \\
\hline $\begin{array}{l}\text { 4. Mokestinès lengvatos mokant } \\
\text { kreditą }\end{array}$ & $\begin{array}{l}\text { balai } \\
(0 / 10)\end{array}$ & + & 0,026 & 0,0142 & 0,0118 \\
\hline $\begin{array}{l}\text { 5. Pasaulinis konkurencingumo } \\
\text { indeksas }\end{array}$ & vieta & - & 0,020 & 0,0096 & 0,0104 \\
\hline 6. Vartotojų pasitikejjimo rodiklis & $\%$ & + & 0,022 & 0,0118 & 0,0102 \\
\hline $\begin{array}{l}\text { 7. Vidutinis mènesinis bruto } \\
\text { darbo užmokestis }\end{array}$ & $\mathrm{Lt}$ & + & 0,020 & 0,0104 & 0,0096 \\
\hline $\begin{array}{l}\text { 8. Realaus darbo užmokesčio } \\
\text { indeksas }\end{array}$ & $\%$ & + & 0,035 & 0,0187 & 0,0163 \\
\hline 9. Nedarbo lygis & $\%$ & - & 0,043 & 0,0106 & 0,0324 \\
\hline 10. Korupcijos suvokimo indeksas & $\begin{array}{l}\text { balai } \\
(0 / 10)\end{array}$ & + & 0,017 & 0,0081 & 0,0089 \\
\hline 11. Logistikos paslaugų lygis & $\begin{array}{l}\text { balai } \\
(1 / 5)\end{array}$ & + & 0,043 & 0,0202 & 0,0228 \\
\hline $\begin{array}{l}\text { 12. Bendradarbiavimas su mokslo } \\
\text { istaigomis }\end{array}$ & balai & + & 0,026 & 0,0126 & 0,0134 \\
\hline $\begin{array}{l}\text { 13. Socialinès rūpybos infrastruk- } \\
\text { tūra }\end{array}$ & $\begin{array}{l}\text { balai } \\
(0 / 10)\end{array}$ & + & 0,039 & 0,0228 & 0,0162 \\
\hline $\begin{array}{l}\text { 14. Sveikatos apsaugos infrastruk- } \\
\text { tūra }\end{array}$ & $\begin{array}{l}\text { balai } \\
(0 / 10)\end{array}$ & + & 0,043 & 0,0251 & 0,0179 \\
\hline 15. Gyventojų amžiaus vidurkis & metai & - & 0,035 & 0,0174 & 0,0176 \\
\hline
\end{tabular}


$2 F$ lentelès tęsinys

\begin{tabular}{|c|c|c|c|c|c|}
\hline 1 & 2 & 3 & 4 & 5 & 6 \\
\hline 16. Vidutinè gyvenimo trukmè & metai & + & 0,035 & 0,0171 & 0,0179 \\
\hline 17. Gimstamumo lygis & $\begin{array}{l}\text { vnt./ } 1000 \\
\text { gyventojų }\end{array}$ & + & 0,052 & 0,0266 & 0,0254 \\
\hline $\begin{array}{l}\text { 18. Statyboje sukuriama pridètinè } \\
\text { verté }\end{array}$ & $\%$ & + & 0,065 & 0,0406 & 0,0244 \\
\hline 19. Statybos pasitikejjimo rodiklis & $\%$ & + & 0,078 & 0,0440 & 0,0340 \\
\hline $\begin{array}{l}\text { 20. Statybos sąnaudu kainų indek- } \\
\text { sai }\end{array}$ & $\%$ & - & 0,169 & 0,0844 & 0,0846 \\
\hline $\begin{array}{l}\text { 21. Vidutiniškai per ketvirtị išduo- } \\
\text { ta leidimų gyvenamųu pastatų } \\
\text { statybai }\end{array}$ & vnt. & + & 0,065 & 0,0386 & 0,0264 \\
\hline $\begin{array}{l}\text { 22. Paskolos būstui palūkanų } \\
\text { normos }\end{array}$ & $\%$ & - & 0,1 & 0,0551 & 0,0449 \\
\hline $\begin{array}{l}\text { 23. Vidutinis mènesinis bruto } \\
\text { darbo užmokestis statyboje }\end{array}$ & $\mathrm{Lt}$ & - & 0,198 & 0,1149 & 0,0831 \\
\hline 24. Nerimas prarasti darbą & $\begin{array}{l}\text { balai } \\
(0 / 10)\end{array}$ & - & 0,039 & 0,0219 & 0,0171 \\
\hline $\begin{array}{l}\text { 25. Nerimas neužtekti pajamų } \\
\text { šeimos pragyvenimui }\end{array}$ & $\begin{array}{l}\text { balai } \\
(0 / 10)\end{array}$ & - & 0,043 & 0,0246 & 0,0184 \\
\hline 26. Saugumo jausmas & $\begin{array}{l}\text { balai } \\
(0 / 10)\end{array}$ & + & 0,035 & 0,0191 & 0,0159 \\
\hline 27. Nelegalūs darbiniai santykiai & $\begin{array}{c}\text { rezultatyvių } \\
\text { patikrinimu } \\
\% \\
\end{array}$ & - & 0,069 & 0,0361 & 0,0329 \\
\hline $\begin{array}{l}\text { 28. Kvalifikacijos kèlimo galimy- } \\
\text { bès }\end{array}$ & $\begin{array}{c}\text { balai } \\
(0 / 10)\end{array}$ & + & 0,065 & 0,026 & 0,039 \\
\hline 29. Konkurentu kiekis rinkoje & vnt. & - & 0,052 & 0,0248 & 0,0272 \\
\hline 30. Konkurentų aktyvumas & $\begin{array}{l}\text { balai } \\
(0 / 10)\end{array}$ & - & 0,065 & 0,0306 & 0,0344 \\
\hline 31. Potencialių kreditorių kiekis & vnt. & + & 0,065 & 0,0363 & 0,0287 \\
\hline 32. Kreditoriu galimybės & $\begin{array}{l}\text { balai } \\
(0 / 10)\end{array}$ & + & 0,087 & 0,0507 & 0,0362 \\
\hline $\begin{array}{l}\text { 33. Darbuotojų etikos kodekso } \\
\text { laikymasis }\end{array}$ & $\begin{array}{l}\text { balai } \\
(0 / 10)\end{array}$ & + & 0,039 & 0,0162 & 0,0228 \\
\hline 34. Darbuotojų kompetencija & $\begin{array}{l}\text { balai } \\
(0 / 10)\end{array}$ & + & 0,074 & 0,0308 & 0,0432 \\
\hline 35. Darbuotojų patirtis & $\begin{array}{l}\text { balai } \\
(0 / 10)\end{array}$ & + & 0,108 & 0,0498 & 0,0582 \\
\hline 36. Darbuotojų lojalumas & $\begin{array}{l}\text { balai } \\
(0 / 10)\end{array}$ & + & 0,035 & 0,0146 & 0,0204 \\
\hline 37. Darbuotojų iniciatyvumas & $\begin{array}{l}\text { balai } \\
(0 / 10)\end{array}$ & + & 0,074 & 0,0336 & 0,0404 \\
\hline 38. Tiekèjų terminų paisymas & $\begin{array}{l}\text { balai } \\
(0 / 10)\end{array}$ & + & 0,065 & 0,0303 & 0,0347 \\
\hline 39. Tiekimų kokybės garantijos & $\begin{array}{l}\text { balai } \\
(0 / 10)\end{array}$ & + & 0,078 & 0,036 & 0,042 \\
\hline
\end{tabular}


$2 F$ lentelès pabaiga

\begin{tabular}{|l|c|c|c|c|c|}
\hline \multicolumn{1}{|c|}{1} & 2 & 3 & 4 & 5 & 6 \\
\hline 40. Šalių interesų derinimas & $\begin{array}{c}\text { balai } \\
(0 / 10)\end{array}$ & + & 0,039 & 0,0217 & 0,0173 \\
\hline 41. Gyventojų bendrijos veikla & $\begin{array}{c}\text { balai } \\
(0 / 10)\end{array}$ & + & 0,022 & 0,0118 & 0,0102 \\
\hline 42. Darbo užmokestis projekte & $\mathrm{Lt}$ & + & 0,135 & 0,0745 & 0,0605 \\
\hline 43. Medžiagos & $\mathrm{Lt}$ & + & 0,298 & 0,1435 & 0,1455 \\
\hline 44. Mechanizmai & $\mathrm{Lt}$ & + & 0,011 & 0,0103 & 0,0007 \\
\hline 45. Pridètinės išlaidos & $\mathrm{Lt}$ & + & 0,054 & 0,0457 & 0,0083 \\
\hline 46. Pelnas & $\mathrm{Lt}$ & + & 0,016 & 0,0138 & 0,0022 \\
\hline 47. PVM & $\mathrm{Lt}$ & - & 0,097 & 0,0516 & 0,0454 \\
\hline Maksimizuojančių normalizuotų ivertintų rodiklių suma $S_{+j}$ & 0,9931 & 0,8988 \\
\hline Minimizuojančių normalizuotu ịvertintų rodiklių suma $S_{-j}$ & & 0,5131 & 0,4769 \\
\hline Projekto igyvendinimo varianto reikšmingumas $Q_{j}$ & 1,4874 & 1,4119 \\
\hline
\end{tabular}

3F lentelè. Devynaukščių namų modernizavimo projektų igyvendinimo variantų daugiakriterinès analizès rezultatai (investuotojo požiūriu)

Table 3F. Results of the Multiple Criteria Analysis of Refurbishment Project Variants for nine-storey Apartment Buildings (Investor's Approach)

\begin{tabular}{|c|c|c|c|c|c|}
\hline \multirow{2}{*}{ Nagrinèjami kriterijai } & \multirow{2}{*}{$\begin{array}{c}\text { Mato } \\
\text { vienetai }\end{array}$} & \multirow{2}{*}{$\begin{array}{l}\text { Min } \\
\text { ar } \\
\max \end{array}$} & \multirow{2}{*}{$\begin{array}{l}\text { Reikš- } \\
\text { mingu- } \\
\text { mas, } q_{i}\end{array}$} & \multicolumn{2}{|c|}{ Nagrinėjami projektai } \\
\hline & & & & $2008 \mathrm{~m}$ & $2010 \mathrm{~m}$ \\
\hline 1 & 2 & 3 & 4 & 5 & 6 \\
\hline 1. BVP augimas/smukimas & $\%$ & + & 0,016 & 0,0081 & 0,0079 \\
\hline 2. PVM standartinis tarifas & $\%$ & - & 0,022 & 0,0102 & 0,0118 \\
\hline 3. Palūkanų normos & $\%$ & - & 0,030 & 0,0165 & 0,0135 \\
\hline $\begin{array}{l}\text { 4. Mokestinès lengvatos mokant } \\
\text { kreditą }\end{array}$ & $\begin{array}{l}\text { balai } \\
(0 / 10)\end{array}$ & + & 0,035 & 0,0191 & 0,0159 \\
\hline $\begin{array}{l}\text { 5. Pasaulinis konkurencingumo } \\
\text { indeksas }\end{array}$ & vieta & - & 0,016 & 0,0076 & 0,0084 \\
\hline 6. Vartotoju pasitikejimo rodiklis & $\%$ & + & 0,016 & 0,0086 & 0,0074 \\
\hline $\begin{array}{l}\text { 7. Vidutinis mènesinis bruto } \\
\text { darbo užmokestis }\end{array}$ & $\mathrm{Lt}$ & + & 0,020 & 0,0104 & 0,0096 \\
\hline $\begin{array}{l}\text { 8. Realaus darbo užmokesčio } \\
\text { indeksas }\end{array}$ & $\%$ & + & 0,026 & 0,0139 & 0,0121 \\
\hline 9. Nedarbo lygis & $\%$ & - & 0,030 & 0,0074 & 0,0226 \\
\hline 10. Korupcijos suvokimo indeksas & $\begin{array}{l}\text { balai } \\
(0 / 10)\end{array}$ & + & 0,048 & 0,0230 & 0,0250 \\
\hline 11. Logistikos paslaugų lygis & $\begin{array}{l}\text { balai } \\
(1 / 5)\end{array}$ & + & 0,022 & 0,0103 & 0,0117 \\
\hline
\end{tabular}


$3 F$ lentelès tęsinys

\begin{tabular}{|c|c|c|c|c|c|}
\hline 1 & 2 & 3 & 4 & 5 & 6 \\
\hline $\begin{array}{l}\text { 12. Bendradarbiavimas su mokslo } \\
\text { istaigomis }\end{array}$ & balai & + & 0,030 & 0,0146 & 0,0154 \\
\hline $\begin{array}{l}\text { 13. Socialinès rūpybos infrastruk- } \\
\text { tūra }\end{array}$ & $\begin{array}{c}\text { balai } \\
(0 / 10)\end{array}$ & + & 0,026 & 0,0152 & 0,0108 \\
\hline $\begin{array}{l}\text { 14. Sveikatos apsaugos infrastruk- } \\
\text { tūra }\end{array}$ & $\begin{array}{c}\text { balai } \\
(0 / 10)\end{array}$ & + & 0,035 & 0,0204 & 0,0146 \\
\hline 15. Gyventojų amžiaus vidurkis & metai & - & 0,026 & 0,0129 & 0,0131 \\
\hline 16. Vidutinè gyvenimo trukmè & metai & + & 0,022 & 0,0107 & 0,0113 \\
\hline 17. Gimstamumo lygis & $\begin{array}{l}\text { vnt./ } 1000 \\
\text { gyventojų }\end{array}$ & + & 0,03 & 0,0154 & 0,0146 \\
\hline $\begin{array}{l}\text { 18. Statyboje sukuriama pridètinè } \\
\text { verté }\end{array}$ & $\%$ & + & 0,043 & 0,0269 & 0,0161 \\
\hline 19. Statybos pasitikejjimo rodiklis & $\%$ & + & 0,056 & 0,0316 & 0,0244 \\
\hline $\begin{array}{l}\text { 20. Statybos sąnaudų kainų indek- } \\
\text { sai }\end{array}$ & $\%$ & - & 0,095 & 0,0475 & 0,0475 \\
\hline $\begin{array}{l}\text { 21. Vidutiniškai per ketvirtį išduo- } \\
\text { ta leidimų gyvenamųjų pastatų } \\
\text { statybai }\end{array}$ & vnt. & + & 0,043 & 0,0255 & 0,0175 \\
\hline $\begin{array}{l}\text { 22. Paskolos būstui palūkanų } \\
\text { normos }\end{array}$ & $\%$ & - & 0,074 & 0,0408 & 0,0332 \\
\hline $\begin{array}{l}\text { 23. Vidutinis ménesinis bruto } \\
\text { darbo užmokestis statyboje }\end{array}$ & $\mathrm{Lt}$ & - & 0,198 & 0,1149 & 0,0831 \\
\hline 24. Ateities lūkesčių tenkinimas & $\begin{array}{l}\text { balai } \\
(0 / 10)\end{array}$ & + & 0,016 & 0,0064 & 0,0096 \\
\hline 25. Nerimas prarasti darbą & $\begin{array}{l}\text { balai } \\
(0 / 10)\end{array}$ & - & 0,022 & 0,0124 & 0,0096 \\
\hline $\begin{array}{l}\text { 26. Nerimas neužtekti pajamų } \\
\text { šeimos pragyvenimui }\end{array}$ & $\begin{array}{c}\text { balai } \\
(0 / 10)\end{array}$ & - & 0,026 & 0,0149 & 0,0111 \\
\hline 27. Saugumo jausmas & $\begin{array}{l}\text { balai } \\
(0 / 10)\end{array}$ & + & 0,013 & 0,0071 & 0,0059 \\
\hline 28. Nelegalūs darbiniai santykiai & $\begin{array}{l}\text { rezultaty- } \\
\text { vių patik- } \\
\text { rin. } \% \\
\end{array}$ & - & 0,043 & 0,0225 & 0,0205 \\
\hline $\begin{array}{l}\text { 29. Kvalifikacijos kèlimo galimy- } \\
\text { bės }\end{array}$ & $\begin{array}{l}\text { balai } \\
(0 / 10)\end{array}$ & + & 0,061 & 0,0244 & 0,0366 \\
\hline 30. Konkurentu kiekis rinkoje & vnt. & - & 0,052 & 0,0248 & 0,0272 \\
\hline 31. Konkurentų aktyvumas & $\begin{array}{c}\text { balai } \\
(0 / 10)\end{array}$ & - & 0,074 & 0,0348 & 0,0392 \\
\hline 32. Potencialių kreditorių kiekis & vnt. & + & 0,048 & 0,0268 & 0,0212 \\
\hline 33. Kreditoriu galimybès & $\begin{array}{c}\text { balai } \\
(0 / 10)\end{array}$ & + & 0,061 & 0,0356 & 0,0254 \\
\hline $\begin{array}{l}\text { 34. Darbuotojų etikos kodekso } \\
\text { laikymasis }\end{array}$ & $\begin{array}{c}\text { balai } \\
(0 / 10)\end{array}$ & + & 0,052 & 0,0217 & 0,0303 \\
\hline 35. Darbuotojų kompetencija & $\begin{array}{l}\text { balai } \\
(0 / 10)\end{array}$ & + & 0,104 & 0,0433 & 0,0607 \\
\hline
\end{tabular}


$3 F$ lentelès pabaiga

\begin{tabular}{|c|c|c|c|c|c|}
\hline 1 & 2 & 3 & 4 & 5 & 6 \\
\hline 36. Darbuotojų patirtis & $\begin{array}{c}\text { balai } \\
(0 / 10)\end{array}$ & + & 0,156 & 0,072 & 0,084 \\
\hline 37. Darbuotojų lojalumas & $\begin{array}{l}\text { balai } \\
(0 / 10)\end{array}$ & + & 0,043 & 0,0179 & 0,02514 \\
\hline 38. Darbuotojų iniciatyvumas & $\begin{array}{l}\text { balai } \\
(0 / 10)\end{array}$ & + & 0,104 & 0,0473 & 0,0567 \\
\hline 39. Tiekèjų terminų paisymas & $\begin{array}{c}\text { balai } \\
(0 / 10)\end{array}$ & + & 0,121 & 0,0565 & 0,0645 \\
\hline 40. Tiekimų kokybès garantijos & $\begin{array}{c}\text { balai } \\
(0 / 10)\end{array}$ & + & 0,113 & 0,0522 & 0,0608 \\
\hline 41. Šalių interesų derinimas & $\begin{array}{l}\text { balai } \\
(0 / 10)\end{array}$ & + & 0,052 & 0,0289 & 0,0231 \\
\hline 42. Gyventojų bendrijos veikla & $\begin{array}{l}\text { balai } \\
(0 / 10)\end{array}$ & + & 0,159 & 0,0852 & 0,0738 \\
\hline 43. Darbo užmokestis projekte & $\mathrm{Lt}$ & - & 0,289 & 0,1435 & 0,1455 \\
\hline 44. Medžiagos & $\mathrm{Lt}$ & - & 0,422 & 0,2252 & 0,1968 \\
\hline 45. Mechanizmai & $\mathrm{Lt}$ & - & 0,011 & 0,0103 & 0,0007 \\
\hline 46. Pridètinès išlaidos & $\mathrm{Lt}$ & - & 0,054 & 0,0457 & 0,0083 \\
\hline 47. Pelnas & $\mathrm{Lt}$ & - & 0,016 & 0,0138 & 0,0022 \\
\hline 48. PVM & $\mathrm{Lt}$ & - & 0,097 & 0,0516 & 0,0454 \\
\hline \multicolumn{4}{|c|}{ Maksimizuojančių normalizuotų ivertintų rodiklių suma $S_{+}$} & 0,7790 & 0,7920 \\
\hline \multicolumn{4}{|c|}{ Minimizuojančių normalizuotu ivertintų rodiklių suma $S_{-j}$} & 0,7066 & 0,6034 \\
\hline \multicolumn{4}{|c|}{ Projekto igyvendinimo varianto reikšmingumas $Q_{j}$} & 1,4299 & 1,4986 \\
\hline \multicolumn{4}{|c|}{ Projekto igyvendinimo varianto prioritetiškumas $P_{j}$} & 2 & 1 \\
\hline \multicolumn{4}{|c|}{ Projekto igyvendinimo varianto naudingumo laipsnis $N_{j}$} & $95,42 \%$ & $100 \%$ \\
\hline
\end{tabular}




\section{Loreta KELPŠIENÉ}

STATYBOS MODELIAVIMAS EKONOMINIO NUOSMUKIO APLINKOJE

Daktaro disertacija

Technologijos mokslai, statybos inžinerija (02T)

Loreta KELPŠIENÉ

CONSTRUCTION MODELLING IN ENVIRONMENT OF ECONOMIC RECESSION

Doctoral Dissertation

Technological Sciences,

Civil Engineering (02T)

201105 09. 11,25 sp. I. Tiražas 20 egz.

Vilniaus Gedimino technikos universiteto

leidykla „Technika",

Saulètekio al. 11, 10223 Vilnius,

http://leidykla.vgtu.It

Spausdino UAB "Ciklonas",

J. Jasinskio g. 15, 01111 Vilnius 